Universidade de São Paulo

Faculdade de Filosofia, Letras e Ciências Humanas

Departamento de Letras Clássicas e Vernáculas

Área de Literatura Portuguesa

Nathália Macri Nahas

Exploração, pobreza e humilhação na prosa de Carlos de Oliveira e Sophia de Mello Breyner Andresen 
Universidade de São Paulo

Faculdade de Filosofia, Letras e Ciências Humanas

Departamento de Letras Clássicas e Vernáculas

Área de Literatura Portuguesa

Nathália Macri Nahas

\section{Exploração, pobreza e humilhação na prosa de Carlos de Oliveira e Sophia de Mello Breyner Andresen}

Tese apresentada ao Programa de PósGraduação em Literatura Portuguesa, do Departamento de Letras Clássicas e Vernáculas da Faculdade de Filosofia Letras e Ciências Humanas - USP, para a obtenção do título de Doutora em Letras.

Orientadora: Prof ${ }^{\mathrm{a}}$. Dr ${ }^{\mathrm{a}}$. Paola Poma 
Autorizo a reprodução e divulgação total ou parcial deste trabalho, por qualquer meio convencional ou eletrônico, para fins de estudo e pesquisa, desde que citada a fonte.

Catalogação na Publicação

Serviço de Biblioteca e Documentação

Faculdade de Filosofia, Letras e Ciências Humanas da Universidade de São Paulo

Nahas, Nathália Macri

N153e Exploração, pobreza e humilhação na prosa de Carlos de Oliveira e Sophia de Mello Breyner Andresen / Nathália Macri Nahas; orientadora Paola Poma - São Paulo, 2021.

$280 \mathrm{f}$.

Tese (Doutorado)- Faculdade de Filosofia, Letras e Ciências Humanas da Universidade de Săo Paulo. Departamento de Letras Clássicas e Vernáculas. Área de concentraçăo: Literatura Portuguesa.

1. Literatura Portuguesa Contemporănea. 2. Carlos de Oliveira. 3. Sophia de Mello Breyner Andresen. I. Poma, Paola, orient. II. Titulo. 
NAHAS, Nathália Macri. Exploração, pobreza e humilhação na prosa de Carlos de Oliveira e Sophia de Mello Breyner Andresen. Tese apresentada ao programa de PósGraduação em Literatura Portuguesa da Faculdade de Filosofia, Letras e Ciências Humanas - FFLCH/USP - como parte dos requisitos para a obtenção do título de Doutora em Letras.

Aprovada em:

\section{Banca Examinadora}

Profa. Dra. Paola Poma (orientadora)

Julgamento:

Prof. Dr. Leonardo Garcia Santos Gandolfi Julgamento:

Profa. Dra. Marcia Valeria Zamboni Gobbi Julgamento:

Profa. Dra. Rejane Vecchia da Rocha e Silva Julgamento:
Instituição: USP

Assinatura:

Instituição: UNIFESP

Assinatura:

Instituição: UNESP/Araraquara

Assinatura:

Instituição: USP

Assinatura: 
Ao amado Pedro, que sempre confiou no meu olhar para a literatura e no meu trabalho e que sempre esteve ao meu lado 


\section{Agradecimentos}

O presente trabalho foi realizado com apoio da Coordenação de Aperfeiçoamento de Pessoal de Nível Superior - Brasil (CAPES), programa Demanda Socia.

À Profa. Dra. Paola Poma, pelo constante apoio e ensinamento, pelo afeto e pela amizade que me guiaram neste percurso tão importante.

Às Professoras Doutoras Marcia Valeria Zamboni Gobbi e Rejane Vecchia da Rocha e Silva e ao Prof. Dr. Leonardo Garcia Santos Gandolfi pela leitura atenta e pela atenção dedicadas em um momento decisivo.

Aos meus pais, à minha madrasta e à minha irmã, por acreditarem nas minhas escolhas e no meu trabalho e por me apoiarem sempre.

Aos meus amigos, que sempre me apoiaram nos momentos mais complexos dessa jornada.

Aos funcionários do Departamento de Letras Clássicas e Vernáculas da FFLCH/USP e da Biblioteca Florestam Fernandes, pelo auxílio sempre prestativo e atencioso.

E aos leitores e aos pesquisadores das obras de Carlos de Oliveira e de Sophia de Mello Breyner Andresen, por compartilharem interpretações e aprendizados. 


\section{Resumo}

NAHAS, Nathália Macri. Exploração, pobreza e humilhação na prosa de Carlos de Oliveira e Sophia de Mello Breyner Andresen. 2021. 280f. Tese (Doutoramento em Literatura Portuguesa) - Faculdade de Filosofia, Letras e Ciências Humanas, Universidade de São Paulo (USP), São Paulo, 2021.

O presente trabalho visa analisar comparativamente as questões sociais abordadas na prosa de Carlos de Oliveira e Sophia de Mello Breyner Andresen, especificamente de que modo ocorre a exploração entre as classes sociais no contexto capitalista português. A base da leitura dos aspectos socioeconômicos são os principais textos teóricos de Karl Marx e Friedrich Engels, como Manifesto Comunista e O Capital. Buscamos mostrar como a temática de cunho social desempenha um papel específico na obra de ambos os autores, tornando-se um elemento interno na elaboração literária ao lado de outros, como a estrutura dos textos e linguagem, considerando-se, sobretudo, que tanto Oliveira quanto Sophia Andresen escrevem durante o longo período da ditadura salazarista (1926-1974). Dialogamos com o conceito de Georg Lukács sobre grandes obras realistas, isto é, aquelas que criam uma unidade entre as aspirações subjetivas do homem e a realidade do mundo concreto no qual ele se insere. Propomos, assim, analisar o modo como os dois autores abordam as questões subjetivas do indivíduo ligadas às forças sócio-históricas que se impõem à sociedade capitalista. Desse modo, procuramos mostrar de que maneira eles trazem as implicações socioeconômicas desse sistema ao mesmo tempo em que transcendem a posição em que a crítica os coloca no amplo panorama da literatura portuguesa do século XX.

Palavras-chave: Carlos de Oliveira, Sophia de Mello Breyner Andresen, prosa portuguesa contemporânea, prosa política, Literatura Portuguesa. 


\begin{abstract}
NAHAS, Nathália Macri. Exploration, poverty and humiliation in the prose of Carlos de Oliveira and Sophia de Mello Breyner. 2021. 280f. Tese (Doutoramento em Literatura Portuguesa) - Faculdade de Filosofia, Letras e Ciências Humanas, Universidade de São Paulo (USP), São Paulo, 2021.

This work aims to comparatively analyze the social aspects broached in the prose of Carlos de Oliveira and Sophia de Mello Breyner Andresen, particularly how the exploitation between social classes occurs in the Portuguese capitalist context. The main theoretical texts of Karl Marx and Friedrich Engels, including The Communist Manifesto and The Capital, are the key readings for the socioeconomic aspects. We seek to demonstrate how the social theme plays a specific role in the work of both authors. It becomes an internal element in literary creation alongside others, such as the structure of texts and language, considering, above all, that both Oliveira as Sophia Andresen wrote during the long period of the Salazar dictatorship (1926-1974). We dialogue with Georg Lukács' concept of great realistic texts, those that create a unity between a man's subjective aspirations and the reality of the real world where he lives. We propose to analyze how both authors think the subjective matters of an individual related to the sociohistorical forces imposed on the capitalist society. Thus, we aim to show how they carry the socioeconomic implications of this system while transcending the position in which criticism places them in the panorama of 20th century Portuguese literature.
\end{abstract}

Keywords: Carlos de Oliveira, Sophia de Mello Breyner Andresen, Contemporary Portuguese prose, political prose, Portuguese literature 


\section{Sumário}

Introdução .010

1. O contexto modernista português e o surgimento de Carlos de Oliveira e Sophia de Mello

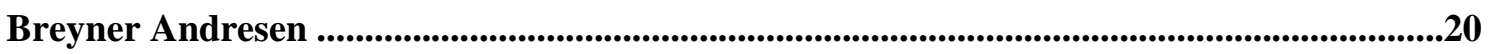

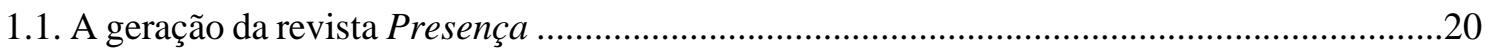

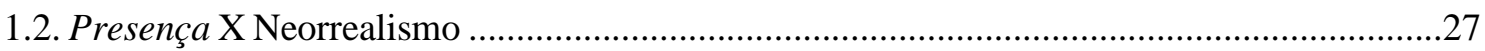

1.3. O pensamento neorrealista português e a literatura neo-humanista estrangeira do século

$\mathrm{XX}$

1.3.1. Carlos de Oliveira - a voz da Gândara ……………………………………..............43

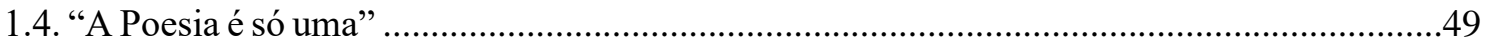

1.4.1. Sophia de Mello Breyner Andresen: a apreensão do real na poesia .............................51

2. O (neo) realismo humanista na prosa de Carlos de Oliveira ......................................................59

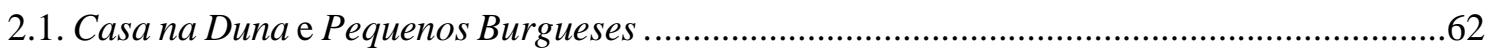

2.2. "De verão e de inverno - casa sem telha": a relação entre as classes sociais e a exploração

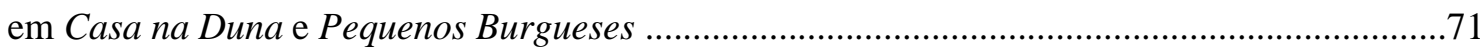

3. Finisterra ........................................................................................................................................................113

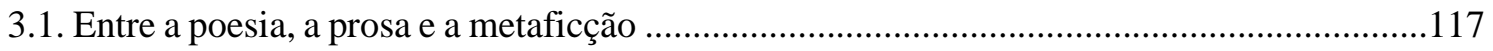

3.2. O deslocamento da linguagem e a reflexão sobre a representação do real ..............................132

3.3. Fim da terra, terra do fim: a alegoria da transformação de um sistema social ........................145

4. A prosa de Sophia de Mello Breyner Andresen ...........................................................................166

4.1. A concepção social andreseniana: o cristianismo em "O Jantar do Bispo".........................174

4.2. O superficial, a mentira e a maldade: o mundo das aparências em "A História da Gata

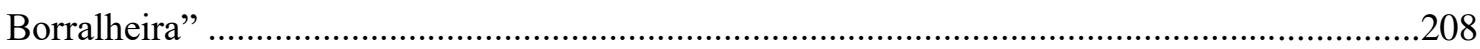

4.3. A imagem real $\mathrm{X}$ a imagem social: um retrato da riqueza e da pobreza em "O Retrato de

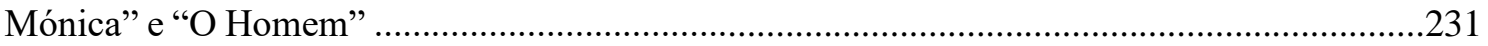

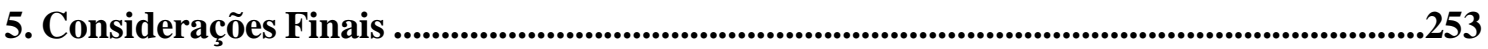

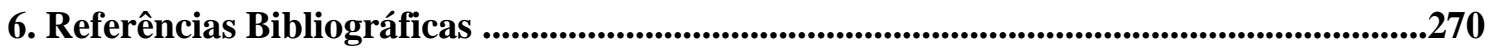




\section{Introdução}

A relação entre o mundo real - concreto, factível -, suas estruturas de poder sóciohistóricas e a literatura é uma temática bastante estudada pela crítica, mas que ainda suscita reflexões sobre o modo como elementos da realidade podem influenciar o desenvolvimento do projeto poético de um determinado autor implicado em seu contexto. O questionamento sobre tal influência sempre inquietou diversos pesquisadores e conosco não foi diferente. Nos estudos sobre a Literatura Portuguesa do século XX, percebemos que alguns autores traziam aspectos contextuais como elemento de elaboração de suas obras. Mais especificadamente, a leitura da obra de Sophia de Mello Breyner Andresen (1919-2004) chamou-nos atenção durante a análise de sua poesia considerada mais política, sobretudo em textos do Livro Sexto, publicado em 1962. Como resultado desse questionamento, entre 2011 e 2015 , desenvolvemos a pesquisa ${ }^{1}$ sobre o modo como o contexto ditatorial português relaciona-se com a obra Grades (1971), uma coletânea escolhida pela própria poeta de poemas considerados politicamente inspirados e engajados.

Nesse trabalho, verificamos que a relação entre aspectos sociais e a poesia andreseniana também era presente na sua obra ficcional. Buscamos, para a pesquisa atual, abordar os contos da autora a partir de uma perspectiva semelhante, mostrando como o elemento contextual português e a sua configuração socioeconômica foram fundidos a outros pontos do projeto literário de Sophia Andresen. Concomitantemente, no amplo panorama de autores portugueses contemporâneos, a obra de Carlos de Oliveira também nos suscitou o questionamento sobre o modo como o autor dialoga com a temática social, considerando que ele inicialmente surge associado ao movimento neorrealista, mas, durante seu itinerário literário, distancia-se dessa estética, seja pela publicação de seu último romance, Finisterra (1978), seja pelo intenso trabalho de reconstituição e reescrita de romances e poesia que engendrou. Estabelecemos, então, que o projeto da presente pesquisa seria baseado em uma leitura que aproximasse a obra andreseniana e a de Oliveira sob o viés social, especificamente nas relações de classe e na exploração do homem por seus semelhantes no contexto capitalista português.

\footnotetext{
${ }^{1}$ NAHAS, Nathália. Grades: uma leitura do projeto po-ético de Sophia de Mello Breyner Andresen. São Paulo, 2015. 164 p. Dissertação (Literatura Portuguesa) - Faculdade de Filosofia, Letras e Ciências Humanas, Universidade de São Paulo.
} 
Sabendo, entretanto, que a relação entre literatura e sociedade é amplamente discutida e, por vezes, criticada negativamente, buscamos nos apoiar em pensadores que se aprofundaram nesse aspecto como um modo válido de análise literária. Em seu artigo "Crítica e Sociologia" (2014, p. 13), Antonio Candido observa que a literatura de cunho social tem sido foco de análise da crítica de formas distintas; no passado, o condicionamento social de uma obra era visto como aspecto-chave para a sua compreensão, porém tal perspectiva "foi rebaixada como falha de visão" posteriormente, e, nos dias atuais, começou-se a fazer estudos a partir de um meio-termo. De acordo com o crítico, "seria o caso de dizer, com ar de paradoxo, que estamos avaliando melhor o vínculo entre a obra e o ambiente, após termos chegado à conclusão de que a análise estética precede considerações de outra ordem" (2014, p. 13):

\begin{abstract}
Antes procurava-se mostrar que o valor e o significado de uma obra dependiam de ela exprimir ou não certo aspecto da realidade, e que este aspecto constituía o que ela tinha de essencial. Depois, chegou-se à posição oposta, procurando-se mostrar que a matéria de uma obra é secundária, e que a sua importância deriva das operações formais postas em jogo, conferindo-lhe uma peculiaridade que a torna de fato independente de quaisquer condicionamentos, sobretudo social, considerado inoperante como elemento de compreensão. (Ibid.)
\end{abstract}

Segundo o autor, ambos os posicionamentos, quase extremos, foram ultrapassados, e a crítica atual procura estabelecer uma visão diferenciada, sabendo que "a integridade da obra não permite adotar nenhuma dessas visões dissociadas" (Ibid.). Para a sua compreensão, torna-se necessária a fusão de texto e contexto "numa interpretação dialeticamente íntegra" (Ibid.) que contemple tanto a perspectiva que buscava a explicação por meio de fatores externos quanto a análise norteada pela convicção "de que a estrutura é virtualmente independente" (Ibid., p. 13-14). Desse modo, o elemento social não é tomado externamente como referência temática ou enquadramento contextual, mas, sim, como "fator da própria constituição artística" (Ibid., p. 14).

A crítica literária busca, assim, analisar o modo como o fator social - externo ou contextual - atua não como causa nem significado, mas, sim, como elemento que desempenha um papel específico na constituição da estrutura textual, tornando-se interno e unindo-se a outros aspectos, como um "todo indissolúvel” (Ibid., p. 15), para a realização do valor estético (expressão utilizada por Georg Lukács). Dessa maneira, elaboramos a hipótese de que tanto Carlos de Oliveira quanto Sophia de Mello Breyner 
Andresen trazem em sua obra ficcional o elemento real e concreto de seu contexto como mais um dos pilares de seus projetos literários. Consideramos que a escrita de ambos os autores é elaborada majoritariamente durante o período da ditatura comandada por António de Oliveira Salazar (1889-1970), o chamado Estado Novo (1926-1974), o que implica a abordagem de uma nação estagnada tanto política quanto economicamente. $\mathrm{O}$ capitalismo industrial avança timidamente no início do século XX, mas Portugal mantinha-se essencialmente como uma economia agrária, desenvolvendo-se a partir de produtos tradicionais - como cereais, vinho e azeite, o que não permitia ao país uma maior independência em relação a outras nações europeias nem uma forte desenvoltura econômica. A organização do setor rural e de suas estruturas é uma das principais bases de crítica social que aparecem nos textos de Oliveira e também de Sophia.

Para criarmos uma proposição crítica acerca dos autores, procuramos aprofundarnos nos escritos de Lukács sobre estética e literatura, com especial atenção às análises do seu conceito de obras realistas, isto é, aquelas que fundem o âmbito contextual como mais um elemento da elaboração da obra, criando uma unidade entre a interioridade e a exterioridade, entre aspirações de cunho subjetivo e particular e a realidade do mundo objetivo, como explica o pensador Nicolas Tertulian (1980, p. 51-53). Lukács desenvolve a ideia de que um escritor realista - o termo abrange escritores além da corrente literária do Realismo, do século XIX - consegue abordar o indivíduo e sua subjetividade unida ao todo social, isto é, as forças sócio-históricas que se impõem à sociedade, criando uma totalidade entre o contexto objetivo e a existência do homem.

Procuramos, em seguida, estabelecer quais seriam os textos analisados em nosso estudo, considerando que Sophia Andresen e Carlos de Oliveira, apesar de serem contemporâneos, surgiram a partir de movimentos literários distintos, o que será aprofundado no capítulo 1 deste trabalho. O estudo da obra de Oliveira mostrou-se desde o início um significativo desafio no que tange à escolha do corpus para a pesquisa. Precisamos considerar a relação do autor com o movimento do Neorrealismo português, que surge a partir de ideias opostas sobre a literatura e a sua função como arte expressas pela geração de escritores ligados à revista Presença (1927 a 1940). Entretanto, a aproximação do autor com o grupo neorrealista sofre um distanciamento ao longo da sua trajetória literária.

Vamos, inicialmente, mostrar de que modo a estética neorrealista esteve presente nas obras estudadas, mas indicaremos que, em sua própria revisão, o autor atenua alguns aspectos formais e de conteúdo de sua ficção considerada neorrealista, chegando à 
publicação de Finisterra, que apresenta uma ruptura na linguagem e na estrutura até então presente nos livros anteriores. Desse modo, estabelecemos como corpus dois romances em que se observa a influência do Neorrealismo, Casa na Duna (1943) e Pequenos Burgueses (1948), e o último romance, Finisterra. A partir dessa leitura, dialogaremos com os princípios realistas de Lukács, indicando como Oliveira transcende as premissas do Neorrealismo, mesmo que mantenha a abordagem das relações de classe na sociedade portuguesa rural como foco de seus textos.

Em diálogo com a obra de Carlos de Oliveira, trazemos o corpus de Sophia Andresen, que surge ligada à publicação Cadernos de Poesia (1940 a 1953), mas constitui-se como uma autora ageracional ao longo de sua trajetória literária. Seus contos relacionam-se de forma intensa com os elementos de sua poesia, como os ideais gregos de justiça e equilíbrio, buscando na realidade a sua construção e a sua perspectiva crítica. A relação do homem com o mundo, os deuses e os seus semelhantes é essencialmente a base do desenvolvimento ficcional andreseniano, o que implica seus contos em um viés político, ideia defendida pela escritora em seus ensaios, mais especificamente em "Poesia e Revolução" (ANDRESEN, 1977).

Em sua constante "perseguição do real" (Idem, 2011, p. 841), ela nos diz que a poesia - e estendemos a concepção de poesia à sua prosa - "é a mais funda implicação do homem no real" e, portanto, "é necessariamente política e fundamento da política" (Idem, 1977, p. 77). Temos de considerar que, entre os fundamentos clássicos que estão no projeto da autora, há também o ideal de democracia, algo completamente renunciado em um contexto de ditadura como era o de Portugal no período. Para a análise, selecionamos quatro contos: "O Jantar do Bispo", "O Retrato de Mónica" e "O Homem", pertencentes aos Contos Exemplares (1962), e "A História da Gata Borralheira", de Histórias da Terra e do Mar (1984).

A escolha dos contos de Sophia Andresen foi norteada pela presença de aspectos considerados mais politizados que aparecem em consonância com outros elementos fundadores de sua obra, como a influência de sua formação cristã e a sua leitura do mundo clássico. Nesse sentido, pareceu-nos essencial a escolha majoritária de contos provenientes do livro Contos Exemplares, que é publicado no mesmo período que Livro Sexto. Em uma carta à autora, Jorge de Sena observa que este é um momento em que ela apresenta "uma admirável renovação da sua identidade de poeta sempre fiel a si próprio" (ANDRESEN; SENA, p. 2010, p. 70). Já o conto "A História da Gata Borralheira" destaca-se na obra Histórias da Terra e do Mar pelo seu agudo senso crítico em relação 
às estruturas de classe presentes na sociedade, sendo essa a principal razão para nossa seleção como parte do corpus.

No processo de análise dos textos selecionados de ambos os autores, dialogamos com textos teóricos de pensadores que contemplaram uma perspectiva materialistahistórica da literatura, tendo como principal nome Georg Lukács. Essa decisão decorre do fato de Carlos de Oliveira e de Sophia Andresen se relacionarem, ao longo do seu itinerário literário, com elementos da ideologia marxista. Devemos ressaltar que Oliveira surge no movimento Neorrealista, que dialoga abertamente com as teorias de Karl Marx e Friendrich Engels, além de outros teóricos de base marxista que elaboraram teses sobre literatura, cultura e estética, como abordaremos no capítulo 1. Sophia, por sua vez, tem uma relação também de cunho político com o Partido Socialista Português, tendo sido inclusive deputada na Assembleia Constituinte em 1975.

A partir dessas ideias, este trabalho divide-se em quatro capítulos e as considerações finais. No primeiro capítulo, analisaremos o contexto modernista português desde a primeira metade do século XX, a partir da publicação Orpheu (1915). Desse modo, poderemos localizar de que forma o movimento Neorrealista surge, sob a égide de uma orientação marxista, como uma oposição aos valores da revista Presença (1927-1940), a qual ressalta a importância da singularidade na criação artística. Com o princípio de que a arte é suscitada pela individualidade do artista, essa publicação gerou uma série de críticas contrárias, dentre elas noções referentes à abstenção do papel do escritor diante do conturbado contexto sociopolítico europeu e português das décadas de 1930 e 1940 e a uma perspectiva de que a publicação era contra os modernos da geração de Orpheu.

Nesse capítulo, dialogamos com críticos, como Eduardo Lourenço, Fernando Guimarães, Carlos Reis, Rosa Maria Martelo, Mário Dionísio e Alexandre Pinheiros Torres, que explicam o surgimento da Presença e a celeuma crítica que dá origem ao Neorrealismo. Ainda trazemos a contextualização de Carlos de Oliveira diante desse movimento e seu lugar na Literatura Portuguesa do século XX. O capítulo prossegue com o aparecimento dos Cadernos de Poesia (1940-1954), sob o lema "A Poesia é só uma" que buscava um apaziguamento entre as tensões de presencistas e neorrealistas. É em tal contexto que Sophia de Mello Breyner Andresen surge, fazendo sua primeira publicação no primeiro fascículo dos Cadernos. Buscaremos, assim, também inserir a autora no contexto literário português dos anos 1940. 
O segundo capítulo introduzirá a análise sobre as obras de Carlos de Oliveira, Casa na Duna e Pequenos Burgueses. Iniciaremos os estudos acerca do singular Neorrelismo expresso pelo autor, cujo itinerário poético fora fortemente marcado pela sua vivência na Gândara portuguesa. Mostraremos que tal região é algo além de uma paisagem para a sua obra, sendo a base do pensamento, de imagens e de personagens, isto é, um dos elementos - dentre as questões de classe abordadas - que impõem sua força sobre os mais carentes, assim como o poder econômico. Indicaremos também o modo como a crítica literária observou Oliveira de forma não ortodoxa em relação aos preceitos neorrealistas, ideia elaborada em parte pelo fato de o autor abordar em suas obras não somente personagens de classes sociais mais carentes como também aqueles que têm o poder de explorar seus semelhantes.

Para a explicação do estilo particular de Carlos de Oliveira abordar o Neorrealismo, dialogaremos com Alexandre Pinheiro Torres, Vítor Viçoso, Rosa Maria Martelo, Carlos Reis, Osvaldo Silvestre, Gonçalo Duarte, entre outros nomes. Em relação à analise dos elementos sociais no corpus oliveiriano, trazemos reflexões de Maria Aparecida Santili e Lélia Duarte, além de importantes observações de Mário Dionísio. O aporte teórico em torno das relações de classe estabelecidas nos romances é pautado nos escritos de Marx e Engels, como Manifesto Comunista, O Capital - livro I, entre outros. Devemos ressaltar que também dialogaremos ao longo do capítulo com os ensaios escritos por Carlos de Oliveira, sobretudo aqueles publicados na obra O Aprendiz de Feiticeiro (1971).

O terceiro capítulo abordará a singular obra Finisterra, procurando mostrar que, de um lado, a linguagem elaborada é uma ruptura em relação aos romances anteriores de Carlos de Oliveira, muito próximos da estética neorrealista. De outro lado, mostraremos que, apesar dessa inovação, a temática desse romance mantém os questionamentos propostos no projeto ficcional oliveiriano, trazendo o conflito da perda da propriedade privada e o colapso do núcleo familiar pertencente à classe dominante. O livro apresentase como um ir e vir entre a narrativa e a poética, porém não abandona as demandas críticas do autor diante da sociedade de classes. A abordagem dessa obra passará, inicialmente, a uma reflexão sobre a fronteira ténue entre gêneros, a prosa e a poesia, e também nos suscitará uma consideração sobre a metaficção, uma vez que o romance é visto pela crítica - como citaremos Manuel Gusmão, entre outros - como uma extensa e concentrada figuração da poética do autor. Verificaremos a condição de "prosa poética" da obra aos 
olhos dos críticos e exploraremos a conceituação de "metaficção" a partir da leitura de Linda Hutcheon.

Ainda nesse capítulo, proporemos a análise sobre a linguagem particular de Finisterra e a constante busca pela representação do real que move as suas personagens. Para isso, consideraremos a hipótese da crítica - como Rosa Maria Martelo - de que a obra é uma revisitação do primeiro romance do autor, Casa na Duna, porém que se apresenta com uma inovação na linguagem que transita entre o ficcional e o poético. Buscaremos dialogar com as ideias de Roland Barthes sobre a linguagem literária, propondo que esta rompe com a linguagem gregária, deslocando-se, assim, da expressão obrigatória de um código no qual se inscreve o poder. Nesse sentido, a elaboração da linguagem em Finisterra compreende uma utilização que está fora do poder, em movimento e revolução permanente.

A continuação do terceiro capítulo contemplará a questão da transformação de um sistema social que implica o declínio da família nuclear da obra. Analisaremos o desmantelamento da propriedade privada e a destruição do ciclo geracional familiar em torno das teorias de Marx e, principalmente, Engels, na sua obra A Origem da Família, da Propriedade Privada e do Estado, que nos servirá como principal base de crítica à proposta de Carlos de Oliveira de abordar a transformação destrutiva inscrita no próprio sistema econômico capitalista, que se autoalimenta das crises de suas próprias estruturaschave, como a família e a propriedade privada. Será abordado o conflito do sistema patriarcal dada a impossibilidade de essa família manter o ciclo de gerações, o que compromete diretamente a transmissão dos bens desse núcleo. Além disso, discutiremos o papel da mulher no romance, vista como um "mal necessário", uma intrusa que adentra os grupos familiares e, muitas vezes, contamina-os com a sua infertilidade. Desse modo, procuraremos mostrar que Finisterra se organiza como uma alegoria da transformação de um sistema econômico que, em seu próprio mecanismo, devora metaforicamente desde pequenos a grandes proprietários que, de algum modo, não conseguem acompanhar as mudanças estruturais da sociedade. É um sistema que se autoalimenta de suas próprias bases e estruturas.

O quarto capítulo será dedicado à obra ficcional de Sophia de Mello Breyner Andresen. Após uma breve reflexão sobre o modo de constituição de Contos Exemplares e Histórias da Terra e do Mar, buscaremos mostrar de que maneira a autora desenvolve um projeto poético livre, ou ageracional, isto é, com autonomia em relação à sua filiação literária aos Cadernos de Poesia. Partiremos da análise de "O Jantar do Bispo" e a criação 
de alegorias que representam o bem e o mal em um discurso que dialoga com o viés cristão da escritora para criar um debate político acerca das relações de poder instituídas pelo capital e naturalizadas como legítimas na sociedade de classe. O conto revela um caráter de "des-alheamento" diante da alienação sobre a consciência de classe presente no contexto rural onde se desenvolve a trama.

O foco da leitura centra-se no conflito entre as personagens Dono da Casa e o pároco de Varzim, que representam as classes sociais opostas daquela região. Utilizaremos novamente textos teóricos de Marx e Engels para trabalhar a questão de consciência e luta de classes, em diálogo com preceitos cristão de bondade, compaixão e amor ao próximo. Será discutido também o modo como o conceito de "hegemonia", de Antonio Gramsci se relaciona à noção de subjugação dos grupos desfavorecidos socioeconomicamente e de que forma podemos associá-lo à perspectiva da autora em seu conto, que se apresenta a partir de uma expressiva crítica à sociedade de classes do contexto português dos anos 1960 feita por meio da influência de valores clássicos de harmonia e justiça e de ideais cristãos, pilares nessa poética.

Em seguida, analisaremos a perspectiva de Sophia Andresen no que tange ao mundo das aparências e da superficialidade presentes na realidade das classes dominantes no conto "A História da Gata Borralheira". Observaremos como uma jovem, que tem uma vida livre, porém simples, encanta-se com os luxos e com o poder do mundo das pessoas abastadas, decidindo deixar sua vivência de menina pobre para se entregar às vantagens e à beleza do mundo aristocrático e burguês. $\mathrm{O}$ conto faz uma releitura singular do conto infantil da Cinderela, que apresenta a superação da humilhação e da exploração a partir da bondade. Já no conto andreseniano, a nossa borralheira representa uma versão híbrida da história infantil, pois permite uma interpretação crítica acerca do conflito de classes, por meio do viés da alienação. Buscaremos mostrar de que modo a personagem principal, vinda de um grupo desfavorecido, pretende inserir-se no belo e luxuoso mundo dos poderosos economicamente a qualquer custo.

A leitura será feita a partir da análise de críticos da Literatura Portuguesa como Paola Poma, Clara Rocha, Maria da Conceição Coelho e Maria Teresa Azinheira, que elaboraram interpretações sobre este conto. Além disso, dialogaremos com a história infantil Cinderela e a sua moral, procurando mostrar de que modo Lúcia, a borralheira de Sophia Andresen, deixava-se iludir pelas aparências e pela superficialidade da classe dominante, que, por sua vez, menosprezavam-na, mostrando que ela não pertencia àquele mundo. Sobre a atração pelo luxo e pela beleza das classes dominantes, dialogaremos 
com Pierre Bourdieu, expressando que os diversos estilos de vida das classes sociais são a condição de existência de cada grupo na sociedade. Essa ideia auxilia-nos na compreensão sobre a posição da protagonista como uma garota humilde em um baile da alta sociedade. O conto constrói-se, pois, a partir de um diálogo com a moral da história infantil, porém traz uma personagem dividida entre a riqueza e a pobreza, do mesmo modo como a sociedade apresenta uma polarização entre as classes socioeconômicas.

A última parte do capítulo abrange a análise dos contos "O Retrato de Mónica" e "O Homem", mantendo a mesma perspectiva da leitura de textos críticos à sociedade de classes estabelecida no sistema capitalista. Em "O Retrato de Mónica", partiremos da pesquisa sobre o uso da ironia pela narradora, que traz características da protagonista de modo crítico em relação a conceitos prezados na obra andreseniana, como o simples e o natural. Mostraremos como a posição da autora é trabalhada a partir da acentuada crítica à ostentação, ao luxo, à alienação, à sociabilidade política e ao poder de uma mulher, uma socialite, que manipula pessoas e situações a seu favor, sempre buscando permanecer em boas relações com o "Príncipe deste Mundo", uma personagem alegórica que faz referência a Salazar.

Em “O Homem”, Sophia Andresen recupera a relação de ideais cristãos na aguda crítica à invisibilidade das pessoas pobres, sobretudo aquelas em condição de rua. A partir do contraste entre a pressa com que uma multidão andava e a lentidão de um homem carente que tentava locomover-se com uma criança no colo, a escritora mostra seu posicionamento sobre as relações entre as classes e, consequentemente, a relação entre os homens, pelo viés do sofrimento de Jesus na sua crucificação. O sentimento de abandono de Cristo perante a situação é uma analogia àquilo que o homem pobre sente, sendo ignorado por todos que por ele passam. Buscaremos trazer na análise teóricos que pesquisam a invisibilidade social dos pobres, a cegueira social, a reificação de indivíduos carentes e também a aporofobia, conceito elaborado pela socióloga Adela Cortina que define o rechaço e o desprezo por pessoas em situação de carência.

Dessa forma, neste trabalho, procuraremos demonstrar de que modo a escrita crítica de Carlos de Oliveira e a de Sophia Andresen dialoga com as questões de classe na sociedade portuguesa e com a exploração inerente ao sistema econômico no qual estão inseridos. Analisaremos como os dois escritores relacionam-se com a ideia de inserir elementos do mundo real - factível - como parte de suas obras literárias e de que maneira isso nos possibilita a fazer uma leitura que os aproxima conforme as noções de Georg Lukács sobre a grande literatura realista, isto é, aquela que expressa experiências 
singulares do homem implicadas nas regras sócio-históricas que determinam a natureza do mundo concreto. Na visão do pensador húngaro, essa literatura pode levar à desalienação do contexto capitalista, promovendo o contato do leitor com a totalidade dos elementos do mundo objetivo, como as lutas cotidianas entre classes, a subjugação de homens por seus semelhantes, o caos e a miséria que são resultantes desse sistema. Como Sophia diz em sua terceira "Arte Poética": "Se em frente do esplendor do mundo nos alegrarmos com paixão também em frente ao sofrimento do mundo nos revoltamos com paixão" (2011, p. 842), vamos mostrar de que modo ela e Oliveira desnudam as mazelas e as carências da sociedade do período salazarista ao mesmo tempo em que transcendem a posição em que a crítica os coloca no panorama da literatura portuguesa do século XX. 


\section{O contexto modernista português e o surgimento de Carlos de Oliveira e Sophia de} Mello Breyner Andresen

\subsection{A geração da revista Presença}

Nas três primeiras décadas do século XX, Portugal observa em seu cenário literário movimentos profícuos que promovem mudanças muito significativas e marcantes no pensamento artístico. Os anos 1900 começavam com um prolongamento, no campo da literatura, de expressões artísticas oitocentistas, como observa José Seabra Pereira $^{2}$ (2003, p. 419): os autores e o estilo se estendiam ligados a um resquício realista e à expressão do Neorromantismo.

A onda das vanguardas do início do século, porém, atinge a literatura europeia de forma intensa, e Portugal também vai verificar um brusco rompimento com a arte associada ao século XIX, o que Seabra Pereira nomeia de "erupção modernista"33 (Ibid.). Fernando Pessoa e Mário de Sá-Carneiro, que já haviam colaborado com a revista A Águia (1910-1932), instrumento principal do saudosismo de Teixeira de Pascoaes, vão se colocar em oposição a esse movimento e passam a buscar, a partir da influência vanguardista, "um tom audaz e requintado que faltava à poesia saudosista"4 (Ibid., p. 420).

Em 1912, ocorre a publicação de Princípio, a primeira coletânea de Sá-Carneiro, enquanto Fernando Pessoa apresenta suas ideias críticas sobre a moderna poesia portuguesa nos seus artigos publicados em A Águia. No entanto, conforme observam Carlos Reis e António Apolinário Lourenço, esses textos "não podem ser ainda considerados modernistas" (2015, p. 18). A ruptura com o saudosismo, segundo os autores, acontece de forma gradual e em 1914 já está consolidada. Pessoa e Sá-Carneiro mobilizam-se diante de ideias de publicar uma revista que traga os novos expoentes da literatura portuguesa, o que é estimulado pelas manifestações das vanguardas europeias, informação “canalizada pela correspondência de Mário de Sá-Carneiro” (Ibid.).

Os projetos de Pessoa e Sá-Carneiro não chegam a ser executados, porém, no ano seguinte, Luís de Montalvor - nome artístico de Luís da Silva Ramos - vem do Brasil e apresenta o projeto de uma revista que concentrasse as tendências artísticas e literárias do

\footnotetext{
${ }^{2}$ In: CASTRO, F.; REIS, C.; LOPES, O.; MARINHO, M., 2003.

${ }^{3}$ Ibidem.

${ }^{4}$ Ibidem.
} 
período, uma publicação que trouxesse certa convergência entre os novos autores dos dois países lusófonos. Essa ideia vem ao encontro daquelas cultivadas pelos amigos Pessoa e Sá-Carneiro, e este tinha "a possibilidade material de realizar a revista". 5 Nasce, assim, a revista Orpheu, a qual condensa o primeiro momento do Modernismo em Portugal, rompendo com o "arrastamento cultural e literário dos padrões oitocentistas [...]" 6 (PEREIRA, 2003, p. 419).

A revista propunha criar uma arte cosmopolita "no espaço e no tempo" - conforme observa Fernando Pessoa ${ }^{7}$-, em assonância com as vanguardas europeias, e dela foram publicados dois números: março e junho de $1915^{8}$. Sua rápida existência não ofuscou seu efeito no contexto artístico português. "Feitos, em parte, para irritar o burguês, para escandalizar, estes dois números alcançaram o fim proposto, tornando-se alvo das troças dos jornais; mas a empresa não pôde prosseguir por falta de dinheiro", segundo as observações de Seabra Pereira $^{9}$ (Ibid., p. 509). Sua publicação promove a circulação de novas tendências literárias e acaba por reunir os nomes em torno do Modernismo português.

Seabra Pereira observa que, ainda que trouxesse "contaminações programáticas e temático-formais com elementos decadentistas ou simbolistas, sobretudo, e neorromânticos", Orpheu inaugura um cenário inovador para o âmbito literário:

O ambiente sugestionador da possibilidade de ruptura com a 'cultura oficial' e de subversão do funcionamento institucional da literatura, bem como da necessidade de inconformismo nos idiolectos de cada escritor, é um património inestimável do Modernismo orfaico, que catalisou, apesar de tudo, fenómenos de tanto interesse como a nova configuração [...] de revistas que sucederam a Orpheu - Centauro (1916), Exílio (1916), Portugal Futurista (1917), Contemporânea ${ }^{10}$

\footnotetext{
${ }^{5}$ Fernando Pessoa, em um fragmento datilografado, explica as circunstâncias da criação de Orpheu. Posteriormente, esse texto é publicado na Colóquio, Artes e Letras, no 48, abril, 1968, e com variantes na Nova Renascença, n2, 1981, conforme cita José Augusto Seabra em "Genealogia e significado de Orpheu". In: CASTRO, F.; REIS, C.; LOPES, O.; MARINHO, M., 2003, p. 426.

${ }^{6}$ In: CASTRO, F.; REIS, C.; LOPES, O.; MARINHO, M., 2003.

7 PESSOA, F. “O que quer Orpheu?". In: PESSOA, F. 1966, p. 113.

${ }^{8}$ A direção do primeiro número traz a associação do poeta brasileiro Ronald de Carvalho, e nomes como Almada Negreiros, Alfredo Guisado e Armando Cortes-Rodrigues são associados à publicação. $O$ segundo número é dirigido por Fernando Pessoa e Mário de Sá-Carneiro.

${ }^{9}$ In: CASTRO, F.; REIS, C.; LOPES, O.; MARINHO, M., 2003.

${ }^{10}$ Carlos Reis e António Apolinário Lourenço reconhecem as revistas Centauro e Exílio de forma menos enfática que José Seabra Pereira. Eles indicam a presença de publicações dos colaboradores da Orpheu, porém afirmam que são publicações "muito mais limitadas" e "circunscreviam-se esteticamente a um decadentismo relativamente convencional" (REIS, C.; LOURENÇO, A., 2015, p. 21). Já a revista Contemporânea, dirigida por José Pacheco, autor da capa da primeira Orpheu, é descrita por Reis e Lourenço como não estritamente vanguardista, pois acolheu nomes do Simbolismo histórico e do Saudosismo. Ainda assim, teve como colaboradores diversos "órficos", incluindo a presença de Fernando
} 
(1922-1926), Bizâncio (1923-1924), Athena (1924-1925) [.... ${ }^{11}$ (2003, p. 421).

Torna-se, assim, muito abrangente o alcance histórico-literário da revista e, naturalmente, sua influência no cenário artístico das primeiras décadas do século XX em Portugal.

O cenário pós-Orpheu promoveu a publicação, nos anos 1920, de diversas revistas, porém, curiosamente, muitas se ligavam a uma tradição literária relativa ao Romantismo, como ocorreu com o periódico A Tradição, que circulou em 1920. Na esteira mais direta do impacto de Orpheu, Carlos Reis e António Lourenço destacam a publicação de Athena, em 1924, cuja direção foi de Fernando Pessoa e Ruy Vaz. Esta é, para os autores, uma "herdeira espiritual de Orpheu" (2015, p, 23). Nos cinco volumes veiculados, são publicados textos de Álvaro de Campos ("Apontamentos para uma Estética não Aristotélica"), Ricardo Reis ("Livro I" das suas Odes), Alberto Caeiro (seleção de alguns poemas), “Os Últimos Poemas”, de Sá-Carneiro, "Pierrot e Arlequim”, de Almada Negreiros, entre outros.

Em 1927, surge a Presença, revista iniciada pelos então estudantes José Régio, João Gaspar Simões e Branquinho da Fonseca e, posteriormente, dirigida também por Adolfo Casais Monteiro. O perfil da publicação delineava-se a partir da busca de um sujeito biográfico, revelando conteúdos em que a presença do indivíduo era fortemente marcada. O periódico teve uma extensão notável: 56 números foram publicados entre 1927 e 1940. Um aspecto importante, ressalta Fernando Guimarães, é o fato de a revista trazer, além dos textos propriamente literários - como poesia, contos, teatros, trechos de romances -, artigos que propunham uma reflexão crítica e teórica acerca da literatura e do papel do escritor. ${ }^{12}$

Logo em seu primeiro número, a Presença traz um artigo de José Régio chamado de "Literatura Viva", o qual expõe noções essenciais para a concepção poética e artística proposta pela revista: a arte relativa à originalidade e à sinceridade. Diz Régio: "Em Arte, é vivo tudo o que é original” (apud GUIMARÃES, 1969, p. 13), e tal originalidade proviria "da parte mais virgem, mais verdadeira e mais íntima duma personalidade artística" (Ibid.). Assim, a obra viva é aquela que trazia a verdade sobre a personalidade

\footnotetext{
Pessoa, que publicou "Mar Português" e o artigo "António Botto e o Ideal Estético em Portugal" (REIS, C.; LOURENÇO, A., 2015, p. 22),

11 In: CASTRO, F.; REIS, C.; LOPES, O.; MARINHO, M., 2003.

12 In: Ibid., p. 13.
} 
do autor, por isso a noção de sinceridade, a qual se torna "fulcral para uma definição que se pretende conseguir de uma poética presencista". ${ }^{13}$

Régio, conforme observa Guimarães (1969, pp. 14-15), olhava “desconfiado” para a literatura de sua época, afirmando que essa mentalidade - da sinceridade e originalidade - faltava aos artistas do período, assim como originalidade. Sobre os autores daquele período ao qual ele se referia, podemos considerar a esteira de criação modernista pósOrpheu e as manifestações futuristas, por exemplo. Em seu artigo, o autor ainda elabora a ideia de que a literatura está inserida em uma tradição, ou seja, é preciso considerar seu desenvolvimento no tempo. Assim, como explica Guimarães, “[...] é sempre possível entrever uma continuidade que lhe é dada pelo facto de nela haver algo de essencial ou constituinte". ${ }^{14}$ Por essa razão, para Régio, é natural que os artistas resgatem a tradição literária, seguindo o exemplo dos grandes artistas de outrora.

Esse olhar para o passado se configura como um traço recorrente dos presencistas, os quais "não excluem da modernidade a possibilidade de ela se reportar a uma tradição que acabaria por se renovar. E, sendo assim, a modernidade não teria de se confundir, necessariamente, com os movimentos de vanguarda" ". Essa "desconfiança” de Régio em relação às vanguardas pode ser compreendida a partir de outra citação que faz acerca das escolas literárias:

O espírito modernista é [...] assimilável ao espírito romântico tomando os dois termos na sua mais ampla acção. E o próprio romantismo como escola, o classicismo, o gongorismo, o realismo, o simbolismo, o futurismo, o cubismo, o dadaísmo, o expressionismo, o ultrarrealismo e todas as espécies de ismos aparecidos ou a aparecer são, enquanto escolas estritamente definidas e portanto reduzidas pela sua própria definição restrita, antimodernistas. Embora os seus criadores sejam dos modernistas mais completos (apud GUIMARÃES, 1969, p. 13).

Uma visão prática dessa afirmação pode ser verificada a partir de suas palavras sobre Teixeira de Pascoaes, que seria grande "quando escuta seu génio: quando se não propõe chefiar uma escola ou demonstrar e expor o Saudosismo fazendo versos" (Ibid., p. 17) - ou seja, Régio acredita que, quando um objeto artístico ou a própria noção de arte está sob a definição de uma escola, sob a égide de um movimento, ela perde sua originalidade, ela se torna restrita, uma vez que, ao obedecer ao "standard" de uma

\footnotetext{
${ }^{13}$ In: CASTRO, F.; REIS, C.; LOPES, O.; MARINHO, M., 2003, v. 07, p. 12.

${ }^{14}$ In: Ibid., p. 13.

${ }^{15}$ In: Ibidem.
} 
tendência, perde o artista a expressão de sua personalidade, sua exposição não se mantém sincera.

A Presença, dessa maneira, configura-se a partir de uma concepção que ressalta a importância da singularidade na criação artística, delineando um caminho muito estreito entre a individualidade e a arte, a qual deveria ser resultado de uma originalidade, e não de um padrão estético. Régio afirma que "a arte é expressão, sugestão, ou representação do mundo (interior e exterior) através dum temperamento próprio, dum conhecimento pessoal, duma alma individualizada" (apud GUIMARÃES, 1969, p. 16). Ela seria, então, fruto e nova existência da vivência pessoal do artista, que seria um homem superior por sua inteligência, imaginação e sensibilidade.

Nesse aspecto, há uma consideração interessante. Fernando Guimarães observa que o caminho seguido por José Régio de relacionar intelectualização à sensibilidade já fora trilhado por Fernando Pessoa, porém a partir de pressupostos distintos. Para Régio, o Classicismo representa um momento em que o artista soube unir as "faculdades criadoras", promovendo uma consonância entre intelecto e emocionalização, ou seja, um equilíbrio. Na sua visão, seria pela inteligência "que o artista refere às afecções da sensibilidade" 16 que se voltam "em afecções do seu pensamento" ${ }^{17}$. Já Pessoa, embora articulasse a intelectualidade ao sensível, não buscava um equilíbrio, e sim uma dissipação deste, como se verifica, por exemplo, no processo de heteronímia.

Segundo o autor dos Poemas de Deus e do Diabo, o que há de moderno na arte advém da própria individualidade, que deve vir ligada ao exercício intelectual, possuindo, assim, três características essenciais: "Tendência vincada e confessa para a multiplicidade de personalidade. Tendência para o abandono às forças do sub-consciente, e simultaneamente para o domínio da intelectualidade na Arte. Tendência para a transposição, isto é: para a expressão paradoxal das emoções e dos sentimentos” (apud MACEDO, 2010, p. 06).

Outro presencista que se aprofunda na concepção poética baseada na individualidade é João Gaspar Simões. No seu ensaio "Duas Formas de Lirismo" ${ }^{18}$, ele afirma que "a forma lírica se apresenta como uma poesia de 'circunstância"”19, valendose de uma definição de Goethe sobre circunstância como o momento imprevisto, como observa Fernando Guimarães. O "lírico" seria, assim, algo advindo do não esperado, não

\footnotetext{
${ }^{16}$ Apud GUIMARÃES, F. In: CASTRO, F.; REIS, C.; LOPES, O.; MARINHO, M., 2003, v. 07, p. 14.

17 Ibidem.

18 Publicado na Seara Nova, n. 233, out 1930.

${ }^{19}$ Apud GUIMARÃES, F. In: CASTRO, F.; REIS, C.; LOPES, O.; MARINHO, M., 2003, v. 07, p. 14.
} 
calculado. Não haveria, então, "nada de premeditado, de preconcebido, de preexistente" (GUIMARÃES, 1969, p. 18). O poema surge, para Gaspar Simões, de uma circunstância, um momento inesperado, como se se libertasse: “o poeta, enquanto cria, está entregue às forças instintuais de sua personalidade libertas num momento imprevisto" (Ibid.). A poesia, portanto, estabelece-se de um puro acaso.

Segundo Simões, ocorre ao lirismo uma oscilação entre um "circunstancial emotivo" e um "circunstancial intelectual" 20 " "passando de uma fase inicial - o indefinível anímico - para o indefinível intelectual"21, compatível com uma "transposição" que, conforme explica Gaspar Simões, seria a própria obra de arte. Os fatores anímico e intelectual consubstanciam-se no objeto artístico. Nos ensaios em que expõe essas ideias, são percebidas influências do discurso de Sigmund Freud nas palavras de Gaspar Simões, que traz um aporte da psicanálise para construir sua ideia sobre a arte, na qual a "auscultação do inconsciente" era antecipada por um "conhecimento consciente", como explica Guimarães $(1969$, p. 21).

Assim, os organizadores da Presença entendem que a expressão da arte é promovida pela individualidade do artista, ou seja, esta leva à recriação do mundo. Segundo ele, toda expressão artística parte "do mesmo instinto e do mesmo dom: o instinto, o dom que todos os homens possuem (mas só os artistas conseguem exteriorizar poderosamente) de recriar o mundo através da sua própria individualidade, ${ }^{22}$ ideia que se torna essencial ao pensamento presencista. Ocorre, portanto, o desenvolvimento de " [...] uma estética de teor individualista [...], que entendia que a sensibilidade do artista se prolongava num registo de intelectualidade, contribuindo para a revelação de um temperamento superior [...]", como observa Carlos Reis e António Lourenço (2015, p. 302)

Essas palavras colocam o artista em um patamar distinto dos homens ordinários, numa espécie de lugar absoluto, constituindo-se, assim, como um sujeito absoluto, único capaz de produzir a arte, a "literatura viva" da qual fala José Régio. Tal caminho trilhado pelos pensadores presencistas constitui o que Guimarães chama de "grande desvio" da revista em relação aos modernistas: "a realidade poética não é fundamentalmente referida à sua literalidade ou literaridade, isto é, ao seu espaço textual considerado em si mesmo". Tanto para Régio como para Gaspar Simões, os processos de criação artística remontam

\footnotetext{
${ }^{20}$ Expressões utilizadas por Fernando Guimarães.

${ }^{21}$ GUIMARÃES, F. In: CASTRO, F.; REIS, C.; LOPES, O.; MARINHO, M., 2003, v. 07, p. 15.

22 Ideias extraídas do artigo "Literatura Livresca e Literatura Viva". Presença, n. 09 apud GUIMARÃES, F. In CASTRO, F.; REIS, C.; LOPES, O.; MARINHO, M., 2003, v. 07, p. 15.
} 
e se direcionam sempre para a esfera do "eu", do sujeito, da sua individualidade e da sua personalidade.

A Presença, sendo uma publicação relativamente longeva, reuniu em torno de si nomes importantes como colaboradores e exerceu um papel muito relevante no quadro literário português. Fernando Pessoa, por exemplo, participou da revista, publicando os conhecidos poemas "Autopsicografia" e "Isto", além de textos fundamentais para a compreensão da sua obra, como a carta em que explica a gênese dos seus heterônimos. ${ }^{23}$ A revista ainda destacou os aspectos críticos e teóricos da literatura, como pondera Carlos Reis (REIS; LOURENÇO, 2015, p. 303). Porém, segundo Eduardo Lourenço (1987, p. 146), a atitude crítica desse periódico poderia ser descrita como um "psicologismo" talvez pela preponderância que os organizadores dão às experiências sensíveis como expressão poética.

A importância da revista e seu papel no cenário artístico português leva uma parte da crítica literária a ver no grupo presencista uma "herança quase linear" (REIS; LOURENÇO, 2015, p. 304), sendo um segundo modernismo, expressão atribuída a Adolfo Casais Monteiro, ainda que ele considere o termo "contestável”, de acordo com Reis e António Lourenço. Eduardo Lourenço, em seu ensaio "Presença ou a Contrarrevolução do Modernismo Português", discorda dessa visão, apoiando-se na ideia de que Orpheu resultou em uma "revolução poética" no campo literário em Portugal. Em termos metafóricos, o ensaísta nos diz que Orpheu, em uma revolução, está como "uma bomba explodindo", enquanto a Presença seria um discurso anarquista (LOURENÇO, 1987, p. 152), diferença que seria resultante de "duas implantações antagónicas da consciência poética em face de si e do universo" (Ibid., pp. 152-153). O crítico observa:

Assim, Sá-Carneiro e Pessoa não nos falam deles [conflitos reais com Deus, o Mundo ou os Outros], a título pessoal, mas só e sempre dessa ôntica distância que lhes devora a substância e os impede de se tocarem e tocarem o mundo. $\mathrm{O}$ verdadeiro real é a consciência da sua irrealidade essencial (Sá-Carneiro) e da essencial Irrealidade de Tudo (Pessoa). [...] $\mathrm{O}$ caso da poesia de Régio, de Torga e em certa medida o de Casais Monteiro é muito diverso. Os seus mundos poéticos [...] têm algo comum: a personalidade é neles um dado. O conflito imanente a essa poesia [...] é subjectivo, se com isso se quer assinalar o seu carácter de eminentemente pessoal. [...] O leitor do poema é imediatamente espectador, não o espetáculo como em Pessoa. Os actores suscitam uma atenção que na poesia de Pessoa se dirige logo ao objeto do poema (Ibid.).

\footnotetext{
${ }^{23}$ In: Presença, n. 49, 1937, apud REIS, C.; LOURENÇO, A., 2015, p. 303.
} 
Explanando tal raciocínio, Eduardo Lourenço nos indica que Presença se apresenta como "uma espécie de bonapartismo poético que, parecendo conduzir ainda a 'revolução' e dalgum modo a conduzindo, se serve dela para fins privados e mesmo opostos ao impulso revolucionário inicial” (Ibid., p. 162). Nesse âmbito, não seria adequado dar a nomenclatura de segundo Modernismo ao movimento presencista, pois não seria uma continuidade natural do movimento orfaico, e sim uma "refracção do Modernismo" (Ibid.).

Carlos Reis e António Lourenço observam, buscando resumir o movimento presencista, que surgem muitas diferenças entre os poetas desse grupo, mas isso seria coerente se pensarmos que um dos eixos que estrutura essa poesia é o "individualismo, princípio de negação de qualquer propósito de submissão a normas de inspiração coletiva" (2015, p. 306-307). Ambos ainda indicam que, atualmente, a crítica tende a afirmar que o movimento em torno da Presença "nos aparece como prática que regrediu em relação a ousadias (sobretudo formais) das vanguardas que a precederam [...]”, além da "valorização poética da sinceridade, prolongamento de um ethos romântico que em boa parte denegava o princípio e a prática do fingimento pessoano" (Ibid.), reforçando a importância da sensibilidade do artista e o apelo ao envolvimento emocional do leitor.

\subsection{Presença $\mathrm{X}$ Neorrealismo}

A perspectiva poética dos presencistas levou a revista a ser, frequentemente, alvo de polêmicas e discordâncias. Nesse quadro, em meados dos anos 30, a revista começa a receber críticas sobre o seu papel de abstenção diante do conturbado cenário político europeu e português do momento, uma vez que os seus pensadores defendiam uma especificidade da obra artística que não permitia aos valores estéticos reduzirem-se a valores sociais, como observa Guimarães (1969, p. 107).

Os portugueses presenciavam em seu território a ascensão do Estado Novo, regime ditatorial centralizado na figura de António de Oliveira Salazar (1889-1970) a partir de 1933. Três anos depois, a Guerra Civil Espanhola se inicia, levando à vitória de Francisco Franco e ao período ditatorial que se seguiu em 1939. No mesmo ano, dá-se início à Segunda Guerra Mundial e, mesmo que Portugal não tenha participado ativamente desse conflito, a sociedade assistiu aos terrores do período. 
Tais eventos, como observa Carlos Reis, foram "intensamente vividos em Portugal por homens de cultura que se opunham tenazmente ao salazarismo e que na Europa observavam [...] manifestações de uma muito aguda crise social e também de liberdades políticas" (In: MACHADO, A. 1996, p. 530.) A ascensão do Nazismo e do Fascismo e a consolidação de governos autoritários e ditatoriais - internamente, o fortalecimento do salazarismo - criaram um contexto de questionamentos sobre o papel do artista e da obra de arte em relação à realidade em que se inserem.

Em 1934, ocorre na cidade de Moscou, o congresso do Partido Comunista, e a sua repercussão em Portugal levou à "polarização dos marxistas-leninistas portugueses em torno de algumas revistas literárias que surgiram logo nesse ano e seguintes" (In: LOPES; MARINHO, 2002, p. 183), como observa Alexandre Pinheiro Torres. Aparecem nesse período, entre diversas revistas, O Diabo, em Lisboa, no ano de 1934, e Sol Nascente, de 1937, no Porto, publicações que indicavam um pensamento mais ligado às teorias de esquerda, criticando a literatura lusitana do momento. Diante disso, surgem críticas em torno da Presença e de sua concepção ideológica por parte de escritores que veem na obra de arte uma relação com as questões sociopolíticas de seu tempo, os quais viam um “abstencionismo" na revista, de acordo com Guimarães (1969, p. 107).

Em março de 1935, José Rodrigues Miguéis, em um depoimento ao jornal Diário de Lisboa, observa que as demandas daquele momento não faziam parte da literatura portuguesa. "Todas as inquietações do nosso tempo, tão rico de motivos, tudo que é essencial, está fora (ou quase) da nossa literatura. Onde está o romance de nossas lutas políticas? Que deu de si a guerra? E os problemas morais e sociais - a subversão de valores?" (1935, p. 06). O autor ainda ressalta que uma arte a qual não corresponde às questões do seu tempo está destinada ao esquecimento.

Críticas como a de Rodrigues Miguéis também aparecem em outros jornais e revistas de oposição ao salazarismo, como Seara Nova, Sol Nascente, O Diabo e Vértice. No exemplar número 44 de Presença, José Régio responde a essas observações dizendo que os problemas humanos apreendidos pelo artista podem ultrapassar o condicionamento sociológico e alargar-se a problemas psicológicos, estéticos, éticos, metafísicos e religiosos (GUIMARÃES, 1969, p. 107). Ocorre, porém, que não era a essa concepção que os críticos à Presença se referiam, pois, para estes, a relação a ser feita com a obra de arte é ligada a aspectos humanistas e sociais. Dessa maneira, cria-se uma espécie de conflito entre a posição de presencistas de um lado e a de seus críticos de outro. 
Entre os autores que se opõem à posição ideológica da Presença surge um movimento de orientação marxista enunciando uma nova postura relativa à criação artística, o Neorrealismo. Tal grupo, como observa Carlos Reis, ainda que de forma difusa, integra escritores como Alves Redol, Joaquim Namorado, Mário Dionísio, Fernando Namora, Carlos de Oliveira, Mário Braga, Afonso Ribeiro, Soreio Pereira Gomes, Manuel da Fonseca, António Ramos de Almeida, Manuel Campos Lima, Rodrigo Soares, entre outros (In: MACHADO, 1996, p. 530).

O Neorrealismo português desponta no contexto literário vinculado também ao posicionamento do artista diante do complexo quadro sociopolítico enfrentado por Portugal e pela Europa na década de 1930. Eduardo Lourenço observa que o movimento “como significativa realidade literária nasceu após a sua teorização, como vestimenta de uma Ideologia cuja força histórica, sugestão e potencial universalidade, a exigiam” (2007, pp. 11-12). Assim, esse grupo reivindica, no campo ideológico, uma tomada de consciência crítica diante do contexto em que a literatura se insere.

Perfila-se, desse modo, uma tensão entre a Presença e o Neorrealismo, cuja origem, segundo Rosa Maria Martelo, “deve ser procurada no debate essencialmente ideológico que, nos últimos anos da década de 30, se foi radicalizando e ocupou numerosas páginas da Presença e de jornais como O Diabo, Seara Nova e Sol Nascente, entre outros" (1996, p. 94). É um embate entre dois posicionamentos distintos, como observa Alexandre Pinheiro Torres

Confronto, pois, entre duas concepções de mundo totalmente diversas. A da Presença não pensava em quaisquer soluções para o mundo, porque os seus representantes intelectuais interessavam-se exclusivamente numa atividade, a do 'escritor' que 'escreve', a qual pressupunham com tenacidade como ser desligado dos interesses mais gerais (e logo inferiores) do comum destino humano. Não aceitavam que a obra dele pudesse ser, antes de mais e acima de tudo, fruto de uma consciência social, consciência na qual participava a própria 'singularidade' (ou 'excepcionalidade') psicológica do artista, como reflexo do mundo extremamente vasto e complexo onde se formou [...] (In: LOPES; MARINHO, 2002, p. 205)

Nesse sentido, a posição teórica do novo grupo que se reunia em torno de uma concepção marxista trazia uma significação nova do papel do autor e da obra artística, inserindo-a em um cenário de consciência social e papel ativo da escrita na transformação da realidade. 
Um aspecto que nos chama atenção no termo neorrealismo é justamente a relação que há - ou não há - com o movimento realista do século XIX e a geração de 1870 . Na realidade, o grupo neorrealista, que se molda aos poucos em âmbito teórico, busca operar um corte "em relação ao socialismo burguês do século XIX [...] e ao seu humanismo de índole claramente humanitarista", como explica Pinheiro Torres (In: LOPES; MARINHO, 2002, p. 205). As diferenças que marcam ambos os movimentos são ideologicamente significativas, e os novos autores se distanciam também dos anos oitocentos no que tange a técnicas literárias, sobretudo aquelas relativas a dois problemas fundamentais que os pensadores neorrealistas apontavam: "o posicionamento paternalista do escritor que observa a realidade, de certo modo numa perspectiva de intelectual não participante, e os excessos subjectivos ${ }^{24}$ da representação realista que [...] acabavam por aflorar à superfície do discurso" (REIS, 1981, p. 14).

Em termos gerais, tanto Alexandre Pinheiro Torres como Carlos Reis explicam que o Neorrealismo desvencilha-se da perspectiva materialista positivista que embasa o Realismo e, sobretudo, o Naturalismo, pautados em uma orientação teórica do socialismo e humanismo aos moldes de Proudhon, o qual pressupõe que cada homem deve despertar em si "a consciência de assumir, como atentados aos seus próprios direitos de ser humano e de cidadão, os atentados afinal desferidos contra os direitos idênticos de outros seres humanos e cidadãos mais desprotegidos da fortuna" (TORRES, in: LOPES; MARINHO, 2002, p. 185). A isso ele chama de "justiça" e a partir dela chega-se à razão e à verdade. Por conseguinte, alcança-se uma igualdade utópica. Isso, porém, não ocorreria por meio de revoluções, e sim em um ritmo biológico natural que conduziria à igualdade "como da larva nasce a borboleta", como verifica Torres (Ibid., p. 186).

Nesse sentido, para que a sociedade se modifique, basta que o homem reflita e busque sua mudança moral a partir de um princípio ético imanente. É essa noção de consciência moral que orienta o posicionamento crítico da geração de 1870 e ela se mantém na literatura portuguesa também com o grupo da Presença, segundo Torres (Ibid., p. 186) ao ler a obra de José Régio. Os neorrealistas organizam-se ideologicamente de forma a promover uma ruptura com esse pensamento oitocentista, assumindo uma visão baseada no materialismo histórico.

\footnotetext{
${ }^{24}$ É importante notar que a eliminação da subjetividade foi mais um elemento teórico do que prático na produção neorrealista, mas a experiência subjetiva desse grupo também se diferencia daquela dos realistas do século XX.
} 
Esse grupo, então, entende a literatura como "uma forma de consciência social" (REIS, 1981, p. 16), valorizando "a dimensão ideológica da criação literária, bem como a sua capacidade de intervenção sociopolítica" (Ibid.). Essa postura diante da arte rompe com a visão que vinha sendo elaborada pelos presencistas, uma vez que agora a literatura assumiria uma "missão desmistificadora de contradições de natureza socioeconómica, sobretudo concretizada pela sua possibilidade de, articulando-se com a história, reflectir essas realidades normalmente deprimentes" (Ibid.). Tais "realidades" foram trabalhadas pelos neorrealistas a partir de escolhas temáticas muito singulares - nas quais, aliás, percebe-se diferenças agudas com o que o movimento realista do século XIX trouxe como aporte de temas. Assim, como destaca Eduardo Lourenço, a obra neorrealista vai se configurar como "encarnação efectiva de uma precisa visão da história e do mundo" (2007, p. 13).

Um aspecto essencial da crise entre Presença e os neorrealistas reside na crítica de que o quadro ideológico de base marxista representaria aos "novos" escritores uma imobilidade no campo da criação artística, como se estes fossem mais "presos" que aqueles, uma vez que "obedeceriam" a um conjunto de regras temático-ideológicas. Eduardo Lourenço rebate essa ideia, mostrando que, ainda que houvesse uma "obediência ideológica", o espaço de criação dentro de tal concepção era, sim, aos neorrealistas, um espaço de liberdade, pois a fidelidade ideológica não pode ser confundida como "mutilação" ou "sacrifício" (2007, pp. 13-14).

Para os presencistas, tal enquadramento representava submissão e cerceamento da liberdade e da individualidade do artista, o qual deveria manter-se acima ou à margem dos eventos históricos e políticos, como explica Pinheiro Torres. O autor explica que essa visão encontra relação com as ideias do livro La Trahison des $\operatorname{Clercs}^{25}$ (1927), de Julien Benda, no qual se explorava a imagem do "clerc", o artista que se mantinha distante dos aspectos sociopolíticos do seu contexto, e sua traição seria servir a um intuito de arte que não fosse "a arte pela arte" 26 , isto é, aquele que, em vez de buscar os valores do belo da obra artística, submetesse-a a um engajamento ideológico. É esse o ambiente do conflito entre presencistas e neorrealistas, no qual a expressão individualista ou individualizada do escritor estará em oposição à concepção coletiva do homem.

\footnotetext{
${ }^{25}$ Convém notar que o livro La Trahison des Clercs foi publicado em um período em que artistas e intelectuais buscavam trazer em suas obras aspectos políticos e ideológicos de uma forma geral. Assim, a crítica compreende que a visão de Benda se direciona não somente a autores de cunho marxista mas também a intelectuais ligados ao fascismo ou ao nacionalismo europeu da década de 1930.

${ }^{26}$ Cf. TORRES, A. In: LOPES, O.; MARINHO, M., 2002, p. 191.
} 
Alves Redol, em uma conferência que apresenta na Associação de Construção Civil, em Vila Franca de Xira, de nome "Arte", faz uma crítica direta à noção de "arte pela arte" 27 , afirmando que esse conceito seria extravagante para aquele período, pois "todos os assuntos devem servir em proveito do homem, se não querem uma vã e ociosa ocupação. [...] a arte deve servir também para algum proveito essencial e não dever ser apenas um prazer estéril". ${ }^{28}$ Ademais, a arte deveria "contribuir para o desenvolvimento da consciência e para melhorar a ordem social". Não seria mais possível, conforme o pensamento neorrealista, que o escritor se colocasse à margem dos problemas que atingiam a sociedade europeia e portuguesa nos anos 1930, e a arte deveria refletir essa militância, promover o pensamento e ser parte essencial da mudança.

O Neorrealismo começa a ser teorizado e veiculado inicialmente nas revistas Sol Nascente e $O$ Diabo, em que se mostrava evidente "o espírito de sintonia com a própria vida política das frentes populares e com todas aquelas manifestações culturais que a reflectiam" (In: LOPES; MARINHO, 2002, p. 193), conforme observa Torres. Em termos cronológicos, costuma-se fazer referência ao início do movimento neorrealista a partir da publicação do romance Gaibéus, de Alves Redol, publicado pela primeira vez em 1939. Em poesia, esse papel é atribuído à publicação do Novo Cancioneiro, que começa a ser publicado em 1941 e constitui, "ainda que com o convencionalismo inerente a esse tipo de datação, a primeira manifestação clara de uma ruptura, o passo inaugural de um itinerário poético específico cuja definição se viria a fazer no sentido de aprofundamento do que então se iniciava" (MARTELO, 1996, p. 92).

Os fundamentos ideológicos do Neorrealismo formatam, como observa Carlos Reis, o aporte temático que perpassa tanto a ficção como a poesia desse movimento. Esses temas consolidam no plano prático a ideologia que dá base ao grupo, uma vez que "a temática constitui um dos domínios fundamentais de toda a obra literária de feição comprometida e interventora, já que é no seu domínio que se insinuam as grandes coordenadas semânticas determinadas pela ideologia que lhes está subjacente" (REIS, 1981, p. 17). É nesse âmbito que se pode perceber uma clara distinção entre o Realismo oitocentista e o novo movimento, pois, enquanto aquele trouxe temas de preocupação da

\footnotetext{
27 É importante esclarecer que esse termo, utilizado em larga escala pelos neorrealistas, pode ser compreendido como uma arte voltada para os aspectos de beleza, sem haver um pensamento crítico voltado à reflexão de questões sociais. Assim, para os neorrealistas, a "arte pela arte" presencista definese pelo fato de esta ser fortemente ligada a expressões individualistas, que buscariam a sensibilidade do "eu" em detrimento de uma postura mais politizada ou, pelo menos, preocupada com aspectos coletivos. ${ }^{28}$ Discurso de Alves Redol citado em TORRES, A. In: LOPES, O.; MARINHO, M., 2002, p. 191.
} 
vida burguesa - o adultério, a ambição, a usura, educação -, os neorrealistas trazem questões, em geral, ligadas ao campesinato e ao proletariado, aprofundando imagens relativas à condição econômica desses grupos e buscando explorar pontos como os conflitos sociais, a manipulação ideológica e a alienação, a consciência de classe, exploração pelos donos dos meios de produção, opressão, posse de terra e decadência dos estratos dominantes, segundo Reis (1981, p. 17).

Assim, a concepção de literatura e o próprio "conteúdo" literário, por assim dizer, que o novo grupo traz é claramente distinto ao que os anos oitocentos trouxeram com o movimento realista. $\mathrm{O}$ grupo apresentava uma defesa prática do socialismo marxista e se punha contrário ao "socialismo idealista, utópico, antirrevolucionário e burguês de oitocentos" (TORRES, 1983, p. 34). Jofre Amaral Nogueira, em seu artigo "O Papel duma Nova Geração" ${ }^{29}$, apresenta a defesa de uma literatura que combata a visão da geração de 1870 e um posicionamento que se distancia da noção da "arte pela arte", pois sua principal crítica é o culto central ao indivíduo na sociedade.

Os autores que se colocavam em posição contrária aos presencistas são fortemente influenciados por dois acontecimentos na Europa na década de 1930, que os incentiva a unir forças contra o autoritarismo do governo ditatorial português e a lutar contra o Fascismo. Na França, ocorre em 1934 a união entre socialistas e comunistas, formando a Frente Popular, movimento que fora influenciado pela adesão de muitos intelectuais à esquerda, expondo um papel relevante da arte na reflexão crítica das manifestações de massa. Na ocasião do 14 de julho do ano de 1935, a Frente Popular francesa organizou movimentos por todo o país, para expor a força dos grupos de massa na luta pela democracia e no combate aos fascistas. Esse processo teve fortes influências na Espanha, onde também se formou uma Frente Popular. Em ambos os países, os partidos de esquerda conseguem ótimos resultados nas eleições de 1936, o que agita os ânimos dos escritores portugueses ligados ao pensamento marxista.

Apesar do êxito das Frentes Populares, deflagra-se na Espanha a Guerra Civil em 17 de julho. Os horrores desse período, somados ao desejo de intelectuais portugueses que também queriam se opor ao Fascismo, levou a uma situação em que "não podia haver realmente grandes complacências para com aqueles escritores (por muito modernistas que fossem) que se encontrassem ou se confessassem mais ou menos desligados dos destinos do mundo" (TORRES, 1983, p. 39). Pinheiro Torres destaca a intensa influência que o

\footnotetext{
29 NOGUEIRA, Jofre Amaral. “O Papel duma Nova Geração”. In: Sol Nascente, n. 28, 15 abr 1938 (apud TORRES, A., 1983, p. 36).
} 
sucesso - ainda que breve - das Frentes Populares espanhola e francesa exerceu no novo grupo, o que pode ser verificado nas publicações que teorizavam o Neorrealismo nas revistas Sol Nascente e O Diabo, nas quais “é evidente o espírito de sintonia com a própria vida política das Frentes Populares e com todas aquelas manifestações culturais que a reflectiam" (Ibid.).

Esses intelectuais também são influenciados por livros que trazem o ideário marxista-leninista, o que foi fundamental para a formação de uma estética literária que anuncie esse pensamento e dará origem ao Neorrealismo. Entre as obras que foram lidas e que suscitaram a reflexão crítica desses autores, Alexandre Pinheiro Torres destaca duas principais: La Crise du Progrès, de Georges Friedmann, e La Conscience Mystifiée, de Henri Lefebvre e Norbert Gutermann, ambos de 1936. Tais publicações apresentam propostas que mostram o papel preponderante do materialismo dialético para a libertação do proletariado explorado e iludido pelo capitalismo e pelo Estado burguês (Ibid., p. 41).

Entre os temas abordados pelas obras, destacam-se a noção de alienação e ilusão de dignidade social que o Estado e a sociedade capitalista promovem para o grupo dos proletários e camponeses; exploração dos donos de meio de produção e formação de uma alta burguesia; contradições da sociedade capitalista, que empobrece um setor para o êxito econômico de outro e a marginalização do proletariado e do campesinato, conforme explica Torres (1983, pp. 38-39). Esses assuntos formam, nas produções neorrealistas, o conjunto de temáticas exploradas, tanto na poesia como na ficção de um modo geral.

Além disso, traduções de Karl Marx, Friedrich Engels e Lênin circulam entre os intelectuais de esquerda, trazendo uma forte influência para o âmbito artístico. O livro, porém, que será o "ponto de partida" de uma estética literária marxista é, segundo Pinheiro Torres, A Arte e a Vida Social, de George Plekhanov ${ }^{30}$, publicado em 1911.

\footnotetext{
${ }^{30}$ George Plekhanov, nome ocidentalizado de Gheorgi Valentinovitch Plekhanov, é um pensador e escritor nascido na província de Tambov, no território russo, em novembro de 1856. Já na sua juventude, ele passa a militar politicamente em favor da classe dos trabalhadores urbanos, e baseava-se no pensamento marxista para defender seus ideais. Em 1882, publica sua tradução para o russo do Manifesto Comunista, trazendo um prefácio de Karl Marx. Cria, em Genebra, o Grupo Emancipação do Trabalho, o principal núcleo do marxismo na Rússia no fim do século XIX, que faziam traduções de textos de Engels e Marx, oferecendo aos revolucionários russos expressiva influência. Os historiadores observam que o pensamento de Plekhanov influenciou de forma significativa as bases ortodoxas do marxismo russo, inclusive de Lênin no início da sua atividade política. Seus livros, ensaios e traduções lhe renderam a fama de "pai do marxismo russo" e permitiram, além da disseminação deste, uma forte crítica ao populismo do país. Ele delineou a estratégia a longo prazo do movimento revolucionário russo até 1914 . Seu livro $A$ Concepção Materialista Histórica, publicado em russo, em 1895, promove um panorama sobre a evolução do pensamento filosófico e social, passando por Hegel e Feuerbach, sendo o primeiro a se referir às teorias marxianas como "materialismo dialético". A partir de 1905, sua atuação política passou a diminuir acentuadamente, dedicando-se aos estudos filosóficos e históricos. Volta para a Rússia em 1917, após permanecer 35 anos exilado, mas considerou que a tomada de poder pelos bolcheviques fora algo
} 
Considerado um dos principais fundadores do pensamento marxista na Rússia, o autor apresenta nesse livro uma denúncia a um tipo de artista que, aparentemente, mostra-se revolucionário, mas, se bem analisada sua obra e sua postura, expressa-se de modo a manter as estruturas sociais já existentes. A base de sua crítica é o prefácio de Théophile Gautier a Mademoiselle de Maupin, texto que serviu a intelectuais burgueses os quais buscavam "escandalizar sua classe" sem, no entanto, promover reflexões que indicassem mudanças.

Essa obra trará argumentos ao grupo neorrealista, sobretudo em sua celeuma com os presencistas. De acordo com Plekhanov, tudo que possa contribuir para que se tenha maior justiça social é útil ao indivíduo, sobretudo aquilo que desvele os "desmandos do homem". Conforme verifica Pinheiro Torres,

\begin{abstract}
O artista deverá centrar sua obra em torno dessa ideia básica, não deverá limitar-se ao autocomprazimento de seu ego, a partir do qual acaba por ver o mundo desfigurado, perdidas todas as ligações profundamente sérias com o mundo concreto. Ora, assenta Plekhanov, tudo o que contribua para que se atinja um estado maior de justiça social, tudo o que traga um contributo positivo para que a opressão acabe, tudo é progresso social, e uma arte ligada a esta ideia estrutural é certamente uma arte socialmente progressiva. Progressiva no sentido de se considerar como superior a posição em que se coloque o artista no centro dos acontecimentos do mundo, não acima ou ao lado deles (1983, pp. 43-44).
\end{abstract}

Assim, ainda segundo Plekhanov, uma obra de arte que traga a visão de um artista que considere as suas experiências ligadas ao ego como superior não promove nada de importante a uma sociedade que viva na opressão, inserida em desigualdade social e vítima de injustiças. Nesse sentido, o autor russo fala da arte útil e da arte inútil, ideia que fomentará a defesa dos neorrealistas em relação a arte desinteressada pelos problemas do mundo da Presença.

Para os pensadores dessa revista, porém, a polêmica entre "arte pela arte" e "arte social" é explicada pela visão de que uma arte a qual abordasse questões de caráter social era concernente ao campo da Sociologia, e não ao da Literatura, como explica Torres. O novo grupo que vinha se assentar em bases marxistas, mas se reconheciam como artistas também, julgavam esse pensamento um equívoco. Em seu artigo "Um Livro, Um Crítico e Uma Questão”, António Ramos de Almeida afirma que esse conflito entre presencistas

prematuro, o que poderia ter graves consequências ao movimento e ao país. Ele morre em maio de 1918, em Terijoki, na Finlândia. (cf. verbete "Plekhanov" no Dicionário do Pensamento Marxista). 
e neorrealistas é algo de artista para artista, e ainda observa que "a polémica arte pela arte/arte social, em termos absolutos, teóricos e gerais, não tem sentido, reduz-se a uma simples questão de palavras" ${ }^{31}$. Ramos de Almeida afirma que o novo grupo não deixa de ser de artistas por se preocuparem com temáticas sociais, dizendo que é necessário compreender um novo ponto de vista e "novos horizontes estéticos" que não estejam inseridos numa perspectiva "hipersubjectivista, hermética, esotérica, egocentrista etc", de acordo com Torres. (In: LOPES; MARINHO, 2002, p. 199).

Sobre o conflito, Fernando Guimarães observa que

No fundo, o que se jogava era a questão de saber até que ponto se podia ou não conciliar os interesses colectivos ou da sociedade com os chamados interesses da literatura; e, para prosseguir nesse jogo, recorria-se a uma por vezes ambígua dicotomia que poderíamos enumerar em função dos conflitos ou oposições existentes entre arte pela arte e arte de propaganda, crítica formalista e crítica neohumanista, forma e conteúdo, assunto e maneira, abstracto e concreto, imaginação e realidade, originalidade e utilidade, arte e vida, eu individual e eu social etc (1969, p. 112).

As dicotomias, assim, tentariam definir os propósitos da arte e, naturalmente, do artista, mas acabariam por levar a atitudes extremas ou ambíguas na defesa de um ponto de vista que seria o "certo" ou, melhor dizendo, o "mais adequado" à arte.

A percepção sobre a arte e o artista, de fato, determina um embate ideológico entre a Presença e o Neorrealismo português, como observamos. Tal tensão, entretanto, não omite que há entre os dois movimentos algumas zonas de contato, como observam os críticos literários. Guimarães (Ibid., p. 113), por exemplo, verifica uma aproximação entre ambos os grupos a partir da influência promovida pela poesia de Afonso Duarte. Esse autor, nascido em 1884, acompanha todos os movimentos do Modernismo em Portugal e colaborou, entre várias revistas, com a Presença, mas também com a Seara Nova.

Duarte configura-se como um escritor que se interessa por etnografia e arte popular, o que traz à sua obra, muitas vezes, temas ligados à vida rural dos portugueses, algo bem evidente no livro Ossadas, em $1947^{32}$. Assim, Guimarães ressalta que, mesmo dentro desse eixo temático, o autor foi um colaborador presencista, o que não impede que ele se torne uma importante influência aos neorrealistas. Carlos de Oliveira, inclusive, fala do autor em seu ensaio "O Iceberg", no qual reconhece nele um caso de "grandeza

\footnotetext{
${ }^{31}$ ALMEIDA, António Ramos. “Um Livro, Um Crítico e Uma Questão” (apud TORRES, A., 1983, p. 48).

${ }^{32}$ Apesar de ser publicado em 1947, o livro Ossadas reúne poemas que já circulavam entre os leitores desde a década anterior.
} 
real" (2004b, p. 169). Duarte, assim, mostra que o conflito entre os neorrealistas e os presencistas pode ocultar alguns pontos de contato.

Além disso, em sua análise, Guimarães sugere: "muitas das preocupações humanistas a que estes [neorrealistas] aderiram não eram comuns a um inconformismo revoltado, à defesa de uma literatura mais 'interessada', que se deparavam em Miguel Torga [...]?" (1969, p. 113). Novamente, o crítico indica um ponto de contato entre os grupos, uma vez que Torga é um reconhecido participante da Presença, não somente como colaborador mas também como diretor da revista. É necessário, porém, contemplar o fato de que o autor rompe com o grupo de 1927, em princípio por motivos de discordância. Ainda assim, Guimarães busca destacar que a literatura mais "preocupada" com questões sociais já é algo notável em Torga.

Deve-se verificar também que, entre os neorrealistas, Namora, Cochofel e Mário Dionísio chegaram a publicar poemas na Presença. Curiosamente, conforme explica este último, "os raros poemas publicados pelos ditos poetas na dita revista, ou eram já os mesmos que veriam mais tarde a publicação em livro do Novo Cancioneiro, ou eram poemas inteiramente presencistas ou pelo menos de ambiente presencista" (apud GUIMARÃES, 1969, p. 113), o que nos mostra mais um indício de zona de contato entre ambos os grupos. No entanto, um contato mais acentuado pode ser observado no campo formal da poesia neorrealista. O advento da publicação do Novo Cancioneiro vem consagrar que "de resto, mesmo no plano de criação literária, há sem dúvida um terreno comum aos presencistas e àqueles poetas que se prenderão às preocupações da nova corrente" (Ibid. p. 112), segundo Guimarães, o que também é analisado por Eduardo Lourenço e Rosa Maria Martelo.

O Novo Cancioneiro, que se constitui como uma coletânea de dez volumes de poesia publicados entre 1941 e 1944, deveria “concretizar, no plano da prática poética, uma mudança que a crítica de índole marxista vinha anunciando e constituir a resposta, pela positiva, a quanto de negativo era apontado ao presencismo, que essa mesma crítica via (ou queria ver) agonizar” (MARTELO, 1996, p. 92). A questão ideológica aparece na poesia "menos como inspiração do que quadro" (LOURENÇO, 2007, p. 16), sendo o "elemento determinante da dificuldade de o canto neorrealista se encarnar com a plenitude ideal buscada pelos seus poetas", conforme observa Eduardo Lourenço (Ibid.). No âmbito da criação poética, porém, o conflito entre ambas as vertentes não se mostra tão acalorado, uma vez que alguns dos autores desse novo grupo reconhecem-se dentro de uma estética fortemente influciada pela Presença. 
Martelo (1996, pp. 92-93 ) observa que, curiosamente, na ocasião do término da revista Presença, em 1940, três poetas que integram o Novo Cancioneiro - a saber, Fernando Namora, Carlos de Oliveira e João José Cochofel - assinam a "Carta Aberta a Adolfo Casais Monteiro, João Gaspar Simões e José Régio", em que se lamentam o fim da publicação, identificada como "a revista à qual devemos a nossa formação de $\operatorname{artistas"~} 33$. Oliveira ainda faz um comentário sobre suas primeiras expressões artísticas ainda enquanto estudante: "Por lá ouvi ainda os últimos rumores da renovação presencista, que nós, apesar de tudo, compreendemos e admirámos melhor do que é hábito dizer-se[...]"34.

Diante do acalourado debate ideológico, esperava-se que o Novo Cancioneiro trouxesse poeticamente "uma alternativa ao magistério presencista, sobretudo na sua vertente regiana", como indica Martelo (1996, p. 92). Porém, a autora observa que "na poesia dos jovens reunidos em torno do Novo Cancioneiro não é possível ler-se, pelo menos com a amplitude que lhe é atribuída, essa ruptura que exteriormente se anuncia" (Ibid., pp. 93-94). Para Alexandre Pinheiro Torres, "uma coisa era o Neorrealismo ideal que se predicava, outra o real que se viria praticar [...]" (1983, p. 46), o que seria resultado de uma recusa dos presencistas em "verem na nova geração outra coisa que não fosse a vontade de fazerem vingar um novo conteúdo e nada mais [...] (Ibid.).

Martelo (1996, p. 92) observa que, para o escritor José Gomes Pereira, descrito por ela como "companheiro da geração de 40", apesar de ser mais velho que os demais, não se passa despercebido o fato de a publicação "por excelência" neorrealista não se distanciar tão bruscamente com o que se vinha fazendo em âmbito formal na Presença, reconhecendo que a ruptura se dá, na prática, nas questões ideológicas e filosóficas. Segundo ele, a explicação do escândalo seria

[...] a tentativa de substituição das bases filosóficas tradicionais da poesia portuguesa (dualista, platónica, cristã etc.) pelo materialismo dialéctico de que alguns artistas jovens de extracção pequeno-burguesa se julgavam imbuídos. O mais - lirismo, ódio, amor, cólera, ironia, populismo, boas intenções, desesperança, esperança etc. - dependia da índole de cada um (apud MARTELO, 1996, p. 92).

\footnotetext{
${ }^{33}$ Trecho extraído da carta que está publicada em: SIMÕES, João Gaspar: José Régio e a história do movimento da Presença. Porto: Brasília Editora, 1977, pp. 367-368 (apud MARTELO, R., 1996, p. 93).

${ }^{34}$ NASCIMENTO, Manuel: “Encontro com Carlos de Oliveira”. In: O Primeiro de Janeiro, 21 abr 1954 (apud MARTELO, R., 1996, p. 94).
} 
Sendo assim, o autor insere a mudança nos poetas, muito mais do que na poesia, como afirma a crítica. Assim, não necessariamente o plano da forma se mostra como fator de ruptura entre o grupo de 1927 e o novo movimento que se estabelecia a partir do Novo Cancioneiro.

Entre presencistas e neorrealistas, podemos observar semelhanças fundamentais nos processos de escrita, segundo Guimarães, mostrando que, mesmo com a ruptura ideológica, a forma da nova poesia mantém algumas proximidades que talvez não fossem ressaltadas no então momento. Entre tais aspectos, o autor cita

Certos meios espectaculares de comunicação ou de desenvolvimento emocional que criam uma escrita dramatizada, um afastamento de certos tropos geralmente denunciados pela inautenticidade retórica ou formalista que lhe é atribuída, como os símbolos e as metáforas, os quais cedem terreno à alegorização; a incapacidade de superar, no plano da linguagem, os estados de consciência individuais quer pela ironia, quer acedendo a uma expressão épica, por ventura simulada pela utilização de recursos estilísticos habitualmente exteriores, como as anáforas e as enumerações caóticas, ou por um desarvoramento ${ }^{35}$ discursivo e quase didáctico capaz de apenas antecipar [...] uma consecução novelística (1969, p. 114).

Assim, o autor considera que, no campo do conteúdo, os presencistas dão uma visão psicológica e individualista a muitos conflitos e imagens sociais, e o movimento neorrealista traz um plano mais completo, o "eu social”. Apesar disso, a construção poética do novo grupo, por vezes, “encosta” nessa perspectiva já existente.

O conflito, desse modo, reside, segundo os críticos, muito mais no plano da ideologia do que no campo formal da poesia neorrealista. Martelo segue sua análise com a explanação da ideia de que essa polêmica se deve à construção equivocada da imagem que presencistas tinham da poesia fundamentada no materialismo histórico e, ao mesmo tempo, da imagem igualmente incerta que os autores de base marxista tinham da revista do grupo de 1927. Conforme nos explica a autora

Os detractores da Presença tendem a reduzir a sua poética, sobretudo através da imagem projectada de Régio, à "arte pura", isto é, a uma forma de arte na qual sublinham o estatismo, o isolamento do artista na torre de marfim do perfeccionismo estético e um individualismo carregado de conotações mais negativas, recusando-lhe a possibilidade de coordenação com o humano em sentido transindividual; os

\footnotetext{
35 Em relação ao "desarvoramento discursivo e quase didáctico", Fernando Guimarães cita o caso de Fernando Namora e indica a leitura de uma análise feita por Luís Veiga Leitão sobre essa escrita, presente no livro Ciclo de Pedras (ed. Portugália) como prefácio.
} 
presencistas, por sua vez, tenderão a reduzir o papel da nova geração anunciada ao de meros executantes, no plano literário, de um projecto político-social, isto é, a acusá-los de secundarizar os valores estéticos em arte (1996, pp. 100-101).

Sendo assim, a tensão seria limitada a uma visão quase caricatural mútua e, por vezes, radical em extremo. Esta, contudo, não apaga marcas de contato no âmbito da forma das poesias.

Esse aspecto, no entanto, não será mais aprofundado no escopo deste trabalho. Apesar disso, convém ressaltar que, ainda que o Neorrealismo em sua expressão formal não tenha promovido mudanças profundas no processo artístico, o movimento traz, a partir de seu aporte ideológico, uma concepção coletiva e social do papel do artista e do sujeito poético, o que resulta na elaboração de um conjunto de temas e imagens que foi marcante na literatura portuguesa, sobretudo se considerarmos o anseio de muitos intelectuais por uma arte vista em consonância com os problemas de origem sociopolítica que afetavam não somente portugueses, mas a Europa como um todo.

\subsection{O pensamento neorrealista português e a literatura neo-humanista estrangeira do século XX}

De forma geral, o poeta e o ficcionista neorrealista buscam se inserir em uma visão socioeconômica e política de conceitos ligados à exploração financeira, física e moral do homem sobre o homem, a violência física e simbólica desse processo, a miséria e as imposições sociais que (de)formam o indivíduo, submetendo-o à força e ao poder do outro, além de outros temas que têm sua base no pensamento materialista histórico. $\mathrm{O}$ olhar para essas questões não está isolado evidentemente, e o novo grupo se direciona ao diálogo muito significativo com a literatura estrangeira afim. Destacam-se nessa relação, como indica Carlos Reis, o realismo socialista ligado a obra de Maksim Gorki, a chamada "geração perdida" "36 norte-americana, entre eles Steinbeck, Hemingway e Caldwell, "e sobretudo no romance brasileiro nordestino que, por razões culturais e até afectivas, representou, mais do que qualquer outro, o modelo preferido pelos escritores neorrealistas" (1981, p. 27). Para o crítico, essa ligação já é vista a partir dos textos críticos do Neorrealismo, que trazem análises sobre a literatura estrangeira que estava em consonância com o pensamento do novo grupo. ${ }^{37}$

\footnotetext{
${ }^{36}$ Expressão utilizada em REIS, C., 1981, p. 27.

${ }^{37}$ Carlos Reis cita de forma mais específica alguns desses artigos. Cf.:1981, pp. 27-28.
} 
Sobre tal relação entre o Neorrealismo português e a literatura neorrealista regional brasileira, Gonçalo Duarte ${ }^{38}$, em seu estudo sobre o trágico em Carlos de Oliveira e em Graciliano Ramos, observa que, entre os autores do Brasil mais apreciados, encontramos Jorge Amado, José Lins do Rego, Graciliano Ramos, Amando Fontes, Raquel de Queirós, José Américo de Almeida e Marques Rebelo. Essa apreciação dos lusitanos se daria sobretudo pelo "cariz social” (DUARTE, 2008, p. 25). A característica principal do romance regionalista da década de 1930 no Brasil - principalmente aquele ligado ao matiz "nordestino" - como se sabe, reside na elaboração de temáticas ligadas a classes sociais normalmente esquecidas e marginalizadas da população brasileira. Assim, essa literatura trouxe à luz a denúncia social e a crítica sobre processos de exploração do homem, opressão, subalternidade e exclusão socioeconômica que ocorriam em setores mais desfavorecidos do território.

O Neorrealismo brasileiro configura-se na produção ficcionista por trazer como partes do processo criador a observação, a descrição, o relato e a análise dos quadros sociais que são elaborados como imagem e narrativa do quadro socioeconômico e político nordestino da década de 1930. O embasamento ideológico desse conjunto de autores aproximava-se também daquilo que os neorrealistas portugueses discutiam como pilares do movimento, ou seja, assuntos e questões de base materialista histórica, com algumas influências também do discurso psicanalítico muito em voga no período a partir do desenvolvimento das teorias de Sigmund Freud.

O quadro político português também se aproximava ao brasileiro se considerarmos que, na década de 1930, institui-se uma maior centralização do poder ditatorial na figura de António de Oliveira Salazar, que, em 1928, assume o Ministério das Finanças e, em 1932, é nomeado presidente do Conselho de Ministros. Enquanto isso, em terras brasileiras, a população assistia à ascensão de Getúlio Vargas e a instauração de um governo ditatorial entre 1930 e 1945. Ainda nessa década, em ambos os países há o início do Estado Novo: em Portugal, isso decorre da promulgação de uma nova constituição em 1933 e tem a maior duração de um governo de exceção na Europa - 41 anos; no Brasil, o Estado Novo se inicia em 1937, com o fechamento do Congresso Nacional e a instituição também de uma nova constituição.

\footnotetext{
${ }^{38}$ Cf. DUARTE, G., 2008.
} 
Com o fim do período conhecido no Brasil como República Velha ${ }^{39}$, muitos problemas graves ligados às regiões Norte e Nordeste são desvelados, e é nesse quadro que se insere, a partir de meados dos anos 1920, o romance regionalista brasileiro, o qual se desenvolve acentuando sua perspectiva de denúncia e crítica social. Em âmbito mais amplo, o Brasil também foi muito prejudicado com a crise econômica de 1929, que levou a mudanças significativas nas estruturas socioeconômicas que controlavam o país financeira e politicamente, como a oligarquia mineira do Gado, a cafeeira em São Paulo e os Engenhos de Cana-de-açúcar no Nordeste. Esse é, aliás, o cenário das obras de José Lins do Rego do chamado "ciclo da cana-de-açúcar", no qual são inseridos os romances Menino de Engenho (1932), Doidinho (1933), Banguê (1934), O Moleque Ricardo (1935), Usina (1936) e o célebre Fogo Morto (1943).

A abordagem da literatura brasileira relativa ao chamado segundo Modernismo ecoa, assim, de forma muito significativa na criação artística dos portugueses neorrealistas, como comprova uma série de artigos em que se analisaram as obras dos brasileiros nas revistas $O$ Diabo e Sol Nascente ${ }^{40}$. A opção por retratar classes e regiões excluídas e desvalorizadas socioeconomicamente, a opção por um registro mais oral mais próximo do popular regional na linguagem e, obviamente, a perspectiva crítica de viés marxista vêm ao encontro da busca, pelo novo grupo português, de um artista e/ou de uma literatura que estivessem atentos aos problemas sociais do seu momento.

Nesse âmbito de influências e diálogo, é importante notar que os neorrealistas, apesar de exporem bases ideológicas segundo as quais discutiam o papel da obra de arte e de seu criador, não chegaram, ainda em meados da década de 30, a construir um projeto poético neorrealista. Por isso, segundo Rosa Maria Martelo, "não há uma desvalorização estética da Presença porque também não há, ainda, uma contraproposta efectiva coerente, global, estruturada - no campo da poética" (1996, p. 104), mesmo que os anos finais de 1930 tenham sido uma época extremamente fecunda para o desenvolvimento

\footnotetext{
39 Período entre 1889 e 1930 em que a elite cafeeira paulista e a mineira alternavam-se para assumir cargos políticos no país, sobretudo o cargo da Presidência.

40 Alexandre Pinheiro Torres cita em nota de rodapé (1983, pp. 103-104): “os artigos de Mário Dionísio sobre Jorge Amado (O Diabo, n.o 164 a 167, 14 de Novembro de 1937 - 5 de Dezembro de 1937), de Joaquim Namorado sobre Amando Fontes (id., n.o 223, Dezembro de 1938), de Afonso Ribeiro sobre José Lins do Rego (Sol Nascente, n. 17 de 15 de Outubro de 1937) e sobre o "Romance Brasileiro Contemporâneo» em geral (id., n.o 28 de 15 de Abril de 1938), o importante estudo de Alves Redol também sobre Amando Fontes (id., n. 29 de 15 de Maio de 1938), onde o autor de Gaibéus declara ser Cimento de Gladkov o melhor livro que leu, e os de António Ramos de Almeida sobre Jorge Amado, Amando Fontes e José Lins do Rego (id., n.o 31 e 32 de 15 de Agosto e 1 de Dezembro de 1938) [...]".
} 
teórico do novo movimento. Esse elemento teórico traz, como observa Eduardo Lourenço (2007, p. 12), algumas consequências aos escritores neorrealistas, os quais, no princípio da manifestação como grupo, foram convertidos numa espécie de "guardiões" ou "apóstolos" de uma ortodoxia literária, isto é, deveriam ser culturalmente aquilo que se propunha ideologicamente, "uma sombra do ideal" (Ibid.).

Como grupo, os neorrealistas pleiteiam uma nova concepção da dimensão do artista, buscando destacar o que havia "de homem (de social)" nele. Nessa busca e na polêmica cisão forma-conteúdo que enfrentavam, surge uma contradição no movimento, conforme elabora Lourenço, entre "uma boa consciência imaginária e a concreta dificuldade de exprimir o que idealmente pretendem encarnar" (Ibid. p. 15), sobretudo a poesia. Sendo assim, ainda que o aporte teórico ideológico esteja entranhado nessas criações líricas, os poetas neorrealistas são, "como foram sempre os autores, prisioneiros da dificuldade substancial de dar um corpo adequado à visão que os conduz" (Ibid.). O norte para o grupo foi o pensamento de que "os indivíduos são um produto do meio, mas que, por sua vez, esse meio é, em grande parte, produto em suas mãos"41. Entretanto, poeticamente, cada autor deu ao ideal neorrealista uma roupa à sua maneira, e os poemas dispersos que proclamavam essa nova reflexão serão condensados na publicação Novo Cancioneiro.

\subsubsection{Carlos de Oliveira - a voz da Gândara}

É nesse quadro que Carlos de Oliveira vai inserir seu trabalho poético. Em uma perspectiva mais ampla, esse autor se inscreve de forma mais completa ao ideal neorrealista, pois, além da lírica, sua criação se estende a uma prosa muito profícua. Nascido em Belém do Pará, no Brasil, em 10 de agosto de 1921, onde passa seus dois primeiros anos, o autor volta a Portugal ainda pequeno para morar em uma pequena aldeia com seus progenitores, portugueses, em razão da profissão de seu pai: médico. A vivência nessa aldeia é algo fundamental para a obra de Oliveira, como ele mesmo diz no seu texto "Micropaisagem"42.

Meu pai era médico de aldeia, uma aldeia pobríssima: Nossa Senhora das Febres. Lagoas pantanosas, desolação, calcário, areia. Cresci cercado pela grande pobreza dos camponeses, por uma mortalidade

\footnotetext{
${ }^{41}$ DIONISIO, M. O Primeiro de Janeiro, 3 jan 1945 (apud TORRES, A. In: LOPES, O.; MARINHO, M., 2002, p. 210)

${ }^{42}$ Texto incluído na obra O Aprendiz de Feiticeiro.
} 
infantil enorme, uma emigração espantosa. Natural portanto que tudo isso me tenha tocado (melhor, tatuado). O lado social e o outro, porque há outro também, das minhas narrativas ou poemas publicados [...] nasceu desse ambiente quase lunar habitado por homens e visto, aqui para nós, com pouca distanciação (2004b, pp. 183-184).

Esse ambiente descrito por Oliveira faz parte de uma região de Portugal conhecida como Gândara, paisagem que vai percorrer constantemente o trabalho desse autor e "que ele profusa e profundamente 'reconstituirá' na sua obra, quer poética, quer romanesca", como observa Manuel Gusmão (1981, p. 13).

Ainda jovem, o escritor parte para Coimbra, onde se licencia em Ciências Histórico-Filosóficas no ano de 1947. Suas primeiras publicações ocorrem ainda durante a sua adolescência. Aos 16 anos, publica o conto "Terra Alheia" e o poema "Lamentação", no livro Cabeças de Barro, que escreve juntamente com Fernando Namora e Artur Varela. No entanto, segundo Manuel Gusmão (Ibid., p. 14), o autor considera, de fato, como primeiras publicações o livro de poesia Turismo (1942), que integra o sétimo número do Novo Cancioneiro, e o romance Casa na Duna, de 1943. Ambas as obras se inserem na concepção neorrealista e trazem o ambiente da Gândara, que se tornaria uma marca de sua obra, já como cenário da temática social abordada. Além disso, aparece em Turismo a forte presença da Amazônia, o que nos leva a crer, como verifica Eduardo Lourenço, que o cenário da infância do autor não lhe foi indiferente, mostrando-se, "antes de mais nada, o lugar em que a prepotência do orgânico, o triunfo universal do líquido parece sem recurso" (2007, p. 174).

Em 1945, o autor publica outra obra de poesia, Mãe Pobre. Assim como aparecem em Turismo, o segundo livro também traz as imagens que se tornaram recorrentes em sua obra. É neste volume que se encontra uma das mais conhecidas estrofes de Oliveira, na qual o sujeito poético estabelece um diálogo com a poesia:

Tosca e rude poesia: meus versos plebeus são corações fechados, trágico peso de palavras como um descer da noite aos descampados (OLIVEIRA, 1945, p. 09).

Nesses versos, a poesia, que nos surge como um interlocutor do sujeito poético, é caracterizada como "tosca" e "rude", uma possível referência à noção de algo que se apresenta como natural, ou seja, sem lapidação, sem refinamento. É, então, uma poesia rústica e também rude - a rudeza pode ser pensada como uma característica daquilo que 
não possui delicadeza, algo ríspido. Ambas as noções podem ser relacionadas à ideia de uma poesia primitiva, mais natural, menos requintada. $\mathrm{O}$ sujeito poético, que se coloca como escritor por meio do adjetivo possessivo "meus", refere-se aos versos como plebeus. Como adjetivo, esse termo significa objetivamente algo ou alguém que não é nobre, porém, figuradamente, pode sugerir uma classificação mais comum e ordinária a um determinado objeto e ser. Assim, a poesia rústica é também comum.

Esses versos aparecem caracterizados a partir da metáfora de "corações fechados", o que pode ser lido como algo que não se abre, que não expõe suas sentimentalidades algo "duro", o que se coaduna aos primeiros adjetivos dados à poesia. A metáfora do quarto verso explicita a intensidade desses trechos: "trágico peso de palavras", possivelmente em uma referência à matéria que esses versos veiculam, o conteúdo do qual eles são feitos. Tal ideia vem se confirmar na comparação que fecha a estrofe: o terrível peso desses versos é como a noite, ao chegar, aos descampados, ou seja, a situação de sofrimento e privação que uma noite - fria e longa - impõe àqueles que não têm abrigo. Essa noite não é somente o fim do dia, a madrugada, mas é, como observa Manuel Gusmão, "a situação histórica de interlocução" (1981, p. 28).

Essa estrofe, que ficou muito conhecida na obra poética de Carlos de Oliveira, é um anúncio do caminho seguido em Mãe Pobre, pois é ela que abre o livro. O poema, que será lido de forma mais completa no capítulo XX, traz a noite como um cenário de terror, trágico. Se consideramos a "noite" como o contexto da interlocução, podemos pensar na situação de horror que a Europa sofria com a experiência da Segunda Guerra Mundial. Ainda que o conflito tivesse chegado ao fim, isso se deu de uma forma extremamente trágica e assustadora para a humanidade: o ataque a Hiroshima e Nagasaki, no Japão, com bombardeamentos militares. Ademais, os portugueses observavam internamente a continuidade de governo ditatorial que se impunha pela força e opressão, e diversas comunidades e aldeias vivam numa pobreza intensificada pelo descaso do Estado com essas regiões.

O cenário da Gândara aparece em seguida na publicação Alcateia, elaborado entre 1944 e 1945, o qual foi apreendido pela censura logo após seu lançamento. Por decisão de Carlos de Oliveira, esse texto não volta a ser reeditado, mesmo com a sua morte em $1981^{43}$. Conforme aponta Gusmão (1981, p. 14), entre 1945 e 1948, o escritor integra a

\footnotetext{
${ }^{43}$ Osvaldo Silvestre observa que Carlos de Oliveira teria se debruçado em uma tentativa de reescrita de Alcateia, mas que teria desistido à beira da morte. Em nota, Silvestre indica: "Uma notícia da reescrita, operada sobre um exemplar do romance publicado, acompanhada de um fac-símile surge no número 450/1 de Vértice, 1982, p. 732-6, em secção intitulada 'Inéditos de Carlos de Oliveira', com reconstituição
} 
redação da revista Vértice e também faz algumas traduções, incluindo textos de Paul Éluard. Com Joaquim Namorado, funda, em 1948, a coleção de poesia "O Galo", onde publica seu terceiro livro, Colheita Perdida. Nessa obra, como ocorre já no livro anterior, Oliveira traz um "prolongamento" da dialética sombria entre dor (desespero) - esperança (1981, p. 14). Ainda em 1948, o autor publica o romance Pequenos Burgueses.

No ano seguinte, o autor publica Descida aos Infernos, considerado pela crítica um poema central na obra lírica do escritor. É um longo poema narrativo composto por vinte poemas que traz, como os livros até o momento, uma relação entre "uma poética de testemunho em luta contra a exploração humana e sua degradação", como observa Ida Alves (2002, p. 121), pois o poeta está sempre atento aos homens e ao mundo de que participa e para o qual sonha a conquista de uma definitiva felicidade geral" (CASTRO, 2010, p. 221), estando numa “dolorosa posição existencial” (Ibid.).

Esse aspecto de testemunho se relaciona a uma percepção do poeta sobre si como testemunha e vate ao mesmo tempo, conforme observa Eduardo Lourenço (2007, p. 167). Para ele, a poesia de Carlos de Oliveira "enraíza, aquém e para lá da intenção ideológica que superficialmente a organiza, em obsessões profundas, cuja gama toma, por vezes, reflexos perturbantes, rondando de perto os domínios obscuros e graves das imagenslimites da nossa precária condição" (Ibid., p. 168). Essa poética seria, segundo o ensaísta, de "uma natureza pessimista, tanto no sentido trivial da expressão como no reflectido" (Ibid., p. 169). Porém, nesse ponto, ocorreria um conflito essencial, "pois esse pessimismo luta por transcender-se em visão optimista do mundo, pelo menos sob o plano da História" (Ibid.). E, em nossa leitura enquanto críticos e leitores, restaria a dúvida se, em tal tensão, sobressai-se a natureza pessimista ou esse desejo otimista que o demanda.

Tal contradição - que, em alguma medida, pode ser lida como a relação de opostos complementares - tem como referência inicial um ponto bem definido: a realidade, como o próprio autor pondera: “o meu ponto de partida, como romancista e poeta, é a realidade que me cerca: tenho de equacioná-la em função do passado, do presente, do futuro; e, noutro plano, em função das suas características nacionais ou locais" (OLIVEIRA, 2004b, p. 65). Ter consciência da realidade e, de certa forma, traduzi-la para o poema ou para a ficção, levou Oliveira a ter uma concepção de que a poética tem caráter histórico, "geral, colectivo, do material da poesia, as palavras, as frases”, como explica Manuel Gusmão (1981, p. 15).

de duas páginas da nova obra. A apresentação não está assinada. In: Colóquio/Letras, 2017, mai/ago, n. 195, p. 29. 
Atentos à sua realidade, a lírica de Carlos de Oliveira e parte de seus romances trouxeram uma literatura que se preocupou com a sua própria atuação na sociedade diante de questões de exploração e alienação do homem comum. Porém, essa perspectiva aos poucos soma-se a uma visão sobre a própria criação artística, como observa Ida Alves (2000, p. 124). Segundo a autora, Oliveira

[...] cedo demonstraria compreender que a palavra literária não se curva sem insatisfação e angústia a projeto exterior, tendo que deslocar para a margem os problemas de sua própria elaboração. Por isso, a obra de Oliveira torna-se testemunho de questões fundamentais em Literatura como o problema da mimese e da referência, tensionando o "falar do mundo" com a "criação de mundos", representação e ficção. (Ibid.)

O percurso engajado, assim, seria a perspectiva até Terra de Harmonia, de 1950, e a reflexão sobre a criação da arte e do trabalho com a linguagem começaria a ser acentuado a partir dessa obra. Três anos depois, o autor lança mais uma ficção, Uma Abelha na Chuva, cujo enredo apresenta a queda da aristocracia portuguesa acompanhada pelo desenvolvimento da burguesia e seu desejo de ascensão social, ilustrando o processo da decadência de uma aristocracia rural por meio do poder de uma burguesia pouco culta.

Em 1960, o escritor volta a publicar sua poesia com o volume de Cantata, com textos que teriam sido elaborados até 1956. Rosa Maria Martelo destaca que essa obra chama a atenção de grande parte dos críticos, os quais veriam "corporizar-se, neste escasso conjunto de poemas breves, um momento de viragem na poética do autor" (1996, p. 339). É esse um livro que se difere dos anteriores pela regularidade formal dos poemas, um novo elemento entre a poética de Oliveira, de acordo com Manuel Gusmão (1981, p. 43), que se refere ao volume como um livro de passagem, justamente por esse novo caráter que ele inaugura em relação ao "modo como o poema se autorrefere [...]" (Ibid., p. 46)

Sobre o Lado Esquerdo é o livro de poesias que segue Cantata, publicado em 1968. Ele, juntamente com os dois livros seguintes de poesia, Micropaisagem (1968) e Entre Duas Memórias (1971), pode ser vistos, segundo Martelo, como "um corpo unitário" (1996, p. 372), trazendo poemas que são fortemente ligados ao trabalho poético, o que indica um momento da obra de Oliveira em que ele tem a necessidade de demonstrar o mundo de construção e desenvolvimento dos poemas, como indica Gusmão (1981, p. 50). Ainda em 1971, é publicado O Aprendiz de Feiticeiro, um livro que traz textos diversos, como depoimentos sobre a sua biografia, crônicas e reflexões sobre a escrita e o processo artístico. Nesses questionamentos, Carlos de Oliveira apresenta uma visão não 
somente sobre a arte mas também sobre o seu próprio trabalho artístico, o que é ilustrado pelos ensaios "Almanaque Literário", "O Iceberg" e "Micropaisagem".

Nesse percurso poético, é-nos fundamental ressaltar que Oliveira foi "um dos leitores mais atentamente crítico dos seus livros" (MARTELO, 1996, p. 15), e a maneira como ele entendia a criação poética - "não considerando os textos publicados como necessariamente concluídos" (Ibid.), ou seja, eram suscetíveis a revisões e reelaborações -, levou-o a reorganizar sua obra poética em dois momentos. Em 1962, sob o título Poesia, o autor publicou todos os seus livros já lançados, excluindo da coletânea seu primeiro volume, Turismo. Alguns anos mais tarde, em $1976^{44}$, ele volta a rever sua lírica e publica Trabalho Poético, no qual indica que seu conjunto poético deveria limitar-se ao que foi publicado nesse volume. Nesse livro, Turismo volta a ser contemplado, sofrendo, porém, muitas mudanças ${ }^{45}$. Também aparece Pastoral, como um conjunto inédito de poemas redigidos até 1971. Seus poemas trazem uma ausência de organização macroestrutural, diferente do que ocorre com alguns livros anteriores, como Micropaisagem.

Na ficção, Oliveira publica em 1978 seu célebre romance Finisterra: paisagem e povoamento, o qual se distancia da abordagem materialista histórica presente nos romances anteriores. Sobre o livro, Herberto Helder ${ }^{46}$ nos diz: "[Finisterra] proposto como romance, é antes uma alegoria ficcionalmente articulada que pode ser lida na perspectiva de uma espécie de cartografia imaginária do autor, constituindo assim a melhor introdução ou o melhor comentário à sua obra". O livro traz a temática da decadência de uma família no já conhecido cenário gandarês. No entanto, o texto nos aparece numa perspectiva distinta e torna-se, como observa Manuel Gusmão (2009, sem p.), abstrata, geométrica e alegórica. $\mathrm{O}$ ensaísta ainda ressalta que o subtítulo "paisagem e povoamento" sugere um processo duplamente dialético.

Tanto na ficção como na poesia, a questão da escrita e da reescrita em Carlos de Oliveira surge como um desafio para a crítica e para a análise desses textos, uma vez que, segundo Martelo, "reescrever significa inscrever no texto um outro momento de escrita, outro entendimento do mundo, outras opções estético-literárias que não as iniciais" (1996, p. 15). Nesse sentido, sua obra se manteve em constante movimento e em constante

\footnotetext{
${ }^{44}$ Conforme Rosa Maria Martelo nos indica, a última versão de Trabalho Poético dataria de 1981, em um volume único (Cf. MARTELO, R., 1996, p. 16, nota 2).

${ }^{45}$ As mudanças relativas aos livros e aos poemas serão mais bem elaboradas nos capítulos adiante.

${ }^{46}$ Palavras de Herberto Helder ao incluir Carlos de Oliveira na sua antologia Edoi Lelia Doura: antologia das vozes comunicantes da poesia moderna portuguesa. Lisboa: Assírio Alvim, 1985.
} 
reflexão, "relacionando-se dinamicamente com diferentes tendências da poesia portuguesa contemporânea" (1981, p. 20), conforme afirma Gusmão.

Em torno das críticas sobre a obra de Oliveira, muitos autores questionam se ele permanece neorrealista ou se sua obra se expande para outros caminhos. É, para nós, importante conhecer a forte presença e participação do autor na elaboração do movimento neorrealista, em cujo grupo era tido como "a consciência crítica" ${ }^{47}$, nas palavras de Gastão Cruz. Esse movimento promove, a partir da sua existência, uma reflexão sobre a arte e sobre a função do escritor, temática essa que aparece intensamente ligada à sua obra e ao processo minucioso de criação artística de seu "trabalho", seja ele poético, seja romanesco.

\section{4. "A Poesia é só uma" - o aparecimento dos Cadernos de Poesia}

O conflito entre presencistas e o neorrealistas colocou em relevo, como observamos nas páginas anteriores, o questionamento sobre a função do autor e o próprio papel da poesia inserida em sua realidade, apesar da ressalva feita sobre alguns pontos de contato entre os grupos. Ora, diante de tal acalorada tensão era esperado que surgissem escritores que buscassem um apaziguamento dessa situação. É nessa concepção que surgem, a partir de 1940, os Cadernos de Poesia, cuja duração foi de catorze anos. Em seu lançamento, a revista é classificada como "publicação literária em fascículos", conforme observa Luís Adriano Carlos (In: LOPES; MARINHO, 2002, p. 235), pois, dessa maneira, buscou-se disfarçar a sua perspectiva política e ideológica - afinal, os escritores enfrentavam no período forte cerceamento da censura ditatorial.

Os Cadernos buscam oferecer à tensão no âmbito literário uma resposta que pudesse integrar o lado estético e ideológico em torno da poesia e da criação artística, demonstrando uma visão ligada à "ética", isto é, uma conciliação entre os lados do conteúdo e da forma na literatura. As publicações ocorreram em quinze números, lançados ao longo de catorze anos. Os fascículos, porém, não trouxeram necessariamente uma temática linear durante sua existência. A revista apresentou-se em três séries distintas: a primeira série, com cinco fascículos, entre os anos de 1940 e 1942, configurase, segundo Luís Adriano Carlos, como uma "plataforma superativa" (In: LOPES; MARINHO, 2002, p. 236), ou seja, entre os lados da polêmica "poesia pura" e "poesia

\footnotetext{
${ }^{47}$ Informação extraída de "Carlos de Oliveira: o intelectual, a política e a literatura", de Benjamin Abdala Júnior. In: Colóquio/Letras, 2017, mai/ago, n. 195, p. 107.
} 
social”, os colaboradores lançaram-se sob o lema “A Poesia é só uma!”. Conforme analisa Helena Malheiro,

A maiúscula com que o seu nome se sublinhava [Poesia] era, desde logo, o indício da dignidade que lhe conferiam, privilegiando-a, de forma inequívoca, em relação às outras formas literárias. Os Cadernos pretendiam assim ultrapassar a absurda e extremista oposição entre o individualismo descomprometido dos presencistas e a militância social marxista dos neorrealistas, em prol de uma ética irrepreensível e de valor autônomo da pura essência da poesia e da arte (2008, p. 279).

Em 1958, Jorge de Sena afirma que a primeira série de Cadernos "pretendeu ser, e foi, apenas um repositório antológico de todas as tendências do tempo, que então mutuamente se negavam, desprezavam ou devoravam, para, ao lado e sobre esse repositório, propor uma plataforma ética e não estética de entendimento" ${ }^{48}$ Assim, em seu primeiro momento, a publicação pretendeu restabelecer a ética na poesia, sugerindo que as diferentes posturas e visões dialogassem numa valorização estética e ideológica da criação poética.

A segunda série da publicação é inaugurada com um texto de Jorge de Sena, em maio de 1951, em que se afirma o viés ético dos Cadernos de forma mais aprofundada, porém, conforme verifica Luís Adriano Carlos (In: LOPES; MARINHO, 2002, p. 237), o caráter antológico é suprimido, e o escritor, que aparece como organizador, exprime nessa fase sua "visão testemunhal da expressão poética" (Ibid., pp 237-238), a poesia como uma "plataforma ética", ou seja, uma visão que exprime "uma orientação comprometida com a realidade, sem prejuízo da qualidade intrínseca” (Ibid., p. 238). Nesse momento, assim, procura-se estabelecer a criação lírica como comprometimento intencional e relacional: "um compromisso firmado entre ser humano e o seu tempo, entre uma personalidade e uma consciência sensível do mundo, que mutuamente se definem". ${ }^{4}$

Entre 1952 e 1953, a terceira série dos Cadernos reafirma o posicionamento ideológico da fase anterior, encerrando-se no fascículo de número quinze. No volume 13, exprime-se a ideia de que "nenhum compromisso responsável pode ser firmado sem perfeita lucidez, sem ampla compreensão, sem indefectível independência”, o que torna a "liberdade essencial e originária imanente à poesia, que é servida, não serve". ${ }^{50} \mathrm{~A}$ edição seguinte é dedicada a Teixeira de Pascoaes, na qual Sophia de Mello Breyner

\footnotetext{
${ }^{48}$ SENA, J., apud CARLOS, L. In: LOPES, O.; MARINHO, M., 2002, p. 236.

49 Ibid., p 238.

${ }^{50}$ Cadernos de Poesia, nㅇ13, 3a série, Lisboa, 1952, apud CARLOS, L., op. cit., p. 239.
} 
Andresen publica um artigo afirmando que ele seria "um poeta à margem de tudo quanto não seja a própria poesia". 51

$\mathrm{Na} 15^{\mathrm{a}}$ publicação, os colaboradores trazem "um manifesto no qual se afirma a aliança entre a poesia e a consciência de dignidade humana”. O fim dos Cadernos acontece, entretanto eles se configuram como um veículo em que "as colaborações, distintamente expressas na esfera literária, puderam dialogar entre si, mantendo suas respectivas singularidades artísticas conservadas" ${ }^{\prime 52}$ e promovendo uma reflexão acerca do fazer poético na qual não se dicotomizasse em extremos a forma e o conteúdo no processo literário.

\subsubsection{Sophia de Mello Breyner Andresen: a apreensão do real na poesia}

É esse o contexto em a poeta Sophia de Mello Breyner Andresen, nascida em 6 de novembro de 1919, no Porto, surge e faz sua primeira publicação, a qual ocorre no primeiro fascículo dos Cadernos de Poesia, com o poema que, posteriormente, é editado no primeiro livro da autora Poesia, de 1944, com o nome "Senhor". A autora elabora seu projeto poético inserida em um contexto de cerceamento político assim como Carlos de Oliveira, afinal, se considerarmos aproximadamente o início da década de 1940 como o surgimento de ambos os escritores, verificamos que o governo ditatorial já estava no poder havia cerca de 14 anos.

Luís Adriano Carlos (2002, p. 237) observa que os Cadernos de Poesia traziam uma relação ampla com a produção poética do período, mantendo um diálogo com a poesia inglesa e com o Surrealismo francês e com autores como Goethe, Teixeira de Pascoaes, Rimbaud e o grupo de Orpheu. Esses nomes, como indica Clara Rocha, representam influências marcantes na obra de Sophia Andresen desde suas primeiras publicações, nas quais se percebe a intensa presença do mito de Orfeu, "situando a autora na linhagem de poetas como Hölderlin e Rilke, que celebraram a poesia como uma forma de possessão e o entusiasmo poético como um ser em Deus" (1996, p. 36);

Em Poesia, Sophia Andresen inicia um itinerário poético o qual "se esboçou com nitidez, contendo incipientes, quase todos os elementos que vão constituir-se como característicos do seu mundo", de acordo com Maria de Lourdes Belchior (1986, p. 36). Tais elementos, como o mar, o vento, o sol, a luz e as casas de muros caiados, apontam para uma concepção de poesia muito peculiar trilhada pela autora, que construiu um

\footnotetext{
${ }^{51}$ ANDRESEN, S., Cadernos de Poesia, no14, 3ạ série, Lisboa, 1953, apud CARLOS, L., op. cit., p. 239.

52 Ideia apresentada em nossa dissertação de mestrado NAHAS, N., 2015, p. 37.
} 
projeto poético fortemente vinculado ao mundo do real. Essa poesia cria-se e estrutura-se a partir "de uma busca no espelho do mundo e num mundo de evidências aurorais", como a "evidência elementar do vento, da bruma, do mar, do jardim exposto e secreto [...]", nas palavras de Eduardo Lourenço (In: ANDRESEN, 1975, p. II), em seu célebre texto "Para um Retrato de Sophia".

Tal "espelho do mundo" relaciona-se à ideia de que a poética andreseniana vai buscar nos elementos da realidade sua construção e sua existência, e a autora define sua visão sobre a poesia no conhecido ensaio "Poesia e Realidade" 53 , no qual elabora a ideia de que a Poesia - com "p" maiúsculo - é "a própria existência das coisas em si, como realidade inteira [...]" (Idem, 1960, p. 53), ou seja a própria realidade dos elementos do mundo. Já o termo com “p” minúsculo define-se como a ligação do homem com a Poesia, isto é, "a poesia é a relação pura do homem com as coisas" (Ibid.). No projeto andreseniano de poética, esses conceitos são intrínsecos um ao outro em uma ligação consubstancial. Assim, como analisa Paola Poma, essa lírica "[...] destoa da lírica portuguesa por trazer à tona não só a materialidade do mundo, mas também a sua harmonia - fusão entre a natureza, os deuses e os homens - como possibilidade" (2011, p. 107).

Após sua colaboração com os Cadernos até o começo dos anos 1950, Sophia Andresen participa de outras publicações, como em Unicórnio, Atlântico, Árvore, Távola Redonda - Folhas de Poesia, entre outras. Nesse período, ela publica seu segundo livro, Dia do Mar, em 1947, no qual o elemento "mar" vai assumir "uma presença genesíaca e purificadora" (BELCHIOR, 1986, p. 36) que será presente em toda a sua obra. A noção de "gênese", de origem, será importante na sua construção poética, pois ela remete a um tempo anterior em que o homem e o mundo estavam em acordo, ligados um ao outro.

Durante a década de 1950, publica três livros de poesia: Coral (1950), No Tempo Dividido (1955) e Mar Novo (1958) e, nesse período, começa a se envolver de forma mais ativa em questões políticas ligadas a Portugal, colaborando com a oposição ao Estado Novo. Em 1957, participa da campanha do militar Humberto Delgado, o qual se candidata à presidência buscando opor-se ao regime ditatorial, porém sem sucesso. ${ }^{54}$ Em No Tempo

\footnotetext{
53 Ensaio publicado em Colóquio - Revista de Artes e Letras, 1960, pp. 53-54.

${ }^{54}$ Humberto Delgado perde nas eleições em razão de fraude eleitoral efetuada pelo governo do Estado Novo. Ele, então, passa a ser perseguido pela PIDE constantemente, o que o leva a pedir exilio político no Brasil, onde passa a residir. Em 1962, Delgado volta a opor-se numa tentativa de golpe militar, que também fracassa. Três anos mais tarde, buscando regressar a Portugal de forma não oficial, pois visava a um encontro com opositores do regime, ele é intercedido por oficiais da PIDE e é assassinado, conforme indicamos na dissertação de mestrado NAHAS, N., 2015, p. 40.
} 
Dividido e Mar Novo, segundo Belchior, passa-se a verificar uma cisão temporal que marca a lírica andreseniana entre um momento anterior - aquele da origem, da ligação e um momento de ódio e de ameaça (1986, p. 38), expressos pela poeta, muitas vezes, no uso da palavra "nojo". Essa dicotomia é vista por muitos críticos literários como uma expressão de uma consciência política que Sophia Andresen ganhava.

O tríptico que abre No Tempo Dividido apresenta a reflexão da autora sobre dois aspectos que se tornam marcantes em sua obra: a dualidade do tempo cindido e o não reconhecimento de sua nação: “A memória longínqua de uma pátria / Eterna mas perdida e não sabemos / Se é passado ou futuro onde a perdemos". Uma leitura breve dos versos ${ }^{55}$ nos indica uma voz poética que se torna coletiva - que fala em nome de um povo que já não reconhece sua pátria - e que, de certa forma, perdeu suas lembranças de um passado, o qual pode ser lido como o grande passado português, dos impérios e das conquistas, e também já não pode ver o futuro de sua nação. Nesses três versos, ocorre a expressão de uma voz poética que se vê cindida, pois ao mesmo tempo em que busca a religação entre o homem e o mundo, o presente mostra-se oposto a isso, mostra-se dividido, isto é, um tempo no qual essa união já não é possível. Nesse livro, “o sujeito evolui da pura embriaguez temporal, densa e totalizante, para uma consciência ontológica que lhe permitirá reconhecer-se como entidade trágica". 56

Essa visão estende-se e intensifica-se em Mar Novo, livro no qual "se desenha nítido o tempo dividido como tempo de ódio e de renúncia. [...] Este tempo dividido opõese radicalmente ao tempo absoluto do seu desejo" (BELCHIOR, 1986, p. 39). Nesse âmbito, podemos pensar que a poesia surge como a busca por esse tempo antigo e como a denúncia do tempo presente, o que nos indica o poema que se segue:
A memória de ti calma e antiga
Habita os meus caminhos solitários
Enquanto o acaso vão me oferece os vários
Rostos da hora inimiga
Nem terror nem lágrimas nem tempo
Me separarão de ti
Que moras para além do vento (ANDRESEN, 2011, p. 317)

O tempo passado - presentificado pela palavra "memória" - está associado às qualidades "calma" e "antiga" e se opõe, por meio do caminho solitário, ao momento presente, em que ocorre o "acaso vão" que oferece os "rostos da hora inimiga". Sendo assim, a cisão

\footnotetext{
55 Uma leitura mais completa desse poema é feito em NAHAS, N., 2015, p. 39.

${ }^{56}$ Ana Maria Pereira Soares. O tempo na poesia de SMBA: Imanência, Ruptura, Testemunho. Tese de doutorado, 2000, p. 43 apud MALHEIRO, H., 2008, p. 77.
} 
estabelece-se: o presente é o período da ameaça, da face do inimigo, que promovem o terror e a lágrima. E o passado é o tempo antigo, da memória, o tempo que contrasta com o presente por ser calmo, um tempo que não separa, e sim une.

É neste livro que se publica o famoso poema iniciado pelo dístico "Este é o tempo / Da selva mais obscura", lido como uma metáfora do contexto político do momento no qual Sophia Andresen se inscrevia, corroborando a visão dos críticos de que a poeta passara a trazer de modo mais constante aspectos sociopolíticos ao seu conjunto de temas líricos. A autora reconhece uma natureza de resistência e combate nesse poema ao inserilo na antologia Grades $^{57}$, de 1970, na qual são escolhidos poemas de perspectiva claramente política, e por isso muitas bibliografias da autora trazem o subtítulo "antologia de poemas de resistência" a esse conjunto.

A perspectiva de um presente "de nojo", de escuridão e de ameaça e a demanda de valores éticos presentes na escrita andreseniana se torna mais explícita na década de 1960, com a publicação de Livro Sexto e dos Contos Exemplares, no ano de 1962. Apesar de gêneros textuais distintos, ambas as obras intensificam essa noção de "tempo dividido". Em uma carta endereçada a Jorge de Sena, Sophia Andresen relata que o "mundo da Poesia, do Dia do Mar, do Coral morreu e o mundo do Mar Novo foi ultrapassado" (ANDRESEN; SENA, 2010, p. 34), fazendo referência a seus livros anteriores. Nesse momento, ela publicava seu livro O Cristo Cigano, em 1961, e já exprimia um questionamento sobre o porquê escrevia poesias (Ibid., p. 35).

Os críticos da obra andreseniana costumam concordar que, a partir de Livro Sexto, "as preocupações sociais se tornam mais prementes", como afirma Clara Rocha (In: MACHADO, 1996, p. 37). Porém, podemos verificar esse pensamento em momentos anteriores a esse livro. Segundo Poma, ainda que essa poética busque a possibilidade de harmonia entre os elementos do mundo, isso não significa que estamos diante de uma poesia "apaziguada com o universo, nem mesmo que sua poesia seja feita de ausência de tensões ou desprovida do viés político tão presente em grande parte dos poetas que viveram o quase meio século de ditadura salazarista" (2011, p. 107). É importante notar que essa lírica incorpora a tal denúncia dos tempos de horror - o que tornaria sua poesia politicamente comprometida - à cisão temporal já explicitada na sua obra, na qual "urge de facto, explícita ou aludida, a necessidade de reconstituir o intervalo entre universo mítico e universo real [...]), como observa Giulia Lanciani (2011, p. 09). Sendo assim, a

\footnotetext{
57 Uma apresentação mais completa sobre essa antologia foi desenvolvida por nós na dissertação de mestrado NAHAS, N., 2015, pp. 45-51.
} 
fissura entre o tempo antigo e original - de ligação entre o mundo e o homem - é anunciada e intensificada pelas imagens da miséria, pobreza e exploração do povo e os terrores e as ameaças políticas do momento pelo qual Portugal passava.

Ainda na década de 1960, temos a publicação do livro Geografia (1967) e da Antologia (1968), prefaciada por Eduardo Lourenço, em texto no qual afirma a bela imagem que a poesia andreseniana é "mistério repassado de claridade" (In: ANDRESEN, 1978, p. I). E tal claridade "atinge" também a linguagem dessa poesia, o que é observado por Eduardo Prado Coelho (1980, p. 109), mostrando que esse é mais um aspecto da relação que essa lírica busca com o antigo, o primordial, o essencial. Essa clareza há de contrastar, evidentemente, com a exposição do real, do tempo da realidade da autora, que enfrentava ideologicamente, como outros escritores, uma forte opressão do Estado imposta pela censura.

Na década seguinte, Sophia Andresen publica a já referida antologia Grades e, em 1972, o livro Dual, no qual traz uma perspectiva sobre o país de desunião, de fragmentação e quase de não pertencimento. Esse "é um livro amadurecido, onde topamos com poemas onde os valores éticos se exprimem em beleza e plenitude [...]" (BELCHIOR, 1986, p. 41). É também muito clara a ligação da autora com o universo grego neste livro, em cuja civilização Sophia Andresen "procura um conjunto de valores perdidos: a inteireza, a harmonia, a justiça”, como analisa Clara Rocha (In: MACHADO, 1996, p. 37). A justiça será, como veremos a partir do capítulo 3, um valor buscado pela autora, pois, "no tempo dividido", ela já não observa esse valor. Assim, vemos uma poética que apresenta seu projeto em diálogo com uma forte consciência política.

Cinco anos mais tarde, em 1977, a autora publica O Nome das Coisas, o qual traz, novamente, o forte teor de denúncia e combate. Convém observamos que esse poema e os demais estão inscritos em um contexto assolado por uma guerra colonial entre Portugal e os países africanos que eram então de seu domínio e a transição política de Salazar para Marcello Caetano no início dessa década, após um acidente que causou naquele trombose cerebral em 1968. Esse momento de tensões e guerras se inserem no livro, como no poema “Guerra ou Lisboa 72", em que fala sobre um homem, provavelmente um soldado, que "Partiu vivo jovem forte", porém "Voltou bem grave e calado / Com morte no passaporte" (ANDRESEN, 2011, p. 606). Essa perspectiva política integra-se ao título muito evidente do livro, pois ao nomear "a coisa", inscrevemo-la no mundo, ela se torna real, ela se torna presente. 
É também em O Nome das Coisas que surge o emblemático poema "25 de Abril", o qual se refere à Revolução dos Cravos, movimento que põe um ponto final na ditadura militar de Portugal. O poema diz:

Esta é a madrugada que eu esperava

O dia inicial inteiro e limpo

Onde emergimos da noite e do silêncio

E livres habitamos a substância do tempo (ANDRESEN, 2011, p. 618)

$\mathrm{Nele}^{58}$, a data da revolução é associada àqueles elementos tão buscados pela autora em sua poética: o tempo primordial, de inteireza e claridade, limpeza. O momento, tão esperado pela voz poética, evoca a possibilidade de se reerguer "da noite e do silêncio" para se habitar "livre", uma vez que esse movimento trouxe o fim do tempo de opressão, de medo e de ameaça. O tempo não seria mais de renúncia, seria de integração, de clareza, de união. A autora reconhece que essa data foi "um dos momentos de máxima alegria" (1986, p. 74) em sua vida, pois revela-se a oportunidade de construção política do país por meio da democracia.

Nesse livro, é publicado o ensaio "Poesia e Revolução"59, no qual Sophia Andresen estabelece uma clara relação entre o fazer poético, a poesia e a política. Para a autora, a poesia é naturalmente política, porque é a implicação do homem no real. Assim, o poeta, ao buscar uma conexão verdadeira com os elementos do mundo, busca, consequentemente, uma ligação com os outros homens. Ao buscar a justiça desse vínculo, o poeta elabora sua poesia, que é também política. A associação de revolução e de poesia ainda aparece no poema que leva este nome, em que, entre seus versos, a voz poética afirma em uma comparação implícita que revolução é "Como página em branco / Onde o poema emerge" (ANDRESEN, 2011, p. 619).

Na década seguinte, Sophia Andresen publica mais dois importantes livros de poesia. Navegações, de 1983, traz, como observa Belchior, "a temática do mar, em perspectivas de aventura do ser e de aventura de um povo" (1986, p. 42), e seria uma “epopeia do ver” (Ibid.). O mar aparece como um espaço de descobrimento, mas também de religação, do homem e os elementos do mundo e também do tempo - aquele tempo já dividido que percorre sua obra. Em 1989, a autora publica Ilhas, em que traz o poema “Carta(s) a Jorge de Sena”, o qual demonstra a delicada e afetiva relação entre ambos os

\footnotetext{
${ }^{58}$ Uma leitura mais detalhada sobre esse poema foi desenvolvida por nós na dissertação de mestrado NAHAS, N., 2015, pp. 44-45.

${ }^{59}$ ANDRESEN, S., 1977, pp. 77-80.
} 
autores, mesmo com a distância do exílio de Sena. No poema, a autora o define como "Legítimo português de novecentos" - em referência aos homens que precisaram ou optaram por se autoexilar durante os conflitos dos anos 1900 e dos governos autoritaristas que lideraram a Europa naquele período. E ainda nessa década, em 1984, que o conhecido livro de contos História da Terra e do Mar é publicado.

Nos anos 1990, são publicados os livros Musa, em 1994, e O Búzio de Cós e Outros Poemas, de 1997. O termo "musa" configura-se como uma referência muito importante à obra andreseniana, trazendo a imagem das divindades da cultura grega que, por meio de suas palavras, presentificavam o mundo, a realidade. Esse significado vai se relacionar de forma muito íntima com a visão de Sophia Andresen sobre as palavras que criam o poema, o qual torna o real presente. Em Musa, esse universo grego está fortemente inserido, com imagens sobre as ménades, as parcas e o casal que é caro à lírica andreseniana: Orpheu e Eurydice.

O Búzio de Cós e Outros Poemas traz imagens recorrentes de Sophia Andresen, como o universo da praia, a casa e elementos da cultura greco-romana. A quadra "Homero" apresenta uma reflexão essencial sobre o fazer poético que percorre essa lírica em todo seu itinerário. O poema diz:

Escrever o poema como um boi lavra o campo

Sem que tropece no metro o pensamento

Sem que nada seja reduzido ou exilado

Sem que nada separe o homem do vivido (ANDRESEN, 2011, p. 814)

Observamos, nesse breve texto, a relação que a poeta estabelece entre o poema e o real, de forma disciplinada - como o boi a lavrar o terreno -, sem que a forma fixa mostre-se como um obstáculo àquilo que deve ser dito, pois para a autora o poema surge, é-lhe dito e a ela cabe adaptar as arestas, mas não sufocar o real com a imposição formal. Para ela, "quando há apenas relação com uma matéria há apenas artesanato" (Ibid., p. 839), e não um poema em si. Este é o espaço em que o real se presentifica, por isso o poeta deve escrever sem exilar ou reduzir, sem separar o homem da sua vivência, da sua própria realidade, que é a própria definição de poesia para Sophia Andresen, uma vez que "É esta relação com o universo que define o poema como poema, como obra de criação poética" (ANDRESEN, 2011, p. 839), conforme explica a autora em seu ensaio "Arte Poética II".

Aliás, os ensaios de Sophia Andresen trazem a seus leitores uma imersão no pensamento da autora sobre a poesia e o fazer poético, oferecendo uma ampliação sobre 
a leitura de seus poemas. Temos, por exemplo, as célebres "Artes Poéticas", conjunto de cinco textos em que Sophia desenvolve seu pensamento acerca de seu projeto poético. A primeira "Arte Poética" é publicada em dezembro de 1962 na revista Távola Redonda e, no ano seguinte, é publicada a segunda. As duas são republicadas em Geografia (1967). “Arte Poética III" é, talvez, a mais célebre entre elas, e nela a autora elabora de forma muito detalhada e poética de que forma seu olhar objetivo a levou a apreender a poesia como "presença das coisas". Nela também a autora fala sobre a busca pela relação de harmonia e totalidade entre os elementos do mundo, vinculação na qual se insere o homem. A partir disso, ideias sobre a justiça da poesia e na poesia são abordadas, e podemos ler a seguinte afirmação "[...] o poeta é levado a buscar justiça pela própria natureza da sua poesia" (Ibid., p. 841).

É com base em tal ideia que propomos neste trabalho a leitura do projeto poético de Sophia Andresen, buscando pensar de que maneira surge e se molda o pensamento social que aparece tão fortemente no decorrer dessa lírica. Temos uma autora que partirá de uma concepção peculiar de política e de poesia e busca, ao longo de seus poemas, de seus contos e de seus ensaios, a religação do homem com o seu mundo, vínculo esse perdido há muito tempo. A poesia, assim, é para ela, "uma moral” (Ibid.). Nesse sentido, procuraremos compreender e explanar de que modo o "fazer político" vai se inscrever no projeto poético andreseniano ou de que maneira vai, talvez, ser parte essencial deste.

A partir dessa análise, pretendemos estabelecer uma leitura comparativa das obras da autora com os textos de Carlos de Oliveira, com o intuito de analisarmos de que forma eles se aproximam da literatura de cunho social. Vimos que os dois escritores procuram partir da realidade para conceber suas obras e nela se encontram as relações que homem estabelece com seus semelhantes. Assim, buscaremos verificar de que maneira temas como a relação entre classes, a desigualdade socioeconômica, a miséria decorrente dela e a subjugação de um grupo desfavorecido a uma camada abastada aparecem nessas poéticas, contemplando as características individuais de cada autor. Em Oliveira, vamos estabelecer uma leitura a partir da sua relação com o Neorrealismo, considerando se a sua lírica e a sua prosa configuram-se, de fato, como um desvio desse movimento, algo observado por muitos críticos, como observa Torres. Na escrita andreseniana, buscaremos abranger os diálogos que a autora estabelece com o pensamento cristão e a cultura helênica, os quais oferecem elementos preponderantes em sua produção. Tentaremos, portanto, observar de que modo essa temática reflete e é refletida na trajetória literária de ambos, mostrando suas aproximações e seus distanciamentos. 


\section{O (neo) realismo humanista na prosa de Carlos de Oliveira}

"Pensando bem não tenho biografia" (OLIVEIRA, 2004b, p. 163). É com essa frase enfática que Carlos de Oliveira responde a uma carta de uma estudante de literatura que lhe pedira dados biográficos. $\mathrm{O}$ autor prossegue sua resposta, presente no ensaio " $\mathrm{O}$ Iceberg", explicando justamente o que chamará de "complexo do iceberg":

Pensando bem não tenho biografia. Melhor, todo o escritor português
marginalizado sofre biograficamente do que posso denominar
complexo do iceberg: um terço visível, dois terços debaixo de água. A
parte submersa pelas circunstâncias que nos impediram de exprimir o
que pensamos, de participar da vida pública, é um peso (quase morto)
que dia a dia nos puxa para o fundo. Entretanto a linha de flutuação vai
subindo e a parte que se vê diminui proporcionalmente. (Ibid.) O iceberg é uma massa de gelo formada por água doce que flutua no oceano, de água salgada. Justamente pelas diferenças específicas entre as massas da água em estado sólido e líquido, o corpo flutua, porém somente $10 \%$ de seu volume é visto. Apesar de haver a flutuação, a água salina possui uma massa específica maior que a do gelo, o que mantém cerca de $90 \%$ do volume do iceberg imerso. Em uma analogia, Carlos de Oliveira analisa que a biografia do escritor português é algo que se observa apenas superficialmente. Mas, para além dessa superfície, existe uma base larga que é puxada para baixo, mantendo-se sempre oculta. Ele ainda afirma que biografar a vida de alguém é algo que foi negado aos escritores.

Se pensarmos no contexto em que Oliveira escreve, poderíamos facilmente relacionar sua fala à situação sociopolítica de Portugal da primeira metade do século XX, momento marcado pelo governo comandado por Salazar, no qual havia o intenso trabalho da polícia política, a PIDE, em controlar e cercear o pensamento dos intelectuais, agindo como a água salgada, ocultando a verdadeira expressão dos artistas. Ao recolhermos dados da vida de Carlos de Oliveira, vamos nos deparar com algumas datas e acontecimentos, sim. Porém, são informações vistas por alto, pois aquilo que realmente importa, aquilo que é profundo, é negado a esses indivíduos pela limitação da sua produção e até de sua liberdade.

Ainda que o cerceamento político-intelectual seja uma força que o oprima, como sua metáfora do iceberg nos sugere, sabemos de um dado biográfico de sua vida que se tornou essencial para sua obra: sua infância na Gândara portuguesa. Como vimos em uma citação do próprio autor no capítulo anterior, essa região não somente o tocou como o tatuou. Mas ela não surge como um cenário apenas da escrita de Oliveira, ela é muito 
mais. Ela é a paisagem e, ao mesmo tempo, o alicerce de um pensamento, de imagens, de personagens e de questões sociais das quais vai nascer grande parte da escrita desse autor, sobretudo no que tange aos seus romances. Sua vivência permitiu-lhe ser marcado por aspectos desse ambiente, e, da matéria da memória, ele forja sua lírica e sua prosa.

Entre 1943 e 1978, Carlos de Oliveira publica cinco romances que nos permitem um contato e uma observação muito próxima do ambiente específico gandarês. Localizada entre a região central e o Norte de Portugal, a Gândara refere-se a "terrenos em que medram plantas agrestes" ${ }^{60}$, onde nasce a charneca - planície inundada que se aproxima do pântano. É um espaço geográfico onde predominam áreas arenosas, muitas vezes improdutivas. "Lagoas pantanosas, desolação, calcário, areia” (OLIVEIRA, 2004b, p. 183), esses são os elementos que constituem a memória do autor sobre esse território segundo suas próprias palavras no já citado ensaio "Micropaisagem". A eles, ainda podemos somar o intenso estio que domina o clima desse local.

Vitor Viçoso observa que tal cenário se constitui como um leitmotiv em todas as suas obras, desde a prosa à poesia, porém não apensas como um ambiente em que se decorre a ação, e sim em um processo de "permanente reinvenção a partir dos seus materiais imaginários" (2011, p. 160), definindo também "homologamente a especificidade de sua escrita (vocabulário e sintaxe). Para o crítico, esse material da memória transita do real para o imaginário e se redistribuem nas obras "numa peculiar cartografia poética" (Ibid.). Ele ainda observa que retomar essa paisagem não é um ato nostálgico relativo a uma idade de ouro da infância, e sim "uma descida a um espaço matricial de desolação, carência e brevidade" (Ibid., p. 61).

A constante presença de tal paisagem na obra ficcional e poética de Oliveira leva Alexandre Torres a utilizar a expressão "Tetralogia da Gândara” (1967, p. 249) ao referirse aos romances do autor, nomeando os quatro primeiros: Casa na Duna (1943), Alcateia (1944), Pequenos Burgueses (1948) e Uma Abelha na Chuva (1953). O crítico, em um ensaio que traz a expressão como nome, ressalta que tais obras apresentam uma interligação não somente por situarem-se na mesma terra mas também por dialogarem entre si por meio de referências e personagens. Além disso, esse conjunto indica uma característica importante: foca-se, de forma geral, na pequena-burguesia ou na elite rural, o que colocou seu autor na posição de "incompreendido" do Neorrealismo segundo Torres (1967, p. 249).

\footnotetext{
${ }^{60}$ Verbete "gândara" in: Dicionário Eletrônico Houaiss da Língua Portuguesa.
} 
Esse adjetivo refere-se, em princípio, ao fato de o Neorrealismo, visto de maneira mais ortodoxa, defender que a obra de arte deve abordar questões sociais relativas a classes oprimidas, como o homem simples camponês ou proletário. De fato, se considerarmos outro importante romance neorrealista, Gaibéus (1939), de Alves Redol ${ }^{61}$, identificaremos facilmente o grupo social não abastado como protagonista da narrativa, os camponeses que vivem em condições precárias na região do Ribatejo. Os romances que melhor respondiam a uma estética neorrealista trouxeram, como observa Carlos Reis (1981, p. 30), o enfoque nas classes sociais mais desfavorecidas, buscando, por meio da narrativa, a denúncia de condições de miséria e exploração vividas por tais grupos. Ainda que seja visto por parte da crítica como um distanciamento da ortodoxia neorrealista, Eduardo Lourenço ressalta que Oliveira desviou para sempre o centro da literatura portuguesa para "a condição humana, simples, directa e concreta" dos camponeses e da elite rural (1945 apud SILVESTRE, 2001, p. 344).

O Neorrealismo, de forma mais ampla, propõe um romance que obedecia a "um modelo de pragmatismo que lhe comandava a estruturação narrativa" para cumprir com o objetivo "de conscientização e de luta por transformações sociais", como observa Lélia Duarte (1998, p. 91). Tal discurso solicitava um registro claro e direto para que pudesse ser compreendido pelos "vencidos / injustiçados da vida que não tinham como aspirar à condição de heróis no sentido tradicional” (Ibid.). O autor seria, então, a voz da denúncia, e seu texto, suscitador do combate e da reivindicação por melhorias sociais, atribuindo ao escritor uma visão quase pedagógica e demandando-lhe uma narrativa nítida que desse voz aos mais fracos. Segundo Gonçalo Duarte, "Dando voz às classes que geralmente não tinham acesso ao discurso, os escritores neorrealistas pretendiam prestar um serviço comunitário que compreensivelmente se integrava num projeto humanista mais largo [...]” (2008, p. 56). A arte, desse modo, cumpriria seu propósito político e humanitário aos olhos do movimento.

Carlos de Oliveira, sob tal perspectiva, é visto, conforme explica Alexandre Torres (1967, p. 249), como um autor que se distancia da proposta neorrealista. De fato, sua "tetralogia da Gândara" vai centrar-se na estrutura social baseada na elite gandaresa, o que é muito evidente no primeiro romance, Casa na Duna (1943), e no último desse grupo, Uma Abelha na Chuva (1953). Além disso, Pequenos Burgueses (1948) convoca

\footnotetext{
61 É interessante observar que Alves Redol publica um ano antes um estudo de caráter etnográfico chamado Glória: uma aldeia do Ribatejo. Mas, segundo a maioria dos críticos literários, Gaibéus configurase como a primeira "incursão" de Redol na arte neorrealista.
} 
o leitor a olhar para a classe abastada da sociedade já em seu título. Há ainda Alcateia (1944), o qual se distancia dos outros três por basear-se na história da quadrilha de ladrões de aldeolas dessa região. Será, então, que podemos considerar Oliveira um autor incompreendido ou que realmente engendrou um desvio do pensamento neorrealista?

A resposta dessa questão, naturalmente, percorre os diversos trabalhos que se dedicam à análise da escrita desse autor. Neste capítulo, vamos buscar compreender de que maneira a temática político-social se configura na prosa ficcional de Carlos de Oliveira para entendermos melhor como esse assunto se molda na sua obra artística. Com esse objetivo, propomos uma análise de dois dos romances pertencentes à "tetralogia": Casa na Duna e Pequenos Burgueses.

A escolha dos romances ocorre pelas seguintes razões: apesar de já ter sido muito trabalhado pela crítica, Casa na Duna possibilitou-nos uma reflexão aprofundada sobre o modo complexo como se tecem as relações sociais no ambiente gandarês, o que nos permitiu uma análise de temas como a exploração dos menos favorecidos e a desigualdade social no contexto rural português. Pequenos Burgueses, por sua vez, foi escolhido dada a maneira complexa como o autor apresenta as classes socioeconômicas de tal cenário, possibilitando-nos um estudo mais amplo sobre a temática das relações de classe na obra oliveiriana. Optamos por não escolher Uma Abelha na Chuva pelo fato de a obra abordar majoritariamente o conflito entre as classes favorecidas, os aristocratas em declínio por um lado e os burgueses em ascensão por outro, o que nos levaria a uma visão menos abrangente das relações sociais envolvendo os grupos mais pobres da Gândara. Alcateia também não foi escolhido por um motivo semelhante, pois fundamenta-se principalmente em um determinado setor social, reduzindo a visão mais geral do amplo e complexificado quadro social dessa região.

\subsection{Casa na Duna e Pequenos Burgueses}

Em um ensaio chamado "A Condição da Arte", Carlos de Oliveira diz que o objeto artístico deve ser observado como "raiz da solidariedade" (1945, p. 02), sendo destinado à compreensão do homem comum "tanto como à nossa própria" (Ibid.). Essas palavras ecoam a perspectiva de um jovem escritor que, desde cedo, vincula-se a causas partidárias, e tal visão, certamente, não passa incólume à sua obra. Já no início da sua vida artística, liga-se ao movimento do Neorrealismo, defendendo, pois, uma relação consubstancial entre o artista e o homem político. 
Ao trazer o termo "solidariedade" para a caracterização da arte, Oliveira exprime a concepção de que a obra deve ser parte de um compromisso afirmado por uma pessoa - o artista - em nome das necessidades de outros indivíduos. Não seria, entretanto, a manifestação de um sentimento de comiseração, muito menos um pedido de ajuda. $\mathrm{O}$ artista, de acordo com essa perspectiva, estaria imbuído do desejo de transformação social decorrente de injustiças que atingem as camadas mais desfavorecidas. Logo, seu trabalho seria, ao mesmo tempo, o de porta-voz desse anseio, o de suscitador da reflexão como um instrumento de denúncia e combate.

Tendo em mente tal ideia, pode parecer minimamente estranho que Casa na Duna, o primeiro romance de Carlos de Oliveira, vá centrar-se exatamente na trajetória de uma família pertencente à elite rural gandaresa. Porém, como observa Alexandre Torres, é surpreendente o fato de que esse seja um dos livros "onde mais perfeitamente se manifesta uma profunda compreensão do Neorrealismo" (1967, p. 256). Esse aspecto se observa justamente pelo fato de o autor trazer como foco do enredo a derrocada da família dos Paulos. A história desenvolve-se a partir do processo de mudanças socioeconômicas que ocorrem em Corrocovo, aldeia onde se encontra a quinta de Mariano Paulo, o que nos coloca, como leitores, diante de um panorama de transformações mais amplo dessa sociedade. É a partir de um quadro complexo de modificações que Oliveira traz ao seu primeiro romance uma análise sobre as relações de classe na zona gandaresa.

Mariano Paulo é dono de um amplo terreno, herdado de gerações anteriores, onde se desenvolve o plantio de milho e uva e a produção de vinho. Seus antepassados conseguiram, ao longo dos anos, ampliar a fazenda, em procedimentos que não ficam muito claros na narrativa. O que sabemos é que os Paulos, "um após o outro, tinham conseguido alargar a quinta, leira ${ }^{62}$ sobre leira, num tempo em que os camponeses trocavam a terra a canecas de vinho"63 (OLIVEIRA, 2004a, p. 11). Assim, as terras se expandiam, o domínio e o poder da família também. A família, assim, consolida-se ano após ano, sendo a principal fornecedora desses produtos na aldeia.

No início do romance, deparamo-nos com o jovem Mariano Paulo a caçar patos com seus amigos nas lagoas de Corrocovo. Nesse período, a quinta é ainda controlada por seu pai, o velho Paulo. Mariano casa-se com D. Conceição, que logo engravida. Entre

\footnotetext{
62 De acordo com o Dicionário Eletrônico Houaiss, "leira" refere-se a "sulco ou rego aberto na terra para que nele se deposite semente ou muda" e é um termo muito utilizado nos romances de Carlos de Oliveira ambientados na Gândara.

${ }^{63}$ Vamos utilizar como objeto central de estudo a sétima edição de Casa na Duna, texto publicado em 1980 pela Livraria Sá da Costa Editora. Nosso exemplar foi publicado pela Editora Assírio e Alvim em 2004.
} 
os capítulos IV e V, passam-se alguns anos, e o narrador em $3^{\mathrm{a}}$ pessoa começa a inserir importantes mudanças na paisagem de Corrocovo trazida pelo desenvolvimento capitalista e pela nova infraestrutura. Mariano acaba por assumir o lugar do pai, que aos poucos enlouquece. Hilário, seu neto, estudava em um colégio interno na cidade, mas passa a ser educado na quinta, para ficar mais perto de seu pai. O quinto capítulo já nos apresenta um ambiente que cheira "a óleo, a carvão queimado", simbolizado pela "gare" de trens. É um momento indicativo das mudanças socioeconômicas que passam a afetar a aldeia, atingindo consequentemente a família dos Paulos.

Tais transformações referem-se à chegada do capitalismo industrial a Portugal, que promove a mecanização do trabalho. Esse processo abrange também a área rural, onde máquinas passam a fazer atividades de forma muito mais produtiva e rápida que os camponeses, otimizando e ampliando a produção. Naturalmente, a mecanização gera mudanças na oferta de produtos da aldeia, o que é beneficiado pelos meios de transporte que também são otimizados. Assim, a estrutura socioeconômica da região modifica-se profundamente, e Mariano Paulo precisa lidar com um novo contexto que se forma.

Em contraste com o avanço do capitalismo na zona rural, está o posicionamento dessa personagem, totalmente contrário à mecanização da plantação. Com o aumento da oferta de produtos e preços mais baixos, a quinta passa a enfrentar problemas financeiros, pois já não consegue competir com tal situação dados os meios manuais de produção em sua propriedade. No capítulo IX, observamos o modo manual como dinâmica predominante no local:

O trabalho da quinta era feito com enxadas, a uva esmagada sem prensas, o milho escarolado à mão. A aguardente de Corrocovo corria ainda do tosco alambique como nos tempos do velho Paulo. A compra da grande máquina destiladora fora sempre adiada. Os homens continuariam a calcar os cachos, o bagaço, a escarolar as espigas (OLIVEIRA, 2004a, p. 35).

Aos olhos do proprietário, caso houvesse a mecanização, as estruturas socioeconômicas se alterariam de forma brusca:

Na quinta, tudo nascia da sua paciência. Se aparecessem as prensas, a destiladora, os escaroladores mecânicos, os homens seriam despedidos. Uma máquina faz o trabalho de cem braços. A oferta de mão de obra aumentaria em Corrocovo, as levas dos emigrantes e dos ganhões engrossariam e o povo das terras areentas debandaria em massa (OLIVEIRA, 2004a, p. 35). 
Não era essa a intenção de Mariano segundo o narrador. Assim, "a quinta continuaria silenciosa, sem o barulho dos motores. Os homens continuariam a semear e a colher, como há mil anos" (Ibid.).

Tal oposição ao processo revela o modo como as estruturas econômicas e de poder se constituíram historicamente em Corrocovo. Conforme as gerações vinham, a família central angariava novos terrenos e, consequentemente, mais poder. Os Paulos se fortaleciam, dando condições de sobrevivência àqueles que eram subalternos a eles. Mariano Paulo temia justamente promover mudanças nesse quadro. No entanto, as transformações ocorrem, e o leitor depara-se com uma condição de declínio econômico da propriedade, pois a exploração da terra do modo como é praticada no local já não pode enfrentar as mudanças na agricultura do processo capitalista de mecanização e o crescimento da região diante de novas estradas e meios de transporte de produtos. Nesse contexto, Carlos de Oliveira apresenta o modo como as relações sociais são tecidas na região, permitindo-nos pensar de que maneira elas se estruturam, como veremos adiante.

A estrutura de Casa na Duna segue o relato de um narrador onisciente, porém, entre a primeira e as seguintes edições, observa-se uma mudança nessa narração. Inicialmente, o narrador se apresentava explicitamente como aquele fazia as denúncias das condições de desigualdade social e exploração presentes em Corrocovo, indicando de forma clara e objetiva esses aspectos ao leitor. Era, assim, um narrador de caráter mais “dogmático”, como indica Maria Aparecida Santilli (1979, p. 162), pois ele buscava uma “clareza necessária” (DUARTE, 1998, p. 91) à mensagem que pretendia comunicar no papel de um autor neorrealista. Após as constantes revisões de Carlos de Oliveira, observamos já na sétima edição, chamada pelas editoras de "texto definitivo", uma presença menos preponderante de tal narrador no sentido de emitir opiniões críticas sobre o contexto gandarês. Há, sim, a função bem definida deste, isto é, o leitor é conduzido pelo desenvolvimento do enredo por ele, apresentando-nos também a descrição do ambiente e o aprofundamento psicológico das personagens. Porém, a voz mais crítica é colocada na narrativa através de uma personagem, o Dr. Seabra, além do uso mais constante do discurso indireto livre, que permite acesso à reflexão das próprias personagens. Tais mudanças permitem um papel mais ativo do leitor em formar sua própria reflexão sobre o cenário criticado, configurando uma mudança marcante do romance neorrealista segundo Lélia Duarte (1998, p. 94).

Assim, não podemos afirmar que há um narrador dogmático após a primeira edição do romance. De fato, ele é o responsável por construir o fio condutor do enredo - 
a trajetória de insucessos de Mariano Paulo - a partir da apresentação de fatos, de personagens e do cenário que aparecem sempre em relação uns com os outros. Conforme observa Alexandre Pinheiro Torres,

O autor da Casa na Duna jamais se refere aos factos, às coisas, às personagens, aos acontecimentos sem estabelecer as respectivas relações mútuas e, mais do que isso, sem lhes estabelecer as ligações visíveis ou invisíveis com um processo mais geral que os transcende (1967, p. 254).

Os elementos oferecidos pelo narrador - dentro da sua onisciência - revelam-se imbricados, sem que ocorram aspectos marginais que não completem a narrativa de algum modo. Esse mecanismo teria levado Oliveira a ser "o primeiro entre os neorrealistas a aperceber-se da necessidade de nunca ultrapassar o plano da referência às coisas, acontecimentos e personagens enquanto relação", segundo Torres.

Tal romance, desse modo, constrói-se progressivamente à medida que o narrador apresenta os elementos em relação, buscando criar a totalidade da ação "dialeticamente, isto é, sentindo os factos em função do seu significado real de causa e efeito, de acção e reacção, por meio dos contrastes e consequente dramatização", segundo analisa Armando Ventura Ferreira (1946, p. 36). O narrador oferece elementos de modo dinâmico, sem trazer ao leitor interpretações facilitadas. É por meio dessa construção dinâmica que se torna possível ao leitor ter sua própria interpretação. Gonçalo Duarte observa que, na primeira edição do romance, há a presença de um "narrador extradiegético que apela no sentido de uma mudança social necessária” (2008, p. 58). Na edição revista, tal apelo é excluído, e o leitor é quem chega a essa conclusão a partir da própria ação das personagens. Neste trabalho, como observamos, trabalharemos com as edições revistas.

A narrativa de 29 capítulos relativamente conectados é centrada no núcleo dos Paulos, porém há a inserção de pequenas histórias que completam o contexto geral elaborado, a exemplo da trajetória da empregada Palmira, que deixa a casa grande para se tornar uma microproprietária de terra ao lado do marido e das lembranças da personagem Lobisomem, um ex-trabalhador da quinta que não se encontra mais em atividade desde um grave acidente que sofreu, perdendo os movimentos da perna esquerda. Ainda assim, essas pequenas narrativas formam o complexo quadro de relações sociais entre proprietário rural e camponeses na Gândara, e a sua articulação permite que Carlos de Oliveira proponha sua reflexão sobre as relações de poder e de exploração que marcam essa paisagem. 
Um quadro próximo de Corrocovo parece também envolver a narrativa de Pequenos Burgueses, romance de 1948, que se passa na região de Fonterrada, um local perto de São Caetano e Corgos, duas vilas que já aparecem no primeiro romance. Temos novamente uma quinta como cenário, pertencente ao Major, entretanto não há exatamente um núcleo narrativo que delineia o romance em sua totalidade. Com uma estrutura interna bem distinta daquela vista em Casa na Duna, Pequenos Burgueses demonstra também a transformação do romance neorrealista observada por Duarte, pois rompe totalmente com a univocidade e o monologismo comuns ao movimento ao trazer um romance dividido em micro-histórias contadas por diversas vozes. Essa característica torna difícil a tarefa de se resumir o enredo do livro, justamente porque é composto por diversos pequenos enredos que se articulam, assim como as relações sociais observadas por Oliveira.

Lélia Duarte observa que a voz única e monológica presente na escrita neorrealista, considerando um viés mais ortodoxo, davam ao escritor uma espécie de função didática por meio da qual elucidaria o leitor sobre as desigualdades sociais que afligem a sociedade (1998, p. 91). Porém, “com a evolução do movimento, a univocidade desse discurso tende a complicar-se. Se os problemas continuam a ser vistos com relativa clareza, as soluções começam a ficar menos definidas e a voz narrativa não é mais tão senhora da verdade” (Ibid., p. 93). Assim, as denúncias passam a ser feitas de modo menos direto, “[...] muito mais confiante na capacidade do leitor" (Ibid.).

De fato, o caráter unívoco de um narrador que orienta a leitura expondo denúncias de problemas sociais não é algo presente em Pequenos Burgueses. A estrutura do romance é organizada a partir da presença de diversas vozes, alternando-se entre a voz das personagens ( $1^{\mathrm{a}}$ pessoa) e a voz de um narrador na estrutura do discurso indireto livre. Desse modo, o leitor permanece diante de capítulos dialógicos, nos quais personagens, narrador e o próprio leitor - segundo sua interpretação e sua organização - constroem as noções de crítica em torno do grupo social retratado. O autor " [...] deixa de colocar-se assim como dono da verdade, reconhecendo o receptor como companheiro na construção do sentido do texto" (DUARTE, 1998, p. 98). Tal estruturação polifônica intensifica-se pela composição em micronarrativas, o que confere aos capítulos uma maior autonomia em relação à ideia de continuidade da ação. Opondo-se ao narrador dogmático, Carlos de Oliveira conta com o leitor para construir a progressão do enredo a partir do que é relatado nas micro-histórias, tecendo, por meio do diálogo entre elas, uma rede representativa das relações sociais entre a elite gandaresa e os trabalhadores menos favorecidos. 
O romance inicia-se com uma breve descrição do verão e, em seguida, é-nos apresentada a personagem Raimundo, que pode ser considerada uma espécie de personagem central, pois, apesar de a trama ser composta por diferentes personagens, a presença dele é marcante e constante no decorrer dos capítulos. Raimundo não faz parte dos "pequenos burgueses", ele é alguém simples, da classe dos menos favorecidos. Fisicamente, é marcado pela sua lentidão ao andar, uma vez que sua perna esquerda é manca. Tal característica retoma a personagem Lobisomem, de A Casa da Duna em sua condição de coxo.

Justamente por sua dificuldade de locomoção, Raimundo tem uma ideia fixa: ter uma mula ou égua que possa levá-lo por onde deseja e precisa andar. Esse desejo é tão pulsante que, ao cochilar à tarde durante uma travessia entre a região de Fonterrada e a vila de Corgos, ele se põe a sonhar com a tal égua. Porém, quem possui uma égua forte e muito bonita é o Major, cuja presença é inserida de forma mais profunda no quarto capítulo. Raimundo escuta o cavalgar da égua do Major e admira-o, nutrindo seu forte objetivo de ter uma alimária, ainda que fosse um animal velho. Ele nos diz, através de seus pensamentos, que a mula não é, de fato, um sonho, mas, sim uma necessidade, dada sua situação claudicante.

Talvez pela relação que essa personagem tenha com as montarias, ele acaba por apresentar ao leitor, por meio de seu pensamento, mais duas figuras importantes também ligadas aos cavalos: Mestre Horácio, exímio ferrador desses animais, e D. Álvaro, negociante de venda e compra dos equídeos. Raimundo sempre conversa com Mestre Horácio, considerado o melhor da região em sua atividade. O comerciante, por sua vez, aparece no pensamento do homem coxo como um "cigano de cavalos", justamente pelo fato de praticar qualquer negócio para vender seus animais.

Raimundo vive em um casebre com sua filha, Maria da Luz, empregada na casa do Major. Sua profissão é decifrar pegadas nos chãos e ler a sina das pessoas, por isso ele se desloca de feira em feira na região. É um ótimo leitor de rastros, consegue identificar as pegadas deixadas no barro e na areia, sabendo se elas se referem a um animal ou a um homem. Logo no primeiro capítulo, a voz do narrador mistura-se à de Raimundo, e a estratégia do discurso indireto livre propaga-se a todas as personagens no desenvolvimento do romance. Assim, o leitor recebe informações de um narrador e também tem acesso ao pensamento das personagens feitos em $1^{\mathrm{a}}$ pessoa, em um intenso ritmo de oscilação entre uma voz e outra. 
Esse modelo narrativo proposto por Carlos de Oliveira ocorre a partir da $3^{\mathrm{a}}$ edição de Pequenos Burgueses, como constata a crítica Maria Aparecida Santilli (1979, p. 161), tornando a voz do narrador apenas uma a mais na tessitura do discurso. Desse modo, o leitor tem acesso a diferentes pontos de vista, diferentes consciências, sendo que cada uma apresenta uma determinada percepção do mundo. Observamos que o narrador mostra-se em trechos de descrição, porém, no aprofundamento psicológico das personagens, o discurso indireto livre é utilizado de forma mais intensa. Sob essa perspectiva, o dogmatismo observado por Santilli se esvanece, pois não há um narrador portador da certeza, impondo - ainda que implicitamente - um julgamento sobre as personagens. O que ocorre nesses dois romances difere-se dessa função mais "didatizante" de narrar, algo que se observa mais preponderantemente nos romances neorrealistas de tendência mais ortodoxa, segundo análise de Lélia Duarte (1998, p. 98).

No romance, a fusão entre a voz do narrador às das personagens aproxima o leitor de cada uma delas. Cada figura apresenta-se por meio de suas falas e de seus pensamentos, e aquele que lê torna-se ativo na função de conduzir o percurso narrativo e articular as diferentes mundividências e reflexões. As vozes que se fundem exigem uma leitura atenta e revelam uma preocupação com a forma do romance que pode ser lida como um desvio das pretensões ortodoxas do Neorrealismo. A ideia fixa de Raimundo por uma mula, por exemplo, é-nos elucidada a partir de um parágrafo que demonstra eficazmente esse recurso:

Quando lhe surge um rasto de ferradura, firme, aliciador, baixa-se a custo e fita, sem memória, sem gestos, o torneado da pata, o desenho dos cravos, a curva regular e doce do casco. É que precisa de uma mula. Mesmo lázara, mesmo ruça, um trambolho que seja, desde que tenha quatro pernas de comprimento igual, senão coxeia como eu, e a força para me carregar de povoado a povoado. A peregrinação diária custa muito e o remédio, já se vê, era a mula. O que não sei ao certo é se vale esperar ainda por ela, depois de tantos anos. O sonho tornou-se um calo na sua alma, às vezes o desalento arranca-lho, arranca sim senhor, mas o maldito volta a nascer, e é sempre a mesma comichão agradável que dá gosto coçar ao de leve, quantas vezes fui enganado?, tantas que nem me recordo, e abana duvidosamente a cabeça (OLIVEIRA, 2005, p. 08).

No trecho, observamos o uso do pronome "lhe", no início, indicando a fala do narrador em referência a uma terceira pessoa, no caso, Raimundo, além do uso de verbos na $3^{a}$ pessoa do singular - "baixa-se / precisa". Sem uma mudança de pontuação notável, a fala em $1^{\text {a }}$ pessoa de Raimundo já aparece: "Mesmo lázara, mesmo ruça, um trambolho que seja, $[\ldots]$ senão coxeia como eu $[\ldots]$ ”. O período seguinte mostra a fusão: tanto o 
narrador como Raimundo poderiam ter dito: "A peregrinação diária custa muito e o remédio, já se vê, era a mula”. O uso do Pretérito Imperfeito do Indicativo, por um lado, pode explicitar a fala do narrador, que ao falar em discurso indireto utiliza tal tempo verbal. Por outro lado, o uso desse tempo também pode indicar a fala de Raimundo, pois, na fala corrente de Portugal, ele é utilizado também com valor hipotético ou condicional: seria a mula o remédio. O parágrafo continua com a oscilação constante entre vozes, que constroem dialogicamente o desejo desta por uma montaria, sendo intensificado no último período: o narrador cita que o sonho se tornou um calo na alma de Raimundo, dizendo que o desalento "arranca-1ho". Mas a oração seguinte: "arranca sim senhor" insere a voz da personagem, levando a última sentença à fusão total com o narrador: "quantas vezes fui enganado?". Afinal, o leitor se questiona: é o homem coxo ou aquele que narra que se sente enganado?

O discurso indireto livre é um dos principais mecanismos de Pequenos Burgueses, o que confere à narrativa um ritmo acelerado e demonstra a grandeza do autor no seu trabalho com a linguagem. Conforme analisa Santilli (1979, p. 161) à luz de Mikhail Bakhtin, essa ruptura do romance monológico permite que as personagens deixem de ser objetos do discurso e tornem-se sujeitos do próprio discurso. A autora define como um "achado estético" (1979, p. 163) a narrativa flutuante desse romance, indicando que a voz do narrador se dá pela exclusão das outras vozes, o que a distancia da perspectiva dogmática citada por Lélia Duarte em relação aos romances neorrealistas mais ortodoxos. Já Eduarda Dionísio (1970, p. 271-274) afirma que a reformulação de Oliveira levou a um apagamento das explicações fornecidas pelo narrador horizontalmente, criando uma situação de silenciamento, como observa Gonçalo Duarte (2008, p. 99). Esse silêncio recai de certa forma no narrador e sua voz abre espaço para a fala das próprias personagens. Assim, dialogicamente, a ação elaborada configura-se a partir de uma teia de pensamentos distintos, estabelecendo um paralelo entre a forma e o conteúdo abordado: as vozes tecem a narrativa que explora justamente a teia de relações sociais gandaresas. A estrutura e o enredo tecem-se concomitantemente na leitura ativa e atenta.

Um aspecto que nos chama atenção relativamente à dinâmica narrativa de ambos os romances é a descrição do ambiente no qual as personagens estão inseridas. Em Casa na Duna, há a predominância de capítulos iniciados por breves descrições, que inserem o leitor no cenário da Gândara, a exemplo do capítulo IV: 
A chuva, em grossas bátegas, derreava o telhado. Firmino consertava os rombos por onde o inverno entrava, mas a água e o vento tornavam a abri-los, ainda maiores.

A lagoa crescera um metro sobre o bunho e invadia, às golfadas, os casebres de Corrocovo. Corrocovo era isto: tocas sem lume, devassadas pelo temporal; crianças quase mortas de frio; os campos alagados; o céu tão baixo que parecia poisar na rama dos pinheiros; chuva insistente, dia e noite (OLIVEIRA, 2004a, p. 19).

Ao relatar a ação do inverno na quinta dos Paulos, o narrador indica uma progressão temporal. Observamos, no desenvolvimento do romance, que outras estações recaem sobre o local, sugerindo certa passagem do tempo. Assim, acompanhamos o drama de Corrocovo desde o estio que seca as lagoas das aldeolas até o rigoroso inverno marcado pelas chuvas, dentro da passagem dos anos. A descrição da natureza favorece a análise crítica da condição de vida dos camponeses, como veremos adiante.

Em Pequenos Burgueses, observamos também a presença constante da descrição dos ambientes. Já o aspecto descritivo sobre as personagens ocorre de forma menos preponderante, justamente pelo fato de o recurso do discurso direto livre permitir que as próprias personagens "descrevam-se" por meio de seus pensamentos e atitudes. Entretanto, a descrição torna-se um aspecto central de ambos os romances. Ao falar sobre a paisagem e as situações em que as pessoas estão inseridas, Carlos de Oliveira não nos oferece uma simples imagem de onde se passa a trama. Na realidade, a descrição estrutura-se como um fator essencialmente ativo ao enredo, pois indica que o ambiente e o contexto histórico impõem determinadas condições de vivência às personagens. Assim, o romance elabora-se tanto pela ação dos indivíduos como pela influência do cenário sobre eles, de forma dialética, a fim de compor o mundo social da Gândara portuguesa. Logo, a descrição e a narrativa combinam-se de forma ativa no desenvolvimento de olhar social crítico que Oliveira objetiva em ambos os romances, como abordaremos a seguir.

\section{2. "De verão e de inverno - casa sem telha" ${ }^{64}$ : a relação entre as classes sociais e a exploração em Casa na Duna e Pequenos Burgueses}

O subtítulo acima é parte do verso que abre o poema IX da primeira edição de Turismo (1942) e narra as condições de vida dos habitantes das aldeolas gandaresas por meio da figura do "ganhão" - um tipo de trabalhador da zona rural que se desloca,

\footnotetext{
64 Verso extraído do poema IX da primeira edição de Turismo, de Carlos de Oliveira. In: TORRES, A.,
} 1989 , p. 350. 
geralmente, para lugares onde há serviços temporários. Tal verso condensa algumas ideias centrais que são recorrentes também na prosa oliveiriana: a progressão temporal, dada pela referência às estações do ano, a ação do meio ambiente sobre os indivíduos e a miséria em que vivem, concretizada pela ausência de telha em uma casa. Esses elementos são peças centrais na construção do mundo social que Carlos de Oliveira busca mostrar em sua obra, mais especificamente nos romances que compõem a "Tetralogia da Gândara".

O modo como o autor insere as relações sociais em sua prosa coloca-o, como observamos anteriormente, em um lugar distinto no movimento neorrealista, sendo considerado um escritor incompreendido, nas palavras de Alexandre Pinheiro Torres (1967, p. 249). Mário Dionísio, em seu prefácio à terceira edição do livro Casa na Duna, diz-nos que "a personalidade de visão e de processos de Carlos de Oliveira se revelou desde logo inconfundível" (In: OLIVEIRA, 1964, p. 11), e seu caso bastaria "para desmentir a tal uniformização" (Ibid.) que muitos críticos quiseram forçar ao Neorrealismo. Essa singularidade exaltada por Dionísio em seu texto é justamente observada já no primeiro romance de Oliveira a partir do quadro social que busca elaborar e da maneira como constrói sua própria leitura da sociedade de que fala.

Um dos aspectos principais dessa diferenciação do escritor diante de seus companheiros de grupo ocorre, como vimos, pela sua opção de trazer, na prosa, a perspectiva burguesa como mote de três dos seus primeiros livros (não se encaixa Alcateia, de 1944, nesse grupo pois o seu foco é uma quadrilha de ladrões gandareses). Não buscamos, neste trabalho, analisar a questão da heterodoxia da qual muitos críticos acusam Oliveira por ser um dos primeiros a "violar o espaço burguês"65, como afirma Torres (1967, p. 252, grifo do autor), mas vamos partir desse dado para analisar o olhar sócio-histórico que ele desenvolveu em sua prosa ao abordar as relações entre as diferentes classes sociais que habitam o espaço rural da Gândara.

Casa na Duna e Pequenos Burgueses trazem, cada qual à sua maneira, narrativas baseadas na interação de diferentes camadas socioeconômicas de um local determinado. Mariano Paulo, no primeiro romance, é a figura centralizadora de um quadro de transformações de classes e de estruturas provocadas pelo movimento do capitalismo em Portugal provavelmente no início do século XX, afinal não há indícios explícitos do período em que se passa a trama. Porém, a narrativa e a descrição do ambiente falam a

\footnotetext{
65 Destaque feito pelo autor.
} 
todo momento do processo de expansão industrial e infraestrutural que chega à zona rural. Conforme observa Dionísio em seu prefácio, tudo indica que o cenário dessa obra é "um mundo de realidade enganosamente suspensa no tempo, anterior à revolução industrial dois séculos depois dela e onde, no entanto, ela pesa e irresistivelmente penetra dos modos mais inesperados e dramáticos" (In: OLIVEIRA, 1964, p. 23). Ora, tal quadro aponta para um período de atraso econômico confrontado pela chegada da inovação capitalista - já não recente em outras nações - à zona rural portuguesa, com força transformadora feroz.

Conforme analisa Jaime Reis, "é geralmente reconhecido que nas décadas que precederam a Primeira Guerra Mundial se assistiu a um crescimento industrial e a transformações sem precedentes nas economias mais atrasadas da periferia europeia" (1987, p. 207), e, de acordo com uma quantidade reduzida de estudos, “[...] tudo indica que Portugal não foi uma exceção a estas tendências” (Ibid.). Segundo sua pesquisa,

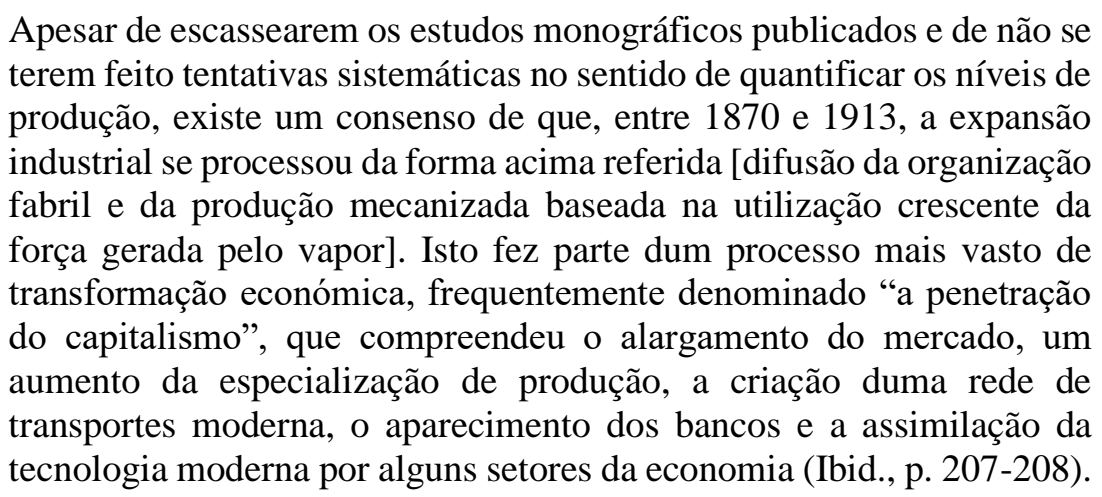

A título de ilustração, entre 1850 e 1910, foram construídos cerca de 15 mil quilômetros de estradas e 2900 quilômetros de linhas de ferro em Portugal, apontando o expressivo desenvolvimento de obras públicas no período diante da intensificação do processo industrial (MARTINS, 1997, p. 490-491).

Em oposição a esse setor, a agricultura sofre diversas crises desde a segunda metade do século XIX e "A partir da viragem do século verificou-se uma desaceleração do crescimento da produção cerealífera, e a viticultura atravessou uma crise de sobreprodução e falta de mercados", de acordo com Martins (Ibid., p. 495), considerando que a produção de vinho favoreceu-se das técnicas mecanizadas. Tal quadro de mudanças introduzidas pelo avanço capitalista aparece em Casa na Duna de modo devastador: as transformações econômicas levam à derrocada da quinta dos Paulos - um reflexo do que ocorria no setor agrícola português. E tais modificações têm como consequência a transformação das classes que interagem nesse contexto. 
Desde o início dessa narrativa, o leitor acompanha o progresso da propriedade dos Paulos e o modo como as relações sociais se estabelecem em tal cenário. Temos contato com a formação da quinta, a qual se expande, em seu passado, a partir da situação vulnerável de camponeses, que "trocavam a terra a canecas de vinho" (OLIVEIRA, 2004a, p. 11). Nos capítulos iniciais, quando a casa e a propriedade são descritas, também são apresentadas as personagens de Mariano Paulo, seu pai, Firmino e Lobisomem, além dos amigos de juventude do então jovem Paulo.

Ao mesmo tempo em que se constrói a imagem da elite dominante em Corrocovo, também se elabora a figura das personagens a ela submetidas, como o empregado Lobisomem. Nos tempos do velho Paulo, ele era "moiro da quinta" (OLIVEIRA, 2004a, p. 09), isto é, um trabalhador dedicado à propriedade. Pela sua força excepcional, o dono da quinta sempre o elogiava, chamando-o de "toiro". Na linguagem popular, podemos dizer que Lobisomem era o "faz-tudo" do local: "Alto e escuro como um tronco da Gândara, pegava na enxada, no machado, carregava o milho das tulhas para a quinta, em grandes sacos, para as carroças que esperavam no portão" (Ibid.).

A nomenclatura de "moiro da quinta" também nos permite pensar em um segundo aspecto possivelmente ligado a Lobisomem. "Mouro" é o adjetivo utilizado na Península Ibérica para se fazer referência aos indivíduos árabes e berberes islamizados advindos do Norte da África que, entre os anos 700 e 1492, aproximadamente, dominaram a região (MATTOSO, 2000). O termo vem do latim mauri, que significa "negro", uma característica relativa à cor da pele mais escura desse grupo, sendo originária do termo "mauritanos", aqueles que vêm da Mauritânia. Nesse sentido, "mouro" relaciona-se à ideia de pessoa estrangeira. Sendo assim, podemos considerar a hipótese de que Lobisomem seja um imigrante, alguém que veio de fora de Corrocovo para buscar trabalho.

Não há exatamente essa referência no romance, mas a alcunha de "moiro" nos permite tal interpretação. É interessante, porém, pensarmos que o uso dessa palavra condensa na personagem seu aspecto físico - era alto e escuro "como um tronco da Gândara" (Ibid.) - e sua função de trabalhador devotado, que atua sem descanso. Ora, ao criar a fusão entre esses dois elementos, Carlos de Oliveira reforça que Lobisomem era reconhecido somente como força de trabalho. Seu valor equivale ao seu vigor físico de ser carregador e ajudante geral da quinta dos Paulos. Sua imagem de "homem" não era vista além de sua função como "trabalhador", constituindo-se como uma "mercadoria viva", nas palavras de Marx em seus manuscritos: 
O trabalhador produz o capital, o capital produz o trabalhador. Assim, ele produz-se a si mesmo, e o homem enquanto trabalhador, enquanto mercadoria, constitui o produto de todo o processo. O homem não passa de simples trabalhador e, enquanto trabalhador, as suas qualidades humanas existem apenas para o capital, que lhe é estranho. (2017, p. 159)

Contudo, a situação desse empregado muda completamente. De "faz-tudo" ele se torna uma espécie de agregado da fazenda após um grave acidente na adega: "Caíra-lhe uma dorna por cima, quando calcava o mosto do velho Paulo" (Ibid., p. 10), fazendo-o perder os movimentos da perna esquerda. Sua atividade já não é mais possível e seu papel se transforma. O reconhecimento de outrora do patrão, que lhe dizia "Toiros, ao pé de ti, são ratos" (Ibid., p. 31), torna-se apenas uma lembrança durante sua lenta marcha arrastando sua perna morta. Lobisomem come e bebe à vontade na casa dos Paulos, possivelmente em uma espécie de consideração pelos serviços dedicados no passado.

A relação do empregado coxo com o velho Paulo e, depois do acidente, com Mariano mostra o modo como se configura o vínculo de trabalho na quinta de forma geral, algo que assume uma proximidade entre o patrão e o funcionário. A situação repete-se no capítulo VII, quando a empregada da casa, Palmira, avisa Mariano Paulo que vai deixar seu cargo para se casar. Ela se despede de Hilário, o filho do proprietário, lamentando que nunca mais vai vê-lo. Nesse momento, o dono da casa afirma: "Qual nunca mais o vê. Vai para o Brasil? Não vai. Nesta casa ninguém lhe fecha as portas. Apareça quando quiser" (OLIVEIRA, 2004a, p. 30). Esse comportamento de proximidade demonstrado nas ações do velho Paulo e seu filho permitem uma análise das relações de trabalho praticadas na quinta de Corrocovo e da sua organização.

Mesmo diante da falência de sua propriedade, Mariano Paulo é extremamente resistência à ideia de mudanças nas estruturas de produção do local. O trabalho era manual, desempenhado por homens que ganhavam a jorna - o pagamento pelo serviço diário. No pensamento dele e de seu amigo, Dr. Seabra, a adoção do trabalho mecanizado traria problemas à ordem da quinta:

Uma máquina faz o trabalho de cem braços. A oferta de mão de obra aumentaria em Corrocovo, as levas dos emigrantes e dos ganhões engrossariam e o povo das terras areentas debandariam em massa. Ao fim da caminhada, a gente da Gândara encontraria os esteiros do Tejo, os valados lodosos, as febres do arroz. Ou o chão alheio dum novo continente (OLIVEIRA, 2004a, p. 35).

O filho do velho Paulo não tinha intenção de promover tais transformações em suas terras, onde os homens continuariam a semear como faziam "há mil anos" (Ibid.). Para ele, a 
plantação deveria manter-se às antigas, pois era, por um lado, mais seguro para si mesmo - afinal o investimento em mecanização envolveria uma quantia de que não dispunha em princípio -, por outro lado, mais seguro para seus trabalhadores, que estavam ligados à terra, e uma mudança na organização de trabalho poderia levar à necessidade da emigração deles.

Mariano Paulo parece, ao longo da narrativa, preocupar-se com a condição de seus empregados, reconhecendo a dependência destes à sua terra. Em outra passagem, no capítulo XII, deparamo-nos com uma situação periclitante. A chegada do outono trouxe o fracasso das colheitas, causado pela ação do tempo: chuvas imprevistas, que estragaram as raízes e, posteriormente, a ação do forte calor, que queimara o resto. Nesse cenário, a fome se alastrava na aldeia. Dr. Seabra observa que os ganhões que foram trabalhar nos arrozais gastavam sua jorna comprando quinino, usado como medicamento. O médico afirma: "Partiram [os ganhões], passaram alguns meses no lodo, amealharam meia dúzia de moedas e voltaram. Pois cá têm à espera a mesma fome dos que não saíram" (OLIVEIRA, 2004a, p. 35). O salário recebido era gasto com remédios e a condição de fome se mantinha para os camponeses.

Tal contexto remete-nos ao verso do poema que abre esta seção, publicado na primeira edição do livro Turismo (In: TORRES, 1989, p. 350):

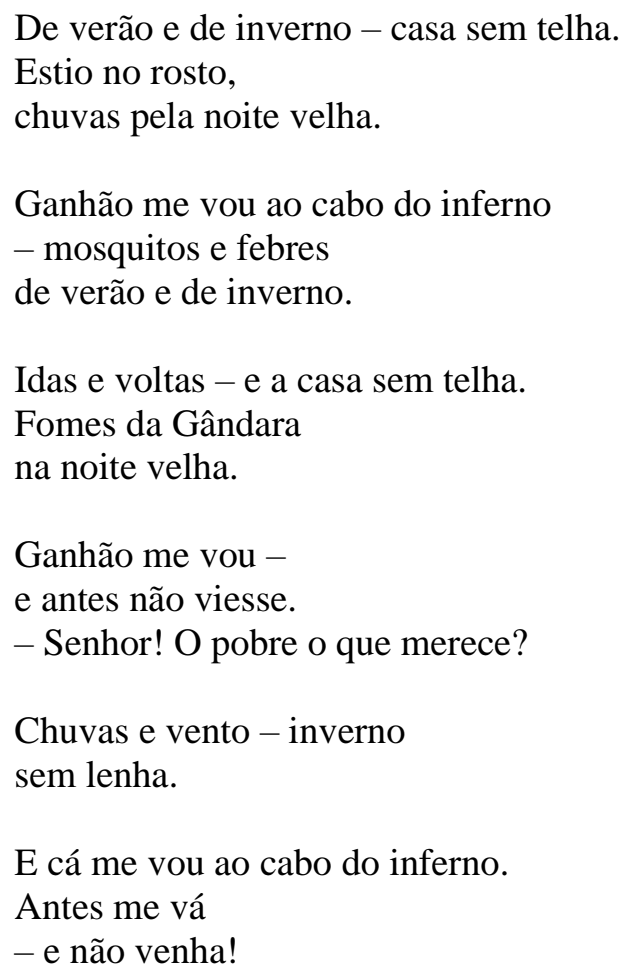


À mercê da força da natureza e do fracasso das colheitas, esses camponeses mantêm-se em condição de privação. Aqueles que partem em busca de trabalho fora da propriedade voltam e deparam-se com a mesma fome que deixaram.

A voz poética abre o poema indicando ambas as estações: seja no frio, seja no calor, a casa se mantém sem telha, isto é, sem proteção, pois desse material constroem-se as coberturas e tetos. Uma residência "sem telha" é, assim, um local desprotegido, onde se fica sujeito a quaisquer malefícios. Nos dois versos seguintes, observamos os problemas: "Estio no rosto / chuvas pela noite velha". De dia, o sol aflige a face e, de noite, na "noite velha", é a chuva que atinge aquele que mora em uma casa que não tem um teto para abrigo. O adjetivo "velha" ainda nos remete a uma situação temporal antiga, ou seja, que existe há tempos - "há mil anos".

$\mathrm{Na}$ estrofe seguinte, o sujeito poético aparece por meio da figura do ganhão, também chamado de "seareiro" ou “jornaleiro". Eles vão a locais que demandam mão de obra, porém em um regime de trabalho pouco assegurado: são funções pontuais, que podem surgir ou não, inserindo esse trabalhador em uma forma de subemprego. Os ganhões surgem, sobretudo, no contexto rural, pois acabam por desempenhar atividades ligadas à plantação e à colheita de produtos. Assim, em um país basicamente rural como era Portugal no início do século XX, a sua imagem representa a precariedade a que estavam condicionados muitos camponeses da região gandaresa, considerando que no período cerca de $61 \%$ da população ativa lusitana pertencia ao setor primário (MARTINS, 1997, p. 499).

A partir da colocação da voz poética em primeira pessoa: "Ganhão me vou ao cabo do inferno", é indicado o seu deslocamento para uma região de nome nada acolhedor, mas que possivelmente apresenta alguma forma de subsistência a esse trabalhador. Do mesmo modo que sua casa está destelhada, esse indivíduo também está sujeito a "mosquitos e febres", mais uma imagem que sugere o abandono desses homens.

O desamparo do trabalhador volta a ser acentuado na terceira estrofe. Novamente, temos uma referência temporal: "idas e voltas", que sugere o período em que o ganhão se desloca, trabalha, retorna à sua terra e assim sucessivamente, em um ciclo buscando a sobrevivência. Sua casa permanece sem telha, e a Gândara tem fome. A fome não é apenas de um indivíduo, mas possivelmente de todos os camponeses, dado o uso do termo no plural ("Fomes"). O plural desse termo também suscita a ideia de que a fome desse povo não é somente àquela gerada pela falta de alimento, e sim pela falta de condições dignas de sobrevivência, de medicamentos, de acesso à educação e à cultura. É uma fome 
de tudo que pode promover uma vivência decente. A voz poética nos fala de uma situação de precariedade total em que não há proteção, mas há fome e suscetibilidade a doenças, além da situação instável de trabalho temporário.

Nesse momento, observamos um ponto de aproximação da prosa e da poesia de Carlos de Oliveira, que traz o ganhão para ilustrar, de um lado, a conjuntura de privação do ambiente da Gândara e, de outro, uma situação de abandono ligada às estruturas trabalhistas na zona rural. $\mathrm{O}$ meio ambiente promove as intempéries que expõem os camponeses à precariedade. No entanto, o esforço e a remuneração pelo trabalho desses moradores tampouco lhe permitem fugir da falta de condições dignas de vivência. Os ganhões, citados pelo Dr. Seabra, trabalham, mas não recebem o suficiente para enfrentar a fome e as doenças que lhes esperam em Corrocovo. Assim ocorre no poema também: a voz poética que se coloca como ganhão fala sobre seu deslocamento dizendo "antes não viesse", em uma oposição entre os verbos "ir" e "vir", o que pode sugerir a ida e a volta do trabalhador, isto é, uma reflexão sobre seu retorno ao cenário precário em que vive.

No romance, Mariano Paulo demonstra preocupação com a questão, conforme nos comunica o narrador: "Julgava-se também com alguma responsabilidade na miséria de Corrocovo. Pagava jornas baixas, insuficientes, mas o certo é que não podia pagar mais" (OLIVEIRA, 2004a, p. 47). O dono da propriedade tem consciência da condição de seus empregados, é certo. Entretanto, o reconhecimento de sua responsabilidade é, pela voz do narrador, parcial: “julgava-se com alguma responsabilidade”. Essa nuance é intensificada no mesmo diálogo com a fala de Dr. Seabra ao amigo: "Uns tostões a mais ou a menos não resolveriam nada. Nem isso está nas suas mãos. Mas, de facto, aflige. [...]” (Ibid.). O médico completa sua fala: “[...] Crianças com barrigas enormes, os olhos purulentos, as pernas como espetos. [...]" (Ibid., p. 47-48), demonstrando o efeito da fome e de doenças nos meninos da aldeia.

Mariano Paulo, diante da reflexão dessa conversa, reconhece a situação precária dos habitantes de Corrocovo, mas entende que não é sua culpa a pobreza que se alastra. Ora, o raciocínio da personagem aponta em outra direção: "Via-se lutando também para manter a quinta, calculava os prejuízos daquele ano desastroso. As dificuldades batiam à porta de toda a gente. Iam longe os tempos em que a agricultura fazia fortunas" (Ibid., p. 48). O proprietário vê-se na posição de prejuízo, a atividade já não lhe rende mais o que rendera outrora, e isso o impede de pagar as jornas mais altas. A miséria do povoado é, assim, colocada pela personagem como uma consequência da mudança dos tempos no pensamento de Mariano Paulo, algo que também está impondo-lhe dificuldades. 
Assim, a culpa desse cenário não seria, evidentemente, sua, afinal ele é mais uma vítima desse novo tempo de escassez. Ademais, tal panorama mostra que a proximidade entre patrão e empregado citada acima é, na realidade, ambígua, pois, ainda que o dono da propriedade reconheça a ligação dos camponeses à terra do mesmo modo que também se liga a esta, ele não vislumbra modificar as estruturas econômicas do local, indicando seu anseio por manter o poder que tem sobre o contexto há gerações.

Essa passagem de Casa na Duna ilustra a visão de Carlos de Oliveira sobre o movimento de modificações socioeconômicas com a entrada do capitalismo industrial na zona rural gandaresa. As relações sociais construídas nesse cenário se formam por meio da terra e da sua importância como meio de produção. A organização do trabalho na propriedade dos Paulos segue um modelo arcaico, como o próprio narrador indica ao expor a resistência de Mariano diante da mecanização da lavoura. Ocorre que o esquema econômico local passa por mudanças intensas com o desenvolvimento capitalista. A produção da quinta já não tinha "fôlego" para competir com o milho e o vinho que "chegavam doutras regiões, de terrenos férteis onde a produção era menos dispendiosa" (OLIVEIRA, 2004a, p. 48).

Diante de um novo quadro que se configura, essa personagem - por meio da sua resistência à modernização dos meios de produção - representa um pensamento anterior que, de certa forma, tenta se manter vivo. Esse modo de pensar, porém, não se refere somente a aspectos econômicos como uma leitura breve poderia indicar. O filho do velho Paulo recusa as transformações que a entrada do capitalismo gera, pois ela é responsável por uma transformação das relações de poder dentro do microcosmo da quinta. Ele é representante de uma elite agrária que mantinha o controle socioeconômico dentro de um mercado interno reduzido, baseado justamente em técnicas agrícolas mais arcaicas. Pela narrativa, observamos que a família em questão enriquece e alarga sua propriedade a partir da relação com os camponeses desfavorecidos e Mariano reproduz esse pensamento. Mudar a maneira como se produz é, consequentemente, mudar a organização socioeconômica da propriedade, algo que ele vai refutar até onde for possível.

Mariano Paulo reproduz o raciocínio de uma parcela da classe dominante que, em um processo de mudanças, teme a alteração de seu status hegemônico. Essa expressão traz a noção básica, segundo os escritos de Marx e Engels ${ }^{66}$, de que, ao manter o controle econômico, um grupo controla todos os aspectos da vida social. O dono da quinta de

\footnotetext{
${ }^{66}$ Cf. Manifesto Comunista e o verbete "classe dominante" no Dicionário do Pensamento Marxista, p. 110. (Versão Digital)
} 
Corrocovo representa tal domínio, o que o leva a pensar na sua suposta culpa diante da miséria enfrentada pelos camponeses de seu território. Essa ideia é também verificada na progressão hereditária presente na narrativa, afinal a propriedade se desenvolve historicamente nas mãos da família desde Silvério Coxo, o ancestral que plantara uma nogueira "na primeira nesga de chão comprada pelos Paulos" (OLIVEIRA, 2004a, p. 36). Logo, a sucessão familiar conquista aos poucos o poder em Corrocovo, e Mariano tem a responsabilidade de mantê-lo.

No entanto, paralelamente à crise econômica enfrentada pela quinta, o dono do local vê-se obrigado a lidar com mais um entrave: o desinteresse de seu filho pelos negócios da propriedade, como observa o narrador do romance: “O desprendimento de Hilário por tudo aquilo desalentava Mariano Paulo. Dias e dias sem uma palavra, vagueando pela quinta ou fechado no quarto. Não era vida para um homem feito" (Ibid., p. 49). O jovem auxiliava o pai, mas sempre a contragosto, conforme conta o narrador: "No escritório, Hilário fazia de má vontade as folhas do pessoal, alinhando nomes e dinheiros, conferindo a caderneta de Firmino" (Ibid., 2004a, p. 36). Pensando em manter o domínio do local, Mariano cogitava ter um novo herdeiro com a empregada da casa: "Hilário não era o herdeiro que sonhara; a pesada herança dos Paulos exigia ombros fortes de alguém capaz de confundir a quinta com a vida; um filho de Maria dos Anjos; da terra, mais exactamente" (Ibid., p. 107).

Mariano Paulo, nesse âmbito, enfrentava duas situações que colocavam o futuro da sua propriedade em risco. Em um âmbito particular, seu filho demonstrava nenhum interesse em levar adiante a quinta e a sua produção, ameaçando o poder familiar geracional. Em âmbito mais amplo, o processo de desenvolvimento do capitalismo industrial que chegava a Portugal deixava em risco as estruturas arcaicas nas quais o poder econômico da família se assentava. A situação era periclitante e ele estava ciente, mas ainda conservava sua posição contraria à mecanização da fazenda: "Com máquinas não vou. Dá-se muita guita a esse papagaio e o vento, quase sempre, leva-o" (Ibid., p. 37).

As personagens que dialogam com o dono da quinta, os amigos Dr. Seabra e Guimarães, apresentam visões distintas. Este, desde o início, é a voz da mudança e aconselha Mariano Paulo a investir em maquinário: "Quarenta, cinquenta por cento das colheitas, vão-se-lhe embora. Ponha motores nos poços e rega a quinta em metade do tempo" (Ibid., p. 36). Seus conselhos ilustram o nascimento de um pensamento capitalista industrial: mecanização da produção, aumento da competitividade, diminuição do tempo empregado no processo agrícola. O amigo compreendia que o domínio dos Paulos já não 
poderia concorrer com a mercadoria que agora chegava de outras cidades graças aos meios de transporte implementados na região:

As novas estradas traziam às feiras de Corgos produtos de toda a parte. Pelas estradas, pelo caminho de ferro, nos vagões, nas camionetes, o comércio das cidades, das vilas, das aldeias, acelerava-se, levava daqui para ali, fazia permutas, entrechocava-se, explorava todos os mercados. O isolamento dos pequenos meios desaparecia (OLIVEIRA, 2004a, p. 48).

O aprimoramento da infraestrutura trazia forte concorrência à produção dos pequenos proprietários, tornando-se impossível competir em termos de preço com o aumento da oferta.

O pensamento mais capitalista de Guimarães ecoava na cabeça de Mariano Paulo, mas o amigo Dr. Seabra se mantinha contra a mecanização também. Essa personagem é essencial para a análise sobre o modo como Carlos de Oliveira explora a questão de classes no livro. Como observa Gonçalo Duarte, “a consciencialização social dá-se, então, em grande medida, através das posições de personagens inseridas nos próprios romances, geralmente pertencentes a classes superiores" (2008, p. 59). O médico torna-se uma figura chave para a construção de mundo social do autor, considerando-se que o narrador já não expõe opiniões sobre o assunto. A reflexão feita pelo leitor é possível por meio da visão de Seabra, o qual transita entre o mundo da classe dominante e o da classe dominada, uma vez que os aldeões são também seus pacientes. A precariedade e a miséria que atingem os camponeses o preocupam e ele as transmite a Mariano Paulo em seus diversos diálogos.

Ao longo da narrativa, Dr. Seabra conversa com o amigo sobre a questão da quinta e a criação de Hilário, aconselhando-o. Ele se posiciona contra a ideia de mecanizar o trabalho da propriedade justamente porque considera que, se houver uma má colheita, Mariano Paulo teria problemas em pagar empréstimos e a situação se tornaria pior. Concomitantemente à preocupação do amigo, Seabra indica sua inquietação diante da pobreza da aldeia. Em um primeiro momento, ele expressa sua visão sobre os doentes e famintos. Mas, no desenvolvimento do enredo, suas reflexões se tornam mais politizadas, como vimos no capítulo XVII:

Nos últimos tempos, o Dr. Seabra mostrava-se muito interessado por política:

- Tenho pensado que toda esta gerigonça social precisa de uma grande volta. Quanto mais não seja por uma questão de decoro elementar, de humanidade (OLIVEIRA, 2004a, p. 72). 
O amigo alertava-o que esses pensamentos faziam-lhe ser chamado em Corgos de comunista. Dr. Seabra nega sê-lo e diz não saber o que é o comunismo. Mas afirma: “Tenho um pouco de coração, que diabo, e não posso ver homens a viver como os bichos ou pior que bichos" (OLIVEIRA, 2004a, p. 73).

O médico - pertencente a elite gandaresa - nega uma visão marxista explícita, refutando ser comunista, dizendo desconhecer tal sistema socioeconômico. Contudo, a consciência da questão de classe por meio da exploração pelos dominantes sobre os menos favorecidos é trazida ao romance exatamente por essa personagem. Logo, por meio dele, o autor transita entre os grupos sociais abordados na obra e assim consegue expor sua visão sobre o assunto. No mesmo capítulo em que Mariano Paulo pede-lhe prudência ao tocar nesse assunto, o médico expressa-se:

- Pois bem, quero chegar a isto: esses homens [os camponeses] fazem as fortunas dos grandes lavradores ribatejanos e vêm acabar a Corrocovo sem um naco de broa, sem enxerga, sem a porcaria dumas drogas. Não falo já doutras aspirações, de alegria, de felicidade, de um destino digno. Falo das coisas primárias, inadiáveis: alimentação, cobertores, remédios (Ibid., p. 73).

Esse é o trecho do romance no qual a questão social é problematizada objetivamente por meio do viés da exploração do trabalho. A classe dos camponeses, novamente através da figura dos ganhões, é aquela que, por meio do seu trabalho, enriquece os grandes proprietários de terra. Porém, a sua força de trabalho não lhe oferece meios de mudança social, isto é, os trabalhadores não recebem o suficiente para modificar sua condição de miséria. Faltam-lhe os bens primários: comida e proteção, além de medicamentos.

Ora, em tal reflexão, Dr. Seabra expressa um pensamento sobre um dos temas mais importantes do marxismo: a noção de exploração. Conforme explica a economista britânica Susan Himmelweit,

Em qualquer sociedade em que as forças produtivas se tenham desenvolvido além do mínimo necessário à sobrevivência da sua população, capacitando-a assim, pelo menos potencialmente para crescer, transformar-se e sobreviver às vicissitudes da natureza, a produção de um excedente torna possível a exploração, que é o fundamento da sociedade de classes. A exploração ocorre quando um setor da população produz um excedente cuja utilização é controlada por outro setor. As classes, na teoria marxista, só existem nas relações que mantêm uma com as outras, e essa relação gira em torno da forma de exploração que tem lugar em um determinado modo de produção. É a exploração que dá origem à luta de classes. ${ }^{67}$ (grifo do autor)

\footnotetext{
${ }^{67}$ Verbete "exploração". In: Dicionário do Pensamento Marxista, p. 235-236. (Versão digital).
} 
Assim, a ideia da "geringonça social" (OLIVEIRA, 2004a, p. 72) levantada por Dr. Seabra nos possibilita uma análise sobre a questão das classes no romance, já que reconhece a situação dos camponeses, relegados à privação e à pobreza.

No quadro da exploração e de suas consequências aos trabalhadores rurais, Carlos de Oliveira cita que a paisagem de sua infância - a terra gandaresa - "não é nenhum paraíso perdido mas a pobreza, a nudez, a carência de quase tudo" (2004b, p. 186). Dr. Seabra dá voz ao viés crítico das relações de trabalho que movimentam o cenário das memórias do autor. A nudez do trabalhador concretiza-se na escassez daquilo que lhe é minimamente essencial para sobreviver ou na sua falta total. A "carência de tudo" é resultado da dinâmica de exploração da força de trabalho, noção que chega ao leitor pelos olhos do médico que não se diz comunista, mas, sim, humano.

Há, nesse panorama, uma problematização sobre a maneira como os trabalhadores são explorados pela elite rural portuguesa através dessa personagem que lida objetivamente com as consequências de tal ação. Apesar disso, o autor de Casa na Duna não elabora essa ideia pela visão dos próprios camponeses. Nesse sentido, ainda que essa temática seja elucubrada pelo médico, não podemos afirmar que ocorra luta de classes no romance. A constatação de Dr. Seabra sobre as circunstâncias de privação dos jornaleiros ilustra, sim, a relação de poder entre classes, pois, mesmo que Mariano Paulo mantenha sua quinta a produzir como há mil anos, as estruturas sociais que compõem esse cenário são pautadas pela exploração. Há a consciência disso por parte das personagens, lembrando que o dono da propriedade julgava-se um pouco responsável pela miséria de Corrocovo, como indica o narrador no capítulo XII. No entanto, para que haja o processo conhecido como luta de classes, é necessário que exista, além da polarização entre dominantes e explorados, a consciência de classe deste grupo, conforme reflexão de tal assunto por Marx e Engels no Manifesto Comunista (2005).

Em tal obra, ambos os pensadores afirmam que a "história de todas as sociedades até hoje existentes é a história da luta de classes" (2005, p. 40), justamente porque os sistemas econômicos baseiam-se em uma gradação de estratos sociais, colocando sempre um grupo na posição de opressor e outro de oprimido, e historicamente tais camadas aparecem em conflito, o que promoveu transformações na sociedade em todos os períodos conhecidos. Ora, a partir desse pensamento podemos pensar no cenário gandarês descrito por Oliveira: de um lado, há o grupo dominante, representado pela família dos Paulos; de outro, os camponeses, ilustrado pelos funcionários da quinta e pelos jornaleiros. Temos, 
naturalmente, uma dinâmica entre as classes, lida pelo autor como algo baseado em uma ordem antiga, que não se alterava "há mil anos".

Conseguimos, assim, observar a divisão das classes no cenário rural gandarês, todavia não se verifica uma tensão entre esses grupos. Não há a ocorrência de uma personagem, por exemplo, que seja líder "das massas”, isto é, dos jornaleiros e demais camponeses. Não há, além disso, forças sociais que mobilizem essas pessoas, elementos que seriam essenciais, de acordo com a literatura marxista, para falarmos em luta de classes na obra. ${ }^{68} \mathrm{O}$ que observamos é a constatação e preocupação de uma personagem advinda da classe favorecida provavelmente - o Dr. Seabra - de que ocorre a subjugação de uma camada que, consequentemente, fica destinada a condições degradantes de sobrevivência.

No desenvolvimento da narrativa, acompanhamos a precariedade da situação em que vivem os camponeses de modo geral, e não exatamente a partir de um núcleo específico de personagens. Temos, porém, certa proximidade com a vida de Palmira, cujo percurso de vida ilustra uma das possibilidades do grupo menos favorecido: a emigração. Empregada da quinta dos Paulos, ela se torna responsável pela criação de Hilário após a morte de D. Conceição, sua mãe. Mas ela nutre o desejo de casar-se e engravidar, o que fica evidente no capítulo VII:

As mulheres que trabalhavam na quinta ou vinham trazer a merenda aos jornaleiros, grávidas, com os garotos pela mão, faziam-na sonhar. Imaginava-se como elas: prenhas; depois, um filho ao colo, um braço protector em torno dos ombros e o sorriso forte dum homem a fitar a criança. (OLIVEIRA, 2004a, p. 29)

Enquanto trabalhava, invejava as outras mulheres que tinham família formada, o que a tornava uma pessoa cada vez mais silenciosa. Todo o dinheiro que recebia como pagamento de seu trabalho era guardado e, ao juntar uma quantidade razoável, ela comprava, nas feiras de Corgos, artigos em ouro. Firmino, outro empregado da quinta, dizia-lhe que deveria se casar, pois "com o baú cheio de oiro, não lhe faltam homens" (Ibid.).

De fato, foi o que Palmira fez: casou-se com o jornaleiro Luciano Taipa, que “averiguou ao certo as libras e os cordões do baú” (Ibid.) e então começou a namorá-la. Perto de se casar, ela pediu a Mariano Paulo sua demissão, pois iria se casar. Hilário percebeu que Taipa tinha interesse na renda dela, mas não lhe disse nada, afinal não nutria

\footnotetext{
${ }^{68}$ Conforme ilustra o verberte “Luta de Classes”, no Dicionário do Pensamento Marxista, p. 355.
} 
afetividade pela mulher que o criara. Ela partiu tristonha, enquanto o menino observava a situação sem o menor interesse. E o dono da quinta reforçava: "Ninguém a pôs na rua" (Ibid.).

A sina de Palmira depois de casar-se mostra que a condição do camponês em Corrocovo era difícil. Com o dinheiro que ela juntou, o casal comprou um "pedaço de terra" e começaram a cultivá-lo "cheios de esperança" (Ibid., p. 41). Enquanto isso, ela cuidava de sua sogra, uma senhora com aparente problema de locomoção. Ao falar da mãe de Luciano, o narrador une à ideia de precariedade da pequena propriedade uma descrição de repugnância: "A velha chamava. Palmira mudava-lhe a roupa molhada. Fitava Luciano e suportava sem custo o cheiro da palha apodrecida pela urina. Virava o corpo meio morto, estendia uma coberta enxuta sobre o enxergão" (Ibid.). A situação em que a velha senhora ficava é descrita por um viés que pode suscitar certa repulsa do leitor:

A velha ficava todo o dia sozinha. As moscas voavam das estrumeiras,
zumbiam na sombra do casebre. Réstias de luz entravam pelas telhas
desconjuntadas, abriam no soalho minúsculos lagos amarelos. Nesses
raios de sol a poeira brilhava e as asas rápidas das moscas passavam de
vermelho a azul, de verde a roxo. Cores ágeis, inquietas. A velha
pensava em Luciano, em Palmira, e rezava por eles. (OLIVEIRA,
2004a, p. 42)

Nesse trecho, o contraste entre o movimento das moscas e a imobilidade da senhora intensifica a condição degradante em que ela se encontra. O detalhe do cheiro da urina não é dado somente como uma simples descrição, e sim um fato essencial para que o leitor forme o quadro narrado: ainda que cheiro fosse asqueroso, Palmira aguentava-o "sem custo". Nisso encontra-se a satisfação dela na sua nova situação de estar casada e ter uma pequena propriedade.

A nova trajetória da ex-empregada da quinta não é um mero detalhe do enredo, nem a cena descrita se configura como uma "digressão" dentro do seu conjunto, utilizando a expressão de Lukács no famoso ensaio "Narrar ou Descrever?", no qual analisa a pertinência dos momentos de descrição dentro da construção de uma narrativa (1965, p. 44). No texto, o autor compara um momento de narração de uma corrida de cavalos escrita por Émile Zola, em Nana (1879), a outra escrita por Liev Tolstoi em Ana Karenina (1977). No primeiro, é feita uma descrição detalhada do evento em seus pormenores. Porém, o pensador observa que "esta descrição, com todo o seu virtuosismo, não passa de uma digressão dentro do conjunto do romance", tornando os eventos descritos facilmente desconectados ou suprimidos da trama (1965, p. 44). 
Em Ana Karenina, no entanto, a descrição ocupa uma função primordial no desenvolvimento da narrativa segundo o crítico húngaro. "A corrida de cavalos de Ana Karenina é o ponto crucial de um grande drama. A queda de Wronski representa uma reviravolta na vida de Ana" (Ibid.). Desse modo, ele observa que as relações entre as principais personagens do romance passam para uma nova fase após a corrida, a qual se torna uma espécia de "drama psicológico" (Ibid., p. 45). Tolstoi teria, por meio da descrição do evento, "evitado a causalidade nua e crua, elevando-a ao plano da necessidade" (Ibid., p. 46), uma vez que ela promove mudanças dramáticas na narrativa. Não seria assim somente um mecanismo para explorar o ambiente onde se passa a ação, mas, sim, um elemento que propicia uma reviravolta no enredo, sendo um componente essencial à tragédia que elaborada.

Desse modo, ao descrever as condições de vida da empregada Palmira, não estamos diante de uma causalidade descrita por Oliveira, não é algo que pode ser suprimido da narrativa. A descrição de tal contexto é essencial para se construir uma visão sobre a relação de classes no romance. A reflexão suscitada pelo autor liga-se, assim, aos elementos descritos. "Preciso quase sempre de imagens [...], não desisto de ligar tudo o que penso ao mundo comum, cotidiano: os objetos, a paisagem, os homens", observa o escritor em seu ensaio "Imagem Turva" (2004b, p. 27). O que é descrito desperta a compreensão do leitor para que, de um lado, possa perceber a situação de precariedade em que os desfavorecidos vivem e, de outro, o alheamento a essa condição por parte do camponês ou do trabalhador - o que nos ajuda a pensar o modo como ele vislumbrou trazer as personagens assalariadas, uma vez que não lhes é dada uma consciência de classe no livro.

A questão da vivência precária ilustrada na nova vida de Palmira é presente, ao longo de toda a obra, em descrições feitas pelo narrador. Assim, na leitura, temos o contato com tal panorama para além das constatações de Dr. Seabra. Ademais, essa aproximação é feita também pelo fato de grande parte dos capítulos ser aberta com informações descritivas das circunstâncias em que Corrocovo está inserida, nomeadamente aspectos ambientais. O capítulo XI, por exemplo, comporta essa perspectiva ao ser iniciado com um relato descritivo da ação do tempo naquele local:

As colheitas não compensaram. Chuvas fora do tempo apodreceram metade das raízes e o sol quando veio continuou a destruição. Nevoeiro, 
míldio ${ }^{69}$, lagartas e calor, isto é, doenças a grassar no chão macerado. $\mathrm{O}$ vento quente matava as culturas, matava por sua conta. A terra, que era verde, tornara-se amarela (OLIVEIRA, 2004a, p. 43).

Assim, há dois movimentos que se observam: as mudanças do meio ambiente e a sua consequência à terra e aos habitantes do local.

A ação do tempo ocorre em etapas: primeiramente o excesso de chuvas apodreceu as plantações, favorecendo a criação de pragas que também as destroem e provocou o acúmulo de água suja nos locais, causando doenças. Em seguida, o tempo quente terminou a destruição e ainda levou à proliferação de mais pragas à seca. Diante de tal cenário, Luciano Taipa e Palmira tentavam regar sua plantação, mas nada do que faziam era suficiente, pois a água diminuíra excessivamente. Os milhos plantados eram atacados por bichos, e o camponês olhava desolado para seu terreno.

Após descrever o esforço do casal para tentar aplacar os efeitos da seca e das pragas, o narrador nos oferece a descrição do que se passa na propriedade de Mariano Paulo: "Pela quinta, ia um movimento desabitual. O gado andava todo no trabalho, fazendo rodar os espigões dos engenhos de manhã à noite. Bois, cavalos esfalfados" (OLIVEIRA, 2004a, p. 44). Há uma comparação possível de fazer nesse trecho: em um parágrafo, observamos que Luciano Taipa senta-se, suado e cansado, para olhar desolado sua terra. Já na propriedade grande, os animais estão fatigados de tanto trabalhar.

Ora, os proprietários de "pedaços de terra", como o casal Taipa, e os camponeses que trabalham à jorna em Corrocovo estão diante da ação do meio ambiente do mesmo modo que o núcleo dos Paulos. Porém, evidencia-se nesse capítulo uma diferença expressiva: Mariano Paulo conta com recursos para lidar com os efeitos da natureza, enquanto o casal não. Temos no destino de Palmira e de seu marido a ilustração de como a ascensão socioeconômica lhes é negada: ainda que tenham tido dinheiro para adquirir um pequeno terreno, eles não contam com mais nenhuma possibilidade, além da sua força de trabalho, para fazer sua agricultura prosperar, o que se demonstra insuficiente, pois a família, após essa má colheita, acaba por se endividar e perde a terra.

Naturalmente, um pequeno proprietário não teria como competir, na venda de produtos agrícolas, com Mariano Paulo e outros lavradores que contam com meios de produção - ainda que arcaicos, como os animais - e mais empregados. Mesmo com a diminuição do calor, a situação é irremediável: as colheitas foram quase perdidas, o que

\footnotetext{
69 Míldio é um tipo comum de fungo que parasitam plantas terrenas, destruindo-lhes o sistema reprodutor, conforme o verbete no Dicionário Eletrônico Houaiss.
} 
significa um inverno de muita fome segundo o narrador (Ibid., p. 47). Para lidar com o problema, Luciano endivida-se na mercearia de Miranda, comerciante que ganha à custa da dificuldade dos camponeses. Ele comprou adubo e sementes confiante na colheita, que fora destruída. Porém, sua dívida permanece e o casal perde sua pequena propriedade, restando-lhe apenas uma alternativa: emigrar. Talvez Palmira tenha que voltar a ser empregada, talvez tenha de se destinar ao trabalho dos jornaleiros, como muitas pessoas da Gândara, ilustrando o "painel tantas vezes brutal do trabalho camponês: ranchos de mulheres cansadas, [...] rostos saibrosos de cavadores. O suor de sol a sol: 'Enxada à terra, ó braços da pobreza"”, como observa Carlos de Oliveira (2004b, p. 15) em seu ensaio "A Dádiva Suprema", presente em O Aprendiz de Feiticeiro.

Apesar de ter conseguido comprar um pequeno terreno, a trajetória de Palmira não indica uma mobilidade econômica de fato e ainda aponta para a situação de privação desse grupo diante do contexto em que estão inseridos. Estão subordinados a um regime de trabalho insatisfatório em termos financeiros, que promove uma sobrevivência cheia de percalços. Estão também à mercê das mudanças ligadas à chegada do capitalismo industrial na região e ao aprimoramento da infraestrutura, pois, ao afetar os donos dos meios de produção, prejudica-se diretamente aqueles que deles dependem. E estão, ainda, subjugados à ação do meio ambiente, uma vez que não contam economicamente com a possibilidade de lidar com os efeitos naturais, como colheitas perdidas e proliferação de doenças.

Nesse âmbito, as descrições do ambiente são essenciais para o leitor perceber que a situação de pessoas como Palmira e Luciano está inserida em uma circularidade, a qual acompanha o ciclo das estações do ano. No decorrer dos capítulos, observamos a progressão temporal em oposição à imobilidade da vida em Corrocovo. No capítulo VIII e IX, por exemplo, o narrador nos indica o efeito do estio naquela paisagem, com muitas chuvas inesperadas. Em tal cenário, doenças e pragas propagam-se, atingindo os mais pobres. No capítulo XII, o outono chega, o calor diminui, mas os habitantes da propriedade deparam-se com as colheitas quase perdidas, ou seja, um prenúncio de tempos de privação no inverno que se aproxima. Já no capítulo XIV, o frio se instala, trazendo fortes tempestades, a fome decorrente da má produção e, inevitavelmente, doenças, ou seja, mais privação.

As alterações do meio ambiente contrastam com a continuidade da situação precária naquele local, o que nos faz pensar na fala do narrador na abertura do capítulo XV: "A quinta parecia viver fora do tempo. Numa pausa do tempo" (OLIVEIRA, 2004a, 
p. 61). A natureza alterna-se em um ciclo, mas a quinta não: a produção ocorre como há mil anos e os camponeses estão em privação desde sempre. É a esse aspecto que Gonçalo Duarte se refere como tempo iterativo, isto é, um tempo de reiteração que dá ao cenário uma perspectiva de indeterminação (2008, p. 106). No entanto, diante da iteração, colocase um movimento: a transformação socioeconômica trazida pela mecanização e aprimoramento da infraestrutura, configurando-se como uma antítese à permanência. A quinta, onde "tudo nascia da sua paciência" (Ibid., p. 35), já não pode continuar a mesma. Enquanto isso, passa-se o tempo e a miséria da região mantém-se e reproduz-se - como demonstrou o fracasso de Palmira e seu marido.

Mesmo que a trajetória da ex-empregada da quinta nos permita compreender a situação de miséria em que a classe desfavorecida permanece, não temos na sua narrativa a presença de uma consciência de classe, o que leva alguns críticos a considerarem que o conflito de visões de mundo em Casa na Duna não é tão ativo, como aponta Gonçalo Duarte (2008, p. 61). A tensão, segundo esse autor, cria-se no próprio processo de derrocada da quinta dos Paulos, causando o fim de um "mundo que nos foi apresentado como inteiramente consolidado (e por todos aceite como natural)", o que desmistifica tal realidade (Ibid.). Tal perspectiva é criada pelo papel ativo do leitor, que une os elementos relatados à voz reflexiva de Dr. Seabra e depreende, assim, a intensa polarização do livro.

$\mathrm{Na}$ leitura, portanto, constrói-se o conflito entre os grupos engendrado pela chegada da modernização no ambiente gandarês. Nota-se, desse modo, que o advento da mecanização e o desenvolvimento industrial naquele local vai promover mudanças que não atingem apenas o núcleo de Mariano Paulo, mas, sim, toda a ordem social estabelecida. Marx e Engels observam que "a burguesia não pode existir sem revolucionar incessantemente os instrumentos de produção, por conseguinte, as relações de produção e, com isso, todas as relações socias” (2005, p. 43). É justamente nesse movimento que Carlos de Oliveira nos oferece uma reflexão sobre a condição de vida dos trabalhadores subjugados ao poder econômico. As consternações do herdeiro do velho Paulo referemse à dissolução da ordem social há diversos anos estabelecida. A "pausa no tempo" se desfaz, e o leitor coloca-se a pensar na relação entre as camadas sociais que tem como consequência a miséria e a exploração. "Tudo o que era sólido e estável se desmancha no ar, tudo o que era sagrado é profanado e os homens são obrigados finalmente a encarar sem ilusões a sua posição social e as suas relações com os outros homens" (Ibid.).

O panorama então divide-se: de um lado, há a elite rural com suas preocupações e busca pela manutenção de uma ordem dominante, de outro, os camponeses "numa 
grande solidão de areia" (OLIVEIRA, 2004b, p. 186). Este é o cenário também que se apresenta na leitura de Pequenos Burgueses (1948). O polifônico romance de Oliveira já indica em seu título uma abordagem, em princípio, de classe. Curiosamente, apesar de o título suscitar essa ideia, o livro foi mantido em esquecimento pelo autor de acordo com Santilli (1979, p. 150), mesmo que tenha sofrido modificações importantes entre a primeira e segunda edição no que tange ao quadro marxista elaborado a partir das micronarrativas em torno de Fonterrada. A paisagem gandaresa é recuperada pela quinta do Major, exercendo uma centralidade na região semelhante à propriedade de Mariano Paulo.

Em tal obra, o autor parece vislumbrar a análise de um aspecto comumente relacionado às características de uma sociedade estratificada: o desejo de ascensão social. Assim, oferece-nos "sucessos relativos à vida portuguesa provinciana" (SANTILLI, 1979, p. 151) em contraste com os anseios de uma camada mais desfavorecida, personificados em Raimundo e, em certa medida, em Marciano - funcionário do armazém que espera tornar-se gerente e, então, aceder ao mundo dos (pequenos) burgueses. Temos a oposição entre necessidades, aspirações e preocupações da elite e da camada mais baixa dessa região. Santilli observa que "o romance objetiva, então, sobretudo essa classe social 'mediana' que talvez pudesse desde logo identificar-se, aqui, como 'medíocre' e 'mesquinha'(Ibid.).

Porém, na teia de relações sociais construídas pelo autor nesse romance, observamos não somente uma dicotomia entre ricos e pobres. Ocorre o desenvolvimento mais complexificado das camadas sociais. Há hegemonicamente a elite, expressa nas figuras do Major, do Delegado e de D. Álvaro, por exemplo. Em oposição, temos personagens que vivem de forma muito precária, como o adivinhador de rastros Raimundo. Há ainda uma classe mediana, tanto mais favorecida - como a personagem estrangeira e misteriosa de Pablo Flórez - e a menos abastada - como Marciano, que é um funcionário do armazém, mas vive ainda relegado à submissão dos grupos mais poderosos. É, portanto, um quadro mais complexo e detalhado, o que nos permite uma análise detalhada do modo como as classes se relacionam nesse contexto.

Ora, de que modo tal contraste poderia revelar uma ideia de exploração em Pequenos Burgueses se temos como foco a pequenez dos pensamentos de uma camada consolidada e abastada? Seria, de fato, tal romance um indicador do desvio de Oliveira do movimento neorrealista? Tentaremos abordar esses questionamentos na análise da temática de classes - e, por consequência, a exploração - na obra, considerando que o 
livro é visto como um forte exemplo da transformação de um Neorrealismo mais ortodoxo em um movimento que convoca o leitor para construir a crítica e a reflexão, como afirma Lélia Duarte (1998, p. 94).

Logo em uma primeira leitura, constatamos que esse romance se configura em torno das relações de interesse que movem a sociedade rural gandaresa retratada. Nos relatos das personagens e na introspecção psicológica que lhes é dada, o leitor coloca-se diante de um "quebra-cabeças", articulando o modo como cada uma das histórias é parte de um quadro maior de crítica conforme a visão de Oliveira sobre a exploração e a dominação dentro do grupo dos pequenos burgueses e da classe desfavorecida a ela subjugada. O desejo de posse e de poder é o elemento central que une as micronarrativas, sugerindo-nos justamente o ponto de partida de análise sobre tal temática.

No plano do grupo mais favorecido, temos duas figuras que explicitam o anseio de posse e poder: o Major e o Delegado. Em princípio, pelos títulos, já observamos o lugar poderoso em que ambas as personagens se encontram. Além de sua condição econômicas, ambos são elementos de força do Estado, representando a autoridade - e, no contexto salazarista vivenciado pelo autor - o autoritarismo. Na hierarquia militar, “major" é um posto de poder superior, estando apenas abaixo do tenente-coronel, e referese a uma função de chefe de Estado ou de uma unidade militar. É, assim, um dos principais representantes das Forças Armadas de um país. O papel de delegado, por sua vez, é também um representante, porém ele expressa o poder de um governo e do Estado para atuar na polícia como o poder e a força dessas instituições. Desse modo, ambas as patentes revelam a noção de autoridade. No cenário de uma ditadura militar, como ocorria em Portugal na época em que se passa o livro - período da $2^{\text {a }}$ Guerra Mundial - observamos que se vinculam a essas funções ideias de opressão e violência, resultantes do autoritarismo do poder central estatal.

Nesse sentido, o Major, dono da quinta de Fonterrada, exerce o poder atribuído pelas Forças Armadas e, possivelmente, isso é estendido a seu papel como proprietário rural, algo que pode ser semelhante ao coronelismo brasileiro, isto é, uma prática de poder política-social presente em comunidades rurais na qual uma elite controla o cenário apoiada em na função militar dos proprietários de terras. É uma forma de ampliação e extensão do poder que o indivíduo tem no Exército na configuração das comunidades agrícolas. Porém, não temos em Pequenos Burgueses um detalhamento acerca desse aspecto. Na trama, o foco de poder dessa personagem se dá em âmbito pessoal. Ele se encontra em um momento de redescoberta da sua virilidade: enquanto seu casamento com 
D. Lúcia sobrevive apenas pelas aparências, ele mantém uma relação extraconjugal com a jovem costureira Rosário. Extremamente sensual, a moça exerce um forte poder de atração sobre ele. Quanto mais seu caso se fortalece, mais repugnância pela esposa ele sente. O discurso indireto livre permite ao leitor mergulhar na consciência do Major, que sente náuseas pelo cheiro da esposa envelhecida e julga o leito em que dormem como um "pântano" (OLIVEIRA, 2005, p. 20).

Tal personagem seria, então, "o garanhão retraído em função da velhice da esposa" (DUARTE, 1998, p. 95), que fora recuperado pela juventude e sensualidade da costureira. Em uma analogia cruel, ele compara a esposa a uma "pirisca" de cigarro - a ponta que sobra desse objeto depois de já ter sido utilizado: "É verdade, fui eu que te fumei até o fim como fumo este cigarro. Com mais exactidão, nunca se fuma um cigarro até o fim. Aí está o que tu és, a pirisca a apagar-se, abandonada no cinzeiro. Por muito que me custe pensá-lo" (OLIVEIRA, 2005, p. 20). Nessa comparação, observamos, de um lado, a visão do Major sobre sua esposa e, de outro, sua noção sobre si mesmo.

Ao observar D. Lúcia como a ponta que sobra de um cigarro fumado, o Major coloca-se em uma posição de poder diante dela. Foi ele quem a utilizou, quem se aproveitou da esposa enquanto ela tinha algo a oferecer: jovialidade e sensualidade. No entanto, isso não pode mais ser oferecido por ela dada a implacável passagem do tempo e a inevitável velhice conforme sua perspectiva. Ele, apesar disso, não se reconhece como uma pessoa que também envelheceu. Pelo contrário, sua virilidade é ameaçada pela esposa que já não exala o cheiro da juventude e da lascívia.

Em sua posição de macho viril e dominante, ele encontra-se "preocupado exclusivamente consigo mesmo e com o tempo que passa [...]" (DUARTE, 1998, p. 95), voltando-se à Rosário de forma obsessiva. O que se observa, então, não é o apelo da paixão entre os dois, e sim o anseio desesperado de manter sua masculinidade e, de certa forma, sua juventude - atributos que lhe colocam em um nível de poder. Obcecado pela amante, o Major revela-se uma personagem ameaçada pelo tempo que passa e lhe tira sua viril posição. Ao relacionar-se com a costureira, o desejo de poder - sobre a mulher e sobre o tempo - concretiza-se, além do interesse pela posse, pois é ele quem a sustenta. Temos, desse modo, o domínio do vigor masculino imbricado no poder financeiro.

O outro lado da relação de poder exercida pelo Major é visualizado no sofrimento de D. Lúcia, que observa seu envelhecimento e indiferença do marido de maneira desesperada. O caráter opressor do marido expressa-se através da obsessão dela pela aparência física, construindo-se proporcionalmente à repugnância que o marido sente por 
ela, ou nas palavras dele, "a náusea insidiosa" (OLIVEIRA, 2005, p. 20). Ela deseja ir a um especialista em Lisboa que possa tratá-la do cheiro que adquiriu com a idade, afastando-a do esposo, porém ele não lhe dá a atenção necessária nem para acompanhála. Como resposta a tal desalento, ela pensa em suicídio - porém, não deseja morrer, e sim atrair a atenção dele, afinal suicidar-se é pecado dentro do pensamento moral e religioso cristão.

Nesse contexto, podemos considerar que os desejos expressos pela esposa do Major são da ordem da anulação. Diante dele, ela sente o apagamento da chama do desejo, o que se estende à sua pessoa. Ela se apaga diante do marido, assim como a pirisca, que, após ser fumada, apaga-se sozinha caso alguém não alimente a chama. Apesar de estar ciente da repugnância que ele sente por si, a senhora aceita a situação, colocando-se como culpada por causa de sua idade. A ânsia pelo suicídio revela o desespero de não receber a atenção e o amor do marido, muito menos o seu desejo sexual. No capítulo XXVII, por exemplo, temos o diálogo entre a D. Lúcia e uma voz que lhe incita tirar a própria vida com estilhaços de vidro. Podemos pensar que tal voz é a sua própria, estando ela cindida: de um lado, a intensa necessidade de atenção e afeto. Do outro, o medo de romper com a ordem estabelecida: ser a esposa do Major, mãe de dois filhos jovem e, principalmente, uma mulher temente a Deus.

Ambas as partes dialogam, por meio do discurso direto, expondo o pavor e a tentação de morrer. A voz incitante afirma que o suicídio resolveria os problemas dela e, naturalmente, os do marido. Abdala Júnior (1981, p. 63) observa que o narrador cola-se ao "outro eu" de D. Lúcia, o que permite a objetivação da situação em que ela se encontra, excluindo dela toda a ilusão da personagem, que duela contra si mesma. Ironicamente, enquanto essa discussão mental se passa na sua cabeça, ela segura fervorosamente um rosário - uma referência à religião evidentemente, mas também um mecanismo quase cruel do autor em recuperar neste momento o nome da amante do Major. Ela quer ceder à morte, mas somente se o marido estiver por perto para salvá-la. Assim, em seus desejos e temores, está uma antítese: a resignação da traição do marido e do seu papel de esposa fiel e religiosa em oposição a um forte desejo de chamar-lhe a atenção, ainda que seja através da própria morte. Mentalmente, ela é um misto de anulação e desespero.

Em torno do drama marital e do caso extraconjugal, encontra-se ainda o Delegado, futuro marido de Cilinha, filha do Major, e também amante de Rosário. Valendo-se do seu efeito com as mulheres e da paixão da costureira, ele aproveita a relação para usar o dinheiro dado pelo Major - seu futuro sogro. Essa estratégia é familiar ao Delegado, que 
se recorda de fazer isso quando era mais jovem, nos "tempos de Coimbra", quando se relacionava com uma viúva em troca de dinheiro (OLIVEIRA, 2005, p. 29-30). Seu envolvimento com a costureira é motivado pelo interesse financeiro, uma vez que ele se encontra frequentemente empobrecido em decorrência dos jogos de carta no Café Atlântico.

O Delegado, por meio dos seus pensamentos, explicita seu fingimento diante de Rosário:

Não quero passar por cínico, tenho apenas bastante senso prático e sei manejar uma mulher. De resto, é fácil. Toco-lhe no seu ponto fraco, com delicadeza, já se vê, e uso um truque psicológico infalível: mostrome tão interessado como ela naquilo por que está a morrer (Ibid.)

Aproveitando-se do desejo da jovem, ele a instiga sexualmente e, então, pede-lhe dinheiro emprestado. Ainda que tenha consciência dessa ação, ele pensa: "O meu problema mistura-se muito bem misturado a estes gemidos" (Ibid., 2005, p. 30). Como verifica Lélia Duarte, ele se coloca como um explorador de mulheres, afinal elas são, como dizialhe um amigo da faculdade, “-Éguas, pá, para montar. E mais nada” (Ibid., 2005, p. 31).

Nesse triângulo amoroso, mesclam-se o desejo de poder e de posse que são encobertos pela tentativa de se manterem as aparências diante da sociedade. Enquanto o Major vê a necessidade de continuar sua relação com D. Lúcia pelos filhos, Rosário preocupa-se com o fato de os vizinhos verem que, em sua casa, alternam-se os amantes. Contudo, eles já comentam com naturalidade tal situação, fazendo brincadeiras com a ideia de que estão em família. "Salvaguardadas as aparências familiares, mantido o fingimento, estará tudo bem", afirma Lélia Duarte (1998, p. 96).

$\mathrm{O}$ discurso indireto livre como mecanismo de narrativa permite um aprofundamento psicológico das personagens, oferecendo mais elementos para pensarmos as relações sociais estabelecidas no contexto. Externamente, a relação tripla entre Major, Rosário e o Delegado é escondida - parcialmente, convenhamos - afinal, ela se configura de modo imoral - segundo os padrões da sociedade -, seja pelo casamento, seja pelo futuro compromisso com Cilinha. O leitor, no entanto, é posto diante das reflexões de cada figura nas suas vozes e seus pensamentos, o que o leva a compreender a maneira como essas aparências se constroem na narrativa. Ora, o contato com o interior das personagens reforça a ideia de fingimento na tentativa de preservar o decoro social que pauta essas relações. Assim, não é necessário um narrador indicando esses aspectos, 
o que reforçaria, por exemplo, a característica dogmática observada por Santilli nas duas primeiras edições de Pequenos Burgueses.

No capítulo XII, por exemplo, ocorre a descrição da cena em que os homens, reunidos no Café Atlântico, jogam. D. Álvaro mantém-se ganhando, enquanto o Delegado pensa em roubar no jogo, afinal era o dinheiro que tinha pegado com Rosário que estava em jogo. Na primeira edição, o capítulo é contado pelo narrador, mas, na terceira, ele se passa mentalmente na cabeça de Plabo Flórez, sendo escrito todo em uma espécie de portunhol. O Delegado continuava a perder, mas, repentinamente fica calmo, conforme descreve a primeira edição:

$\mathrm{O}$ delegado sentiu-se subitamente calmo. O cigarro e o pequeno descanso tinham-lhe feito bem. Passou o lenço na testa suada e disse, apontando a porta por onde Marciano partira: - Foi se o enguiço. Talvez isso agora mude. E mudou. O dr. Albertinho [o Delegado] encheu-se de coragem e experimentou vários truques. Negou-se duas vezes a naipe o que lhe valeu dois jogos. E, entusiasmado pela impunidade, chegou a socorrer-se habilidosamente de trunfos escamoteados às vasas já jogadas. Ao fim da sessão, estava mais ou menos no dinheiro de Rosário. Cá fora, quando se despedia dos companheiros, Pablo Flórez bateu-lhe no ombro e disse naquela linguagem híbrida que o distinguia: -Vamo-nos os dois, doutor. Yo preciso hablar-lhe (OLIVEIRA, 1948, p. 48)

Nesse momento, inicia-se o diálogo direto entre ambos, no qual o espanhol expressa que viu a "batota" e pede-lhe metade dos lucros, em um diálogo em discurso direto.

A terceira edição, no entanto, traz todo o desenrolar da partida aos olhos e ao pensamento de Flórez em misto com a fala do narrador e com o discurso indireto livre relativo ao pensamento do Delegado:

Também o Delegado aconselha calma a si mesmo. Pensa em aplicar um golpe, que remédio, para salvar o dinheiro da prenda de Cilinha. Mede os prós e os contras, hesita, desgasta-se, fuma desalmadamente. Como está num dia em que parecem ressucitar por atacado os antigos pecadilhos de Coimbra, não mais que pecadilhos, pondera ele, resolvese por fim. [...] Pois bem, chegou a altura. Escrúpulos neste pinhal da Azambuja para quê? Demais a mais, quem me garante a mim que eles jogam com honestidade?

[...] El Delegado negou-se a espadas em la outra basa e ahora la tiene. Bueno, bueno. Mi conocida impassibilidade continua. Pocas palavras, manos, maos, mãos sem nenhum tremor, caramba, que português casi universitário, indiferência, la manha de los antigos Flórez com sus carroças e tendas por caminos fuera. El Delegado ocultou hasta ahora su verdadeira propensión. Que tio, que descaramento. [...] Muy bien. Ahora, ouve: se quisieras dar um murro em la mesa e outro neste viagrista que no tiene mas tiene espadas, que obscenidad escolherias para decir, dicer, dizer? No lo sabes, claro, porque no hay palavra 
bastante salgada para la emergência. E se houvesse, no las dirias porque es el hombre de piedra. Los hombres de piedra no hablam. [...] No desmanches tu serenidad. Hablarás quando llegar el momento (OLIVEIRA, 2005, pp. 58-59)

Nos quatro primeiros períodos, a fala é do narrador, mostrando que o Delegado pensa em dar algum golpe para escapar da derrota e da perda de dinheiro. Em seguida, já observamos o discurso livre, pois a fala do narrador mistura-se à do homem que perde. Em seguida, observamos o diálogo mental de Pablo, que observa toda a trapaça, o que é linguisticamente denotado com o uso do portunhol. Os homens então saem e Flórez chama o Delegado para desmascará-lo, o que se mantém em discurso direto.

Na primeira edição, o Delegado - chamado ainda de Dr. Albertino - pratica a trapaça implicitamente, o que nos é mostrado pela voz do narrador. Percebe-se que Pablo detectou o golpe a partir do discurso direto, quando o chama para conversar a sós. $\mathrm{Na}$ terceira edição, a mudança é notável. O prenúncio da batota é feito através do pensamento do Delegado em fala misturada ao do narrador. Em seguida, o turno é passado para o Flórez, que observa toda a ação e emite um juízo de valor sobre o homem que estava perdendo e, de repente, salva-se. No pensamento do espanhol, expressa-se a ideia das aparências: o Delegado não demonstrava tal caráter, mas sempre o tivera: "El Delegado ocultou hasta ahora su verdadeira propensión. Que tio, que descaramento". É um modo de tornar o papel do narrador menos direcionante. As próprias personagens revelam-se e revelam as outras por meio do pensamento explicitado em turnos de fala misturados ao do narrador.

Esse recurso torna-se muito profícuo para desvelar as aparências que constroem as relações sociais em Fonterrada. Ademais, o discurso indireto livre insere objetivamente o discurso em quem o produz, dando à personagem uma tomada de posição, como observa Bakhtin (1981, p. 121). Isso permite que Oliveira transmita exatamente o sentido de relação de poder e de jogos de interesses, a exemplo da figura do Delegado. No caso do Major, a opção por manter o relacionamento por decoro expressa a posição social dessa personagem diante de sua própria classe, dando ao leitor subsídios para formar sua reflexão a partir de uma experiência que lhe surge de forma mais concreta e explícita.

Nesse aspecto, o escritor da "Tetralogia da Gândara" engendra uma mudança extremamente significativa na sua revisão de Pequenos Burgueses ao optar pelo discurso indireto livre, uma vez que tal estratégia promove uma espécie de estranhamento na leitura. Isso ocorre porque esse recurso permite marcas de expressão subjetivas que se distanciam, normalmente, daquelas do narrador. Ao observarmos essa mudança repentina 
da linguagem de outrem, aquilo que é contado ganha automaticamente um maior destaque, como analisa Bakhtin: “[...] um estranhamento que se dá justamente na direção que convém às necessidades do autor: elas adquirem relevo, sua "coloração" se destaca mais claramente, mas ao mesmo tempo elas se acomodam aos matizes da atitude do autor - sua ironia, humor etc.” (1981, p. 123). A exemplo dessa sensação, podemos verificar o seguinte trecho no qual o Delegado pensa sobre Cilinha:

Precisa de ponderar o seu namoro com Cilinha. Chama-se a isto associação de ideias. Coitada, parece uma égua triste, alheia ao próprio corpo, que seria o duma fêmea em cheio se houvesse algum fogo lá dentro. Mas desconfio que não há. Como é que o pode saber ao certo? Estes pequenos burgueses, quando se trata das filhas, põem-lhes o cinto da castidade à nascença e guardam a chave. (OLIVEIRA, 2005, p. 31)

Observamos que a fala do narrador cede seu turno ao pensamento da personagem no terceiro período: "Coitada, parece uma égua triste [...]", pois o recurso de comparação das mulheres ao animal acompanha o modo de se expressar do Delegado ao lembrar-se do amigo que as chamava de "gado". O narrador aparece para indicar que a personagem fez uma associação de ideias e, em seguida, surge a reflexão animalizante sobre Cilinha feita pelo homem. Essa mudança causa um estranhamento na leitura, afinal o leitor não está diante de um narrador que expõe suas próprias reflexões, ainda mais classificando a moça a uma égua. Desse modo, essa visão sobre a menina provoca um choque, o que destaca e intensifica a perspectiva do Delegado.

O texto de Oliveira, assim, "teria seu instituto de verossimilhança fundamentado, pelas parcelas de opinião interessadas, esclarecidas e não alienadas, por oposição às de registro no texto", conforme analisa Santilli (1979, p. 158). Ao mesmo tempo, a visão contestadora sobre uma classe dominante não advém da voz do autor objetivamente, e sim do processo de construção textual proposto por ele em conjunto com o seu leitor, criando-se uma narrativa complexa que não dita uma verdade, mas promove uma reflexão crítica. Assim, não se apontam "sentidos, caminhos ou soluções” para quem lê, oferecese um "convite para que veja a situação por um outro ponto de vista, capaz de perceber o que ali existe de simulacro, de representação e de tessitura conscientemente elaborada" (DUARTE, 1998, p. 93).

Nesse papel mais ativo, o leitor depara-se, em Pequenos Burgueses, com personagens estruturadas a partir de jogos de interesse, fingimento e exploração de outros indivíduos. Segundo Lélia Duarte, "cada uma tem a sua história de egoísmo e trapaças, em que os outros são usados na medida de sua utilidade e certamente de sua tolice e 
incapacidade de fazer uma leitura atenta, o que os transforma em cômodos degraus para a ascensão social” (1998, p. 96). É a partir justamente da ideia de mobilidade social que surge a temática da exploração.

Tal aspecto, por exemplo, é concretizado nas micronarrativas de duas personagens: D. Álvaro e Marciano. Ambos pertencem a grupos sociais distintos, mas permitem uma reflexão sobre como uma sociedade estratificada promove o desejo de ascensão a qualquer custo. D. Álvaro, um dos homens que compõem a mesa de jogos do Café Atlântico, é visto socialmente como um comerciante de montarias que pratica qualquer negócio para efetivar sua venda. Por isso, no terceiro capítulo, Raimundo lembra-se dele como o "cigano de cavalos" (OLIVEIRA, 2005, p. 16). Em torno dessa figura, é exposta uma reflexão acerca da "batota", ou seja, a fraude em jogos, ou a nossa “trapaça”, sendo descrito como "jogador até a alma” (Ibid., p. 51). Ele se reconhece, no âmbito dos negócios, como um trapaceador. Porém, não nos jogos. Para ele, o jogo é algo comparável ao divino, justamente pelo acaso, que coordena o destino dos jogadores: "Senta-se, mergulha na tensão do jogo, como se mergulhasse no mistério da missa, e tenta compreendê-lo. Aceita a divindade, quer dizer, o acaso, mas não deixa por isso de o interrogar ou corrigir, quando pode, e em geral sai-se bastante bem" (Ibid.). Seu sucesso suscita nos companheiros de jogo a desconfiança - algo que se refere ao seu caráter como vendedor.

No capítulo XI, o ritmo da prosa é interrompido para que o narrador faça uma lista sobre alguns dados biográficos de D. Álvaro, um procedimento que rompe com os padrões literários por ser "tradicionalmente alheio à literatura", como observa Abdala Júnior (1981, p. 61). A sua família vem da nobreza, no entanto as gerações perdem aos poucos a fortuna acumulada e, no século XIX, o nome familiar está envolvido em "escravatura em segunda mão, rapto de negros no interior e venda em S. Paulo" (OLIVEIRA, 2005, p. 52) e outras informações incompletas. Já em meados do século XX, D. Álvaro herda uma série de dívidas de seu pai, mas consegue liquidá-las quando vende um velho cavalo a um "tolo endinheirado" (Ibid.). Desde tal transação, a personagem consegue recuperar-se financeiramente e investir nesse nicho, condensando, por um lado, o prestígio da herança de fidalgo e, por outro, o poder econômico.

Ora, tal personagem consolida em si traços que são característicos de famílias nobres e aristocráticas - o reconhecimento social e o acúmulo de capitais. Todavia, a influência e o suposto prestígio de D. Álvaro contrastam com a história de seus antepassados e com a obscura forma de negociação que pratica em seu comércio. 
Novamente, Carlos de Oliveira suscita a reflexão sobre o status social e poder que um indivíduo tem dentro de um sistema social, o que se associa, mais uma vez, às ideias de fingimento, aparência e relações por interesse, já visualizadas no Major e no Delegado.

Há uma história muito ilustrativa do caráter desse negociante, contada a Raimundo pelo Mestre Horácio, "afamado ferrador" que "realiza com amor e competência a sua atividade" (DUARTE, 1998, p. 96). A narrativa da mula cor de mel refere-se a um suposto acontecimento na vida de D. Álvaro. Há muitos anos, ele deparou-se com um "parvo que lhe queria impingir a mula mais lazarenta que o fidalgo tinha visto na sua vida" (OLIVEIRA, 2005, p. 72), dizendo-lhe que era um animal espetacular. O comerciante, então, faz-se de enganado e compra a montaria, velha e malcuidada, com a condição de que o vendedor, se precisasse de uma nova mula, só compraria de D. Álvaro. O tempo passa e, de fato, o tal vendedor parvo volta para comprar-lhe um animal, fingindo estar interessado na montaria velha que lhe havia vendido. O cigano de cavalos, claro, não se deixa enganar e oferece outro animal, cor de mel, que estava "gordo, loiro e escovado" (Ibid., p. 73), cujo preço era o dobro da primeira mula.

O vendedor parvo fica encantado com a nova montaria e aceita a compra. Chegando em sua propriedade, mandou que seus funcionários lavassem-na. Então, a trapaça - ou vingança - de D. Álvaro ocorre: [o criado] esfregou-a, tornou a esfregá-la, e tanto esfregou que o espertalhão ia caindo para o lado com um ataque. A mula estava a destingir-se" (Ibid., p. 74). Na realidade, o animal estava doente, mas havia sido bem alimentado e cuidado por D. Álvaro, que o tingiu e o repassou ao seu antigo dono. A micronarrativa de Mestre Horácio leva o leitor a ter contato de forma irônica com o modo como o fidalgo comercializa, sendo um elemento a mais para que se teça essa escrita a partir da reflexão sobre o caráter interesseiro e antiético de tal personagem. A ironia, agora em um nível mais profundo, reside justamente no status social que o comerciante mantém dentro dessa comunidade a despeito de suas trapaças, mas essa peça é montada pelo leitor, não pelo narrador.

Marciano, por sua vez, expressa em sua micro-história o desejo de ascensão socioeconômica em uma sociedade de classes. Alexandre Pinheiro Torres se refere à personagem como "uma das maiores criações de Carlos de Oliveira" (1967, p. 269), constituindo-se como "o pequeno-burguês típico" (Ibid.). Ele trabalha como caixa nos Armazéns São Jorge e acompanha, como um ambicioso espectador, o jogo de cartas que acontece no Café Atlântico entre aqueles que têm poder aquisitivo. Sua motivação é 
especificamente tornar-se o gerente do armazém em uma tentativa de ascensão de status social, o que lhe daria ingresso à roda do baralho dos burgueses.

Sua aparição no romance é extremamente significativa no que tange à ideia de posição social. No capítulo X, Marciano está observando o jogo, por isso sabe que é um “mirone", isto é, pessoa que somente assiste à partida, mas nunca participa dela, e voltase com raiva ao Delegado, que está perdendo. No pequeno conflito entre o observador e o jogador, revela-se uma tensão entre classes. Pensa Marciano sobre o Delegado:

Perde e perderá. Deus ainda escreve direito por linhas tortas. Uma noite, nesta mesma sala, porque me intrometi no jogo, bem sei que não passo de um mirone, dum simples tolerado, mas seja como for, o tipo atreveuse a dizer-me: - Você já reparou que tem um i a mais no nome, Marciano? (OLIVEIRA, 2005, p. 47)

A ironia do jogador com o nome de Marciano refere-se à palavra "marçano", isto é, aprendiz de caixeiro, o que retoma o passado deste e, evidentemente, sua posição socioeconômica. Ao observar o jogo, o caixeiro mistura em si a raiva concernente à sua origem mais humilde e o desejo de ascender socialmente para então poder compartilhar do mesmo jogo com aquele que o humilhou.

Essa personagem é "incapaz de ascender à compreensão de uma problemática de classe" conforme explica Torres (1967, p. 259) e, para poder atingir uma nova posição dentro da sociedade, é capaz de tomar qualquer atitude. Seu desprezo pelo passado de marçano o mobiliza na raiva que sente pelo Delegado, quer dizer, pela posição que este ocupa e aquele não pode, pois tem uma origem pobre. Ver a partida de cartas não é seu interesse:

Estou-me nas tintas para o jogo. O que me traz aqui são estas cadeiras estofadas de coiro verde, com pregaria de cobre. Significam o direito de usar o i no nome, sem referências ao passado. Hei de sentar-me numa delas, podem ficar certos disso, meus amigos (OLIVEIRA, 2005, p. 48).

As cadeiras representam um status, uma condição que ele almeja ocupar e ser reconhecido por isso, sem que as pessoas olhem para seu passado. O caixeiro visa, então, assumir a posição de Cardoso, o gerente do armazém, que "já não distingue uma farinha de primeira duma farinha de segunda" (Ibid., p. 49) e tem problemas no coração. Seu plano resumese nesta ideia: "Com o coração escangalhado, o que ele anda a pedir sei eu: um susto, que o meta na cama de pés para a cova. E isso arranja-se. Arranja-se e é a gerência, garantida, numa bandeja. A verdadeira entrada aqui" (Ibid.). 
O jogo de cartas - seja pelo hábito, seja pelo vício - representa, nessa obra, uma alegoria da sociedade, imagem que se torna mais evidente pelo pensamento pequenoburguês de Marciano. Em torno do baralho, organizam-se os jogadores, cujos objetivos individuais são obtidos por meio de transgressões às regras - a trapaça. Ora, como um "microcosmo" lúdico da vida, na expressão de Santilli (1979, p. 156), esses homens - que representam o pensamento egoísta e individualista da sociedade burguesa - enganam-se uns contra os outros ou utilizam-se da trapaça alheia para ter algum benefício, como o espanhol Pablo Flórez faz com o Delegado. A vitória nas cartas é a imagem da posição de poder na sociedade, e a busca por ganhar é uma representação do desejo de poder dentro desse contexto. Ludicamente, vemos indivíduos motivados por seus próprios interesses a burlar as regras para obter o que anseiam, custe o que custar.

De fato, Marciano ilustra esse pensamento ao pôr em prática seu plano. No capítulo XIX, Cardoso recebe uma carta anônima, escrita em papel rosa, expondo que sua filha teria feito algo de vergonhoso, levando o coração dele a falhar. Em sua cabeça, transitam diferentes problemas alternadamente: a filha, a carta e os ratos do armazém. Posteriormente, em seu quarto de pensão, Marciano repensa na ação executada para obter a gerência, divagando sobre o momento em que finalmente conseguiria sentar nas cadeiras de couro verde ao mesmo nível que o Delegado, que outrora o humilhou. Fica a especular sobre o que fez e sobre o que deseja enquanto desce, impaciente e sem apetite, à sala de jantar da pensão, de onde se sente o pesado calor e o vento do mar que se arrasta.

Tal personagem representa a visão de Carlos de Oliveira sobre o pensamento pequeno-burguês e a concepção de status. É uma ideia relativa ao poder que o dinheiro exerce tanto para os mais favorecidos como para os menos abastados. No enredo, esse domínio mistura-se à noção de posse e à posição social que se detém neste quadro. Nas palavras de Torres, Pequenos Burgueses é uma reconstituição do meio burguês da Gândara: "os pequenos e baixos interesses do dinheiro que, como mão gigantesca, fazem mover, por cordelinhos, todas as personagens do romance" (1967, p. 259).

Sobre essa citação de Torres, é preciso dar uma explicação: com a reescrita do romance, nem todas as personagens podem ser encaixadas exatamente em tal visão. E, com a revisão, podemos verificar em Pequenos Burgueses também uma certa polarização de classes. Raimundo e Mestre Horácio são exceções dentro do pensamento individualista e interesseiro do grupo no qual estão inseridos. Primeiramente, observa-se que o ferrador é conhecido não por enganos ou trapaças, e sim por seu ofício, pois "realiza com amor e competência a sua atividade" e "concilia bem esse mundo do trabalho com uma atividade 
‘artística"” (DUARTE, 1998, p. 96), pois é um exímio contador de histórias. Em seguida, temos Raimundo, cuja trajetória gira em torno da sua ideia fixa por uma mula. O papel social assumido por tais personagens oferece subsídios para que o leitor depreenda a polarização entre camadas sociais na obra.

Mestre Horácio apresenta-se como um narrador intradiegético, como verifica Lélia Duarte (1998, p. 97), tecendo micro-histórias paralelas às narrativas extradiegéticas. Estabelece-se, assim, dois níveis no enredo: aquele de histórias contadas pelo narrador externo, em cuja voz mistura-se o pensamento das personagens pelo discurso indireto livre, e aquele que traz os contos narrados pelo famoso ferrador. Sua função como contador não tem “objetivos pragmáticos” (Ibid.), mas, por meio dela, o leitor tem contato com informações ligadas ao mundo da elite e ao mundo mais popular. Ora, essa personagem comunica aos seus interlocutores - presentificados por Raimundo - os detalhes que organizam o contexto social rural gandarês, servindo "para retratar a hipocrisia e a luta pelo poder que caracterizam os 'pequenos burgueses' [...]" (Ibid.).

Em oposição aos outros indivíduos do romance, Mestre Horácio transmite certa credulidade, ainda que algumas de suas histórias contenham um aspecto do misterioso. Podemos verificar tal ideia na passagem relatada para Raimundo sobre o almocreve que ficou lesado após uma grande chuva e, após um contato sobrenatural, tornou-se o bruxo dos Moirões. O que se conta tem uma perspectiva de lenda popular, porém o homem coxo, ansiando desesperadamente por uma montaria, vai em busca do bruxo para pedirlhe o animal pensando "Nunca o Mestre Horácio contou nada tão importante como a história do bruxo dos Moirões e note-se que tudo quanto sai daquela boca é importante" (OLIVEIRA, 2005, p. 88).

Desse modo, esse narrador interno à trama tem um caráter de credibilidade diante de seus interlocutores, o que se estende ao próprio leitor e contrasta com o caráter enganador das outras personagens. Ele nos informa sobre os mecanismos em torno das tramas envolvendo a camada alta daquela elite, como a história da mula doente vendida por D. Álvaro. A fama de enganador do comerciante de montarias é, por um lado, reconhecida por ele mesmo nos seus pensamentos e, por outro, na fala popular, traduzida nos relatos do famoso ferrador. O narrador interno, assim, comunica-nos elementos da realidade daqueles habitantes, mostrando-se como conhecedor das relações que pautam essa comunidade.

Essa estratégia permite que o narrador externo se distancie de um caráter pedagógico ou dogmático - retomando as expressões de Duarte e Santilli - pois ele não 
se coloca como "detentor da verdade" ou de uma moral que condene as personagens individualistas. Mestre Horácio tampouco tem essa característica - ele se coloca de forma neutra expressando aquilo que vê, ouve e conhece, isto é, elementos do seu cotidiano. Ele é um contador de histórias, não um moralizador, pois "não pretende [...] dar lições e apresentar soluções, de forma direta" (DUARTE, 1998, p. 97). O narrador interno unido ao externo e ao discurso indireto livre utilizados garantem ao autor "um distanciamento do real para que se possa fazer arte, cuja característica principal é a essência fictícia" (Ibid.). Tal distância, por sua vez, pode ser lida como mais um elemento que desviaria Carlos de Oliveira da estética ortodoxa neorrealista, talvez pelo fato de explicitar que aquilo que narra não está tão colado ao real, dando-lhe uma notável grandeza no que tange ao fazer literário em comparação com alguns colegas do movimento.

A questão do desvio, vista negativamente por alguns críticos, segundo Mário Dionísio (In: OLIVEIRA, 1964, p. 10), seria fruto dos "mil censores" do Neorrealismo os quais afirmam uma doutrina ortodoxa a um movimento que não se pretendera ser escola literária nem oferecer um dogmatismo estético, e a trajetória artística de Oliveira desmentiria exatamente tal equívoco. Estamos diante de um escritor que se vale de artifícios para a sua narrativa, mas o distanciamento do narrador externo de Pequenos Burgueses não significa o distanciamento do autor do seu "conceito de real", na expressão de Dionísio (Ibid., 1964, p. 18), isto é, o seu contato com a realidade em que está inscrito. As tramas que se conectam e se torcem simultaneamente nesse romance constroem a percepção de mundo em que as relações se pautam pelo interesse e pelas ambições individuais.

Em tal cenário surge Raimundo e sua ideia fixa nunca realizada. Ele, um leitor "profissional" de pegadas e sinas, não consegue concretizar aquilo que mais anseia: ter sua montaria. Diferentemente do que ocorre com o Major, por exemplo, cujo desejo de posse se confunde com a preocupação em se manter, de certa forma, no poder, o homem coxo tem um desejo que se confunde com uma necessidade; por sua deficiência, ele reconhece que precisa de um animal que lhe possibilite o deslocamento de aldeia em aldeia, de feira em feira, locais onde pode exercer sua função de ler o destino das pessoas. Temos, então, uma ironia: ele pode ler qualquer sina, qualquer rastro no chão, mas não consegue prever se um dia vai ter o que tanto espera.

A capacidade de decifrar o mundo de Raimundo contrasta com a sua percepção da própria realidade. Sua filha o ignora, trata-o por "seu bêbado" (OLIVEIRA, 2005, p. 17), esperando somente que ele acenda o lume e coloque água para ferver. Seu desejo 
serve de provocação para Troncho ${ }^{70}$, um conhecido ladrão, o que os leva a brigar dentro da taberna do Galo. De certo modo, Raimundo - que lida com elementos da realidade concreta, como os rastros e pegada no chão e as mãos das pessoas - vive alheio em seu próprio sonho. Essa situação é ilustrada por uma cena no início do romance, ainda no capítulo I, na qual o homem coxo põe-se a dormir ao lado da estrada e é acordado pelo galope intenso da égua do Major, montada “à rédea solta, bem apertada nos joelhos”. Ele pensa "quem ma dera a mim" (OLIVEIRA, 2005, p. 10), como nos revela o discurso indireto livre. Naquele momento, ele se encontra literalmente à margem da estrada por onde a égua passa. Mas tal imagem representa metaforicamente a posição de Raimundo diante da realidade: ele é marginalizado.

Esse aspecto também pode ser lido no fato dessa personagem ser manca, conforme analisa Benjamin Abdala Júnior:

\begin{abstract}
Raimundo [...] tinha uma perna coxa, condição física correlata à sua situação psicossocial. Mancava na estória e na história. Caminhava com as pernas na estória, a válida e a outra. Faltava-lhe a integralidade de ambas as pernas, pois simbolicamente uma delas mancava, alienada que fora pela história. E assim, embora fosse adivinhador por dever de ofício, não consegue colocar nas mãos os traços da história que descortina nas pegadas do chão. (2003, p. 184)
\end{abstract}

Nesse sentido, a situação claudicante de Raimundo, assim como Lobisomem de Casa na Duna, representa uma condição alijada diante da história, estando nesse contexto de forma não integral, de maneira incompleta, parcialmente inscrito na realidade em que vive, o que reitera a condição de alheamento em que se encontra. Tal aspecto aproxima a leitura das personagens inseridas na classe trabalhadora de ambos os romances. Assim como percebemos no homem da mula e em Palmira, Firmino e Lobisomem também podem ser vistos na mesma situação.

Lobisomem é visto, na época em que ainda era um funcionário ativo, pelo valor de sua força de trabalho, o que era frequentemente exaltado pelo velho Paulo: “- Um toiro, caramba! Olhem para ele!”. Os comerciantes respondiam: “- Sim, senhor, é uma besta de força” (OLIVEIRA, 2004a, p.10). Antes do acidente, é um empregado valorizado pela sua eficácia, o que podemos ler na metáfora com o touro. Ainda assim, é visto pelos comerciantes como "besta de força", termo que revela a questão física, mas também

\footnotetext{
70 A personagem Troncho aparece no romance Alcateia (1944) como parte da quadrilha de ladrões protagonistas da trama.
} 
sugere uma leitura animalizante e inferiorizante, como um ser que conjuga ao seu vigor uma falta de inteligência.

Quando sofre o acidente em que perde a mobilidade de sua perna, Lobisomem torna-se um peso, elemento concretizado na própria dificuldade de locomoção pelo membro quase morto. O desastre é visto pelo dono da quinta como uma desgraça, afinal é a perda do valor de trabalho desse homem, como observa Gonçalo Duarte (2008, p. 55). O seu valor é bem especificado na quinta: equivale ao seu vigor físico. Perdendo este, seu valor como indivíduo também é perdido. Ele, que vende de alguma forma ${ }^{71}$ sua força de trabalho, já não tem mais o que oferecer após o ocorrido, o que o leva a perder o seu lugar dentro da estrutura social da quinta. Apesar disso, lembra-se com brios dos tempos em que recebia elogios do antigo patrão:

Carros com pesadas dornas a tentar subir a rampa e o velho Paulo a chamá-lo: - Dá uma ajuda a esses bois. Não atam nem desatam. Fincava o ombro na traseira do carro e quase ao rés da terra suportava dornas, tudo, nos ossos de pedra; os bois, aguilhoados, galgavam a rampa. Erguia-se suado, limpava o pó dos joelhos. O velho Paulo sorria e ele ficava à espera do elogio: - Toiros, ao pé de ti, são ratos. (OLIVEIRA, 2004a, p. 31)

A valorização da personagem é medida estritamente pela sua força de trabalho inclusive para si próprio, afinal agora anda tão lentamente que os carros de bois, que outrora desatava, já lhe ultrapassam com imensa facilidade. É um agregado, não mais um “toiro". As suas necessidades enquanto homem não são consideradas, afinal sua existência se confirmava quando desempenhava seu papel físico de trabalhador. Como observa Marx, "as carências do trabalhador são, assim para ela [a economia], apenas a necessidade (Bedürfnis) de conservá-lo durante o trabalho, a fim de que a raça de trabalhadores não desapareça” (2004, p. 92). É nesta chave que é dada a valorização desse funcionário. Isso, porém, incute a ele orgulho pelo reconhecimento. Mesmo que esse vigor seja animalizado aos olhos do empregador, Lobisomem - cujo nome já é indicativo de sua figura meio humana, meio animal - deseja ser reconhecido, estando alheio a esse aspecto inferiorizado do seu trabalho braçal.

\footnotetext{
${ }^{71}$ Em Casa na Duna, não temos informações sobre como Lobisomem era remunerado na época em que trabalhava ativamente. Como o contexto em que se insere a quinta é indeterminado, podemos considerar que esse empregado poderia receber um salário, assim como os jornaleiros, como poderia também trabalhar em troca de moradia e alimentação, algo comum em propriedades rurais anteriores à intensificação do modo capitalista de trabalho.
} 
A animalização, nessa perspectiva, revela uma aguda crítica de Oliveira relativa ao modo como a personagem é vista - reduzida somente à sua atuação como força de trabalho. Esse recurso, constante na literatura neorrealista, expõe o indivíduo em uma categoria de extrema subjugação a ponto de distanciar-se daquilo que o configura como homem, a razão. Ao zoomorfizar Lobisomem, o autor revela a força do poder de seu patrão, o velho Paulo, que vê em seu empregado não um homem, mas uma força descomunal extremamente interessante ao seu negócio. É uma áspera crítica à visão do empregador sobre seu funcionário, visto de forma reduzida e redutora como um instrumento de trabalho, uma coisa, um animal. A força de Lobisomem o equipara aos animais da quinta que lavram a terra. É a mesma força. Há bestas de carga e bois que trabalham na terra e em tal quadro o sujeito Lobisomem não aparece por sua humanidade, e sim por seu caráter animalizante do vigor físico. É, portanto, uma separação entre a razão - atribuída ao ser humano - e a força excepcional - traço de um animal, de uma besta. O elogio do velho Paulo não é à pessoa Lobisomem, mas ao seu caráter de besta humana, muito produtivo e eficiente para a atividade de uma fazenda. Ele é, assim, visto como inferiorizado e subjugado pelo seu patrão, algo contundentemente criticado por Oliveira.

Nesse contexto, a personagem conjuga o seu reconhecimento na esfera social da quinta especificamente como força de trabalho por parte de seu empregador, dos comerciantes e de si mesmo. A sua incapacidade ativa é uma perda do seu valor como indivíduo, uma vez que é visto somente por sua função. $\mathrm{O}$ recurso da animalização nos indica uma diferença marcante entre o Lobisomem ativo e o manco. Anteriormente elogiado pelo seu vigor, era chamado de "toiro", um animal que evoca a ideia de potência. ${ }^{72}$ Tal característica, no entanto, aparece próxima à expressão "besta de força", indicando um aspecto mais inferiorizante ligado à ignorância atribuída à noção de "besta". Após seu acidente, Lobisomem aparece ligado a ideia de sujeira, como ocorre no capítulo VIII, quando ele se dirige à casa dos Paulos para almoçar e a empregada, Maria dos Anjos, diz-lhe: “- Esfregue essas ventas. Pegue numa telha, em sal, e raspe como se faz aos porcos" (OLIVEIRA, 2004a, p. 32). O meio homem, meio touro ou meio lobo reduz-se à repugnância atribuída geralmente aos porcos. De carregador pujante, transforma-se em um agregado tolerado pelo seu passado.

\footnotetext{
${ }^{72}$ Conforme Jean Chevallier (1986, p. 1001) explica, o touro também tem um aspecto ligado à criação, à virilidade e a sensualidade, mas não é possível fazer tal leitura a partir da personagem de Lobisomem em Casa na Duna.
} 
Na construção dessa figura, assim como observamos em Palmira e em Raimundo, Carlos de Oliveira parece criar uma situação de alheamento da personagem em relação à sua condição no cenário gandarês e, mais particularmente, na estrutura social reproduzida nesse contexto. ${ }^{73}$ Palmira, por um lado, abandonou sua atividade que lhe dava certa garantia na casa do patrão pelo seu desejo de casar e ter uma família, aceitando "sem custo", como diz o narrador, sua nova função como nora e como pequena agricultora. $\mathrm{O}$ insucesso do casal na sua plantação parece contrastar com a satisfação da ex-empregada de ter alçado o estado civil de casada.

Raimundo, por sua vez, mistura sonho e realidade no seu desejo fixo por uma montaria. No seu ofício de adivinhador, lida com elementos concretos, como as pegadas no chão de terra, e com traços mais subjetivos, como a leitura das linhas das mãos; na sua existência, ele se encontra entre o real e o imaginário: sobrevive com o peso de sua perna morta e a dificuldade de locomoção, mas alimenta-se de seus delírios de posse de uma mula. Nesse quadro, essa personagem alheia-se de sua condição real de despossuído e relegado - seja pela filha, seja pela própria sociedade em que se insere. Apesar disso, seu desejo de possuir um animal mescla-se entre o sonho e a necessidade real, dada a sua situação física.

Há um dado importante a se considerar em tal contexto: na primeira edição de Pequenos Burgueses, Raimundo, nutrindo o anseio por uma alimária, aceita participar de negócios ilícitos executados pelo Major. Conseguiria, então, comprar uma égua do Major, a qual fora usada anteriormente por este para enganar D. Álvaro. Assim, o comerciante de cavalos e o Major teriam se ludibriado mutuamente e, ao fim, o animal em questão satisfaria o sonho do adivinhador coxo. No término da narrativa, Raimundo é enganado pela própria filha, que foge com um ourives no lombo da tão esperada montaria. Ainda assim, seu desejo é da ordem da necessidade, o que contrasta com os anseios de personagens mais poderosas, como o Major e o Delegado.

Ora, ao suprimir a realização do desejo de Raimundo, Carlos de Oliveira promove uma mudança essencial no âmbito crítico de seu romance. Se considerarmos a primeira edição, Raimundo - ainda que seja pobre e despossuído - equipara-se às personagens da elite no que se refere à ideia de praticar qualquer ação para a obtenção de seus interesses. Desse modo, a crítica recai, de um lado, nos escrúpulos da classe dominante e, por outro,

\footnotetext{
${ }^{73}$ Essa ideia pode se aproximar de alguns aspectos do conceito de alienação, um dos termos considerados centrais para o pensamento marxista e para a filosofia. Porém, no momento, estamos estudando de que modo podemos aproximar o conceito trabalhado por Marx do quadro elaborado por Carlos de Oliveira em ambos os romances.
} 
no desejo da camada mais baixa de alcançá-la. Portanto, a falta de ética não seria algo apenas dos pequenos-burgueses, e sim algo do próprio indivíduo na busca de realização pessoal.

Com a revisão da obra, o autor passa a dar mais foco ao conflito entre as classes. O grupo mais favorecido aparece ligado à falta de moralidade e à ambição inescrupulosa centradas em interesses pessoais, como se observa na figura do Major, do Delegado e de D. Álvaro. O grupo menos favorecido é heterogêneo, por isso torna-se complexo afirmar que há uma dicotomia no livro. Há a personagem de Marciano, que é assalariada, mas expressa-se como ambiciosa e mau caráter; há Mestre Horácio, reconhecido pelo seu ofício rigoroso, transmitindo confiança e sabedoria. Temos ainda Raimundo, que aparenta ser o mais desfavorecido entre eles e não consegue obter aquilo de que necessita ou anseia. Ele aparece como relegado e despossuído em um aspecto mais amplo: de condições adequadas de vivência e de realizações pessoais, ou, utilizando-nos da expressão de Dr. Seabra, "doutras aspirações": "de alegria, de felicidade, dum destino digno" (OLIVEIRA, 2004a, p. 73).

Nesse contexto, tanto em Casa na Duna como em Pequenos Burgueses, temos personagens que estão alheias de sua condição real dentro de uma sociedade de classes pautada na divisão do trabalho. São figuras cuja privação se dá de modo complexo, pois não conseguem modificar sua realidade pela força de seu trabalho e, socialmente, estão inseridas em um contexto que não lhes dá voz para estabelecerem-se por sua autonomia, expondo suas necessidades. Pertencem, à luz do conceito de Antonio Gramsci, à classe subalterna, ou seja, uma categoria social heterogênea em sua formação, mas homogênea em seu caráter alijado de poder, conforme analisa Gayatri Spivak (2010). Esse grupo não se refere a qualquer sujeito marginalizado, e sim àqueles cuja voz não pode ser ouvida. Ao referir-se ao termo "subalterno", Spivak procura descrever "as camadas mais baixas da sociedade constituídas pelos modos específicos de exclusão dos mercados, da representação política e legal, e da possibilidade de se tornarem membros plenos no estrato social dominante". ${ }^{74}$

Nesse âmbito, parece-nos muito significativo o fato de Carlos de Oliveira não trazer a crítica social pela voz dos desfavorecidos ou ainda centrar o desenvolvimento da história estritamente em torno da camada trabalhadora ou "de um submundo de famintos", na expressão de Torres (1967, p. 249). Esse “desvio" do autor, como muitos críticos do

\footnotetext{
${ }^{74} \mathrm{O}$ excerto é traduzido por Sandra Regina Goulart de Almeida e está presente no prefácio do livro Pode o Subalterno Falar? (2010, p. 12).
} 
Neorrealismo apontaram, levou à leitura de que suas obras não expressavam objetivamente uma preocupação com questões sociais. Porém, diante de uma análise das relações socioeconômicas estabelecidas em Casa na Duna e em Pequenos Burgueses, podemos perceber que tais opiniões não se consolidam, pois o que aparentemente está em jogo nessas obras é uma visão mais ampla de como as classes - pautadas no domínio da elite rural - associam-se no cenário gandarês e quais as consequências para os grupos menos favorecidos, oferecendo-nos um olhar sobre a exploração e a subjugação.

A partir de tal ideia, parece-nos equivocada a crítica sobre o desvio pautada exatamente nesse traço, algo que já fora observado por Mário Dionísio em seu prefácio à terceira edição de Casa na Duna. Ele nos diz:

Porque o que, sem dúvida, separa o realista de todos os antirrealistas não é o reconhecimento, ou não, do clima angustioso que uns e outros respiram e nenhuma teoria poderia deixar de fazê-los respirar, mas a convicção, para uns, de que tal clima é o clima normal da natureza humana e, para outros, um clima provocado por circunstâncias históricas determinadas ou determináveis, apesar da extrema complexidade de que se revestem [...] (In: OLIVEIRA, 1964, p. 16-17).

Carlos de Oliveira estaria, para ele, certamente entre o segundo grupo, pois sua obra está inscrita dentro de uma estrutura ampla, pautada pelo poder e pelo capital, determinante da condição de vida dos homens, sendo definida por quadros históricos mais complexos.

Casa na Duna mostra-nos exatamente como o cenário da quinta de Corrocovo está inserido em circunstâncias históricas determinantes e determináveis; o colapso da estrutura construída e mantida por gerações da família Paulo define e é definido. Dentro dessa relação, o autor nos propõe a pensar as consequências de miséria e carência das classes mais pobres. Os trabalhadores estão à mercê da incapacidade de Mariano Paulo de fazer uma reconversão da posição social de sua família e de sua propriedade, isto é, de se adaptar às novas estruturas que o capitalismo industrial e o progresso da infraestrutura trouxeram para, então, manter-se no poder socioeconômico preservado por gerações. Na queda da família, expõe-se a situação de precariedade na qual os trabalhadores ligados a ela permanecem como "há mil anos", dando continuidade à exploração e à ordem tida como natural naquele ambiente.

A reescrita de Pequenos Burgueses, por sua vez, indica também uma estrutura socioeconômica pautada nas relações de poder. É nos meandros dela que se deve pensar a condição dos menos favorecidos como Raimundo. Nessa obra, não há o colapso de uma elite, e sim o foco nas motivações desse grupo ao buscarem manter seu poder. Oliveira 
nos mostra como os interesses individuais e egocêntricos pautam o modo como a comunidade de Fonterrada se organiza. São postos em questionamento os escrúpulos e a ética de personagens inseridas em uma circunstância histórica que privilegia o poder e o capital. Surge, por oposição, a figura de Raimundo, leitor de mãos e rastros que não consegue concretizar o seu maior anseio - sendo também sua maior necessidade.

Parece-nos, nesse contexto, um equívoco afirmar que Carlos de Oliveira se centrou estritamente em torno da elite, uma vez que ele mostra uma compreensão ampla do quadro que se propôs averiguar. Classes dominantes pressupõem classes dominadas dentro de uma concepção histórica da sociedade, e isso é elaborado a partir da perspectiva do colapso de Mariano Paulo e o modo de organização de Corrocovo e da estrutura social de Fonterrada. Personagens como Lobisomem, Palmira e Raimundo inserem o leitor em um lugar mais próximo às classes desfavorecidas. E, ainda que eles não expressem um posicionamento crítico sobre o cenário de exploração e precariedade no qual vivem, o leitor torna-se a peça que organiza as informações em benefício da tomada de consciência e da necessidade de superar tal desigualdade, ideia importante ao movimento neorrealista.

Embora não exprima a conscientização na voz da classe subalterna, o autor da "Tetralogia da Gândara" permite que seus leitores se aproximem muito objetivamente das demandas dela, incitando a sua crítica ao modelo socioeconômico rural português. Em tal âmbito, podemos pensar de que modo o autor representou o grupo em seus romances, considerando seu suposto distanciamento do escopo primordial do grupo neorrealista. Como vimos, afirmar somente a centralidade da elite e da pequena-burguesia nos enredos pode nos levar a uma leitura errônea deles. O que parece se configurar nas obras analisadas é uma problematização da ideia de representação feita por meio das personagens desfavorecidas.

Primeiramente, se considerarmos o campo social, observa-se que Carlos de Oliveira não insere um narrador-personagem em $1^{a}$ pessoa que comunica ele próprio a sua condição de precariedade. A exploração e a miséria vivenciadas não aparecem explicitamente de forma consciente nas personagens empobrecidas, o que pode ser lido como alheamento delas diante de suas próprias condições de existência. Na trajetória de Raimundo e Palmira, por exemplo, observamos justamente uma "não voz", pois, ludibriados pelos seus anseios, a vivência de miséria não é denunciada objetivamente por eles, estando alheios, de certa forma, da sua própria voz. Em Casa na Duna, temos uma personagem que fala sobre a condição dos trabalhadores, porém comunica pelas consequências dessa situação, ou seja, como médico, Dr. Seabra lida com o que a miséria 
causa a esses camponeses. Ele constata e analisa, e não se coloca no lugar deles ou fala por eles. As posições, assim, mantêm-se, expressando que o subalterno continua sem voz.

Em Pequenos Burgueses, Raimundo está no lugar de ouvinte: ele é o interlocutor por excelência de Mestre Horácio, o qual conta histórias retratando o fingimento da outra classe. Como locutor, o homem das mulas não consegue se estabelecer totalmente, afinal é, de certa forma, relegado, inclusive pela própria filha. E na ideia fixa de obter uma montaria, ele "não vê as raízes do chão sociológico" que o envolvem (ABDALA JR., 2007, p. 242). Quem enxerga a carência de tal personagem é o leitor, afinal este é o interlocutor das vozes que se articulam em torno da pequena-burguesia de Fonterrada. Raimundo decifra a história de outros, mas não a sua própria.

No plano literário, entretanto, Raimundo e Palmira estabelecem-se de certo modo a partir da expressão de sua subjetividade que reside nos almejos de cada um. Se, socialmente, considerarmos que o leitor de rastros, por exemplo, não consegue estabelecer sua voz por estar em posição marginal no cenário gandarês, ele expressa ainda que subjetivamente - sua voz na narrativa, por meio do seu sonho de obter uma montaria. Esse desejo é um modo de Raimundo nos dizer quem é e o que pensa. Da mesma maneira, temos Palmira. Através de seu anseio pelo casamento, conseguimos compreender a personagem. Identificamos socialmente seu alheamento diante de sua posição social, mas conhecemos sua individualidade por meio daquilo que seu sonho expressa.

O autor, assim, oferece-nos uma dupla visão da classe desfavorecida. Por um lado, há um silenciamento causado socialmente pelas condições de precariedade e de exploração em que tal camada vive. Naturalmente, Carlos de Oliveira apresenta personagens representando-as, mas propõe-se a pensar nesse espaço em que o subalterno não tem totalmente voz ao construir o cenário que tanto o marcou na infância. Ele, assim, traz a Gândara e as suas personagens subalternas através da própria condição delas, moradores de "casas de adobo" que são convertidos em "figuras sacrificiais", como observa Viçoso (2011, p. 161), mas que são silenciadas na complexa teia de relações sociais estabelecidas pelo poder e pelo capital da elite rural. $\mathrm{O}$ autor nos oferece um quadro feito da "realidade que o cerca", como afirma em "Almanaque Literário" (2004b, p. 65), e sua mensagem constrói-se parcialmente por esse silêncio, pelos anseios jamais realizados e pela miséria não superada, presentificando o alheamento dessas personagens diante da própria trajetória ao transcrevê-lo “em termos literários”, como afirma (Ibid.). 
Nesse silêncio, permite que o leitor veja e compreenda a posição de subjugação, inferioridade e privação que envolve os camponeses.

Por outro lado, esse silenciamento observado no campo social não é total se considerarmos a esfera literária. As personagens "falam" - ainda que por meio de seus pensamentos - através de seus sonhos. Sim, sabemos que tais desejos não são necessariamente satisfeitos, como no caso de Raimundo, mas relevam na narrativa a voz dessas pessoas. Por meio da subjetividade, cria-se no enunciado uma voz para esse grupo, o que torna o silêncio imputado pela exploração e pela privação "de quase tudo" algo não totalizante. Desse modo, temos na esfera social o alheamento e a não voz de um setor à margem da sociedade, porém, individualmente, temos o desejo e o sonho, que dão voz a essas personagens na esfera literária. Esse contraste permite que o leitor desenvolva uma reflexão sobre as consequências da subjugação e da pobreza advindas das relações sociais de poder e oferece, a essa camada, uma espécie de posicionamento - ainda que na narrativa -, um lugar que historicamente lhes é negado.

Assim, o "desvio" de Carlos de Oliveira diante do Neorrealismo expressa-se na grandeza formal ao trazer a temática social de forma complexificada, indicando de que modo a camada desfavorecida configura-se diante das relações sociais estabelecidas na zona rural gandaresa e dando-lhe um lugar em um cenário que os marginaliza e os subjuga. Expõe a realidade aos olhos do leitor, contando com este para articular os elementos do quadro social e, então, decifrá-lo. Ele reconhece que, como escritor, não precisa apresentar soluções, pois confia na capacidade crítica da leitura na compreensão do mundo real. Afinal, segundo diz, "A realidade cria em si mesma os germes da transformação; o processo consiste sobretudo em captá-los e desenvolvê-los num sentido autenticamente moderno" (Ibid.). Portanto, pela leitura, nós rasgamos o véu das aparências, como indica o narrador de Pequenos Burgueses: “A importância do véu reside exactamente no facto de ser preciso rasgá-lo para se ver melhor” (OLIVEIRA, 2005, p. 127). Nas teias sociais da Gândara, o leitor rasga o véu das aparências, do capital e do poder para ver melhor a exploração e a miséria que habitam esse cenário. 


\section{Finisterra}

Em seu ensaio "Almanaque Literário", Carlos de Oliveira afirma que o ofício do escritor "consiste em escolher as palavras, utilizá-las no momento exacto, atenuá-las, engrandecê-las, dominá-las" (2004b, p. 62). Ora, tal domínio, complexo e agudo, talvez tenha sido levado a uma alta potência se considerarmos a grandeza de seu último romance, Finisterra: paisagem e povoamento, cuja primeira publicação data de 1978. Em um exímio exercício de forjar sentidos e significados, esse livro apresenta-se como uma escrita de equilíbrio entre o narrativo e o poético, como observa Maria Lúcia Lepecki (1988, p. 53). Demonstrando conhecer "até ao pormenor a matéria de que se serve" (OLIVEIRA, 2004b, p. 62), isto é, a palavra, o autor "lança-se no campo da polissemia" (LEPECKI, 1988, p. 51), envolvendo o leitor em uma teia de metáforas, sinédoques e, claro, de representações que sempre apontam para o poder da linguagem no fazer literário.

Esse romance traz, em sua "Nota Final" - uma espécie de metatexto -, o processo que levou à sua gênese:

Imitando um dos narradores deste livro (coincidência e necessidade), também o autor coligiu numa única pasta velhos papéis dispersos: alguns, dactilografados; outros, manuscritos e às vezes (quase) ilegíveis. Decifrou a letra emaranhada, reconstituiu lacunas, ordenou tudo pelas diferenças caligráficas, a cor da tinta, os caracteres (mais ou menos nítidos) da máquina: sinais dum trabalho intermitente. Em seguida (clarificado o material), nova ordenação, cortes, e acabamentos necessários (aliás, muito breves). (OLIVEIRA, 2003, p. 141)

Em uma alternância entre alerta e explicação, Oliveira ainda faz a ressalva ao leitor: "Aqui está o romance (um dos romances) escrito e anunciado há anos, sem a garantia de terem aparecido todos os papéis" (Ibid.). Mesmo em sua origem, Finisterra resguarda e reitera seu caráter polissêmico, múltiplo: é um dos romances que poderia ter nascido desse longo e, provavelmente, exaustivo mecanismo da revisão e ordenação atenta.

Apesar de ser uma nota no fim da obra, tal metatexto nos indica um dos elementos essenciais da narrativa poética: as múltiplas vozes que a tecem. Se observarmos a citação acima, vemos que Oliveira desdobra-se: “[...] o autor coligiu numa única pasta [...]". Referindo-se a si mesmo em $3^{\mathrm{a}}$ pessoa, ele inverte a ordem genética ao atribuir a origem primeira a um dos narradores, como verifica Manuel Gusmão (2009, p. 21) e, ao desdobrar-se, coloca-se ao mesmo tempo dentro e fora do romance, antes e depois. Finisterra seria uma obra multíplice, em que o tempo se alterna entre presente e passado a partir de diversas memórias; o espaço configura-se em numerosas e obsessivas 
representações da paisagem, oferecendo ao leitor um romance também de interpretações múltiplas.

As diferentes vozes que tecem o discurso dessa obra anunciam uma temática sobre a qual os leitores de Carlos de Oliveira já tiveram a oportunidade de ler: a decadência de uma família e de sua propriedade na arenosa paisagem das dunas. É impossível que nossa memória não nos remeta ao declínio da família Paulo, cujo fim é metaforizado através do incêndio da grande casa familiar em Casa na Duna. Finisterra surge também a partir de um processo de ruína que indica, com a degradação da residência, o fim de uma linhagem e também, como observa Martelo (2000, p. 251), a possível queda de uma classe social.

No último romance, não temos a nomeação da paisagem, como observamos nas narrativas anteriores de Oliveira. O termo Gândara não aparece explicitamente como uma referência espaço-geográfica, no entanto o leitor está novamente diante de um cenário árido, marcado pela orientação que as dunas fazem. Tal ambiente mostra-se instável, afinal os ventos moldam a paisagem a todo momento em que sopram e movimentam os montes de areia, criando novas percepções. No início, encontramos a criança sentada em um osso de baleia, aparentemente desfazendo-se pela ação da erosão. Ela observa a paisagem para então reproduzi-la de cor. O sol incide intensamente sobre esse cenário, sobre a sílica e a mica, reflexos que provocam uma forte luminosidade. A casa é descrita como se estivesse protegida por uma "atmosfera lúcida, quase luminosa" (OLIVEIRA, 2003, p. 10), um halo que a envolve misteriosamente, preservando-a dos elementos externos: "Para lá do halo, o ar é escuro, peso que se move e revolve com lentidão" (Ibid.).

A descrição do ambiente apresenta-se a partir de caracterizações que unem um viés objetivo a uma percepção subjetiva, como o ar, definido como escuro e, ao mesmo tempo, pesado. Essas impressões, porém, não podem ser atribuídas exatamente ao narrador, pois o romance enovela-se pela presença de diferentes narradores como citamos anteriormente. Já no primeiro capítulo, surge, além da criança sentada desenhando na ossada, o homem, que se prepara para criar um esquema espacial da residência, medindoa, cômodo por cômodo, para então poder movimentar-se "altas horas através da casa: às escuras e sem tropeções" (Ibid.). O que se verifica logo nesse trecho é a alternância entre a voz de um suposto narrador e a desse homem que mensura as distâncias e as superfícies da casa.

A caracterização do espaço interno - feita sob o pretexto da medição mental do local - é dada paralelamente à do espaço exterior, cuja representação é uma ideia fixa central do romance elaborada através de diferentes personagens: o pai, a mãe, a criança e 
o homem. Tal paisagem é descrita ao longo de toda a obra, o que ressalta a sua instabilidade e mutabilidade. No capítulo II, a criança aparece dentro de casa, sentada em um balanço de mogno, examinando atentamente o cenário que vê através da janela, o qual divide-se em três zonas: primeiramente, a região da areia, ocupando o terço inferior da imagem enquadrada pela janela. Segue-se por "uma faixa estreita de gramíneas" (OLIVEIRA, 2003, p. 11), onde há uma lagoa que evapora, criando juncos roxos no local. As cores nessa região modificam-se e misturam-se de acordo com a luz do sol e a força do vento, o que é descrito como uma ondulação, e as dunas acompanham tal movimento. Por fim, a terceira faixa, que termina na linha superior da armação de metal da janela, é formada pelas dunas distantes, iluminadas pelo "revérbero da cal" (Ibid., p. 12) e pela luz das estrelas. Há ainda "uma nesga de azul" que pode ser, segundo o narrador, ao mesmo tempo céu e mar, uma "placa de zinco a incendiar-se" ou ainda um "reflexo turvo da luz" (Ibid.). Aos olhos da personagem, é como uma miragem originada pelo brilho luminoso, o que suscita uma perspectiva fantástica à descrição.

A ênfase nessa questão deve-se justamente pelo fato de que ela será obsessivamente perseguida pelas personagens do romance em tentativas de reprodução do que se vê, como abordaremos ainda. Recriar a realidade que se enxerga é fixamente um propósito do núcleo familiar central. O pai, por meio da fotografia, procura representar a imagem que vê através do caixilho da janela. A mãe procura apresentar a paisagem em sua atividade de pirogravura em um almofadão coberto de pele de carneiro. A criança, por sua vez, desenha, a partir de uma percepção muito livre, a paisagem, repovoando-a com os antigos peregrinos que teriam, num tempo passado, habitado tal lugar. $\mathrm{O}$ adulto procura elaborar uma maquete que também recrie o cenário visto. Assim, observamos personagens que se dedicam a construir "modelos de mundo", como nota Martelo (2000, p. 256) e, no desenvolvimento da narrativa, tais tentativas de criação e de apreensão da realidade percebida contrastam com a instabilidade e mutabilidade da natureza em si, totalmente à mercê da força do vento e da luz solar.

À tal ideia fixa, soma-se uma informação central ao enredo: o princípio da indiferenciação que rege as narrativas da obra. A primeira leitura já nos indica que os elementos da paisagem - tão percorridos pelos olhos da família que busca apreendê-los são descritos a partir de um mecanismo crescente de indiscriminação. Uma segunda obsessão, esse pensamento atravessa o romance, conforme observa Luís Mourão (1996, p. 278). Buscaremos aprofundar tal ideia ao longo de nossa análise, pois a questão dialoga com a temática central da decadência familiar. Podemos notar, porém, que, logo no início 
de Finisterra, a paisagem apreendida a partir do caixilho já nos sugere a ideia de que os elementos misturam-se, consubstanciam-se, perdendo seus contornos. O processo de indiferenciar-se é ativo e progride à medida que a propriedade familiar vai se perdendo em seu declínio, o que resulta no trágico fim: a casa - em total decadência - é tomada pela força de assimilação da gisandra: um misterioso elemento também indiferenciado, uma vez que é descrito como algo vivo entre o reino animal, vegetal e mineral. Retomaremos essa ideia no desenvolvimento posterior.

É tal o cenário em que vivem as personagens centrais do romance. O protagonista surge, já adulto, em um constante diálogo com uma criança que um dia viveu naquele local. A leitura que a crítica em geral faz sobre essa dinâmica, com a qual concordamos, é que o homem e a criança são a mesma pessoa. Logo, seria uma conversa entre o homem no tempo presente com o seu passado, suas memórias, personificadas pela criança. Podemos notar algo importante: ele não é nomeado, do mesmo modo que todas as personagens não o são. A identificação de cada um se dá pela função social e familiar de cada membro. Temos, então, o pai e a mãe, a criança/o homem, que é o filho, o tio e o avô, que surge no enredo a partir da rememoração. Há ainda a presença do amigo da família, o qual tem um papel ativo no processo de tentativa de recuperação da propriedade. Contamos também com a presença do executor fiscal, o senhor que vem à residência para cumprir a hipoteca, isto é, tomar a casa e torná-la posse do Estado. Ora, o núcleo central de Finisterra é, portanto, a família, que estabelece o vínculo (obsessivo) com a paisagem e a propriedade, a qual está à mercê de duas ameaças: o poder estatal pela residência hipotecada - e o poder "indiferenciador" da natureza, representado pela força da gisandra, que assimila todos os outros elementos pelo qual se espalha.

Estamos diante de um complexo romance que condensa diferentes narrativas, as quais tecem uma narrativa central que indica uma dupla decadência: a queda de uma família e a perda de uma propriedade, seja pela força da natureza, seja pelo poder do Estado. A esse fio central, juntam-se as obsessões da representação - perseguidas pelas personagens - e da indiferenciação - simbolizadas pela misteriosa gisandra. Há ainda a dialógica dinâmica entre a rememoração e o tempo presente, que ampliam a esfera polifônica e polissêmica da obra, o que a torna uma "alegoria infindável”, nas palavras de Osvaldo Manuel Silvestre (1995, p. 13).

Nesse sentido, propomos uma leitura - e uma indagação - sobre o lugar de Finisterra dentro do percurso neorrealista não ortodoxo de Carlos de Oliveira. De que forma essa obra dialoga com a temática presente nos romances anteriores da "Tetralogia 
da Gândara”, mais especificamente com Casa na Duna e Pequenos Burgueses, objetos da nossa análise no capítulo anterior. Tentaremos estabelecer uma leitura sobre como a questão do declínio familiar e da propriedade configura-se dentro da abordagem de influência marxista que verificamos anteriormente, considerando o exímio trabalho com a linguagem deste último livro que nos coloca diante da movediça fronteira entre prosa e poesia.

\subsection{Entre a poesia, a prosa e a metaficção}

Vinte e cinco anos após a publicação de Uma Abelha na Chuva, Carlos de Oliveira publica sua última obra, que traz, como um segundo subtítulo, a indicação de seu gênero: romance. O primeiro contato com o texto nos coloca diante de uma leitura completamente distinta daquelas promovidas pelos livros anteriores do autor, fazendo-nos questionar justamente a sua classificação como romance. A leitura é perturbadora, como aponta Lepecki (1988, p. 50): como leitores, apreendemos um discurso que problematiza a figura que narra, estabelecendo um limite muito tênue entre um suposto narrador, o aparente protagonista e as diferentes personagens do núcleo familiar inominado. A imagem que a autora usa para ilustrar a leitura de Finisterra é bastante esclarecedora: lemos e, durante o processo, sentimos que corremos o risco de perder o rumo, de não encontrar o centro dessa história amplificada pelas diversas vozes que comunicam suas obsessões, suas memórias e suas preocupações.

Além disso, percebemos o centro da obra em movimento constante quando notamos a potencializadora força poética das palavras que tecem a narrativa. "Tal como ocorre num poema, Finisterra concentra informações em cada palavra", diz Lepecki, cuja leitura aponta para a ideia de que esse texto se configura como uma espécie de gênero intermédio entre a prosa e a poesia, e seu discurso direciona o leitor ao estranhamento diante desse registro "concentrado e difuso" simultaneamente (1988, pp. 50-51). De fato, Finisterra promove um movimento de diluição de certas fronteiras: temos de considerar que é um romance, afinal o autor deixa tal indicação no próprio título, porém o discurso comunicado nos remete à linguagem poética a todo instante, o que nos permite pensá-lo como uma alegoria do fim de uma linhagem familiar e do fim de um sistema social.

Ora, diante de tal problematização, Manuel Gusmão afirma que Finisterra apresenta um caráter duplo: romance e poética autoral como entidades "quase coextensivas, ou profundamente entrelaçadas" (2009, p. 17). A obra seria, então, do princípio ao fim, "a concentrada figuração narrativa de uma poética" (GUSMÃO, 2009, 
p. 17), isto é, uma alegoria que tem como fio condutor o desfecho de uma família e de sua propriedade. Poderia ser ainda, como nos indica Eduardo Lourenço (1984), uma "minuciosa e agônica revisitação espectral e simbólica" daquilo que lemos no primeiro romance do autor, Casa na Duna. É o fim de uma terra - o fim da história de ocupação familiar - na terra do fim, isto é, o fim do mundo espacial-geográfico da paisagem gandaresa, um lugar ainda habitado e "já inabitável”, onde se negocia uma sobrevivência difícil, como analisa Pedro Eiras (2014, p. 119).

Antes de nos adentrarmos pela questão da alegoria do fim de um mundo ocupado por uma família, é importante ponderarmos um aspecto expresso por grande parte da crítica sobre esse romance. Finisterra engendra visivelmente uma ruptura com os moldes das obras da "Tetralogia da Gândara" e, em consequência disso, com o próprio movimento neorrealista. Esse processo não é exclusivo da última obra, mas, sim, algo que acomete o mecanismo de revisão e reescrita elaborado por Oliveira tanto em seus volumes de prosa como na poesia de acordo com os críticos, como Gusmão (2009). A leitura que fizemos de Pequenos Burgueses, por exemplo, já nos indicou tal fato e por isso o lemos a partir do viés do desvio do autor de um Neorrealismo mais ortodoxo.

Em Pequenos Burgueses, na terceira edição, que data de 1970, já havíamos detectado o processo de criação polifônica da narrativa, um movimento que também, muitas vezes, faz-nos sentir perdendo o rumo da leitura, aqui nos aproveitando da expressão de Lepecki sobre Finisterra. Percebemos que, com a reescrita das narrativas dos pequenos burgueses, o leitor fora convocado a participar ativamente do processo de compreensão e construção do sentido da obra. Identificamos pequenas narrativas que se tecem, enovelando-se em torno de Raimundo e sua ideia fixa. Carlos de Oliveira, na reelaboração, já cria uma problematização da noção de narrador multiplicando sua função entre as diferentes personagens. Ao leitor, então, cabe o papel de organizar as várias vozes e os diferentes discursos para produzir uma interpretação da narrativa.

Citamos aqui o processo de reescrita de Pequenos Burgueses por este ser o mais diferenciado na obra ficcional de Oliveira. A propósito desse fato, Manuel Gusmão dedica uma seção de seu livro Finisterra - o trabalho do fim: reCitar a origem (2009), verificando que Finisterra poderia ser visto também como uma reescrita de Pequenos Burgueses. Não compartilhamos exatamente dessa opinião, porém é notável que o mecanismo de revisão deste comporte elementos de transformação da prosa que culminarão naquilo que observamos no último romance, especialmente no que se refere à configuração discursiva e à figuralidade (GUSMÃO, 2009, p. 57). 
O crítico ainda verifica que o desenvolvimento de Finisterra é contemporâneo ao procedimento de reescrita e revisão de algumas obras poéticas de Oliveira, como Turismo, que volta a ser incorporado no conjunto lírico do autor na publicação de Trabalho Poético, de 1976, Sobre o Lado Esquerdo e Micropaisagem, os quais têm reedições em 1969 (2009, p. 54). É nesse sentido que a crítica aponta um movimento de diluição ou distanciamento de Oliveira de uma estética neorrealista e, ao mesmo tempo, uma aproximação da composição de Finisterra com outras obras líricas e ficcionais. Para Gusmão (Ibid., p. 55), “Finisterra, por seu turno, incorpora [...] motivos que figuraram antes na sua poesia [de Carlos de Oliveira], desde Turismo, ou em outros lugares da obra, dos romances a alguns textos de $O$ Aprendiz de Feiticeiro [...]".

Tal análise ajuda-nos a compreender de que modo o último romance provoca uma certa ruptura com os moldes ficcionais apresentados pelos livros anteriores, sobretudo se considerarmos as edições iniciais. Ela aponta também para um mecanismo interessante de composição que o aproxima do trabalho poético de Oliveira. Torna-se mais clara a noção de que Finisterra comporta elementos da obra ficcional e lírica do autor, além de movimentar-se entre os gêneros. Da mesma forma que identificamos uma semelhança inegável entre este livro e Casa na Duna no que diz respeito à temática central, localizamos imagens e figuras comuns a Turismo e a Micropaisagem, por exemplo. Procuraremos indicar tais aproximações incorporando-as ao discurso analítico.

Finisterra coloca-se em um lugar de limite fluido entre a prosa e poesia, o que poderia nos levar a chamá-lo de prosa poética. O autor nos orienta a lê-lo como um romance, classificação que consta na capa do livro. Na sua leitura, encontramos, porém, a figuralidade (expressão de Gusmão) e as imagens que são próprias da poesia de Oliveira. Luc Decaunes, em seu estudo sobre o poema em prosa, procura estabelecer uma diferenciação entre este e a prosa poética, dizendo-nos que

Textos dessa natureza [prosa poética] destacam-se por apresentarem um deslocamento inesperado em relação aos modelos habituais, justamente porque conseguem desenvolver na prosa uma criação dotada de carga poética. São exemplos da prosa levada ao estado da poesia, mas sem abrir mão do plano narrativo - ou extensivo. (1984, p. 16, apud PAIXÃO, 2013, p. 153)

Assim, conseguimos perceber no romance a manutenção de um certo plano narrativo, baseado no enredo de um homem que regressa à casa de sua infância, constrói sua maquete e rememora o seu passado a partir do diálogo com a criança que um dia foi. Entre 
prosa e poesia, o romance se compõe em um constante movimento. Como observa Fernando Paixão,

Os conceitos escorregam entre os dedos, repetem argumentos semelhantes por dizeres diferentes e, na verdade, não permitem desenhar um molde que seja pertinente a todos os textos. Frente a qualquer explicação genérica, sempre será possível apontar exemplos de autores e poemas que escapam ao campo definido. Isso porque, do ponto de vista formal, trata-se de uma escrita em aberto, alimentada por um estado de contradição contínua: poesia e prosa a um só tempo. Oximoro (2013, p. 155).

Há, portanto, dois polos - a prosa e a poesia - que se aproximam dialeticamente, visitamse e complementam-se através das várias vozes que comunicam as narrativas.

Em sua análise, Nuno Júdice verifica que Finisterra é um "dispositivo de escrita fragmentária, em que os segmentos do cenário, do real e do conto se articulam de modo somativo, obrigando a levantá-los à medida que se dispõem nessa sua sequência que não corresponde a uma lógica ficcional obrigatória" (In: SILVESTRE, 2011, p. 15). Há, por um lado, temas, imagens, elementos da natureza e objetos que aparecem de maneira quase arbitrária, mas criam uma "base verbal" que é, por sua vez, o elemento de ligação entre os capítulos, conferindo uma "solidez estrutural à organização" (Ibid.).

A exemplo de tal conexão, podemos identificar a gisandra, um elemento fulcral para compreendermos a existência de um fio condutor narrativo. Sua ação de assimilação de outros materiais ocorre ao longo do enredo de maneira crescente: inicialmente, ela está ocupando-se do jardim da casa, que parece abandonado. No capítulo final, enquanto o homem põe-se a analisar documentos antigos da família e a planta da casa, sabemos que a espécie indiferenciada de animal, de planta e de mineral está tomando a casa:

Vejo (num breve fulgor do halo) a golfada gelatinosa rondando a cadeira de espaldar, onde esteve o executor fiscal (e, a seguir, a mulher dos dois rostos). Nasce no vão da janela (embaixo, junto do rodapé: linha aberta entre duas tábuas podres), espraia-se pelo tapete. Dissolve (primeiro) a cinza que tombou do xaile de merino; e depois (à segunda investida), arrasta os grãos de saliva do executor, que tilintam (e brilham) até desaparecer (OLIVEIRA, 2003, p. 139).

Logo, conseguimos identificar uma base narrativa no romance proporcionada pela base verbal, nas expressões de Júdice, e pelo processo de decadência da casa e sua assimilação pela gisandra, indiferenciando os objetos e os elementos do plano natural. Apreendemos esse processo como um desenvolvimento estrutural do fio narrativo. As imagens de tal indiferenciação nos remetem, ao mesmo tempo, ao universo lírico de Oliveira, pois o 
romance "reenvia a linguagem romanesca do autor para um território em que ela claramente se indiferencia da sua linguagem poética tal qual foi revista pela depuração de Trabalho Poético", segundo a percepção de Luís Mourão (2011, p. 32).

Da mesma maneira como a gisandra se estende pela narrativa formando uma espécie de fio condutor da trama, observamos também o desenho da criança, que aparece sugerido desde o primeiro capítulo e percorre o desenvolvimento do texto. No terceiro capítulo, trecho em que aparece o diálogo entre o homem e a criança através da fala do narrador, descrevem-se elementos do desenho, como seus traços, as cores e as formas que povoam aquela paisagem. O homem questiona a criança sobre as dimensões não reais que aparecem nas formas, como a minúscula lagoa, desenhada somente como uma gota d'água. Na sua resposta, a criança rememora o momento de sua criação, lembrando-se de que sentia sede e de que, naquele momento, a chuva esperada não viera: "quando temos sede, a água parece sempre pouca”, diz o pequeno desenhista (OLIVEIRA, 2003, p. 16).

Em oposição ao tamanho da lagoa, surgem os enormes grãos de areia. Tal dimensão desproporcional é interpretada pela criança como uma ação do vento, que faz os grãos incidirem contra a janela, criando um barulho e uma agitação na casa. O diálogo é retomado no capítulo $\mathrm{V}$, onde o homem questiona a "cabeça de fogo" dos peregrinos. No decorrer do livro, os elementos do desenho voltam a ser retomados, em especial no capítulo XXVIII, cujo cenário e personagens parecem sair justamente dessa representação da paisagem feita pelo menino. Os peregrinos começam a analisar a floresta, discutindo se devem atravessá-la ou não, pois receiam incendiá-la, afinal sustentam cabeças flamejantes. As dimensões do local estão deformadas, assim como ocorre no desenho: "Cada árvore destas mede (calculando por baixo) dez vezes a altura dum sombreiro. Além disso, direitas como torres. E, mesmo a cor, duvidamos" (OLIVEIRA, 2003, p. 116).

Ao mesmo tempo em que hesitam, os peregrinos pensam que o céu avermelhado lembra o inferno. Notam que as aves estão imóveis a sobrevoá-los, o que indica uma referência à imobilidade do desenho. A cena pode ser entendida como a imaginação da criança que, diante da indecisão dos peregrinos, entra na floresta. Eles voltam a ser retomados no capítulo XXXI, no qual é comunicada uma espécie de ritual protagonizado pela mulher nua, talvez a mãe, pois carrega a tatuagem do crucifixo. Como se fossem reais, os homens sentem-se amedrontados e, ao mesmo tempo, tentados pela figura feminina, chegando à conclusão de que aquilo não é algo de Deus. Desse modo, o desenho configura uma estrutura de base no desenvolvimento da narrativa, conectando diferentes 
personagens e elementos que surgem como fragmentos de uma outra narrativa interna, isto é, aquela contada pela paisagem rabiscada pela criança.

Além de estabelecer-se como um objeto condutor do enredo, o desenho infantil também nos remete ao léxico lírico de Carlos de Oliveira, surgindo como uma espécie de eco de imagens ao longo da leitura do romance. A gota da lagoa, por exemplo, faz-nos pensar nos primeiros poemas da reescrita de Turismo. O simples trístico ${ }^{75}$ de abertura da seção "Infância” retoma tal forma: "Terra/ sem uma gota/ de céu” (OLIVEIRA, 2003b, p 09). Segue-se o poema VI, em que o trístico inverte a ordem dos elementos: "Céu/ sem uma gota/ de terra" (Ibid., p. 14). Ambos os poemas parecem sugerir uma imagem ligada à água; no primeiro, está a terra "sem uma gota / de céu”, que podemos ler como referência a nuvem e chuva. A terra está, assim, seca, sem água. O poema seguinte inverte a imagem, agora o céu não tem uma gota de terra, o que pode sugerir a ideia da tempestade, da abundância de água em oposição à secura da terra. Em Finisterra, também temos uma alusão a essa situação no desenho: a chuva esperada não vem ou vem apenas em pequenas gotas. Em contrapartida, temos a referência a trovoadas:

"Têm caído relâmpagos de carbureto nas aldeias?

As trovoadas não param. Raios que matam gente e gado, incendeiam casas, fendem pinhais inteiros. O inferno a mudar-se, com armas e bagagens. É o que dizem nas igrejas" (Idem, 2003a, p. 23).

A relação entre os camponeses - peregrinos -, a água e a paisagem arenosa é também retomada no poema de Pastoral, presente no Trabalho Poético, "Camponeses":

\author{
Porquê? Um tal volume \\ de águas: já \\ nas conchas rochosas; \\ obturando a erosão; \\ se fecham outras fontes, outras \\ arcas antigas. Para abrir \\ depois, saber \\ da chuva numerosa \\ que fulgor perdura; \\ ou grão; \\ mesmo de poucas nuvens. \\ Porque tão perto \\ o vento percutisse \\ todo o percurso disso, \\ melhor será esperar o ar
}

\footnotetext{
75 Este poema estrutura-se a partir de um verso do poema VII da primeira versão de Turismo, de 1942, presente na seção “Amazônia”, contendo 31 versos.
} 
limpo de qualquer brilho.

Se caminham;

Com sua aura de água

opaca; oprimem

o horizonte. Ou param

para germinar. E então;

irreparavelmente;

absorve-os o crepúsculo. (OLIVEIRA, 2003b, p. 365)

Observamos, na primeira estrofe, a abundância da água que se acumula nos possíveis buracos abertos nas rochas pela erosão, fechando outras fontes, "arcas antigas". A chuva aparece em um caráter dúbio, é o elemento que alimenta as terras, faz nascer as plantas e saciam os homens, mas seu poder na tempestade é também destrutivo, obstruindo fontes que abastecem esses camponeses.

A segunda estrofe parece sugerir o percurso desses camponeses, marcado pelas nuvens que sugerem ao mesmo tempo a abundância e a destruição. Eles, assim como no romance, também parecem estar em peregrinação, estão caminhando. No entanto, não têm a cabeça de lume como no desenho da criança, e sim são acompanhados por nuvens com uma "aura / de água opaca", o que nos permite ler no viés oposto da luminosidade do fogo. A "água opaca” suscita uma noção de cor escurecida, sem que a luz possa passar, sem brilho, como o ar limpo que se espera. Essa água escurecida também remete à imagem de tal elemento impróprio para o consumo, o que nos leva a pensar na sua escassez e na angústia de sobrevivência daqueles que vivem períodos de seca. É este, aliás, o motivo da peregrinação em Finisterra, envolto em uma contradição: ao mesmo tempo em que fogem das trovoadas que destroem as aldeias, os camponeses vão em busca da água criadora de vida, permitindo a germinação dos campos e o abastecimento dos indivíduos e animais. Enquanto as mulheres partem para o sul para cuidar das crianças, os homens marcham ao norte à procura de "Clemência e chuva" (Idem, 2003a, p. 23).

A conexão entre os elementos de Finisterra e outros textos de Carlos de Oliveira leva-nos a uma segunda análise em relação à classificação do romance, também discutida pela crítica, como uma metaficção. Segundo Linda Hutcheon, crítica que procurou estabelecer uma tipologia para tal conceito, "a metaficção é uma ficção sobre o que é a ficção, um texto ficcional que compreende em sua estrutura e composição uma reflexão sobre sua própria identidade narrativa ou linguística" (1980, p. 01, tradução nossa), uma espécie de texto autorreferencial e autoconsciente (do inglês self-consciousness). Dessa forma, a metaficção configura-se, de acordo com a autora, em uma base paradoxal. Por um lado, é um discurso voltado para si, autorreferente, refletindo-se conforme se 
desenvolve. Por outro, sua existência necessita de um compromisso firmado com o leitor, que atua na articulação dos elementos estruturais, sendo um fator ativo na construção do texto.

Em seu estudo, Hutcheon estabelece dois tipos de metaficção; há os textos que são, em sua diegese, autoconscientes e autorreferentes. Há também aqueles que demonstram principalmente uma consciência e referencialidade quanto à constituição de sua linguagem. Assim, estabelece a categoria de textos overt, cujo desenvolvimento explicita a sua autoconsciência por meio de elementos e temáticas ligadas à identidade, e a categoria covert, cujo processo "é estrutural, interno, atualizado. Um texto como este seria autorreflexivo, mas não necessariamente autoconsciente" (HUTCHEON, 2013, p. 56). No tipo overt, "a autoconsciência de um texto toma muitas vezes a forma de uma tematização explícita - por meio de alegoria de enredo, metáfora narrativa ou mesmo comentário narrativo" (Ibid., 58), enquanto que, na forma covert, a autorreflexão é um processo interno, ligado à construção linguística ou diegética. As análises de Hutcheon perpassam diversas narrativas modernas e pós-modernas para melhor elucidar sua tipologia. Porém, não buscaremos analisar se Finisterra se encaixa na primeira ou segunda classificação ${ }^{76}$. Pretendemos apenas pontuar que, em relação a um critério classificatório, alguns críticos leem o romance como uma metaficção e dialogam, em seus estudos, com a categoria elaborada por Hutcheon.

A crítica canadense aponta um aspecto interessante sobre as narrativas metaficcionais que pode ser lido em relação a Finisterra. Para ela, em um romance ligado ao realismo tradicional, o leitor é obrigado a identificar personagens, ações e cenários, o que chama de produtos, sendo imitados pelo autor no desenvolvimento do texto, devendo reconhecer sua semelhança com os elementos da realidade empírica a fim de validar seu valor literário. Assim, a função do leitor é vista em termos pacíficos ou passivos (Ibid., p. 77). A metaficção, por sua vez, explicita as convenções sob as quais se constrói o romance, rompendo os códigos que, então, precisam ser reconhecidos. "O leitor deve aceitar a responsabilidade pelo ato de decodificar, o ato de ler. Perturbado, desafiado, forçado a sair de sua complacência, ele deve conscientemente estabelecer novos códigos

\footnotetext{
76 A dissertação Duas Poéticas individuais. A Metafiç̧ão nas Obras de Carlos de Oliveira e Augusto Abelaira, de Sara Rosa Faria da Silva Vitorino Fernandes, defendida em 2005, na cidade de Faro, Portugal, debruça-se sobre a análise classificatória da metaficção de Oliveira em relação com as categorias definidas por Hutcheon. A mesma autora analisa a temática em sua tese "A Metaficção no Romance PósModernista Português", defendida em 2012 também na Universidade do Algarve, em Faro, Portugal.
} 
a fim de chegar a um acordo com os novos fenômenos literários" (HUTCHEON, 2013, p. 56, tradução nossa).

Ora, o leitor de Finisterra é colocado diante de tal função e precisa cumprir um papel ativo no desenvolvimento do romance em diferentes instâncias. Seu enredo não segue uma temporalidade linear: o presente - com a casa já em ruínas, prestes a ser entregue ao executor fiscal - e o passado - tempo da rememoração do adulto, quando a família ainda discutia possibilidades de salvar a propriedade - misturam-se de forma desconcertante, o que é ampliado pela alternância de vozes que enunciam as diferentes narrativas que aparecem. As marcas que poderiam diferenciar tais vozes são sutis ou, muitas vezes, inexistentes, e o leitor atua na tentativa de ordenar tal discurso para não se sentir perdendo o rumo, expressão de Lepecki.

Cabe ainda ao leitor tentar decodificar - se é que tal tarefa pode ser bem-sucedida - a diferença entre um suposto mundo real e o mundo fantástico criado pelos simulacros, isto é, o desenho da criança e a maquete do adulto. O quinto capítulo ilustra de forma nítida tal esforço. No que tange à narração, misturam-se as vozes, primeiramente, de um narrador aparentemente externo, do adulto e da criança, que discutem sobre o desenho. Em um determinado momento, o homem, com uma lupa, analisa meticulosamente a imagem e direciona-se aos peregrinos: "Onde vão vocês e o vosso fogo?” (OLIVEIRA, 2003b, p. 22). A resposta intriga o leitor: "Respondem todos ao mesmo tempo. Vozes embatem noutras vozes, fragmentam-se em pequenos sons incompreensíveis: um coro áspero que não se entende" (Ibid.). O mundo da simulação da realidade - o desenho torna-se real, os homens têm voz e falam, explicam-se. Depois, outros elementos da gravura falam, como os animais. Assim, ao lermos, ficamos diante do discurso ligado ao mundo concreto (o homem, a casa abandonada e arruinada, a hipoteca) em total consubstanciação com um mundo fantástico, onde os simulacros ganham vida e voz.

Em uma segunda instância, essa resposta indicada pelo narrador, mostrando que todos os peregrinos falam juntos em sons indecifráveis, abre uma possibilidade de leitura metalinguística. Quando diz "Respondem todos ao mesmo tempo. Vozes embatem noutras vozes $[. .$.$] ", o narrador, que aparenta ser uma "persona" distinta do adulto, indica$ um processo que é inerente à construção do próprio romance. Todas as personagens falam, as figuras do desenho também, ao mesmo tempo em que o narrador ainda se pronuncia. Essas vozes tecem-se, embatem-se, misturam-se, obrigando o leitor, assim como o adulto com a sua lupa, a analisar meticulosamente esse ampliado discurso. A verificação de pormenores do desenho feita pelo adulto pode ser lida como uma metáfora 
do plano metalinguístico da posição do leitor, que se aproxima do texto para captar os detalhes e organizá-los, decifrá-los.

Da mesma forma, o fato de os peregrinos conversarem com o adulto, isto é, um elemento do mundo da representação que fala com um indivíduo do mundo concreto, leva-nos a pensar na relação do leitor com os personagens do romance, os quais, assim como os simulacros do enredo, são também formas de representação. Ademais, a obsessão da família pelas representações da paisagem cola-se na própria obsessão do autor pelo mundo da Gândara, da "carência de quase tudo", algo que não somente é autorreflexivo dentro de Finisterra como também aponta para toda a obra ficcional e poética de Oliveira.

Um diálogo profícuo entre o último romance e a obra do autor comumente apontado pela crítica pode ser lido a partir do metatexto "A Fuga", presente em $O$ Aprendiz de Feiticeiro. O ensaio, que data de 1961 e passa por uma revisão em 1967, traz o narrador, aparentemente colado à pessoa de Oliveira, em um refúgio de infância, uma casa que está em um cenário que nos lembra Finisterra e Casa na Duna pela sua condição física. Temos a impressão de que, no tempo presente (tempo da enunciação do texto), o autor foge para uma residência em que morou no passado, à semelhança do adulto que retorna à antiga propriedade em Finisterra. É uma manhã de outubro, na qual ele analisa com atenção a escrita de duas palavras: desolação, desilusão. A preocupação com o rigor estilístico da escrita abre espaço para a rememoração do passado:

Passei a infância aqui. Conheço já a cor incerta, o branco transformado em roxo, o roxo em cinza, da névoa que bate na janela. E o peso do silêncio nas traves do telhado, a humidade irrespirável, a luz difícil (2004b, p. 187).

A coloração "difícil” da luz que incide na casa é recuperada no último livro, assim como a névoa que envolve o local, tornando o ar escuro, um "peso que se move e revolve com lentidão" (2003a, p. 10). A dura luz de "A Fuga" reescreve-se na "violência da luz exterior" (Ibid., p. 11) de Finisterra. A névoa é a mesma, ameaçadora e crescente: "bate na janela, que invade pinhais, aldeias e dunas" (Idem, 2004b, p. 187).

Nesse cenário, alguns elementos apresentados pelo narrador em ordem de itens no ensaio são recuperados no processo de organização, ordenação e reescrita de Finisterra. Ao avivar sua lembrança sobre tempos antigos, o narrador observa as mobílias, que se tornam heranças passadas de pai para filho e depois aos netos. As heranças procuram, segundo ele, "dar algum sentido a uma teia infatigável de partos" (OLIVEIRA, 2004b, p. 
188). No entanto, ele não compreende qual seria tal sentido e aponta uma questão problemática a esse fluxo: "E depois, sem filhos, o rio para em mim, o fio de aranha quebra-se" (Ibid., p. 189). Esse aspecto torna-se justamente uma das problemáticas centrais de Finisterra: o fluxo das heranças também para no adulto, a casa - símbolo da propriedade e do poder familiar - é perdida; o adulto está sozinho, não tem descendência. É um duplo fim: a linhagem extingue-se e a herança e o poder perdem-se. A "engrenagem" de nascimentos e mortes (OLIVEIRA, 2004b, p. 189) é encerrada pelo narrador e, anos mais tarde, pelo homem protagonista do último romance.

O segundo item problematizado pelo narrador de "A Fuga" refere-se à impossibilidade de a representação imitar em perfeição o real, algo que Finisterra recupera pelo viés da obsessão pela paisagem. No ensaio, temos o "céu artificial" (Ibid., p. 190-191) do planetário, o qual "pulsa a um ritmo diferente do céu real” (Ibid.). A última obra, por sua vez, retoma esse aspecto através da construção de diferentes simulacros que tentam reproduzir com fidelidade o instável cenário observado pelo caixilho da janela. Há, em ambos os textos, uma relação paradoxal entre a realidade e a reprodução: os elementos buscam representar com características fidedignas um modelo de real que "em si próprio integra alterações, interpretações próprias a cada estilo que o reproduz e a cada momento de percepção" (SEIXO, 1986, p. 119). O tempo, por si mesmo, produz a instabilidade do "céu real" e da paisagem das dunas, fazendo as luzes incidirem de diferentes formas, permitindo diferentes assimilações do que se vê.

Ora, a reprodução do planetário no ensaio e dos simulacros de Finisterra aponta para a relação entre o sujeito que apreende a realidade e a realidade em si, mostrando que o fator subjetivo impediria, a princípio, uma representação fiel do elemento concreto. $\mathrm{O}$ "céu artificial" de "A Fuga" antecipa o céu objetivo, afinal o narrador gostava de ir ao local à tarde para observar o céu noturno. O tempo do indivíduo que deseja apreciar o céu não está de acordo com o tempo em que a noite surge. Para observá-la, portanto, ele recorre à representação, o céu que simula o elemento real. A condição física do planetário, obviamente muito menor do que as dimensões do céu real, obriga-a a desrespeitar a ordenação e o volume entre os astros. O tempo real não pode ser respeitado também, e o universo aparece concentrado, em uma velocidade irreal. Para o narrador, o "céu artificial" promove uma experimentação do céu concreto, mas não uma reprodução fiel deste, o qual já é, por sua vez, um "templo imperfeito" ou "demasiadamente perfeito" (OLIVEIRA, 2004b, p. 192), com o seu próprio tempo e seu funcionamento. 
Levanta-se, assim, dois aspectos que serão obsessivamente trabalhados em Finisterra: o paradoxo entre a representação objetiva de um elemento instável por natureza e a influência da subjetividade nesse processo. O capítulo VI apresenta tal questão a partir das reflexões do pai e da mãe do protagonista. Pela fotografia, o pai observa que este objeto capta a paisagem inversamente, mas indicando seus elementos essenciais: "A imagem não é perfeita (escapam-lhe alguns pormenores), mas foi o ponto de partida (OLIVEIRA, 2003a, p. 26). A máquina fotográfica permitiria "surpreender as coisas sem grande margem de erro" (Ibid.). Para o pai, apreender a paisagem pela fotografia seria transportá-la para o mundo interno da casa de forma objetiva: "Magia, imaginação, limitam-se a colher o rigor submerso da realidade. Os números, a geometria, em que o mundo repousa" (Ibid.).

A foto é uma forma de reprodução da realidade, uma re-produção, isto é, um ato de fazer aparecer novamente ou produzir-se novamente um elemento, mostrando aquilo que a luz, em seu efeito sobre o filme, capta. Para o pai, fotografar é um ato de rigor, um ato racional em que se capta a geometria base do real. A mãe, no entanto, não consegue concordar com o marido. "Tanto mais que me interessa um único pormenor. Mas basta o pormenor (não é?), o engano no algarismo, e as contas saem erradas" (Ibid., p. 27). Esse detalhe, para ela, é o indivíduo. Mesmo colocando à parte temas como imperfeições da máquina e a semelhança artificial com a visão, ela observa que as pessoas podem “contaminar" (Ibid., p. 28) o real, isto é, justamente, a imaginação contamina o real. O olhar humano, a subjetividade opera na produção do objeto. O fator subjetivo produz, então, aquilo que reproduz o real. Para ilustrar sua opinião, ela aponta à almofada em que fez sua pirogravura: "Uma gravura abstracta. Perto da geometria, da arquitectura submersa nas coisas. Mas foi minha imaginação (partindo do real, eu sei) a construí-la. Magia para filtrar o mundo, dar-lhe algum sentido" (Ibid.).

Nesse sentido, a fotografia nos coloca um certo paradoxo: seria, segundo o pai, a captação concreta e artificial da paisagem que vê, porém ela tem um "gênio" próprio, como observa Roland Barthes, em seu ensaio A Câmara Clara (1984). Tal "gênio" relaciona-se à fala da mãe. O processo de fotografar pode ser objetivo e mecânico, mas o que se revela é um momento da realidade, um olhar sobre o cenário concreto. De acordo com a crítica de arte Susan Sontag, "imagens fotografadas não parecem manifestações a respeito do mundo, mas sim pedaços dele, miniaturas da realidade que qualquer um pode fazer ou adquirir" (2004, p. 08), pois o primeiro passo reside em olhar para o objeto, e isso parte de cada indivíduo que o pratica. 
Na concepção do pai, re-produzir é algo que se produz de novo, é fazer re-aparecer algo idêntico, imitando-o, criando uma imagem ou elemento igual, com uma pequena "margem de erro". Uma fotografia, assim, produz em um pequeno espaço - o papel, o filme - uma "imitação" de um cenário ou de um ser. Ela é, porém, uma simulação de um olhar específico sobre o objeto, o que já a distanciaria da possibilidade de ser e de representá-lo total e objetivamente, segundo a opinião da mãe. Além disso, a foto mantém concretamente o instante atual, ainda que a sua existência deste seja breve. Conforme verifica o crítico John Berger,

Uma imagem é uma visão que foi recriada ou reproduzida, é uma aparência, ou um conjunto de aparências, que foi separada do lugar e do tempo em que primeiro apareceu e preservada - por alguns momentos ou alguns séculos. Toda imagem personifica uma maneira de ver. Mesmo uma fotografia (1972, p. 9-10, tradução nossa).

Ainda segundo Berger,

Imagens foram produzidas, primeiramente, para evocar as aparências de algo que estava ausente. Gradualmente, tornou-se evidente que uma imagem poderia viver mais tempo do que aquilo que ela representava. Em seguida, ela passou a demonstrar o modo como algo ou alguém tinha olhado em determinado momento - e, portanto, por implicação o modo como o sujeito tinha sido visto por outras pessoas (Ibid., p. 10, tradução nossa).

Assim, a fotografia nos permite pensar de que modo a questão da representação em Finisterra é problematizada. Há, na criação, a personificação de uma maneira de ver. Em cada simulacro há uma forma de se pensar o mundo. Para além do romance, esse aspecto estende-se à obra de Carlos de Oliveira segundo Pedro Eiras: "ângulos de visão diferentes podem criar realidades diferentes [...]" (2014, p. 117).

Outro objeto de representação que promove essa reflexão, mas, desta vez, em uma dimensão fantástica, é o desenho da criança, cujos personagens ganham vida e voz tanto em Finisterra como no ensaio "A Fuga". Neste, conforme o menino risca os traços para criar um animal, essa personagem já se comunica com o desenhista, pedindo-lhe, inclusive: "põe-me garras maiores". A criança, então, questiona de que cor as prefere, e o animal diz: "Tanto faz" (OLIVEIRA, 2004b, p. 193). Em Finisterra, o diálogo desdobra-se entre o criador e as criaturas, isto é, a criança e os elementos do desenho, e ainda com o adulto, que fora o criador no passado. Essa conversa ganha uma perspectiva surreal e pode ser lida como um desdobramento subjetivo do processo de produção em uma chave metalinguística, além de revelar, como ocorre ao longo da obra, uma 
associação entre o presente e o tempo da memória. O mundo fantástico do desenho, cujos elementos falam e explicam suas formas e as suas intenções, pode ser compreendido como um mecanismo metalinguístico em que o escritor estabelece uma relação com o mundo empírico e objetivo que busca representar e a percepção subjetiva deste, o modo como olha para tal realidade. Recuperamos, a partir dessa ideia, a noção de mímesis ${ }^{77}$ trabalhada por Aristóteles que pressupõe não um conceito de imitação estrita do objeto a ser representado somente, e sim uma relação entre este, a realidade (natureza) e o espectador.

Aristóteles inicia sua Poética afirmando que a "poesia é imitação" - sejam dos grandes mitos, sejam dos grandes feitos heroicos, sejam objetos e elementos do mundo real. O autor afirma que imitar é "congênito ao homem". Porém, há um dado importante neste texto. O pensador grego também afirma que o poeta é mais um "fabulador" do que um "metrificador", isto é, ele imita, mas também cria ações e objetos que devem ser verossímeis. Ora, nesse sentido, podemos pensar que, ainda que seja congênita ao poeta a imitação, a criação também é um fator determinante. A imitação contempla, assim, a visão daquele que a imita, ou seja, há de se considerar o fator da subjetividade nesse processo daquele que apreende um fato ou um objeto e o recria por meio da linguagem. A imitação, logo, é composta a partir de uma noção de representação que supõe a relação com o mundo real a ser imitado e também aquele que atua, que cumpre a função de poeta.

Sob esse aspecto, Finisterra propõe um diálogo metalinguístico com o ato de criação e de representação em si, de forma autorreflexiva, e com o mundo lírico e ficcional de Oliveira. Manuel Gusmão, em sua leitura Finisterra. O Trabalho do Fim: reCitar a origem, insere tal romance entre as concepções de metatexto e metarrepresentação. Para ele, o livro, que pode ser lido como uma arte poética,

[...] é ao mesmo tempo regido pela autorreflexividade, um metatexto na medida em que cita, alude e refere outros textos (no caso, integrantes de um mundo textual) que atribuímos a um mesmo nome de autor e um texto que se apresenta como uma representação das representações. Sabemos que em larga medida o funcionamento de Finisterra como arte poética passa pelo modo como este texto dispõe de forma insistente ou obsessiva e, ao mesmo tempo, intermitente e constelada, como seus "objetos" ou constructos diegéticos e figurais, uma série de artefatos, ações ou atividades". (2009, p. 91).

\footnotetext{
${ }^{77}$ A relação entre o conceito de mímeses e a obra poética de Carlos de Oliveira foi elaborada pelo Prof. Dr. Leonardo Gandolfi em sua dissertação de mestrado Mundo Comum e Povoamento da Paisagem - Ler com $O$ Aprendiz de Feiticeiro de Carlos de Oliveira, defendida em 2007, na Universidade Federal Fluminense, em Niterói, Rio de Janeiro.
} 
Assim, considera que a obra se constitui em torno das representações dos artefatos, como o desenho e a maquete elaboradas pelo protagonista, representando-as verbalmente. Ao mesmo tempo, é representado por elas, mostrando-se como metarrepresentação.

A obra também é lida como uma forma de metaficção pelo crítico Osvaldo Silvestre em seu ensaio Slow Motion. Carlos de Oliveira e a Pós-Modernidade. Em diálogo com a teoria de Linda Hutcheon, o autor analisa como Finisterra se constrói a partir da ideia de representação e metarrepresentação, lida pela intensa relação entre as personagens e suas obsessões de recriar o mundo visto e apreendido pelo olhar. Porém, tais ideias fixas demonstram que tal realidade observada não pode ser reconstituída em sua totalidade e perfeição, uma vez que, em cada olhar, reside a subjetividade. Assim, o real não existiria se não fosse por suas formas de representação, a qual contempla, necessariamente, a visão subjetiva daquele que o apreende e o reconstitui.

O crítico ainda observa a presença da "Nota Final" da obra, que seria determinante na sua concepção metaficcional. Assim como os artefatos elaborados pelas personagens, o próprio romance revela-se, por meio da sua "advertência final", um objeto imperfeito e incerto, cujo desenvolvimento é um entre vários outros supostamente possíveis. Metalinguisticamente, a nota estabelece um diálogo com o leitor, informando-o do seu processo de construção e sua autoconsciência como objeto de representação, mostrandose, ao mesmo tempo, como "produto e processo" (expressão usada por Hutcheon e retomada por Silvestre), afinal o autor revela que sua produção nasce de um intenso e atento trabalho de decifração de velhos papéis, os quais são organizados de acordo com elementos da produção: a caligrafia, os tipos de tinta, a tipologia da datilografia, entre outros. Oliveira expõe, então, sua criação como resultado de um processo incompleto e até imperfeito, sem a certeza de uma única interpretação. Como representação da realidade, como mimese, Finisterra é, assim como os artefatos construídos ao longo de seu enredo, uma das possibilidades de apreensão do real, sendo inexato e, naturalmente, permeado pela subjetividade. A nota ratifica a noção de mimese aristotélica, pois coloca o ato criador não como simples imitação exata, e sim como um produto nascido da interação entre o real e aquele que o observa.

O último romance de Carlos de Oliveira coloca-se, portanto, em um fluído e dinâmico campo categórico, indicando uma linha tênue entre a poesia e prosa e, ao mesmo tempo, revelando-se como produto e processo de criação e de representação. Também em sua "Nota Final", o autor observa que essa obra lembra ainda outra "(sua) casa destruída" 
(2003a, p. 141), referindo-se implicitamente a Casa na Duna. É justamente a partir de tal analogia que se destaca em Finisterra o exímio trabalho de uma linguagem poética que o afasta das suas obras ficcionais anteriores, ainda que observemos a recuperação da temática da ruína de uma família e da sua propriedade. É com base nesse aspecto que buscaremos analisar a seguir de que modo Finisterra pode ser lido - ou não - como uma reestruturação alegórica da temática social abordada por Oliveira em sua obra poética e ficcional, sobretudo considerando a ruptura que o escritor promove em relação à linguagem presente nos outros romances ligados ao Neorrealismo.

\subsection{O deslocamento da linguagem e a reflexão sobre a representação do real}

A "Nota final" de Finisterra nos chama a atenção sobre o parentesco entre este romance e a primeira obra ficcional de Oliveira, Casa na Duna, indicando que esse vínculo não seria grave, "dada a frequência com que sucede aos romancistas repetirem o essencial (para eles) em vários enredos" (2003a, p. 141). O que seria grave então? Para o autor, a resposta é simples: "Grave seria, com certeza, não as ter aprofundado um pouco" (Ibid.). De fato, podemos nos questionar sobre o que se refere tal aprofundamento, sobretudo se nos apegarmos ao fato pontual temático de ambas as narrativas: a destruição de uma propriedade e, consequentemente, de uma família. Cabe-nos uma questão: Finisterra seria em que medida uma revisitação de Casa da Duna? E ainda teríamos de problematizar tal pergunta, afinal, pelo intenso processo de revisão e reescrita do primeiro romance, como podemos entender a ideia de "revisitação"?

A crítica Rosa Maria Martelo procura, em seu ensaio "Casas Destruídas: a revisitação de Casa da Duna em Finisterra, de Carlos de Oliveira” (2000), analisar tal aspecto e nos indica que a recuperação do tema central ocorre de forma "substancialmente diferente" no último romance, sendo, na verdade, "a desconstrução de Casa na Duna" (Ibid., p. 252), uma vez que se mostra como uma problematização dos fundamentos ideológicos do primeiro romance e também dos "princípios estéticos de matriz realista" (Ibid.) que orientaram a produção e a reconstrução da primeira obra. Segundo a autora, temos de considerar ainda a estrutura discursiva que já fora problematizada por Oliveira na revisão das edições de Casa da Duna e que seria, certamente, um ponto a ser aprofundado pela última narrativa.

Nesse aspecto, talvez o termo "revisitação" não seja suficientemente complexo para compreendermos o vínculo que se estabelece entre os dois enredos e ainda para 
percebemos que lugar Finisterra ocupa na obra de Oliveira em seu percurso ficcional ligado ao Neorrealismo. Se em Casa na Duna observamos a questão central de uma família que se desfaz pelos avanços capitalistas em sua região, no último romance essa temática se estende a um plano extremo que impulsiona uma ruptura na estrutura discursiva, como claramente observa Martelo, e um rompimento agudo com a linguagem ficcional outrora adotada pelo autor, que incessantemente a revisita e a recria nas diferentes edições de seus romances. Partindo de nossa proposta de uma leitura comparativa de Finisterra em relação Casa na Duna e Pequenos Burgueses, procuraremos pensar em que medida a "desconstrução" (termo de Martelo) vista na última obra pode indicar uma reconfiguração do autor diante da estética neorrealista. Afinal, seria possível ler a destruição familiar de Finisterra como um total rompimento com o quadro ideológico que Oliveira buscou seguir em seus romances anteriores por meio de uma mudança extremamente marcante na linguagem que apresenta?

A leitura do último romance de Carlos de Oliveira nos conduz à rememoração de um adulto sobre seu passado, sua família e sua propriedade, a qual está prestes, no momento "atual", a ser entregue a um executor fiscal para cumprir uma hipoteca, mostrando-nos o fracasso financeiro desse núcleo. Percorrendo essas lembranças, colocamo-nos diante de personagens como o pai e o tio, que tentam, cada um a seu modo dentro da narrativa, recuperar a propriedade da iminente perda para o Estado. A fábrica de porcelanas, vislumbrada pelo tio, permitiria que a família e a propriedade se reerguessem através da criança, o herdeiro central desse grupo que expressa uma constituição patriarcal daquele meio. Seu desejo é obter a fórmula de uma porcelana que seja "leve, capaz de voar" (OLIVEIRA, 2003a, p. 37), algo que seria de interesse dos alquimistas também.

Naturalmente, a tentativa de recuperação dessa propriedade por meio de uma fábrica nos sugere, imediatamente, a construção da fábrica de telhas e tijolos conduzida por Mariano Paulo em Casa na Duna. O objetivo de ambas as fábricas seria similar: salvar a propriedade familiar por meio da recuperação financeira diante de adversidades econômicas impostas pelo contexto. No primeiro romance, observamos que tais obstáculos resultam do desenvolvimento capitalista na aldeia de Corrocovo. Em Finisterra, porém, não temos essa informação de forma clara. Mas as condições para a instalação das fábricas também se aproximam: na propriedade dos Paulos, havia barro o suficiente para a produção de tijolos; na segunda, havia também tais facilidades: "O resto é fácil. Temos a propriedade cheia de sílica, argila e caulino. Talvez um pouco fundos, 
mas escavaremos. Quanto à lenha, não falta nos pinhais: sem falar do fogo (quase) sagrado que dorme nas florestas submersas" (Ibid., p. 38). O autor nos apresenta, assim, a noção de que a propriedade poderia prover uma solução para um momento de grave crise, somando-se à concepção das fábricas, cuja ideia parte de um dos familiares envolvidos diretamente com o declínio econômico enfrentado.

Chamamos atenção a esses dois acontecimentos porque, de forma evidente, eles nos permitem fazer a leitura de recriação do primeiro romance no último. Problemas semelhantes, soluções semelhantes. Entretanto, o modo como tal possibilidade de recuperação é tratada em ambos os livros nos aponta aspectos diferentes importantes para pensarmos a ideia de releitura de Casa na Duna em Finisterra, seja como desconstrução, seja como reelaboração da temática central: o declínio de uma propriedade patriarcal e a sua perda de poder em um contexto econômico em constante mudança - o capitalismo.

Um dos aspectos diferentes fundamentais entre as duas obras reside na concretização da ideia salvadora. Vimos que Mariano Paulo constrói, de fato, sua fábrica e tenta, ao longo dos capítulos, produzir tijolos e telhas em quantidade suficiente para recuperar seu poder financeiro. Isso não se torna possível, pois com a ampliação da infraestrutura local, muitas fábricas de maior produtividade se instalam em Corrocovo e região, e os Paulos não conseguem arcar com os preços mais baixos. A solução demonstra-se, na prática, incapaz de salvaguardar as estruturas socioeconômicas de uma família que estava há muitas gerações no poder. Nos capítulos XXII e XXIII, percebemos que Mariano e seu funcionário Firmino depositam uma grande esperança na fabricação dos materiais de construção, algo que não se concretiza já no capítulo XXVI, com a chegada de concorrentes à pequena produção dos Paulos. Esses acontecimentos são narrados através de uma linguagem clara e objetiva, e o autor ainda inclui um trecho que se estrutura como um balancete empresarial: o dono da propriedade pensa e busca resumir como caminham as finanças e as questões pessoais em um pensamento lógico e exato, com a ocorrência de marcadores que criam uma espécie de lista. Como observa Vítor Viçoso,

Casa na Duna é, pois, a metáfora da instabilidade e da decadência duma mitologia familiar e dos seus símbolos pregnantes (a ruptura na herança) e da simultânea emergência duma mitologia popular feiticista irradiada pelas histórias que atravessavam a Gândara e que a voz do autor escutou com espanto e temor na sua infância (lobisomens, almas penadas, bruxarias) (2011, p. 165). 
Ainda que em Finisterra, se buscarmos uma comparação com o primeiro romance, apareçam semelhanças no eixo temático do enredo, temos uma diferença brusca resultante principalmente do uso de uma linguagem que se aproxima muito mais da poesia do que de uma suposta objetividade sugerida pela questão financeira. $\mathrm{O}$ tio afirma sobre sua solução: "Quero outra porcelana (leve, capaz de voar): a dos fornos quiméricos" (OLIVEIRA, 2003a, p. 37). Tal adjetivo recupera o substantivo "Quimera", do grego "Khímaira": "monstro mitológico que se dizia possuir cabeça de leão, corpo de cabra e cauda de serpente" 78 , lançando fogo pelas narinas. Sendo criada por uma união entre Tifão e Équidna ${ }^{79}$, um monstro metade mulher, metade serpente, a Quimera surge dentre os mitos que formam a primeira geração divina para os gregos. Tal criatura vivia no monte de Lícia e devastava toda a região. Ióbates, rei do local, pede então ao herói Belerofonte que a mate. "Cavalgando Pégaso, o herói aproximou-se do monstro, mas teve o cuidado de guarnecer de chumbo a ponta da lança. Com o calor das chamas lançadas por Quimera, o chumbo se derreteu e a matou", conforme analisa Junito Brandão (1986, p. 244).

Para esse autor, a Quimera apresenta um complexo simbolismo ligado a "criações imaginárias nascidas nas profundezas do inconsciente" (BRANDÃO, 1986, p. 245). Ela, assim, configura:

[...] desejos exasperados pela frustração, os quais acabam por transformar-se em fonte de sofrimentos. O monstro seduz e destrói a quem a ele se entrega. Não se podendo combatê-la de frente, é necessário persegui-la com ardor e surpreendê-la em seus refúgios mais profundos (Ibid).

Ela ainda representaria uma espécie de "deformação psíquica”, ligada à "imaginação fértil e incontrolada" (Ibid.), expressando o perigo de uma exaltação imaginativa (CHEVALLIER, 1986, p. 866). Com o tempo, a partir da literatura grega clássica e sua apreensão pelos autores posteriores, cria-se o adjetivo "quimérico", o que vem a significar algo impossível, "uma ideia falsa" ou "a vã imaginação", conforme explica Chevallier (Ibid.).

É interessante, nesse sentido, observarmos que o tio da criança, em Finisterra, afirma querer a obtenção de uma porcelana tão leve que seria forjada em "fornos quiméricos”. Tal adjetivação pode apontar, por um lado, que ele vislumbra sua porcelana

\footnotetext{
78 Verbete "quimera" em Dicionário Eletrônico Houaiss.

79 Équidna, por sua vez, é criada por Crisaor - nascido a partir do sangue de Medusa - e Calírroe, filha de Oceano (Cf. BRANDÃO, 1986, p. 155). É irmã das Górgonas. (CHEVALLIER, 1986, p. 866).
} 
como algo sublime, divino, tão perfeita em leveza e em qualidade que seria um mito. Possivelmente, podemos ler a qualidade dos fornos em relação ao fogo que o monstro Quimera solta pelas narinas. Seria, então, uma porcelana moldada no calor de uma divindade, algo mitológico. Esse fator aparece ainda na sua fala quando diz: "Alquimia quer dizer milagre. Transmutou metais, recriou o ouro, deu passos que ninguém suspeita" (OLIVEIRA, 2003a, p. 37). Se os alquímicos se interessam pela porcelana, como a personagem observa, é porque sua produção desperta a equilibrada mistura de elementos para se chegar a um produto muito valorizado. No entanto, os alquímicos chegariam à porcelana sem dificuldades, "com uma perna às costas" (Ibid.). Segundo o tio, fabricar esse material leve "pode estar ao alcance de um leigo. Questão de paciência e trabalho" (Ibid.). Seria, assim, um milagre? Talvez, mas um milagre possível àqueles que se dedicam à pesquisa e à produção, algo de que ele não iria desistir.

Por outro lado, ao apresentar a adjetivação "quiméricos", o autor pode nos indicar justamente a noção de que o desejo de tal familiar é, na realidade, fruto de sua imaginação. A porcelana que ele deseja, sendo a salvação da sua propriedade e família, não passaria de um exercício imaginativo, de um desejo de sua mente sobre algo que na prática se mostraria impossível. Para se obter uma porcelana tão sutil, "capaz de voar”, os fornos em que a produziriam não poderiam ser nada menos que quiméricos, imaginários. $\mathrm{O}$ intuito do tio é encontrar a "porcelana imponderável". Ele a imagina de forma sublime: "muito perto da névoa: translucida e mudando de forma (sem se quebrar)" (OLIVEIRA, 2003a, p. 37). Tal produto ganha ares de mistério, sua forma modifica-se, sua aparência permite que a luz a atravesse. Como criar uma porcelana que não se pode pesar ou ainda cujo peso seja insignificante de tão leve? É uma porcelana milagrosa, misteriosa, diferente de tudo o que o mundo real pôde observar. O adjetivo "imponderável" também se relaciona a algo que "não pode ser calculado, nem previsto" ${ }^{80}$, o que reforça a ideia de "imaginária" que podemos ler a partir da descrição do tio. Sua obstinação reside em um desejo de conseguir fabricar um produto quase milagroso, mas fruto de sua imaginação. Com o decorrer do enredo, percebemos que nunca fora encontrada tal fórmula, e a queda da família e da propriedade se tornam inevitáveis.

Ora, esse trecho revela de forma muito clara o poder da linguagem poética em Finisterra, cujo discurso passeia entre uma rede polissêmica de significações, como já observou Lepecki (1988, p. 51). Nesse aspecto, podemos compreender como Carlos de

\footnotetext{
${ }^{80} \mathrm{Cf}$. verbete “imponderável” no Dicionário Eletrônico Houaiss.
} 
Oliveira elabora, nesta obra quase híbrida, um deslocamento da linguagem em relação ao que se observa no primeiro romance e nas primeiras edições de seus outros textos. Conforme analisa Roland Barthes, em sua aula inaugural de Semiologia Literária no Colégio de França, a língua apreendida e trabalhada pela literatura não é somente um uso prático, e sim uma encenação (2004, p. 18). Essa ideia é trabalhada a partir da concepção do crítico de que a literatura apresenta uma força semiótica, isto é, um discurso no qual o autor joga com os signos em vez de destruí-los (Ibid., p. 26).

Para um escritor, e naturalmente isto se aplica aos modernos também, é preciso deslocar-se diante da língua trivialmente imposta como uma estrutura de poder, a língua gregária, como Barthes se refere. Tal deslocamento age unido à teimosia da escrita: "Teimar ${ }^{81}$ quer dizer afirmar o Irredutível da literatura: o que, nela, resiste e sobrevive aos discursos tipificados que a cercam: as filosofias, as ciências, as psicologias; agir como se ela fosse incomparável e imortal” (Ibid., p. 24). “Teimar ${ }^{82}$ quer dizer, em suma, manter ao revés e contra tudo a força de uma deriva e de uma espera. E é precisamente porque ela teima, que a escritura é levada a deslocar-se" (Ibid., p. 25). Ao deslocar-se, o escritor transporta-se "para onde não se é esperado, ou ainda e mais radicalmente, abjurar ${ }^{83}$ o que se escreveu (mas não, forçosamente, o que se pensou), quando o poder gregário o utiliza e serviliza” (BARTHES, 2004, p. 26).

O crítico elabora sua concepção sobre a linguagem considerando que ela é um objeto em que se inscreve o poder, formando a língua como expressão obrigatória de um conjunto de códigos que permitem, por um lado, a formação social, e por outro a concretização do poder, o qual pode ser visto na e pela língua. Por seu caráter gregário, o idioma se constitui como uma forma de classificação, o que pressupõe sempre uma opressão diante daqueles que a praticam. É com base nesta ideia que Barthes analisa que o falante de uma língua vive em uma dupla relação com ela: ora há a servidão, ora há o poder: somos mestres e escravos ao mesmo tempo (Ibid., p. 14-15). A literatura surge, pois, como uma espécie de "trapaça" à língua: um artifício magnífico que permite a compreensão da linguagem fora do poder, numa "revolução permanente" (Ibid, p. 16). Conforme explica, o texto é "o florescimento próprio da língua" (Ibid.). Florescer aqui relaciona-se à ideia de "jogo de palavras": a obra não é um instrumento da mensagem, mas a encenação da linguagem.

\footnotetext{
${ }^{81}$ Destaque feito pelo autor.

82 Idem.

83 Idem.
} 
Desse modo, podemos pensar no discurso híbrido que nos apresenta Oliveira em seu último romance. A linguagem não aparece como um simples instrumento, as palavras não comportam apenas um intuito objetivo de comunicação de uma mensagem, de um suposto olhar crítico do escritor. $\mathrm{Na}$ realidade, as palavras apresentam "projeções, explosões, vibrações e sabores", como observa Barthes em relação ao texto literário (BARTHES, 2004, p. 20). Ao mobilizar diferentes significações para uma mesma expressão, o autor neorrealista promove uma encenação da língua, e não sua mera utilização instrumental, resultando, nas palavras barthesianas, um saber dramático (Ibid., p. 19). A teimosia de Oliveira reside na sua tentativa de transportar a palavra para onde ela não é esperada, distanciando-se de expressões gregárias, levando-a sempre para mais longe, "longe dos topoi da cultura politizada", ou seja, distante do discurso coletivo, opondo-se à "in-diferença", nas palavras de Barthes (Ibid., p. 33).

A aula inaugural de Roland Barthes ainda nos auxilia a pensar sobre um segundo aspecto de Finisterra ligado à linguagem: a sua força de representação. Como vimos, a ideia de "representar" o real é, constantemente, questionada nesse romance, o que nos leva a refletir em que medida a linguagem trabalhada na obra é capaz de representar fielmente um quadro social de declínio econômico da estrutura patriarcal na sociedade capitalista. Se julgarmos que o discurso de Casa na Duna nos revela de forma mais objetiva e clara a condição socioeconômica criticada, criamos uma distinção bem demarcada entre essa obra e a última de Oliveira, na qual a ideia de se criar um simulacro que explicite o mundo real é posta em reflexão ao longo de todo o enredo. O deslocamento da linguagem proposto pelo autor português passa, inevitavelmente, por um questionamento de seu caráter representativo, afinal a língua pode ser vista como um dos simulacros que compõem o texto, como a maquete, a fotografia, o desenho da criança e a pirogravura.

Em suas análises, Barthes procura indicar que a linguagem também se constrói a partir da sua força de representação, como mimesis. "Desde os tempos antigos até as tentativas da vanguarda, a literatura se afaina na representação de alguma coisa. O quê? Direi brutalmente: o real", afirma o crítico francês, reiterando que o homem busca constantemente, na história literária, essa possibilidade de uma língua que recrie a realidade (2004, p. 20). Conforme o autor,

O real não é representável, e é porque os homens querem constantemente representá-lo por palavras que há uma história da literatura. Que o real não seja representável - mas somente 
demonstrável - pode ser dito de vários modos: quer o definamos, com Lacan, como o impossível, o que não pode ser atingido e escapa ao discurso, quer se verifique, em termos topológicos, que não se pode fazer coincidir uma ordem pluridimensional (o real) e uma ordem unidimensional (a linguagem). (Ibid.)

A obra literária seria, pois, essa recusa: o trabalho árduo da linguagem não é paralelo ao real, sendo fundamental a inadequação entre eles.

No entanto, para o autor francês, a literatura residiria em uma espécie de tensão entre representação do real e inadequação da linguagem a esse mesmo real; enquanto texto, a obra busca "o próprio fulgor do real" (2004, p. 21), sendo, assim, realista. Ao mesmo tempo, ela é "irrealista", uma vez que se coloca diante do impossível paralelo entre a língua e a realidade na própria tentativa de representação. A escrita move-se entre tal impossível. "Que não haja paralelismo entre o real e a linguagem, com isso os homens não se conformam, e é essa recusa, talvez tão velha quanto a própria linguagem, que produz, numa faina incessante, a literatura" (Ibid.). Barthes conclui, desse modo, que a força mimética da linguagem é, na prática, uma função utópica, pois a literatura acredita ser sensato esse desejo do impossível (Ibid.).

A tensão entre o real e a representação da linguagem, que gera "o desejo do impossível" estende-se paralelamente, em Finisterra, às tentativas de captação da realidade por objetos artísticos elaborados pelas personagens, como o próprio protagonista e sua maquete fantástica. A representação é questionada, aparece em crise no desenvolvimento do romance híbrido. A foto do pai não pode contemplar todos os detalhes de um instante da paisagem. A pirogravura em almofada da mãe "sucumbe" às incitações subjetivas do imaginário, levando a personagem a se afastar da atividade artística por um tempo não definido. É justamente sobre esse aspecto que o capítulo XIX se constrói: o narrador se desloca, assumindo a voz da mãe, em uma oscilação entre $1^{\mathrm{a}} \mathrm{e}$ $3^{\mathrm{a}}$ pessoas. Ela pretende, no início do capítulo, refugiar-se em seu estojo de pirogravura, mas a ferrugem e o desgaste do objeto revelam que havia muito tempo sua última utilização.

A mãe mostra que a preocupação com as condições do estojo é inútil: "não me sirvo desse estojo há muito" (OLIVEIRA, 2003a, p. 77). Entre parêntesis, a personagem explica-se: "(desisti de perseguir a realidade ou, melhor, cansei-me)". "Perseguir a realidade" parece ser algo contraditório à mulher, uma vez que, em sua expressão artística, ela não pode evitar que a sua imaginação contamine com traços subjetivos aquilo que está sendo representado, isto é, a paisagem, como nos aponta o capítulo V. O sujeito, 
conforme ela explana, faz parte da realidade e, sem ele, que sente, nada faria sentido. A apreensão das coisas do mundo passa pelo crivo da subjetividade, o que se mostra, para a mãe, como um conflito à representação fiel do real. Para a mãe, representar e expressar um sentimento abstrato pelo objeto não são ações que se distinguem, logo a fidelidade do olhar - e da captação objetiva de um instante da paisagem - estará sempre em conflito:

\begin{abstract}
A geometria submersa da realidade tem (pelo menos) duas lógicas contraditórias. Uma força interior conduz-me cegamente (deixei também de analisá-la) às formas simples da fidelidade. Amo (e isto significa: distingo) um objeto; não preciso de mais para concretizar o sentimento abstracto que me ordena (no campo do real) sentimentos inconciliáveis. Ainda hoje não sei se vale a pena fugir-lhes. Pouco importa. Ao fim e ao cabo, pormenores. (OLIVEIRA, 2003a, p. 77-78)
\end{abstract}

Reproduzir um objeto, ou a própria paisagem, conecta-se ao sentimento - à subjetividade - que ele lhe desperta. Afinal, o que ela concretiza em sua pirogravura é uma imagem fiel à realidade ou é o sentimento abstrato pelo objeto? Ela parece cansar-se dessa reflexão, é algo que já não lhe importa. São pormenores.

Se a mãe demonstra cansaço para perseguir fielmente o real, diante da impossibilidade do conflito entre objetividade e subjetividade, o filho, quando adulto, crê que representar fielmente a paisagem em uma maquete pode guiá-lo em suas andanças noturnas pela grande propriedade, como nos indica o capítulo XVI. Insone, ele procura caminhar pela propriedade sem "tropeços", por isso opta por elaborar milimetricamente um esquema do local. "Trabalho de paciência e rigor. Construo um esquema topográfico geral e pratico-o de olhos fechados até transformá-lo num simples dado da memória" (Ibid., p. 65). De acordo com os seus passos, ele mede a distância entre cômodos e móveis e, matematicamente, reduz as medidas para criar seu simulacro. Mecaniza as dimensões de seus passos para "encontrar equivalências na escala métrica (sem muitos erros)" (Ibid.).

$\mathrm{O}$ adulto vale-se de medidas, ângulos e divisões, aparatos objetivos para representar fielmente as distâncias que ele pretende percorrer no escuro da madrugada. Anda entre os objetos de decoração e os cômodos, usufruindo de uma certa liberdade que o faz pensar no acaso, o que nos sugere também um conflito: ele anda livremente ou "matematicamente", condicionado pelo distanciamento concreto e contabilizável dos móveis nos cômodos? Uma maquete perfeita, em escala reduzida, exige o rigor que os passos livres entre os objetos não podem oferecer. Ele sabe disso: “A imitação do acaso 
não é perfeita (inútil sublinhá-lo)" (Ibid., p. 66). A personagem nota que andar livremente pode oferecer-lhe certas surpresas que impactam o trabalho final da maquete:

Altera a constância das correntes de ar: sopram sempre do mesmo lado, facilitando ou dificultando os passos, conforme a direcção que tomo. Modifica-as também qualitativamente, obriga-as a produzir efeitos psicológicos diversos. Imagino uma tempestade, com a ajuda ou desajuda do vento; limito-lhe o ímpeto ao sopro doméstico do corredor; e apuro sensações residuais opostas: umas vezes, contrariedade; outras, satisfação. Leis do acaso (em miniatura), aplicadas para ordenar a insónia; geometria variável que detém (e modela) o escuro em termos suportáveis (OLIVEIRA, 2003a, p. 66).

A "geometria variável” já nos indica um cenário em que as medidas matemáticas - em teoria, objetivas e fiéis ao real - são colocadas em questionamento. A maquete como simulacro está à mercê do acaso, que guiará o adulto em seus passos, e da sua própria imaginação e memória.

O uso de termos como "medir, registar ${ }^{84}$, imitar" mostra-nos um deslocamento em relação aos seus sentidos de apreensão objetiva do elemento real, afinal o que está sendo assimilado e captado para a construção da maquete não é simplesmente algo mensurável, como a distância de um móvel ao outro dentro de uma sala, por exemplo. O adulto deseja captar impressões de sua memória e a organização arbitrária do acaso - como os efeitos de uma ventania ou tempestade sobre a casa - em termos objetivos, o que se demonstra em conflito na prática. Oliveira vale-se da sinestesia nesse capítulo para indicar que as sensações subjetivas, medidas objetivas e itens abstratos misturam-se na elaboração do simulacro maquete: "Os rumores da casa gelam nas galerias farelentas (o frio petrifica a própria serradura interior da madeira). Uma superfície densa e delgada (o silêncio), onde as gotas batem e deslizam até à última vibração" (Ibid.). Substantivo abstrato, o silêncio torna-se concreto como uma superfície que reverbera o som das partículas de água que nele caem. É interessante observar que o silêncio pode ser entendido como a ausência de som ou ruídos, revelando o estado da não fala, cessão de comunicação oral e, por extensão de sentido, pode se relacionar, muitas vezes, ao estado subjetivo das personagens. Além disso, ainda representa uma imagem do mistério, do sigilo, do secreto, o que pode ser lido pelo viés sobrenatural, assustador e sombrio.

No momento da construção da maquete, o silêncio da casa é profundo - uma afirmação que já pressupõe ela mesma um deslocamento de significações. Adjetivá-lo

\footnotetext{
${ }^{84}$ Em português europeu, o verbo "registrar" é grafado sem a letra "R", "registar".
} 
como "profundo" envolve uma percepção subjetiva da sensação de não ouvir nada (seria uma não sensação?). Oliveira, no entanto, intensifica tal imagem ao concretizá-lo como um objeto no qual poderiam bater gotas de chuva. Torna-se palpável, quase visível, revelando o modo como a personagem interpreta tal ausência de ruídos na residência. Se considerarmos o enredo, o momento em que o adulto constrói a maquete é justamente um período de solidão e de um mergulho introspectivo nas memórias da infância. Ele está sozinho pela última vez na casa que deixará em breve de ser sua propriedade, pois será entregue ao executor fiscal. O silêncio ganha, assim, uma apreensão motivada e influenciada pelos aspectos subjetivos dessa personagem.

Após a sua construção, tal simulacro ganha ares fantásticos quando os pequenos grãos luminosos aparecem ao adulto e se instalam sobre o esquema estrategicamente organizado. Como vimos, a personagem reconhece que, apesar de todos os cálculos e medidas, "a imitação do acaso não é perfeita" (OLIVEIRA, 2003a, p. 66). Enquanto percorre a casa, em uma atitude de confirmar aquilo que foi medido, ele percebe que os grãos que surgem criam ilusões de óptica envolvendo cores e movimentos. São três as esferas luminosas que aparecem diante da visão do adulto em seu percurso pela casa. Como se estivessem dotadas de vida, esses elementos movem-se e fixam-se acima da maquete, o que lhe sugere a semelhança de uma "estrela à deriva" (Ibid., p.85). Nesse ponto, o leitor já se depara com o questionamento sobre a semelhança do simulacro à realidade, afinal as estrelas estão acima da paisagem como os grânulos luminosos. Porém, tais estruturas parecem-se com estrelas, mas não as são. São elementos fantásticos que criam sua própria ordem na maquete elaborada.

Carlos de Oliveira, por meio de tal passagem, insere-nos mais uma vez na reflexão acerca da realidade do simulacro. Tal como o desenho infantil - repleto de elementos que se distanciam das medidas da paisagem real - e a pirogravura da mãe, a maquete também revela, em seus ares fantásticos, a influência subjetiva do adulto em sua tentativa de recriar milimetricamente o cenário em que habitava e que logo perderá. Em suas análises acerca de simulação e simulacros, o sociólogo Jean Baudrillard afirma que a simulação “põe em causa a diferença do 'verdadeiro' e do 'falso', do 'real' e do 'imaginário' (1991, p. 10). Aquilo que é simulado é produzido, não podendo ser visto como um fato da natureza. Os simulacros, em Finisterra, aparecem como reproduções, uma representação do real que, partindo de um princípio de equivalência, jamais consegue, de fato, ser uma produção objetiva. Seja pela imaginação da mãe, seja pela visão do instante captada pelo 
pai, seja pela presença dos grãos luminosos, cada objeto elaborado aponta que o cenário reproduzido modifica-se diante das experiências subjetivas das personagens que o criam.

Nesse âmbito, o enredo nos leva a questionar se tais simulacros são o reflexo de uma realidade profunda ou se mascaram e deformam tal realidade, dois aspectos levantados por Baudrillard sobre a simulação e a representação (Ibid., p. 13). É em tal chave também que inserimos a questão da linguagem em Finisterra. Como signo, ela representa fielmente uma realidade que seria analisada e criticada pelo autor? E mais, em que medida tais signos - que ganham um tom poético na obra - colocam o último romance numa posição de distanciamento em relação aos critérios neorrealistas seguidos por Oliveira no restante de sua obra ficcional?

Tal debate, no último romance, ultrapassa o plano do enredo e engloba a própria criação da obra partindo da representação do real por meio de simulacros e, por que não, da linguagem. Observamos que o adulto protagonista, por meio de suas memórias da infância, está centrado em um conflito sobre o papel do sujeito na representação. O pai defende a objetividade da máquina que capta um instante da paisagem, formando o objeto artístico que [quase] explicita o que o olhar vê. À mãe, por sua vez, cabe "realçar a síntese entre o sujeito e o real representado (o objecto)", como observa Viçoso (2011, p. 177). Sob a perspectiva da mulher, "o sujeito é, em última instância, a geratriz empenhada da construção de sentido das coisas no plano estético" (Ibid.). O real da arte seria, então, uma estruturação entre a objetividade da paisagem e a percepção subjetiva daquele que a produz, considerando que este sujeito esteja historicamente situado.

Transpondo e estendendo essa reflexão ao âmbito de criação de Finisterra, temos a linguagem de um autor que viveu historicamente situado na Gândara, viu com seus olhos os sofrimentos e a sobrevivência dos povos que habitam tal região e teve as mazelas vividas tatuadas em si mesmo, como ele nos diz em seus ensaios. Ora, essa linguagem pretendeu-se objetiva descrevendo um conflito familiar de decadência? Podemos dizer que não, afinal o obsessivo processo de Oliveira em rever e reestruturar sua obra ficcional aponta-nos para um questionamento que o afasta da mimese "etnografista", expressão de Viçoso (2011, p. 176), da égide neorrealista. Sua matéria criativa reside naquilo que viu, mas também naquilo que sentiu, que lhe fora tatuado e naquilo de que se lembra. A memória e a objetividade interagem, confundem-se, apontam ora para aquele que nos fala, o protagonista, ora para aqueles que não teriam voz, como os camponeses do desenho infantil. 
Como observa o crítico, "não são pois os camponeses típicos de um registo realista que aqui deambulam e falam com as cabeças aureoladas pelo fogo, mas os camponeses oníricos e sulcados [...] a emergirem epifanicamente no texto [...] (VIÇOSO, 2011, p. 176). O resultado da interação de tais fatores nos leva a uma leitura da palavra poética, contaminada pelo real objetivo e pela matéria imaginária das lembranças. $\mathrm{O}$ fato enfrentado pelo adulto ao encarar suas lembranças da casa prestes a ser perdida é que a sua casa - objetiva e afetivamente - está à mercê do processo de perda e de indiferenciação. Não foi possível à família resguardá-la da decadência objetiva de um contexto burguês capitalista. Mas as memórias estão influenciadas por aquilo que cada personagem vê em sua propriedade. A casa não pode ser captada objetivamente, sua posse será perdida. Tampouco sua captação pelos afetos e pela memória também não podem ser objetivos ou concretos: o sujeito é parte integrante dessa interação. Sua lembrança e sua reprodução da casa em simulacros não podem apagar a marca daquele que o produz.

Talvez esse aspecto - não sei se poderíamos chamar de um dilema - é o que se reproduz no âmbito da linguagem híbrida de Finisterra. De acordo com as observações de Viçoso, Carlos de Oliveira, mesmo sendo alvo de críticas de estetas mais ortodoxos neorrealista, defendia que, "embora o ponto de partida do escritor fosse o real historicizado, seria, em última instância, a subjetividade e a técnica do artista (o processo criativo), também elas condicionadas historicamente a determinar a estruturação da obra de arte" (VIÇOSO, 2011, p. 174). Retomando o tema de Barthes, Oliveira coloca-se no local de deslocamento de uma linguagem comum e objetiva para algo além, um registro que comtemple a experiência afetiva e memorialística de um indivíduo artista que está situado no contexto da Gândara e do qual carrega lembranças tatuadas. Sua linguagem é uma entidade viva entre a língua que busca representar o real e a língua que não pode representar o real. Não objetivamente. Porém, afetiva e memorialmente sim, o que se expressa no híbrido registro entre a língua ficcional e a língua poética. Finisterra é uma obra em que vemos o aspecto do "teimar" - como explicou-nos Barthes - levando a linguagem a um espaço de deslocamento e questionamento do real, isto é, a concreta história de uma família prestes a enfrentar a decadência material e social. Nas palavras de Viçoso,

Em Finisterra, a regressão à infância e a progressão para o fim [...] que estruturam o romance, são dois modos de fundir a vida e a morte, a esperança e o desespero, os sinais e sua indiferenciação. É o reencontro tenso do autor com os temas e as palavras que fizeram dele, contra a 
aridez do mundo, apesar da sua excepcionalidade, um representante peculiar do Neorrealismo. (2011, p. 175).

O romance transita através do tempo - da fatalidade em perder a casa em breve - e da recuperação das memórias lá vividas. É ainda uma revisitação a termos essenciais da sua obra, segundo críticos como Viçoso e Silvestre, mas que passam por um projeto de alquimia, de transfiguração e de deslocamento, usando a linguagem como um caminho pelo qual o fantasioso e o memorial formam e definem a experiência concreta com a paisagem e o povoamento reais desse ambiente. A linguagem de Finisterra rompe com a possível intenção de que ela possa representar o mundo objetivo como ele é somente pela apreensão do olhar e dos significados. A memória e a subjetividade são pilares tão importantes quanto o processo de criação de um enredo que nasce de um homem marcado pelas mazelas da Gândara.

\subsection{Fim da terra, terra do fim: a alegoria da transformação de um sistema social}

Em seu processo de retorno à casa, o protagonista de Finisterra explora o local em andanças noturnas, tentando esquivar-se dos móveis e das paredes a partir do exercício de rememorar a posição desses elementos na propriedade. Tal atividade, no entanto, não

parece ser algo simples. É preciso lembrar-se da casa que existe no momento presente isto é, quando o protagonista já é um homem adulto - mas também daquilo que ele se recorda do seu passado, quando era uma criança a desenhar a paisagem. Ele elabora, então, sua maquete, a qual deveria reproduzir o ambiente que está prestes a ser tomado pela ação da natureza. Convence-se de que caminha ao acaso pelas divisões da mansão no intuito de recolher as medidas para seu plano de representação. Em uma reflexão do protagonista ou do narrador, vemos que imitar o acaso é algo imperfeito (OLIVEIRA, 2003a, p. 66), sobretudo se considerarmos as condições da casa no momento da vida adulta da personagem. A casa desfaz-se com o passar do tempo, as galerias estão "farelentas" (Ibid.) e o frio externo parece invadir o cenário interior, misturando-se sinestesicamente ao silêncio daquele espaço. Oliveira nos indica que a casa desmanchase, desmonta-se diante da tentativa do adulto de recuperar pela memória aquele lugar que sempre fora seu, mas agora já não o é mais.

Nesse âmbito, o autor nos coloca diante de um processo múltiplo de desintegração da propriedade central do romance. Diversos trechos nos indicam que fisicamente a casa está se desmanchando, madeiras puídas, vidros opacos e sujos, umidade a invadir pelas 
frestas os espaços amplos, tecidos desbotados... O desmantelamento do cenário é visível a todo instante para o leitor, enquanto acompanha o processo de reconstrução do ambiente desempenhado pelo adulto por meio de sua maquete. Diferentemente de sua mãe, que abandona a atividade da pirogravura por estar cansada de "perseguir a realidade", o adulto recorre à sua memória para reelaborar a propriedade e a paisagem, talvez em uma última tentativa de manter a casa para si, já que ela está prestes a ser entregue ao Estado. Entretanto, a casa cede às forças naturais, sendo tomada pela enigmática gisandra no momento final.

Ainda que o adulto tente concretizar suas recordações em um esquema geométrico que represente sua casa, a perda dela é inevitável não somente para a força natural, mas, principalmente, pela força do Estado, que toma a propriedade da família diante do não pagamento da hipoteca. Podemos dizer que este é um segundo processo de desintegração apresentado por Carlos de Oliveira que ocorre concomitantemente à ação da natureza. $\mathrm{O}$ desmantelamento é, logo, algo mais amplo e profundo: ao mesmo tempo que a propriedade será entregue ao Estado, a própria noção da família entra em crise: o adulto é o último integrante daquele núcleo. Sem descendentes, a propriedade também se arruinaria. Em seu discurso ficcional-poético, Finisterra nos apresenta a decadência de uma família e de sua propriedade, pontos fundamentais do sistema econômico vigente: o capitalismo.

Se no capítulo anterior estudamos a crítica referente às relações de classe e de exploração por meio da história de Mariano Paulo, o último romance de Oliveira mostrase, novamente, diante de uma análise incisiva sobre os moldes econômicos das áreas rurais de Portugal. A Gândara, que não é nomeada em Finisterra, surge como a possibilidade de um cenário que está em constante transformação. A natureza muda a cada rajada de vento que toca as dunas, sendo impossível captá-la em sua totalidade, como representa a fotografia do pai. As pessoas que habitam tal lugar também se modificam com o passar do tempo: temos os primeiros peregrinos, que partem em busca da água de que tanto necessitam, e também os donos da terra, proprietários rurais que controlam a atividade agrícola, base do sistema econômico português durante o período salazarista. $\mathrm{O}$ povoamento - segundo termo do subtítulo da obra - mostra-se em transformação ao longo da história: a partida de uns, a decadência de outros, algo que já se observara no desenho fantástico da criança. A finisterra, terra do fim, é, na realidade, um contexto em constante modificação: seja a natureza, seja a população que a povoa. 
Vimos que Casa na Duna inscreve-se na literatura portuguesa como uma obra neorrealista não ortodoxa e podemos nos questionar como ler Finisterra nesse âmbito, considerando seu aspecto crítico. Observamos a ruptura do autor com um modelo ficcional mais tradicional e com a linguagem da prosa, porém é possível afirmar um rompimento com a temática crítica neorrealista que já definia Oliveira na esfera da fícção? Para abordarmos tal reflexão, procuraremos analisar a obra de acordo com a ideia da decadência do núcleo central familiar diante da perda da propriedade para o Estado. O escritor nos apresenta, por meio do colapso de uma estrutura central do capitalismo, o modo como esse sistema articula classe e Estado, criando, assim, uma alegoria das transformações econômicas que contemplam a queda da família, a perda da posse de bens e o fortalecimento estatal.

Nesse sentido, a leitura de Finisterra nos orienta a uma dupla análise: por um lado, há a decadência do núcleo familiar, o fim da linhagem e a crise do patriarcado que são problematizados, sobretudo na figura do adulto/criança, cuja descendência parece não existir, e na personagem da mãe, o "mal necessário" ao sistema patriarcal, sendo responsável pela continuidade das gerações de herdeiros, o que é a base da família burguesa pela transmissão de bens. Ambas as personagens colocam em questionamento o sistema patriarcal, como a nossa leitura vai indicar. Por outro lado, de forma complementar, há a crise da propriedade privada, elaborada a partir da perda desse bem para o Estado, representado pelo executor fiscal. Esses dois aspectos complementam-se no desenvolvimento do romance de Oliveira, criando uma perspectiva crítica de contradições presentes no sistema vigente, o capitalismo. Há ainda como fator central à análise a tomada da casa pela gisandra que revela, ao fim, a força da natureza. Ainda que tal elemento se dissemine pela propriedade na conclusão da obra, estamos diante de uma contradição inescapável inerente ao sistema econômico capitalista: a impossibilidade de retorno a um estado natural pela presença forte do Estado. Finisterra, desse modo, aponta não somente às contradições do próprio capitalismo mas também a uma visão distópica da alternativa comunista que surge no imaginário neorrealista.

Em seu ensaio "A Fuga", Carlos de Oliveira revela reflexões que tem quando visita a antiga casa onde morou e parece nos dar indícios do enredo que será elaborado em seu último romance. O autor posiciona-se diante da hereditariedade e da transmissão de bens, fatores complementares na constituição das famílias. Ele nos diz: 
Um tempo enorme gasto a resguardar madeiras, metais trabalhados, entregues pelos pais aos filhos, pelos filhos aos netos. O rio das heranças, mobílias, oficinas, terras, procurando dar algum sentido a uma teia infatigável de partos. Que sentido? Não compreendo bem. E depois, sem filhos, o rio para em mim, o fio de aranha quebra-se. Não entro nesta ordenação de factos, de gente, nesta engrenagem que ultrapassa o nascimento e a morte de cada um, ou melhor, termino-a. (2004b, p. 189)

Tal engrenagem que supera os nascimentos e as mortes é, justamente, o funcionamento da transmissão de bens que sustenta as bases da família dentro do sistema capitalista. De pai para filho, de filho para neto e assim sucessivamente, a posse é garantida ao núcleo familiar por gerações. Em sua reflexão, Oliveira indica que tal "fio de aranha" quebra-se, pois, sem filhos, os bens perdem-se, são vendidos, são repassados a outrem. Não produzir descendência é determinar o fim de uma linhagem patriarcal, o que está no centro do desenvolvimento do capitalismo e será problematizado em Finisterra.

Assim como o autor de "A Fuga", o protagonista do último livro de Oliveira parece não ter filhos. Ele chega à casa de sua infância sozinho, com o objetivo de entregar as chaves do local ao executor fiscal. Não é citada a presença de uma esposa ou de descendentes ligados ao adulto, o que fortalece o impacto da perda da propriedade. Sem herdeiros, por lei, a posse da casa seria perdida de qualquer maneira. O declínio do núcleo familiar, portanto, não se refere apenas à questão da hipoteca, mas também à crise da transmissão de bens. Quando criança, a personagem era vista pelo tio como aquele que poderia salvar a propriedade por meio da fabricação da porcelana. No entanto, a criança torna-se um adulto sem família, solitário. Os bens são perdidos, a linhagem patriarcal é interrompida: o "fio de aranha" quebra-se.

Esse destino já aparece como um pressentimento no capítulo XXVI, quando uma personagem feminina, provavelmente a cozinheira da casa, revela que não consegue esquecer do episódio em que uma aranha cobre a cabeça da criança no berço. Conforme analisa Gusmão (2009, p. 44), a imagem da cabeça do bebê encoberta pelo aracnídeo pode ser lida como a decapitação da família, o fim da linhagem. Ela nos diz: "Sobretudo, o pressentimento. Toca-me ao de leve e queima: esta criança nasceu para destruir a família" (2003a, p. 198). A criada ainda enxerga o protagonista pelo viés do estranhamento:

Não pretendo julgá-lo; deus me defenda da arrogância. Transmito-lhe o aviso: se alguém entregar as chaves desta casa a um estranho, é naturalmente a criança que as aranhas procuraram no berço (Ibid.) 
O destino pressentido pela criada parece se cumprir: solitário, o adulto rememora sua vivência na casa, mas não pode mais mantê-la. Não poderá transmitir a seus filhos. Sua família finda com a sua morte, e o Estado torna-se o detentor da propriedade.

Esse tema em Finisterra sugere, para muitos críticos como Gusmão e Luís Mourão (in: SILVESTRE, 2011), uma revisitação à crise familiar vivenciada pela família de Mariano Paulo com a morte prematura do único filho, Hilário. A "maldição dos Paulos" se aproximaria, assim, da previsão da criada sobre o destino da criança que se torna um homem só, sem filhos, encerrando a linhagem familiar. O fim da herança retoma o viés crítico de Oliveira ao abordar a crise do patriarcalismo, base fulcral do sistema capitalista. Friedrich Engels, em sua obra A Origem da Família, da Propriedade e do Estado, analisa o modo como a família individual constitui-se como alicerce da sociedade burguesa. Em um processo de modificações sociais, homens e mulheres que viviam em grupos e compartilhavam a paternidade das crianças passam a formar núcleos individuais centrados na presença de um pai - que é o detentor de bens - e de uma mãe - responsável pela função doméstica da reprodução de descendentes (s/d, p. 101).

Segundo o autor, o processo histórico da formação da família tradicional burguesa baseada na hereditariedade dos pais é algo que surge na medida em que a sociedade se desenvolveu no sentido do sistema de acumulação de bens (Ibid., p. 109). "A família é produto do sistema social e refletirá o estado de cultura desse sistema" (Ibid.). Conforme a concepção materialista, Engels afirma, retomando as ideias de Marx sobre o tema, que a produção e a reprodução da vida imediata são fatores centrais para o desenvolvimento histórico. De um lado, observa-se a produção de "meios de existência" (Ibid., p. 08), como produtos alimentícios, roupas, habitação e instrumentos necessários para a construção desses elementos. De outro, está a produção do homem em si, a continuação da espécie. Ambos os fatores, em diferentes níveis, determinam o desenvolvimento das sociedades e das instituições nelas presentes. Engels demonstra em seu ensaio que o modo da produção material é o fator preponderante que condiciona tal processo social e, nesse âmbito, verifica-se a formação da família como núcleo dos sistemas sociais criados historicamente. De acordo com o pensador:

A ordem social em que vivem os homens de determinada época ou determinado país está condicionada por essas duas espécies de produção: pelo grau do desenvolvimento do trabalho [...] e da família [...]. quanto menos desenvolvido é o trabalho, mais restrita é a quantidade dos seus produtos e, por consequência, a riqueza da 
sociedade; com tanto maior força se manifesta a influência dominante dos laços de parentesco sobre o regime social. (ENGELS, s/d, p. 08).

Nota-se, entretanto, uma mudança importante ligada a esses dois fatores:

No marco dessa estrutura da sociedade baseada nos laços de parentesco, a produtividade do trabalho aumenta sem cessar, e, com ela, desenvolvem-se a propriedade privada e as trocas, as diferenças de riqueza, a possibilidade de empregar força de trabalho alheia, e com isso, a base dos antagonismos de classe (Ibid., p. 09).

A sociedade modifica-se a partir da criação desses novos elementos sociais: a configuração antiga das diferentes sociedades, baseada em laços gentílicos, desagrega-se com a formação de classes distintas. O choque entre tais grupos leva ao desenvolvimento de sociedades organizadas em Estado, “cujas unidades inferiores já não são gentílicas, e sim unidades territoriais" (Ibid.). O regime familiar, então, torna-se completamente submetido às relações de propriedade, portando, em livre curso, as contradições das classes sociais e os seus conflitos, o que, para Marx e Engels, constitui o conteúdo da história escrita. Dessa reflexão, surge a célebre frase do Manifesto Comunista: "a história de todas as sociedades até hoje existentes é a história das lutas de classe" (MARX; ENGELS, 2010, p. 40).

Engels passa a analisar, na obra referida, os estudos antropológicos de Lewis Henry Morgan sobre as sociedades pré-históricas anteriores aos povos da Antiguidade, nas quais aparecem diferentes formações do núcleo familiar. As investigações sobre tais elementos permitiram uma melhor compreensão das estruturas sociais presentes na Grécia antiga e em Roma, por exemplo. O ensaio busca, a partir de outros modelos familiares anteriores à formação dessa civilizações, identificar de que maneira fatores que promoveram mudanças drásticas na configuração social, como a domesticação de animais, o desenvolvimento da caça e da agricultura e, posteriormente, a concepção de propriedade privada, orientam o entendimento sobre família e de que modo se estrutura como núcleo da sociedade patriarcal e burguesa a família monogâmica. Engels localiza sua análise no período denominado por Morgan como a passagem do Estado da Barbárie - marcado pelo surgimento da criação de gado e agricultura por meio do trabalho humano - ao Estado da Civilização, definido como o estágio em que os homens continuam a elaborar os produtos naturais, com o surgimento da indústria e da arte (ENGELS, s/d, p. 38). 
Não cabe ao escopo deste trabalho uma detalhada análise das teorias de Morgan e Engels sobre o modelo de família anterior ao que conhecemos como núcleo monogâmico, porém é justamente a passagem de um modo ao outro que se torna relevante à nossa leitura de Finisterra. Um aspecto fundamental para a concepção tradicional de família que conhecemos nos dias atuais - a monogamia das relações matrimoniais - ocorre, como analisa o pensador alemão, por elementos da estrutura socioeconômica que mudam seriamente a apropriação de bens produzidos pelos indivíduos. A formação de um núcleo familiar composto por um homem e uma mulher passa a ocorrer, historicamente, na transição do Estado Selvagem - período definido pela apropriação dos produtos da natureza pelo homem, prontos para serem consumidos - para o Estado da Barbárie (ENGELS, s/d, p. 70). A nova organização familiar é chamada de família sindiásmica e, a partir dela, a sociedade evolui para a concepção monogâmica que conhecemos.

É justamente na transição do modelo sindiásmico para o monogâmico que Engels localiza a relação entre a família e a propriedade privada. Como analisa o autor, "se não tivessem entrado em jogo novas forças impulsionadoras da ordem social, não teria havido qualquer razão para que da família sindiásmica surgisse outra forma de família" (Ibid., p. 71). Porém, tais forças surgiram e modificaram a ordem social pautando-se no acúmulo de riquezas. A transição do Estado de Barbárie para o Estado de Civilização é marcada pela domesticação de animais e a criação de gado, que levaram, nas palavras de Engels, a "mananciais de riqueza até então desconhecidos" (Ibid.), o que suscitou, necessariamente, uma reorganização das relações sociais. $\mathrm{O}$ autor explica que

Até a fase inferior da Barbárie, a riqueza duradoura limitava-se pouco mais ou menos à habitação, às vestes, aos adornos primitivos e aos utensílios necessários para a obtenção e preparação dos alimentos: o barco, as armas, os objetos caseiros mais simples. Os alimentos deviam ser obtidos dia a dia. Agora, com as suas manadas de cavalos, camelos, burros, bois, carneiros, cabras e porcos, os novos pastores [...] haviam adquirido riquezas que precisavam apenas de vigilância e dos cuidados mais primitivos para se reproduzirem em proporção cada vez maior e fornecerem abundantíssima alimentação de carne e de leite. (Ibid., p. 71-72).

Ora, diante da ampla gama de alimentação e de novos bens - os animais criados colocava-se a seguinte questão para o núcleo familiar: a quem pertenceria essa nova riqueza? Anteriormente, quando a acumulação de bens era restrita a elementos simples como vestes e utensílios, sem dúvida, a posse era do grupo, da gens. Entretanto, com o desenvolvimento rápido e quantitativo dos rebanhos e dos produtos deles derivados, a 
situação muda e o grupo familiar também. Além disso, a escravatura na fase inferior da Barbárie também já havia sido inventada. A posse dessas pessoas também promove uma mudança nas estruturas sociais então vigentes. Conforme analisa Engels:

Ao introduzirem-se, porém, a criação de gado, a elaboração dos metais, a arte do tecido e, por fim, a agricultura, as coisas ganharam outra fisionomia. [...] A família não se multiplicava com tanta rapidez quanto o gado. Agora eram necessárias mais pessoas para os cuidados com a criação [...] (ENGELS, s/d, p. 73)

Os rebanhos, os produtos feitos a partir deles e a criação de novos produtos originados do trabalho com os metais levam, dessa forma, a uma valorização dos escravos, que agora poderiam ser usados no trabalho agrícola, e, claro, dos próprios animais domesticados.

É nesse contexto que a família sindiásmica e a sociedade então baseada no matriarcado perdem força. Se, durante os estágios selvagem e início do bárbaro, os grupos sociais baseavam-se no direito da mãe - a ela e à sua gens perteciam os filhos, o pai não tinha a importância que conhecemos -, agora a dinâmica sofre intensas modificações.

\begin{abstract}
O matrimônio sindiásmico havia introduzido na família um elemento novo. Junto à verdadeira mãe tinha posto o verdadeiro pai [...]. de acordo com a divisão do trabalho na família de então, cabia ao homem procurar a alimentação e os instrumentos de trabalho necessários para isso; consequentemente, era, por direito, o proprietário dos referidos instrumentos, e em caso de separação levava-os consigo, da mesma forma que a mulher conservava os seus utensílios domésticos (Ibid.).
\end{abstract}

Dessa maneira, segundo os costumes dessa forma de sociedade, era o homem responsável pela posse do gado e, mais adiante, do novo instrumento de trabalho, os escravos. Contudo, os filhos desse homem não herdavam tais bens, pois as relações sociais baseavam-se na linhagem feminina. Assim, se o homem viesse a falecer, seus bens seriam incorporados no seu grupo original, a gens a que pertencia. Os filhos, pelo direito materno, pertenciam a gens da mulher e não tinham acesso aos bens deixados pelo pai, mesmo sendo "o verdadeiro pai".

Nota-se que, à medida que as riquezas aumentavam, o poder e o papel de importância do homem também cresciam, o que os levou a modificar a dinâmica de como a sua herança seria tomada em favor dos filhos. Mas, conforme observa Engels (s/d, p. 74), “isso não se poderia fazer enquanto permanecesse vigente a filiação segundo o direito materno. Esse direito teria de ser abolido, e foi-o". O autor observa que tal mudança é uma revolução - uma das mais profundas nas relações sociais humanas na História. A 
reorganização foi relativamente simples. Passou-se a considerar que os filhos, em vez de fazerem parte do grupo de origem da mãe, seriam parte da gens paterna. O direito hereditário feminino é, então, abolido, assumindo-se a filiação e o direito hereditário paternos. Observa-se, portanto, que a importância do homem dentro da família e de seu grupo de origem modifica-se intensamente com o desenvolvimento da agricultura e da consequente acumulação de bens. Segundo Marx (ENGELS, s/d, p. 75), essa mudança foi natural: passa-se de uma sociedade pautada na linhagem feminina para o nascimento do patriarcado, o qual se torna a base da organização familiar e, por extensão, das relações sociais travadas socioeconomicamente.

Diante de tais mudanças, surge um novo modelo familiar que se baseia na monogamia: "Para assegurar a fidelidade da mulher e, por conseguinte, a paternidade dos filhos, aquela é entregue, sem reservas, ao poder do homem [...] (Ibid., p. 77). Assim, o núcleo familiar vai refletir o novo processo econômico de acumulação, posse e transmissão de bens, passando a ser determinado pela autenticidade de um pai como pai verdadeiro e de uma mãe em um contrato de fidelidade. Ora, a monogamia, desse modo, surge como uma necessidade de garantir a paternidade do herdeiro, o que não era possível nos grupos primitivos. Nesse sentido, as relações monogâmicas são um instrumento para se garantir o direito paterno, algo que fora instituído já em sociedades da antiguidade, como os gregos. Segundo o pensador:

De modo algum [a monogamia] foi fruto do amor sexual individual, com o qual nada tinha em comum, já que os casamentos, antes como agora, permaneceram casamentos de conveniência. Foi a primeira forma de família que não se baseava em condições naturais, mas econômicas, e concretamente no triunfo da propriedade privada sobre a propriedade comum primitiva, originada espontaneamente (s/d, p. 85).

Partindo de uma perspectiva econômica, formam-se as famílias monogâmicas, ligadas diretamente à possibilidade de transmissão de bens. Engels analisa que esse modelo configura-se pelo predomínio do homem, e a sua finalidade objetiva é a procriação, a formação de descendentes que serão herdeiros - porém, para que isso seja efetivado, é necessária a certeza irrefutável de que o pai é, de fato, o pai biológico, o que exige da mulher a sua total monogamia para que os frutos de seu matrimônio possam um dia se tornar donos dos bens paternos.

Engels observa que a monogamia tem como objetivos "a preponderância do homem na família e a procriação de filhos que só pudessem ser seus para deles herdarem" (Ibid., p. 86). Essa forma de união, logo, não surge "como uma reconciliação entre homem 
e mulher e, menos ainda, como a forma mais elevada de matrimônio" (Ibid.), mas, sim, aparece como uma forma de submissão de um gênero pelo outro, ou, nas palavras do pensador, uma forma de escravização. Nasce, desse modelo, não somente a preponderância do patriarcado mas também a primeira divisão do trabalho: entre homens e mulheres na vida social e doméstica (Ibid.):

A primeira divisão do trabalho é a que se fez entre o homem e a mulher
para a procriação dos filhos. Hoje posso acrescentar: o primeiro
antagonismo de classes que apareceu na história coincide com o
desenvolvimento do antagonismo entre o homem e a mulher na
monogamia; e a primeira opressão de classes, com a opressão do sexo
feminino pelo masculino. (Ibid.)

Desse modo, Engels afirma, retomando ideias que elaborou juntamente com Marx, de que a monogamia foi um grande processo histórico que, ao lado da escravidão, uniu progresso social a um retrocesso, pois "o bem-estar e o desenvolvimento de uns se verifica à custa da dor e da repressão de outros" (Ibid.).

Tal mudança aguda na sociedade acompanha processos históricos e o desenvolvimento socioeconômico de diferentes povos e chegam à base do sistema burguês. O matrimônio por conveniência, que visa à acumulação e à transmissão de bens, torna-se um dos pilares das relações burguesas e passam a ser defendidos pelo Estado em favor do direito à família e à propriedade privada. A monogamia - sobretudo feminina, aos olhos de Engels - e o direito paterno levam à supremacia masculina e ao seu domínio. Assim, a submissão da mulher a seu marido e a necessidade de continuação da linhagem paterna mostram-se fundamentais para a manutenção e acumulação de bens no modelo burguês de desenvolvimento econômico que se estendem até os dias atuais.

Em Finisterra, Carlos de Oliveira nos indica uma visão crítica a esses dois pilares de estruturação social. Responsável pela linhagem paterna, a mãe aparece ligada ao seu papel fundamental na procriação familiar, o qual aparenta ser falho para a continuação do núcleo. No capítulo 17, o adulto relata a memória infantil de observar a mãe em uma espécie de ritual que pode ser lido como uma tentativa de incentivar a fertilidade, como aponta Gusmão (2009, p. XX). No intuito de minimizar as marcas no pescoço deixadas pelo crucifixo, a mãe retira o suco viscoso de duas gisandras e passa com força sobre sua pele, revelando o cheiro enjoativo do líquido pelo quarto. A questão reforça-se no capítulo seguinte, no qual se descreve uma cena em que há um recipiente de vidro com um feto dentro, estando selado com parafina. 
O narrador prossegue afirmando que o feto representaria talvez "a primeira falha na sequência familiar" (OLIVEIRA, 2003a, p. 74). "Uma das intrusas trouxe para dentro da casa o óvulo doente: deteriora (quando não extingue) o outro gérmen, introduzindo-o (desvitalizado) no fluxo hereditário" (Ibid.). A mulher, na adjetivação do narrador, é a intrusa: o mal necessário à continuidade da família. Ela é, porém, responsável pela falha nesse processo - seu óvulo doente corrompe a geração, ameaçando o núcleo familiar. "Intrusa" é um adjetivo revelador: ao mesmo tempo em que mostra a mulher como alguém externo ao grupo familiar, indica seu caráter pejorativo de invasora, de usurpadora, como apontam os sinônimos dessa palavra. O intruso é aquele que entra sem direito, sem permissão, que invade um local ou um grupo sem ser autorizado. É também aquele que tenta apoderar-se de bens ou ocupar imóveis de forma clandestina ${ }^{85}$. Etimologicamente, está ligado ao verbo intrudere, que significa "introduzir-se à força"

A intrusão da mulher relaciona-se à progressiva diminuição do seu poder no grupo familiar que acompanhamos através das análises de Engels. Com o fim da linhagem materna, sua posição social resume-se à geração de filhos e seu papel na família não é visto como parte da continuidade consanguínea, o que a deixa em uma posição de inferioridade, sendo um elemento que se introduz na família, e não advém naturalmente desta. Oliveira condensa na qualidade de intrusa a visão crítica sobre a situação da mulher que se apresenta nas famílias pautadas no direito paternal. Intensificando o papel da introdução sem permissão, o narrador compara o óvulo à gisandra: ambos seguem princípios próprios de degeneração e são capazes de alternar as leis da genética a seu modo.

Ao manter-se o feto em um bocal de vidro, o narrador sugere que esta é uma lição à invasora:

Dadas as circunstâncias, a imagem, o golpe na retina choca sem piedade: não espere complacência (nem perdão) a culpada (?). É esse o objetivo do bocal; ou antes, era: a casa a desmoronar-se desmorona a disciplina, que vem (como se sabe) do equilíbrio econômico (OLIVEIRA, 2003a, p. 74).

O trecho mostra a relação da concepção de um herdeiro à manutenção da disciplina dada pelo "equilíbrio econômico". O aprendizado da mulher é constante: o recipiente exibe a criança morta antes de nascer como um exemplo duro. É esta a sua função, gerar, mas

\footnotetext{
85 Dicionário Eletrônico Houaiss da Língua Portuguesa.

86 Dicionário Escolar Latino-Português. Brasília: 1962, Ministério da Educação e da Cultura, versão digitalizada.
} 
falhou. Lembre-se disso, intrusa. O óvulo dela é capaz de modificar as leis da genética, como sugere o autor, mas também as leis socioeconômicas. O futuro de uma família e a sua prosperidade condensam-se na hereditariedade - do sangue e dos bens. Passar aos filhos aquilo que se possui é o modo de manter-se no domínio financeiro e social. Sendo uma intrusa, sem voz no núcleo familiar, a mulher está destinada à procriação. Seus sentimentos, diante do filho morto é a frustração (OLIVEIRA, 2003a, p. 74), porém não é somente ela que se decepciona. O feto exposto relembra a frustração dos "desígnios alheios" (Ibid.). Diante do desapontamento com o insucesso de seu papel, a mulher guarda o bocal com o "fantasma no formol" no alto de um armário, "por trás dos florões de cedro" (Ibid., p. 75).

No romance, não é claro se a mulher que decepcionou a família do protagonista é a sua própria mãe, porém seu papel de "intrusa necessária" mantém-se no enredo, quando observamos, no capítulo XIX, sua posição diante da discussão dos homens acerca do futuro da propriedade e da família. Assume uma postura de neutralidade em relação aos fatos que assombram o futuro da família. Narrado pela personagem, o capítulo nos mostra que ela tem a consciência de seu caráter de invasora: "Intrusa: a palavra explica muito, se puder entendê-la. Tecedeira dum fio alheio, aparecida por acaso e por necessidade" (Ibid., p. 79). A analogia à imagem da tecedeira mostra que a mãe se apercebe da sua função como procriadora. Ela gera um filho para a manutenção do poder do homem. Ela é necessária para esta função e somente isso. O fio que tece é alheio, pois ela não é da linhagem que ela mesma cria. Será sempre a intrusa. Resigna-se, então, a criar uma nova realidade com seu estojo de pirogravura.

Ainda ligada à imagem da mãe, temos a figura feminina que aparece no capítulo XXXI como uma tentação aos peregrinos. A mulher adentra a floresta nua, "com uma taça de madeira e cristal na mão" (Ibid., p. 129), envolvida em uma espécie de véu. Para diante dos peregrinos, ergue sua taça e bebe dela o líquido da gisandra. Nesse momento, o narrador revela que uma gota do suco para sobre a tatuagem do crucifixo. Seria a mulher misteriosa uma imagem da mãe? Não é possível afirmar essa ideia. Os peregrinos sentemse amedrontados, veem nela uma tentação. Sua figura traz elementos simbólicos, como a taça em que traga o líquido viscoso da gisandra. De uma simbologia extensa, a taça, conforme analisa Chevalier (1986, p. 338), refere-se normalmente às noções de abundância e de imortalidade, podendo ser visto em uma analogia ao seio materno, que produz o leite para alimentar os homens. 
É ainda um símbolo cristão, o célebre graal, cálice no qual Cristo teria tomado vinho na última ceia e que se torna o recipiente onde está seu sangue. A mulher nua na floresta, porém, retoma imagens pagãs de jovens que fazem rituais de celebração à terra e à fertilidade nas florestas. A taça cristã carrega o sangue, que é o princípio da vida (CHEVALIER, 1986, p. 338), mas, na cena de Finisterra, o recipiente está cheio do licor da gisandra, o gérmen da indiferenciação. “Alguém achou minha cruz?", pergunta a mulher aos peregrinos de cabeça de fogo e os convoca a ajudá-la a encontrar a peça. Temendo cair em pecado, os peregrinos gritam, com receio de que, se cometerem um ato carnal, nenhum santo ouviria as suas demandas.

Chevalier observa que o graal também se representa como um símbolo do conhecimento "obtido ao preço da morte no presente", relacionando-se à ideia de renascimento e de imortalidade (1986, p. 339). Nesse contexto, mostra-se interessante pensar que a taça da misteriosa mulher está cheia do líquido da gisandra. Se por um lado podemos fazer uma leitura desse elemento como parte de um ritual à fertilidade, é possível ver, de outro, o prenúncio do fim da propriedade principal, que será tomada pela gelatina produzida pela gisandra, sendo assimilada e levada à indiferenciação. O conteúdo da taça, assim, revela - em um viés fantástico - a morte da propriedade, o fim da família e o renascimento do local tomado pela natureza. O sangue no cálice simboliza a vida; a gisandra suscita o fim da família, o fim da terra como propriedade, finis terra, voltando a um estágio anterior, à natureza. A mulher nua, cuja imagem confunde-se com a da mãe, é vista como sacerdotisa ou cortesã pelos peregrinos, mas pode ser lida como a sacerdotisa que relata o fim da família patriarcal e o retorno ao estado natural.

A cena da mulher misteriosa que convoca os peregrinos à busca de seu crucifixo confunde-se com o desenho fantástico da criança, uma vez que as personagens que caminham em busca de clemência e salvação estão com suas cabeças envoltas por chamas, do mesmo modo que se apresentam na imagem infantil. Misturando-se às características da mãe, a sacerdotisa/cortesã que se mostra como uma tentação aos peregrinos contrasta com a esterilidade presente na paisagem em que se inserem. A chuva que recai sobre o local não permite a fertilidade dos solos, o que leva os habitantes à procura de água para sobreviverem.

A água, no romance, parece diminuir capítulo a capítulo, como indica Eiras (2014, p. 120), o que já se verifica no desenho da criança, no qual a lagoa é apenas uma gota d'água. A sede do protagonista e dos peregrinos apontam para a falta de recursos e para a infertilidade da terra, na qual parece somente proliferar com sucesso a gisandra. A figura 
fantástica da mulher com sua taça repleta do suco licoroso desse elemento suscita, em oposição, a ideia do ritual para a fertilidade do corpo feminino, da intrusa que precisa gerar um descendente para que a família se consolide no futuro. A mãe, que se reconhece como uma invasora dentro do papel no qual é colocada, é a portadora da infertilidade, geradora, possivelmente, do feto que não sobrevive e da criança, único herdeiro que não será capaz de dar continuidade a seu núcleo e perderá a base do poder familiar: a propriedade.

A ideia de fertilidade, constantemente posta em causa ao longo do romance, possibilita uma leitura ampla da relação do protagonista/adulto à descendência ausente e à consequente queda da sua família, simbolizada na perda da casa principal. O termo fértil, de origem latina fertilis, relaciona-se, em uma primeira acepção, à ideia de abundância e fecundidade. $\mathrm{O}$ uso na desinência do caso dativo releva a ideia de algo ou alguém "que se torna fecundo, que fertiliza" 87 . No romance, temos duas pessoas cuja capacidade de ser fecunda, de fertilizar, é questionada ao longo do enredo, a mãe - ou a mulher na história familiar que não cumpre seu papel de gestar e de criar descendência e o próprio adulto, que aparece solitário para ceder ao governo os bens que representam o poder da sua família e das gerações anteriores.

Como citamos, o único elemento que apresenta tal capacidade fecunda parece ser a gisandra, que é, ao mesmo tempo, fértil e abundante. Entretanto, o termo latino fertilis associa-se também, por sentido figurado, à ideia de abundância como riqueza ${ }^{88}$. Em latim, por essa extensão de sentido, as noções de riqueza, fertilidade e prosperidade combinamse. Culminamos, então, na figura do adulto de Finisterra, que não se configura como um fertile pectus ${ }^{89}$, isto é, um "gênio fecundo" "90: não possui descendentes e não possui mais bens e riqueza, dada a sua impotência de recuperar a situação econômica familiar e a entrega de sua propriedade ao Estado. Por fim, fertilis ainda traz o significado de

\footnotetext{
87 Dicionário Latino-Português. (Org.) Ernesto Faria. Distrito Federal: Ministério da Educação e Cultura, 1962.

88 Ibidem.

${ }^{89}$ Expressão utilizada por Ovídio, nas Cartas Pônticas, conjunto de cartas-elegias escritas a amigos e a familiares do autor latino cujo objetivo seria a intervenção junto ao imperador para que ele aceitasse o retorno de Ovídio, que vivia em exílio. No livro 4, na carta II, destinada a Severo, Ovídio utiliza a expressão "fertile pectus" para se referir a seu destinatário como alguém que tem um "coração produtivo" (tradução de productive heart), um espírito fecundo, produtor, pois este oferece alimentos às Divindades e aos Nobres. Cf. Tristia / Ex Ponto. Ovídio. Massachusetts: Harvard University Press, 1939, pp: 424-427. Na versão em português, publicada pela Editora Martins Fontes (2009, trad. Geraldo José Albino), a expressão é traduzida como "espírito fecundo" (p. 119).

90 Dicionário Latino-Português. (Org.) Ernesto Faria. Distrito Federal: Ministério da Educação e Cultura, 1962.
} 
“populoso", fertilis hominum: "país populoso". Temos, neste fim de terra - ou na terra do fim -, o oposto ao território populoso: os peregrinos do passado marcham para longe do local em busca da água e da sobrevivência. A família principal, representada na imagem solitária do protagonista, também parte, não sabemos para onde, mas partem uma vez que perdem seu núcleo, seu poder e sua propriedade. Sob o ponto de vista da fertilidade, da abundância e da prosperidade, Finisterra apresenta-se como uma alegoria do fim do poder territorial dessa possível Gândara que não nos é nomeada. As bases do sistema econômico entram em colapso: acaba-se a família e perde-se o território privado, que será habitat do único elemento que se multiplica neste local quase inóspito: as gisandras.

Nesse âmbito, poderíamos lançar um questionamento que, superficialmente, parece-nos óbvio: seria o fim proclamado em Finisterra a alegoria do sistema econômico vigente durante sua publicação, o capitalismo? Uma leitura dos romances precedentes de Carlos de Oliveira poderia, sim, guiar-nos à interpretação de que o fim de uma família e de sua propriedade, sendo alicerces do sistema capitalista, sugere, assim, um colapso nuclear do sistema burguês. O diálogo do autor com as teorias do Neorrealismo poderia guiar-nos a esse tipo de compreensão, uma vez que outros romances de Oliveira relacionam-se com lutas de classe, exploração das classes oprimidas e a futilidade das classes aristocráticas e burguesas, como se observa em Uma Abelha na Chuva (1953).

A alegoria do fim à qual buscamos demonstrar nossa leitura neste capítulo, entretanto, não indica necessariamente o fim da família central como um indício do fim de um sistema econômico, mas, sim, uma transformação deste diante de forças maiores que o orientam. Sabemos que Oliveira associa-se ainda jovem ao Neorrealismo e que, naturalmente, as teorias dessa estética têm impacto marcante em suas obras, sobretudo naquelas antes do exímio exercício da revisão e da reescritura. Em seu ensaio "A Condição da Arte", o autor expressa que a raiz da literatura seria a solidariedade, colocada à disposição e à compreensão tanto do homem comum como "à nossa própria" (1945, s/p). Essa visão nos permitiu uma leitura profícua de Casa na Duna e de Pequenos Burgueses, mas ela nos auxiliaria a entender de que modo Finisterra configura-se como uma alegoria do fim?

Diante do evidente diálogo entre Casa na Duna e Finisterra, analisado por diversos críticos, gostaríamos de indicar que o fim solitário do protagonista/adulto e a iminente perda de sua propriedade sugerem mais uma alegoria de transformação de um sistema econômico do que propriamente de seu fim. Já em Casa na Duna observamos um processo similar àquele que decorre no último romance no que tange à noção de 
transformação de um sistema vigente. Como visto, Mariano Paulo detinha o poder econômico em sua quinta, vivia de regime geracional da exploração da terra e de seus moradores e via com tristeza que seu filho, Hilário, não poderia seguir esse movimento para manter o domínio que tinham sobre a aldeia de Corrocovo. Entretanto, face às intempéries da natureza e ao próprio desenvolvimento local a partir de novos meios de transporte, o modus operandi no qual assentava o seu poder sofre um abalo irreversível.

O que vemos, pois, não é o fim de um sistema econômico propriamente dito. Há um processo natural dos sistemas socioeconômicos de transformação quando a sociedade em questão atinge um determinado grau de desenvolvimento que a impulsiona a criar novas instituições, conforme observa Marx em obras como O Capital (2011), Manuscritos Econômicos-Filosóficos (2017) e, em conjunto com Engels, O Manifesto Comunista (2005). O sistema concentrado nas mãos do poder rural local cede espaço para uma dinâmica de maior produtividade e circulação de mercadorias com a intensificação da industrialização e do crescimento da infraestrutura. Assim, a economia agrícola de regiões até então isoladas é suplantada por um sistema de maior concorrência, agilidade e de maior produção. O que observamos é, portanto, a transformação do próprio sistema capitalista, que suprime pequenos produtores para dar espaço a maiores e mais competitivas indústrias.

Tal processo é aprofundado aos olhos do leitor em Casa na Duna, porém em Finisterra não temos a exata noção do que leva a família central ao colapso e à perda de sua propriedade. Pode-se depreender, no entanto, que a atividade desse núcleo anteriormente ao declínio econômico era distinta da atividade industrial, pois é justamente esse setor que surge, na visão do tio, como um instrumento salvador das condições da família quando ele sugere sua sonhada fábrica de porcelanas. Estamos diante possivelmente de um conflito entre a agricultura e a indústria, de modo análogo ao que ocorre em Corrocovo com a família de Mariano Paulo. Ambas as famílias parecem passar pela dinâmica de transformação de uma sociedade pautada na economia local e agrícola para outra baseada em produtos industrializados, maior circulação de produtos e, consequentemente, maior competitividade entre os fornecedores e produtores. Carlos de Oliveira nos indica, dessa maneira, como o próprio sistema capitalista, em seu mecanismo de desenvolvimento, que parece devorar metaforicamente os pequenos produtores locais, anteriormente em ascensão e no poder, para estabelecer suas novas bases mais tecnológicas e competitivas. 
Apesar das semelhanças entre as narrativas do primeiro e do último romance de Oliveira, temos neste a presença de um elemento que não é trabalhado naquele: o Estado. No enredo, temos a presença do executor fiscal, um funcionário que pode estar ligado a um banco ou ao próprio Estado, cuja função é tomar a propriedade da família que se endividou a ponto de não poder cumprir com seus compromissos econômicos. A hipoteca, como observa Engels (s/d, p. 221), é introduzida em sociedades antigas, como em Atenas, assim que se institui a propriedade privada. Sua execução pressupõe consequências contrárias: de um lado, há o possuidor do bem a ser tomado que se encontra em estado de endividamento e insucesso econômico; de outro, há instituições financeiras e o Estado ele mesmo que absorvem a propriedade e fortalecem-se no âmbito do capital. Ao inserir a perda da casa pela execução da hipoteca, Oliveira não indica um fracasso do sistema capitalista especificamente, mas, sim o seu fortalecimento em detrimento tanto do trabalhador (que está pressuposto numa propriedade agrícola) quando do próprio capitalista rural local.

Com a ampliação de mercados e a conexão entre eles, aumenta-se, naturalmente, a procura por mercadorias, conforme explicam Marx e Engels (2005, p. 41), processo que não é exclusivo do final do século XIX para o início do XX, é algo muito anterior verificado na passagem da sociedade feudal para a sociedade burguesa. Não cabe no escopo do presente trabalho aprofundar tais questões teóricas, porém nota-se que o sistema capitalista desenvolve-se constantemente, e o Estado e instituições privadas crescem, mesmo que haja o fracasso econômico de um produtor agrícola local. Nas análises de Marx presentes no Manifesto Comunista (2005) e em O Capital (2011), verifica-se que o sistema capitalista está em uma "revolução ininterrupta dos meios de produção, sobretudo dos instrumentos de produção" (ALTHUSSER, in: MARX, 2011, p. 68), isto é, uma constante transformação ligada ao desenvolvimento tecnológico. É justamente tal temática de mudanças bruscas na sociedade que acompanhamos na leitura de Casa na Duna e, posteriormente, no viés abordado do último romance. Nesse sentido, podemos depreender um olhar crítico de Oliveira presente em Finisterra que ainda dialoga com as ideias de sua fase anterior mais próxima da tendência neorrealista. $\mathrm{O}$ autor aponta um aspecto importante a partir da personagem do executor fiscal: o modo de produção vigente naquela terra (talvez a Gândara, como se sugere) e naquela sociedade é devorador, o que Marx já aponta em suas análises n'O Capital (2011, p. 962).

É importante notar que o Estado não surge como um poder que se impõe à sociedade "de fora para dentro", como analisa Engels (s/d, p. 225), mas antes é "um 
produto da sociedade, quando esta chega a um determinado grau de desenvolvimento" (Ibid.). É o resultado de sociedades que se dividem em antagonismos ligados ao surgimento das classes. Nas palavras de Engels (Ibid.):

\begin{abstract}
Mas para que esses antagonismos, essas classes com interesses econômicos colidentes não se devorem e não se consumam a sociedade numa luta estéril, torna-se necessário um poder colocado aparentemente por cima da sociedade, chamado a amortecer o choque e mantê-lo dentro dos limites da "ordem". Este poder, nascido da sociedade, mas posto acima dela e distanciando-se cada vez mais, é o Estado.
\end{abstract}

Assim, observa-se que a força estatal é também fruto do desenvolvimento das sociedades em diferentes classes, resultando de um combate constante entre um grupo economicamente dominante e outro oprimido.

Considerando-se que o Estado surge da necessidade de se controlar o antagonismos de classe, ao mesmo tempo em que nasce deste conflito, Engels observa que, por regra geral, "o Estado da classe mais poderosa, da classe economicamente dominante, classe que, por intermédio dele, se converte também em classe politicamente dominante e adquire novos meios para a repressão e exploração da classe oprimida" (s/d, p. 228). É nesse sentido que se observam nos Estados históricos direitos concedidos de acordo com as posses de cada cidadão, tornando-se uma força de proteção àqueles que possuem bens. Ainda que as sociedades tenham se desenvolvido e o sistema econômico também em diversas formas, na estrutura capitalista ainda se mantém um Estado que visa à proteção do capital como um todo. Em seu crescimento como instituição, já estava presente nas concepções estatais a propriedade privada e a hipoteca, as quais dialogam com outros dois elementos importantes: a cobrança de impostos e a introdução das noções de juros e usura.

De volta para o contexto de Finisterra, observa-se a relação entre a propriedade privada e a cobrança de impostos ou juros, elementos que normalmente são os fatores de perda de bens hipotecados. No livro, não há claramente indícios de que o executor fiscal seja representante de um banco ou do próprio Estado, mas se sabe que a tomada da casa central representa a incapacidade financeira daquele núcleo familiar diante de seus compromissos com ambas as instituições. A perda do local demonstra-se, assim, como o fortalecimento do capital - enquanto relação social - e do sistema vigente, que se retroalimenta do fracasso econômico daquele que outrora fora da classe dominante.

O único elemento que parece prosperar neste sistema é a gisandra, que se reproduz e absorve tudo a sua volta. Poderíamos pensar, por um momento, que tal vegetal-mineral- 
animal, pois ela é um amálgama dos reinos naturais, significaria o retorno ao estado natural, primitivo e anterior às noções de capital, exploração, economia. Entretanto, ela é elaborada no texto quase como uma personagem que ronda a propriedade, ameaçando-a de invasão, assimilação e indiferenciação. Sua imagem é mais assustadora do que confortante, o que sugere uma espécie de metáfora do próprio sistema vigente, no qual o todo assimila as pequenas partes que fracassam e que estão sujeitas ao seu poder econômico e tudo indiferencia: as experiências individuais são oprimidas e devoradas pela necessidade de fortalecimento do todo: o capital.

Nesse sentido, Oliveira apresenta uma crítica fortemente ligada às ideias defendidas por Marx na sua obra $O$ Capital: para esse sistema, pouco importa se uma pessoa perde o emprego, se uma loja específica vai à falência ou se um produtor local não pode mais arcar com sua produção agrícola. A perda de uma família não significa nada para o sistema, desde que se esteja no domínio das relações do capital como um todo. A alegoria da transformação do sistema vigente que indicamos como leitura de Finisterra aponta para ideias que Marx desenvolve na sua obra principal: a perda de uma propriedade não é significativa para o capitalismo, que se transforma e reestrutura impondo a perda humana. O executor fiscal, como representante do Estado, é aquele que põe em prática as leis que protegem a valorização do capital.

Com a hipoteca, a família do protagonista perde tudo, seus bens, sua história, suas experiências e suas memórias. É justamente dessa imensa perda humana que falam as constantes representações da casa pelas personagens. O adulto, talvez em um último gesto de manter essas lembranças, constrói sua maquete com medidas que ele conhece de cor. Essa vivência humana e particular é devorada por um sistema político-econômico que valoriza o capital, e não os indivíduos. Essa crítica percorre os ensaios marxianos, como se observa no Manifesto Comunista (cf. p. 44): o sistema capitalista impõe-se à sociedade gerando perdas humanas, mas fortalecendo a principal relação social: o capital. O Estado, como executor dessa relação, reforça-se, e a família submete-se à perda completa: a casa, o poder econômico, as memórias e as experiências. Nossa leitura, portanto, indica a perda como alegoria da transformação constante do sistema capitalista que se retroalimenta e se autofortalece a partir da exploração e das perdas humanas, seja de trabalhadores assalariados, seja de proprietários locais que não podem competir com as inovações vividas pelo desenvolvimento socioeconômico.

Dessa forma, procuramos ressaltar neste capítulo que Finisterra é, de fato, um livro que se diferencia da obra considerada neorrealista de Carlos de Oliveira em diversos 
aspectos analisados. Sua linguagem inova, apresentando uma escrita em que se misturam a prosa e a poesia, seu gênero é fluido, transitando desde o romance, passando pela poesia, até a metaficção. Tal inovação, porém, coaduna-se à crítica social abordada sobre o colapso do sistema patriarcal e a transformação que autoalimenta o sistema capitalista. Como cita Barthes (2004, p. 22), ao "mudar a língua" - uma expressão mallarmeana Oliveira faz, concomitantemente, o "mudar o mundo" - termo verificado na teoria marxiana. Há nessa união o deslocamento da linguagem, um aspecto político da escrita. Romper com a linguagem presente nos romances anteriores, que carregavam um certo caráter pedagógico acerca da crítica social engendrada, revela um processo, analisado por Barthes (2004, p. 22) de contestação da ética da linguagem literária. O teimar de Oliveira desenvolve-se durante o mecanismo de deslocamento de uma linguagem gregária, presente nos discursos tipificados que cercam parte da escrita neorrealista. Se o movimento propunha uma linguagem clara e objetiva, pedagogicamente elaborada para se chamar atenção aos problemas socioeconômicos que eram a base da sua produção, o Neorrealismo, por vezes, mantinha-se dentro e submetido ao poder da língua, que faz na sua aplicação codificada, estruturada e classificada, um produto gregário, nas palavras barthesianas (Ibid., p. 25). É dessa linguagem que falamos em Casa na Duna e Pequenos Burgueses, romances em que os conflitos de classe e as questões socioeconômicas ganhavam, em certos momentos, uma perspectiva quase maniqueísta, entre os pobres de bem e os ricos malignos.

Finisterra, porém, surge como um deslocamento total da perspectiva mais didatizante comum a certos romances neorrealistas e promove, por meio da sua inovação linguística, uma inovação também no que tange à temática abordada. Se o poder está presente "nos mais finos mecanismos do intercâmbio social", como observa Barthes, desde a organização da sociedade em grupos e em classes até a as opiniões correntes, a moda, as relações familiares, Oliveira rompe dupla e concomitantemente com o mecanismo onde o poder se instaura: a linguagem e as bases da sociedade capitalista. Se a língua é uma expressão obrigatória e classificatória, em Finisterra, vemos o deslocamento desse código, seu questionamento, sua flexibilidade, sua fluência e seu caráter poético. Estamos diante da poesia ou da prosa? Não sabemos. E não importa ter uma resposta única a essa questão. O que se destaca é o processo constante de deslocarse entre os gêneros, de criar signos, imagens e significações para a linguagem literária, um procedimento que visa, desde as primeiras páginas, questionar o discurso tipificado o qual o leitor poderia esperar talvez. Mas não. Nesta obra, tudo ganha fluência e 
transforma-se: a língua, os limites do gênero, a estrutura literária e, claro, o seu conteúdo. A transformação capitalista, a derrocada da base desse sistema e a sua retroalimentação despontam concomitantemente a um exercício constante de questionar a linguagem, deslocá-la, recriá-la e recolocá-la em posições que afirmam, usando uma expressão de Barthes, o irredutível da literatura, o seu processo de dar conta do real por meio da língua e, ao mesmo tempo, elaborá-la de um modo em que se "tenta escapar ao seu próprio poder e à sua própria servidão" (BARTHES, 2004, p. 26).

No último romance de Oliveira, sua crítica ao sistema socioeconômico não esvanece, pelo contrário, ela se multiplica em leituras distintas que nos permitiram apontar uma relação com as ideias críticas pautadas no marxismo que conduziram o início do processo artístico do autor. Ademais, fortalece-se diante de uma postura crítica e política por meio do trabalho com a linguagem. Não queremos afirmar que este romance é um exemplo do Neorrealismo, mas tentamos demonstrar que alguns ideais neorrealistas não se afastaram completamente do projeto poético e ficcional de Oliveira. Sua visão aguçada sobre as relações de classe e sobre o sistema econômico vigente dialoga com a interpretação das experiências humanas.

Há, no entanto, que se destacar de forma enfática que a linguagem presente na obra rompe com aquela dos romances anteriores e ganha, por si só, uma posição política de combate ao poder gregário das línguas. Se o poder está na linguagem (BARTHES, 2004, p. 25), apossando-se dela para fazer um produto através do qual se instaura, Oliveira está a deslocar-se a todo momento desse mecanismo, contestando tal poder em sua estrutura e em sua temática. Aquilo que fora vivido nas aldeias rurais da Gândara marcou e acompanhou o percurso da escrita de Oliveira, mas, ao longo do exímio trabalho de revisões e reescritas, tais experiências fortaleceram-se diante de uma linguagem que, ela própria, transforma-se em um questionamento do poder ao qual a sociedade portuguesa estava submetida. 


\section{A prosa de Sophia de Mello Breyner Andresen}

Em um inquérito respondido por diversos artistas sobre questões ligadas à arte e à escrita, Sophia de Mello Breyner Andresen diz: "Um poema não faz parte de uma literatura, mas sim do mundo que estamos" (In: DIONÍSIO; FARIA; MATOS, p. 227). Essa afirmação parece iluminar perfeitamente a lírica da autora, entretanto é também muito elucidativa no que diz respeito aos seus contos. Marcados por uma peculiar visão que contempla uma ligação entre o homem e o mundo em que se insere, a prosa da autora, "poeta em tudo que escreve" (COELHO, 1970, p. 78), alçou um lugar de importância na sua obra literária como também na literatura portuguesa contemporânea.

A ligação entre a literatura e a realidade faz-nos lembrar de algumas concepções de Georg Lukács em seus primeiros trabalhos, como observa Nicolas Tertulian: "A convicção de que a grande arte é sempre inspirada pelo sentimento de uma possível harmonia entre a interioridade e a exterioridade, entre a alma e o destino, entre as aspirações e a realidade do mundo objetivo" (1980, p. 53, tradução nossa). Na "grande arte", haveria, assim, uma conexão, uma comunhão, entre o que é próprio do indivíduo e o que lhe rodeia. Essa ideia nos leva em direção a uma definição que a autora apresenta: “o poema é o selo da aliança do homem com as coisas" (1960, p. 54). Podemos considerar essa perspectiva também na sua obra ficcional, que se define por uma ligação entre o ser e sua realidade.

Reconhecida por seus contos infantis, Sophia Andresen lança em 1962 a primeira edição de seus Contos Exemplares, reunião de sete contos de extensões distintas que parece ilustrar o seu seguinte verso: "O meu interior é uma atenção voltada para fora" (2011, p. 525). Em enredos distintos, as narrativas parecem nos colocar diante da atenção ao mundo de que Sophia Andresen tanto nos fala, mostrando-se atenta à maneira como o homem se relaciona com seus semelhantes. Revela, assim, uma ligação entre poesia e ação social, como observa Jacinto Prado Coelho, o que seria uma característica de "modos indissolúveis duma vocação a que [a autora] obedece, com um sentido religioso do dever" (1970, p. 78).

Lançado no mesmo ano que Livro Sexto, a obra de poesia considerada pela crítica como a mais política da autora, Contos Exemplares também procura exprimir aspectos sociopolíticos em grande parte de suas sete narrativas. Desde o título, temos contato com

\footnotetext{
${ }^{91}$ Verso de "Poema", publicado no livro Geografia, de 1967.
} 
a noção de literatura em função exemplar, como observa Clara Rocha (1980, p. 11). E, de fato, cada um dos contos sugere um "exemplo" da mundividência que Sophia Andresen imprime em sua obra poética e ficcional. Para Jacinto Prado Coelho, os contos são exemplares "porque destilam, sob forma alegórica, uma profunda visão da vida, uma sabedoria" (1970, p. 78), o que dialoga com a opção da autora em trazer como epígrafe do volume o prólogo ao leitor das Novelas Ejemplares, de Cervantes: "Heles dado el nombre ejemplares, y si bien lo miras no hay ninguna de quien no se pueda sacar um ejemplo" (2010, p. 09).

Naturalmente, podemos refletir, em um primeiro momento, sobre o adjetivo “exemplar" a partir da ideia de "exemplo". Susan Suleiman verifica que a ideia de fícções exemplares tem origem na noção de exemplum, clássica figura de retórica. Esse termo no grego paradeigma - "designava persuasão pela indução ou argumento por analogia" (1993, p. 27, tradução nossa), opondo-se ao termo enthymeme, que pressupunha a persuasão pela dedução. Assim, um exemplum era oferecido pelo orador ao público, configurando-se, geralmente, por uma comparação ou por uma alusão a fatos históricos, para que, então, o orador conseguisse delinear conclusões em seu discurso. Aristóteles, ainda segundo Suleiman, teria separado os exempla em "reais" e "ficcionais". Aquele seria proveniente da história ou da mitologia; este viria de criações do orador. Nesse aspecto, Aristóteles observou as fábulas como um conjunto de ações que permitem ao autor delinear uma "moral" por meio de exemplos concretos.

Pensando sobre esses aspectos, os Contos Exemplares trazem um aspecto real em um discurso ficcional, afinal a autora afirma a relação da sua escrita com a realidade e diz: "Para mim, é muito difícil separar uma ética de uma poética. Ética e Poética, ambas são a busca de uma relação justa com o real" (ANDRESEN, 1985, p. 03). Se buscarmos a separação dos exempla feita por Aristóteles, teríamos de considerar que o exemplo ficcional - a criação - está imbricada no real, não sendo assim, aos olhos de Sophia, possível separar a escrita do mundo em que se insere. Para ela, "o real é aquilo que emerge e se manifesta, é tudo aquilo que se manifesta e eu posso apreender" (Ibid.). A sua escrita é um dos modos de apreensão, por isso seus textos "exemplares" não podem separar o ficcional do real.

Os Contos Exemplares são, frequentemente, assinalados como parábolas pelos críticos - em oposição às Histórias da Terra e do Mar, de 1984, em que alguns contos são vistos como híbridos de fábulas e contos de fadas. Rocha (2001) observa o caráter parabólico nos contos "A Viagem", "O Homem” e "o Jantar do Bispo", e o termo, por 
sua definição, comporta o discurso dos contos, afinal o gênero constitui-se como uma narrativa, geralmente alegórica, que transmite uma mensagem indireta apreendida por meio de exemplos e analogias. Suleiman analisa que a parábola - e textos tidos como “exemplares" - pressupõe a interpretação, trazendo, usualmente, "um significado outro ou maior que a mensagem imediata" (1993, p. 30, tradução nossa) e diz

\begin{abstract}
A interpretação torna explícita ou "descobre" o significado, o qual estava na história, mas ocultado. A relação entre história e interpretação é então hierárquica, pelo caráter lógico e em termos de valor: a interpretação é "superior" à história, como o geral é ao particular, o universal ao singular ou a verdade é à sua manifestação. É ainda superior em outro sentido: estrategicamente, como se fosse: a interpretação comanda a história assim como o final comanda o significado ou uma estratégia comanda a tática. Em suma, a narrativa em uma parábola existe somente para dar origem a uma interpretação (Ibid., pp 30-31).
\end{abstract}

Em tal relação história-interpretação, revela-se o caráter exemplar, o que oferece um embasamento aos críticos para afirmarem o caráter parabólico desses contos. No livro, essa perspectiva ganha uma significação maior se considerarmos o forte diálogo com aspectos do cristianismo trazidos por Sophia aos textos.

Para Rocha, o viés exemplar pode ser também uma aproximação da autora com valores do pensamento medieval, pois a autora "parece enraizar-se na prática medieval duma literatura exemplar, lembrando mutatis mutandis, as Vidas de Santos e toda uma escrita orientada no sentido de servir como exemplo para os outros homens" (1980, p. 11). Ainda para a crítica, o uso da alegoria como símbolo, aspecto fortemente elaborado nos contos, é um modo altamente recorrente nas artes e na literatura da primeira metade da Idade Média (Ibid.). “Em Sophia, o símbolo parece ser dotado de uma função que o aproxima da prática simbólica medieval: as marcas simbolizantes reenviam a uma transcendência universal desconhecida e misteriosa [...] (Ibid.). A natureza simbolizante de parte das narrativas fortalece a noção de "exemplo", de algo que deve ser modelo para os indivíduos.

A acepção do termo "exemplo" carrega ainda o sentido de "algo que pode servir de lição" "92, e os contos andresenianos apresentados nesse volume parecem também dialogar com essa acepção, pois promovem reflexões sobre aspectos sociais que envolvem a vida do homem, incluindo a relação que este tem com seus semelhantes. No conto "O Jantar do Bispo", por exemplo, vemos uma crítica, a partir de alegorias do bem

\footnotetext{
92 Verbete "exemplo". In: Dicionário Eletrônico Houaiss.
} 
e do mal, que envolve as relações de classe dentro de uma comunidade, o que será explorado a seguir. Já em "O Homem", o leitor depara-se diante da miséria e da privação simbolizada na imagem de um indivíduo muito pobre. Em "O Retrato de Mónica”, por sua vez, temos um conto satírico - um diferencial entre as outras narrativas - que pode ser lido à luz do contexto sociopolítico em que se insere o livro: o Estado Novo, liderado por Salazar. Assim, as narrativas exemplares também suscitam mensagens em torno de elementos políticos, indicando a concepção política da própria escritora.

Como marca da lírica andreseniana, também observamos nos Contos Exemplares um diálogo com a cultura helênica, exercendo uma influência no modo como a escritora elabora sua visão de mundo em torno de elementos sociais. Nesse contexto, a ideia de “justiça” está presente nas narrativas, retomando a noção expressa no primeiro verso do poema "Catarina Eufémia": "O primeiro tema da reflexão grega é a justiça". Rocha observa que em alguns contos "é evidente a omnipresença deste valor eufórico, embora por vezes encoberta pela sucessão de situações disfóricas" (1980, p. 10). Assim, valores como o equilíbrio, a harmonia, a democracia e a justiça são significativamente elaborados nos textos e indicam uma concepção de poesia que vai muito além da literatura.

Do mesmo modo que Carlos de Oliveira estabeleceu-se em desvio de um Neorrealismo mais ortodoxo, também vemos em Sophia Andresen a singularidade e liberdade de seu projeto poético. Rocha faz uma leitura desse aspecto a partir de sua filiação aos Cadernos de Poesia, com os quais colabora, em 1940, juntamente com Jorge de Sena e José Blanc de Portugal. O lema “A Poesia é só Uma!" aponta para uma liberdade e imparcialidade no que diz respeito a escolas literárias ou tendências artísticas, como observa Luís Adriano Carlos, o que atinge a obra andreseniana ao longo de sua trajetória segundo Rocha:

Sophia procurou e soube sempre manter, ao longo de sua produção literária, essa posição inicial de independência relativamente a escolas e de originalidade criadora e estilística. Tal acontece nos Contos Exemplares, onde é notória a fidelidade aos valores do individualismo criador, de qualidade estética e de originalidade apregoados pelos Cadernos de Poesia e em que a escrita, norteada por estes princípios, se reveste por vezes de um certo hermetismo (1980, p. 13).

Tal hermetismo parece contrastar com a linguagem objetiva e límpida trazida por Sophia em suas obras, como observa Eduardo Prado Coelho (1980, p. 20), ou como seu pai afirmou "uma linguagem calma, fresca, límpida, feita para exprimir a doçura e a pureza das coisas naturais, em contraste com o excessivo [...]" (1970, p 78), sendo uma "exigente nomeadora das aparências do mundo visível ou de ordem-desordem humana", 
nas palavras de Eduardo Lourenço (In: ANDRESEN, 1975, p. II), o que a coloca em um lugar distinto no campo literário português:

[...] o nome de Sophia aparece associado às mudanças poéticas verificadas em Portugal nos anos 50: soberania da palavra poética, exigência de uma palavra pura e justa, vinculação da justeza do poema à justiça na cidade, retorno de uma infinita exigência de sacralidade expansiva (CARLOS, 2002, p. 237).

A linguagem clara e objetiva aproxima-se da palavra pura e justa, unindo-se à justeza do texto, buscando-se a forma justa.

Essas demandas, vistas por Maria de Lourdes Belchior (1986, p. 36) como uma procura pela pureza e harmonia, suscitam também a noções de ordem, e a justeza liga-se à ideia de justiça, algo essencial à escrita andreseniana. Manuel Gusmão, em seu ensaio "Da evidência poética: justeza e justiça na poesia de Sophia", relaciona ambos os conceitos, verificando que a perspectiva "justa" nessa escrita é um viés político que não obedece ao "calor do momento", mas é parte do percurso literário da autora:

É certo que essa politicidade se torna particularmente insistente em tempos de paixão ou urgência históricas, como acontece com outros poetas de várias e desencontradas linhagens. Isso significa apenas, aqui e para já, que esta poesia responde às suas circunstâncias, mas convém notar que essa resposta não releva de um qualquer automatismo, não obedece nem lisonjeia uma qualquer doxa, ou seja não é demagógica: ela sabe que tem de encontrar a sua própria linguagem, o seu registro certo e o rigor da imaginação, ou seja a forma que lhe seja justa. (2010, p. 38).

Em seu mundo peculiar, a autora exige a justeza, o equilíbrio, o que a coloca diante da procura inevitável da justiça no mundo.

Esse conceito "se confunde com aquele equilíbrio das coisas", como ela nos diz em sua “Arte Poética III" (2011, p. 842), e não é somente pela poesia que ela vai empenhar sua busca. Seus Contos Exemplares navegam entre a justiça e a injustiça, entre a ordem e a desordem a partir da denúncia do desequilíbrio, nomeando o terror, a desigualdade, a exploração e o abandono praticados por homens contra seus próprios semelhantes. Para utilizarmos um termo da autora, seus contos indicam a aliança quebrada, a fissura na totalidade que procura em seus textos. Na obra, a desarmonia é ilustrada em um combate entre a riqueza e a pobreza, uma tensão entre o bem e o mal pautada em ambição, cobiça, desprezo e desumanidade. É, de certa forma, um conflito entre o que aproxima o homem de sua existência - expressa pelo viés da pobreza - e o que o distancia: o poder. 
Tal aspecto é bem trabalhado em três narrativas: "O Jantar do Bispo", "O Homem" e "O Retrato de Mónica". Cada qual a sua maneira, esses contos procuram mostrar sob um caráter negativo a influência do capital sobre os homens, os jogos de interesse que tecem a sociedade e as consequências às quais pessoas alijadas de poder estão subjugadas. No primeiro enredo, temos ilustrado o conflito entre a pobreza e a riqueza, conceitos que serão explorados por personagens alegóricas, trazendo o bem e o mal para a trama. Dessa maneira, selecionaremos tal história para a análise da questão social e da relação entre classes nessa obra de Sophia Andresen.

Os Contos Exemplares expressam uma reflexão sobre aspectos da sociedade portuguesa do seu contexto, marcada pela opressão do Estado Novo e por seu abandono em relação às camadas mais desfavorecidas, o que vemos presente nos temas nucleares da obra. Em dois grupos, Clara Rocha procura sistematizá-los: de um lado, inclui-se a justiça, a poesia, a criação poética, a natureza e as relações dos homens com seus semelhantes. Há também a ligação com a morte, o tempo, o mistério e o divino. O tema do antigo e do instante, por exemplo, exprimem o diálogo andreseniano com os elementos clássicos. Em um outro grupo, unem-se temas como a espera e a promessa messiânica (ou sebastianista), correspondendo à ideia de desejo (1980, p. 30, grifo da autora).

Tais temáticas se organizam, de certa forma, na expressão de uma consciência sobre o cenário social no qual a poeta está inserida, o que é notado na dedicatória do livro: "Para o Francisco, que me ensinou a coragem e a alegria do combate desigual", expressão que se refere a uma obra ${ }^{93}$ de seu marido, Francisco de Sousa Tavares. Em algumas entrevistas, a autora ressalta que a convivência com ele promoveu o contato com diversos aspectos sociopolíticos que influenciaram sua percepção sobre a realidade. Conforme afirma Rocha, a conscientização sobre aspectos politizados leva a uma "desmistificação da ideologia dominante" do período em que escreve. Além disso,

A autora empresta aos conteúdos sociais e éticos da sua obra a mundividência humanista cristã, presente sobretudo nos contos que focam os problemas da injustiça e da desigualdade, como "O Jantar do Bispo", "O Homem" e "Os Três Reis do Oriente". Tal mundividência prende-se com a formação religiosa de Sophia e também, como facilmente se supõe, com as noções clássicas de harmonia e equilíbrio (1980, p. 15).

\footnotetext{
${ }^{93}$ Combate Desigual: ensaios de sociologia portuguesa é um livro de ensaios publicado em 1960, no Porto, pela Tipografia Primavera, que traz ensaios críticos sobre questões políticas e sociais.
} 
Assim, há uma espécie de fusão entre a visão de mundo da autora e a sua percepção sobre os problemas sociais que estavam em seu entorno, o que faz desses contos uma forma de combate e de denúncia.

O segundo objeto da nossa análise é parte de outro livro de contos da autora, Histórias da Terra e do Mar, publicado pela primeira vez em 1984. Muito bem recebido pela crítica, esse volume reiterou o reconhecimento da autora também no campo da ficção, caminho aberto pelos textos infantis e Contos Exemplares, trazendo novamente enredos imbuídos de uma intensa carga poética. Em sua recensão, Maria Alzira Aleixo ressalta que Sophia veicula nessa obra "temáticas que confinam com uma ordem de relacionamento imediato (embora talvez não directo) do homem com as coisas e com o mundo" (1985, p. 92), característica preponderante do seu projeto poético. De leitura aparentemente simples, essas micro-histórias expressam-se pelo já conhecido léxico objetivo e límpido típicos dos textos andresenianos, aproximando o leitor do objeto narrado com mensagens "reconhecíveis e elementares" (Ibid., p. 93).

Os cinco contos dessa obra trazem, segundo Aleixo, apenas uma aparência simples, pois se complexificam em múltiplos eixos de elementos semânticos estabelecidos pelos temas elaborados, já recorrentes na obra poética e ficcional da autora (Ibid.). A casa, por exemplo, é uma imagem central e é explorada de diversas formas; desde sua concepção física e concreta até a noção de fator de subjetividade de personagens, como ocorre nos enredos de "O silêncio" e "A Casa do Mar". Esse tema também é desenvolvido através da noção de religação entre o homem e os elementos do mundo, tão presente na lírica de Sophia; ocorre, porém, uma abordagem pelo viés negativo, isto é, pela impossibilidade de conexão entre esses elementos, indicando uma espécie de falta entre o ser e o seu lugar, como se explora no conto "A Saga", no qual o protagonista nunca pode retornar à casa original, à residência e à cidade de seus pais. De forte simbologia, a casa surge como o centro, o local que abriga a ordem, suscitando o equilíbrio desejado por essa prosa. Temos, desse modo, o aspecto da "terra" de onde surgem as histórias que nos são contadas.

A "terra" suscitada pelo título liga-se ao "mar", cenário central dos contos "A Saga" e "A Casa do Mar". Em princípio, poderíamos pensar que ambas as imagens surgiriam como oposição. Porém, não é dessa forma que Sophia Andresen as articula nesse livro. Elas aparecem conectadas, em extensão uma à outra. Nessa ligação, todos os elementos que nascem em tal espaço parecem estar em uma relação consubstancial, em harmonia. Em "A Casa do Mar", por exemplo, entre o mar e a casa em questão estão as 
dunas, descritas como "um grande jardim deserto, inculto e transparente, onde o vento, que curva as ervas altas, secas e final, faz voar em frente dos olhos o loiro dos cabelos" (ANDRESEN, 2017, p 45), em um equilíbrio entre o ser e a natureza. A casa ergue-se, mas não rompe com o mar nessa paisagem:

Dentro de casa, o mar ressoa como no interior de um búzio. Quando abro as gavetas, a minha roupa cheira a maresia, como um molho de algas. Profundos, os espelhos refletem demoradamente os dias. E em frente das janelas, o mar brilha como inumeráveis espelhos quebrados. [...] O chão é esfregado, as paredes caiadas. Em todas as coisas está inscrita uma limpeza de sal. A exaltação marinha habita o ar (Ibid.).

A casa e o mar fundem-se no cenário, visto pelo leitor através da concretude dessa descrição. A limpeza da casa remete à transparência das dunas e ao sal do mar. Esse simples e, ao mesmo tempo, complexo quadro é apreendido pelo leitor e, concomitantemente, revela a busca pela apreensão do real por meio da narrativa - um propósito recorrente da obra andreseniana. Em "A Saga", a terra e o mar unem-se por meio da subjetividade da personagem principal, Hans. Sua conexão com sua terra de origem estende-se na sua paixão pelo oceano e pela navegação. Assim, não podendo retornar a seu lugar inicial, o mar torna-se o seu local e a sua casa. Hans é, assim, movido subjetivamente pelo desejo de retorno à terra de nascimento e pelo anseio de desbravar os mares, complementando um no outro. Desse modo, as micronarrativas não são histórias da terra "ou" do mar. E sim da terra e do mar em sua ligação.

Em tal panorama de harmonia, qualquer fissura ou ruptura surge de forma intensificada e promove uma reflexão sobre o desejo - e a possibilidade - de união entre o homem e sua realidade. "A Saga", como vimos, apresenta objetivamente na narrativa do nórdico Hans a impossibilidade de se voltar às origens, ao "dia inicial", imagem frequente da escrita de Sophia Andresen. Ou ainda em "O Silêncio", no qual a personagem tem a ordem e a harmonia de sua casa corrompidas por um grito no meio na noite, trazendo um alheamento dela diante do seu espaço, um descolamento do ser em relação a seu lugar, como observa Aleixo (1985, p. 93). A conexão entre o homem e o mundo é problematizada nos contos, sendo um anseio e uma busca, mas surge também explorada pelo viés de impossibilidade de concretização.

Nesse contexto, temos o conto "A Gata Borralheira", considerado por Aleixo o mais curioso dentre os cinco (1985, p. 93). Na atualização do famoso conto de fadas, nossa Cinderela surge em um tom crítico, e a moral da história infantil recria-se em uma perspectiva de análise política. Lúcia, uma jovem moça, vê-se em situação humilhante 
quando vai a um baile e não tem sapatos apropriados para a ocasião, sendo obrigada a calçar um par velho e estragado, de aparência pobre. Esse sentimento torna-se a força motriz para o desejo de ascensão social, e Sophia Andresen vai buscar justamente nisso uma reflexão crítica sobre a relação entre classes na sociedade. Em seguida, propomos a análise dos contos "O Retrato de Mónica" e "O Homem” com o objetivo de verificarmos de que maneira a riqueza e a pobreza são descritas pela autora tendo como base valores importantes ao seu projeto poético como os ideais cristãos e a justiça. Por tal razão, escolhemos as micronarrativas para complementar nossa análise sobre as questões sociais na obra ficcional andreseniana, buscando estabelecer entre os contos uma reflexão sobre o modo como tal temática se insere no projeto poético andreseniano.

\subsection{A concepção social andreseniana: o cristianismo em "O Jantar do Bispo"}

No ensaio "Poesia e Revolução", publicado cerca de quinze anos após seus Contos Exemplares, Sophia elabora a ideia de que a poesia "é a mais funda implicação do homem no real", sendo por isso "necessariamente política e fundamento da política" (1977, p. 77). Assim, o poeta é, segundo a autora, levado a buscar a justa relação entre os homens e os elementos do mundo, o que implica a procura pela justiça. A poesia seria para ela, então, uma forma de "desalienação" (Ibid.), mobilizada pelos ideais de liberdade e de justiça. Ora, ainda que essas ideias sejam elaboradas pela autora com base em sua concepção sobre poesia, podemos estendê-las para os seus contos, nos quais o elemento "exemplar" mobiliza justamente temas ligados a esse "des-alheamento" do indivíduo diante de sua própria realidade.

Em "O Jantar do Bispo", o leitor é colocado perante um conflito entre o bem e o mal que traduz uma tensão maior: a dualidade entre a pobreza e a riqueza na sociedade de classes. Sua produção inscreve-se no conflito em que um determinado grupo de católicos, dentre eles Sophia Andresen, começa a movimentar-se em oposição ao Estado Novo de Salazar, como observa Eloisa Aragão (2017, p. 40). Essas pessoas, que passaram a ser designadas como "católicos progressistas", "vieram a contribuir nas lutas das campanhas eleitorais da Oposição Democrática" (Ibid.), entre outras ações que buscavam um posicionamento contrário à relação entre o governo de Salazar e a igreja católica.

$\mathrm{O}$ enredo desenvolve-se durante uma noite que abriga um evento importante: o jantar oferecido ao Bispo da região pelo Dono da Casa, um rico e poderoso proprietário de terras. Apesar de parecer uma simples ocasião, o encontro entre as duas personalidades 
guarda um motivo maior: ambos pretendem fazer um pedido, um ao outro, sobre situações que se mostraram problemáticas. Por um lado, temos o dono de terras que deseja a remoção do novo pároco da aldeia. Por outro, temos o pontífice que deseja uma significativa doação para reparar o teto da maior e mais bela igreja de sua diocese.

O cenário desse conto nos remete àquele que já conhecemos por meio do romance Casa na Duna: temos uma região ampla dominada pelo maior proprietário de terras. Seu intenso poder advém de gerações, assim como vimos no caso de Mariano Paulo. O narrador onisciente nos revela que naquelas terras, o pai e o avô do Dono da Casa haviam exercido "uma autoridade indiscutida" (ANDRESEN, 2010, p. 46). Assim, em ambos os textos, esses senhores tinham em suas mãos o domínio da região rural, e sua autoridade era vista pelos camponeses como algo já naturalizado, ou seja, a situação estava em sua ordem normal. Esse controle é concretizado na imagem da casa - a Casa Grande - "cujos donos tinham sido de geração em geração símbolo de honra, virtude, ordem e justiça" (ANDRESEN, 2010, p. 47). Do mesmo modo, observamos na casa de Mariano Paulo a centralização do poder familiar geracional.

A "casa" aparece na obra de Sophia Andresen como um elemento que reúne e interliga o homem ao espaço e às "coisas naturais", sendo um objeto concreto de “convergência, encontro, centro" (SEIXO, 1985, p. 02). É um fator de vinculação do ser ao lugar, do indivíduo ao mundo real, simbolizando e presentificando sua tentativa de “conservar uma eternidade que está latente nas coisas" (Idem, 1986, p. 61). É, logo, um espaço em que se convergem elementos do âmbito concreto e objetivo e da subjetividade do ser. Em Contos Exemplares, a casa também é o lugar onde se reúnem as memórias, não as deixando "à deriva" (Ibid.). Há, assim, na imagem da casa, uma espécie de sincronia entre o ser e o seu mundo, uma harmonia e ligação entre tais elementos.

Essa significação aparece problematizada pelo viés oposto em “O Jantar do Bispo", pois nele a casa concretiza a herança geracional marcada pela autoridade e pelo poder expressos no status social de seus habitantes. $O$ espaço é descrito não pela sincronicidade ou convergência, e sim por desequilíbrio entre sua edificação, sua decoração e seus ambientes exteriores:

Daquela casa tão bela, com as suas linhas limpas, com os seus materiais nobres e pobres, com as paredes caiadas, os azulejos e a grande fachada clara e direita cuja beleza estava só no equilíbrio certo dos espaços e dos volumes e na nudez da cal e da pedra. Mas dentro já qualquer coisa rompia a harmonia. Moveis pomposos, falsos e doirados, tinham sido acrescentados às antigas mobílias escuras. Um estranho novo-riquismo invadia devagar a antiga, simples e austera nobreza. Um excesso de 
tapetes escondia a doce madeira do chão. Cortinas complicadas injuriavam o brilho frio do azulejo e a casta cal das paredes (ANDRESEN, 2010, p. 51).

A casa, em si, guardava seus elementos antigos, o branco da cal, ligado à limpeza, à pureza e à transparência ("casta" cal); o chão conservava o natural e o rústico da madeira. A "nudez", uma noção recorrente na obra andreseniana, pode ser lida como aquilo que está privado de adornos, de enfeites - isto é, de excessos. É também ligada à noção de origem, de primordial - a nudez daquilo que está em seu estado natural, como a pedra. É de tal estado natural que falamos ao imaginar a casa como sincronia entre o ser e o espaço real. Aqui, esse estado contrasta com o artificialismo da decoração da residência.

Esse contraste aponta para a presença da natureza na escrita andreseniana, sendo um "valor eufórico" dos Contos, como observa Clara Rocha (1980, p. 16), pois ora se liga “à ideia de beleza estética e poética, pela sua perfeição e variedade de cores e formas [...], ora representa o lugar de união com aquilo que há de mais verdadeiro, livre e puro no mundo". Sophia traz uma noção de fidelidade a esses elementos naturais, que mobilizam o que há de antigo, de liberto e de original no mundo. Em "O Jantar do Bispo", porém, como demonstra a descrição, esses fatores surgem em oposição à falsa beleza na qual creem os novos ricos habitantes da casa. Em contraste com a beleza primordial e nua da pedra, da madeira, da cal, estão os artefatos falsos, dourados, ostensivos que corrompem a harmonia do espaço real: um duelo entre o natural e o artificial ou, como Rocha afirma, “antinatural” (1980, p. 17).

Outro aspecto que destrói a harmonia encontra-se nos retratos que estão organizados na casa, revelando o máximo do excesso: "E sobretudo - ai!, sobretudo - os retratos do Dono e da Dona da Casa, rosados e estilizados, sentados num cadeirão torcido, ao lado dum jarrão da China, contrastavam amargamente com os retratos secos e sombrios dos antepassados" (ANDRESEN, 2010, p. 51). Os "sombrios retratos" dos antigos familiares retomam uma espécie de valor nobre que essas personagens carregam, pois cada uma delas havia, de certa forma, tentado conquistar algo na perspectiva do proprietário:

Ali estavam quase todos: Aquele que fora ferido em cinco batalhas, aquele que navegara até ao fim do mundo e morrera de escorbuto, o que naufragara no Índico, o que fora denunciado e torturado, o que morrera preso, o que morrera no exílio. [...] Ali estavam quase todos em seus sombrios retratos, ao lado do Dono da Casa que nunca perdera nada (Ibid., p. 52). 
O sombrio e o antigo, que criam por meio dos retratos a ideia de nobreza, de aristocracia dessas personalidades, mas também uma espécie de caráter dado pelas suas atividades, estão em tensão com os excessos do Dono da Casa, que nunca teve de perder, somente possui e ostenta.

Os retratos revelariam uma tradição geracional pela qual todos os antepassados deixam sua marca. No entanto, até tal elemento é falso, pois os quadros mudavam de acordo com os proprietários daquela casa. Ora, temos, então, no Dono da Casa um caráter artificial - no sentido de falso -, excessivo e ostensivo, intensificando a ruptura do equilíbrio entre a sua casa e o mundo real: nada desse proprietário estava em harmonia com o antigo, com a tradição, com o passado. Eram artigos que sustentavam um status de nobreza que ele, aparentemente, não detém. A nudez da cal e a beleza da madeira estão em conflito com a ostentação do dono, que perfaz seu poder por meio daquilo que pode expor. Seu poder se concretiza em tais evidências artificiais.

Nesse contexto, começamos a definir as características do Dono da Casa, o qual seria um novo rico, conforme sugere a narradora, já apontando uma crítica a esse grupo socioeconômico. A sua tradição não é nem de perto nobre - nem no sentido aristocrático, nem no sentido virtuoso. A riqueza da família advém de fontes negativas: o avô enriquecera através do casamento com a filha de um "negreiro", ou seja, um traficante de escravos; seu pai aumentou a fortuna casando-se com a filha de um agiota. "Daí viera um grande acréscimo da riqueza da família, riqueza que agora permitia ao Dono da Casa manter estreitas relações com financeiros dominantes e fazer vários conselhos de administração" (ANDRESEN, 2010, p. 53). Na realidade desse rico proprietário, não interessa, de fato, a origem nobre, e sim o poder financeiro. Porém, seu capital não vem dissociado do status social - ele se coloca como um descendente de uma família tradicional, um modo de garantir seu poder pelo viés geracional, além do financeiro. Há, assim, uma crítica da autora à falsidade e à superficialidade em torno do status social dentro da sociedade, centralizada na ideia do "novo-riquismo". O que importa, na prática, é o poder financeiro. Porém, o fato dessa personagem ter uma linhagem nobre para ostentar é, para ela, um fator de extrema importância.

A posição social do Dono da Casa contrasta com a situação do primo Pedro, um parente afastado que se divertia a olhar os retratos dos antigos aristocratas. Ele "era o mais legítimo representante da nobreza da província e o mais arruinado" (Ibid., p. 52). Sua família, a partir de seu avô, entrou em falência, algo que o narrador observa como "um pouco inexplicável”: "Eles não desperdiçam só os seus bens mas também seus dons. 
As suas qualidades não encontram forma de realização. É como se a relação entre eles e a vida estivesse quebrada" (Ibid., p. 53). Uma das possíveis explicações da ruína da família pode ser vista no fato de o avô de Pedro ter se casado "com um actriz da época romântica", escandalizando a aldeia, e seu pai casou-se com alguém sem posses também. Apesar disso, o Dono da Casa fazia questão da presença do primo Pedro, pois significava a genealogia da família.

Em tal relação com o primo falido, podemos notar mais um aspecto associado à noção de status social posto em relevo no conto "O Jantar do Bispo". Assim como observamos a necessidade de se manter as aparências mostradas por algumas personagens em Pequenos Burgueses, de Carlos de Oliveira, voltamos a ver tal fator na situação mantida pelo Dono da Casa. Esse parente representa, de certo modo, uma família que teve, em seu passado, bens e posses. Há uma ideia de aristocracia por trás desse descendente despossuído que o proprietário quer ostentar. Ele representaria a tradição geracional que tanto o Dono da Casa queria impor ao se orgulhar de tantos retratos de antepassados na parede, sendo que, na verdade, não eram seus familiares. Desse modo, a autora relaciona à camada dos novos ricos - que não advém necessariamente de uma linhagem aristocrata - a superficialidade e artificialidade do mundo de aparências - o véu que cobre a realidade, como observou o narrador de Pequenos Burgueses.

Embora a presença de Pedro agradasse o Dono da Casa, ele não fora convidado para o jantar do Bispo. O familiar arruinado falava de ideias que desagradavam o proprietário rural: “[...] tinha opiniões subversivas: defendia a democracia, a liberdade de imprensa, o direito à greve e costumava citar o catecismo dizendo que não pagar o justo salário a quem trabalha é um pecado que brada aos céus" (ANDRESEN, 2010, p. 54). Por isso, o rico proprietário supunha que o primo era comunista e sua presença seria completamente incoerente com o motivo do evento, afinal o que se queria com esse jantar era a demoção do Padre de Varzim para outra aldeia. Aquela reunião pedia, então, prudência: ele só poderia convidar quem realmente oferecesse-lhe apoio à causa e certamente o primo arruinado, mas comunista, defenderia o pároco.

O que era tão perigoso em tal abade? Ele era visto como uma "semente de guerra" (Ibid., p. 46), pois seus discursos vinham de encontro à autoridade indiscutida da família do proprietário. Em seus sermões, o "novo padre falava duma justiça que não era a justiça do Dono da Casa" (Ibid.). A ordem reconhecida por este refere-se ao poder que mantinha na miserável aldeia de Varzim, cuja pobreza era aceita há muito tempo com resignação pelos camponeses, os quais trabalhavam nas vinhas da casa grande. "Havia muito tempo 
que Varzim era pobre e sempre cada vez mais pobre, e havia muito tempo que os párocos de Varzim aceitavam com paciência, sempre com mais paciência, a pobreza de seus paroquianos" (Ibid.). Mas não o novo abade. Sua pregação agora colocava a figura do Dono da Casa como um acusado, "como um dedo que apontava" (Ibid.) a injustiça e a miséria na qual os fiéis estavam inseridos:

O discurso do Padre parecia que "chamava a julgamento [o Dono da Casa] para responder pelos tuberculosos cuspindo sangue, pelos velhos sem sustento, pelas crianças raquíticas, pelos loucos, os cegos e os coxos pedindo esmolas na estrada. (Ibid., p. 47)

Houve, por exemplo, um episódio que intensificou o conflito entre o rico proprietário e o novo pároco: um caseiro quis discutir as contas com o patrão e logo o abade defendeu o trabalhador. Irado, o Dono da Casa questionou o religioso:

Eu pensava que o seu ofício era ocupar-se de rezas e não de contas. Os problemas morais pertencem-lhe. Os problemas práticos são comigo. [...] Eu na sua Igreja não mando, só assisto e apoio. O problema que estamos a discutir é meu, é do mundo, é um problema material e prático. (ANDRESEN, 2010, p. 47)

O padre, porém, retrucou: "Da nossa própria fome podemos dizer que é um problema material e prático. A fome dos outros é um problema moral (Ibid.).

Ora, essa personagem veio desequilibrar a ordem que há tantos anos o Dono da Casa e sua família impunham na pobre Varzim, onde os camponeses esperavam com fome e paciência - noção que remete à paciência observada por Carlos de Oliveira sobre a organização na quinta de Mariano Paulo. A miséria não era problema do proprietário, não era concernente à sua classe, nem à sua posição social. Ele "estava velho e habituado a mandar e a possuir. As suas conveniências, as suas comodidades, as suas vantagens e os seus interesses pareciam-lhe direitos éticos absolutos, princípios sagrados da paz e da ordem" (Ibid.).

Nesse aspecto, a ordem e a ética dessa personagem residem na ideia de poder. Sua conduta pode ser vista como antiética, considerando a perspectiva da narradora. "Ordem" não significa uma estrutura lógica e justa para ele, tampouco a ética. Há uma inversão no pensamento do proprietário. Seus privilégios são direitos conquistados pelo poder de capital e de influência que sua família obteve. As necessidades dos camponeses não lhe cabem. Afinal, são trabalhadores e recebem por isso. O direito dos aldeões à vida digna da qual nos falava Dr. Seabra não existe ou, pelo menos, não lhe são concernentes. A inversão ocorre também na ideia de "correto" - que seria o comportamento paciente dos 
antigos párocos. O novo homem de Deus era um desvio, era um obstáculo à normalidade que precisava ser calado. Por isso, então, o evento da noite narrada era tão importante.

Podemos fazer, nesse ponto, algumas reflexões comparativas entre o conto e Casa na Duna, justamente pelo fato de ambos os textos estarem inseridos em cenários semelhantes: a organização do mundo rural. Temos duas personagens que estão habituadas à sua condição mandante de controle: os dois grandes proprietários e são colocadas frente a frente com a pobreza de seu território. Um fator, porém, diferencia-os: Mariano Paulo, talvez por estar diante de um colapso na sua própria situação social, apresenta uma certa consciência e alguma culpa em relação à miséria que assola seus camponeses. O Dono da Casa, por sua vez, distancia-se desse assunto, considerando que já faz muito pelos pobres.

Como um fiel de Deus, ele praticava a caridade - à sua maneira. Mantinha em sua casa a mesa dos pobres na cozinha. "A qualquer hora do dia naquela mesa era servida uma refeição a qualquer mendigo que batesse à porta" (ANDRESEN, 2010, p. 50). Porém, não eram todos os miseráveis que poderiam valer-se de tal benefício: “[...] era preciso que o mendigo fosse doutras terras ou que, sendo do sítio, fosse reconhecido como um verdadeiro pobre" (Ibid.), ou seja, indivíduos com algum tipo de deficiência que lhes impedia de trabalhar, como Lúcio, um homem que não tinha pernas.

Na lógica do Dono da Casa, a pessoa que poderia ser força de trabalho já não era considerada um verdadeiro pobre e, naturalmente, não deveria receber nenhuma benesse da sua caridade, afinal ele já fazia sua parte ao pagar os salários. O valor do indivíduo é, em tal perspectiva, validado pela sua capacidade de oferecer força de trabalho. Assim como vimos no caso de Lobisomem, que era valorizado enquanto era um touro, uma "besta de carga", o proprietário de Varzim mantinha o mesmo pensamento. O Pedro da Serra, por exemplo, não era pobre: ele tinha dois braços e podia trabalhar. Apesar disso, ganhava uma jorna miserável e tinha nove filhos para sustentar. Isso não era, no entanto, digno de caridade.

Tal concepção fazia parte de uma estrutura natural e aceita - assim como a de Corrocovo. Os privilégios da classe favorecida não são vistos como prerrogativas, e sim como um direito adquirido e justo. Em contrapartida, os direitos não cumpridos da classe desfavorecida são vistos "problemas morais", ou seja, são questões de fé. O pobre do Pedro da Serra possivelmente rezava para obter melhores condições de vida. Ele não ia pleiteá-las com o seu empregador. Ora, de acordo com esse pensamento, Deus seria responsável por oferecer a justiça àqueles que creem, e não quem os emprega e paga-lhes 
baixos salários. Para esse proprietário - que se insere na camada da elite rural - a questão da pobreza não é resultado nas péssimas condições de remuneração oferecida por ele, mas antes uma questão moral, lida aqui como um aspecto subjetivo, o que deveria ser abordado na Igreja. Convenientemente, a miséria era tida como um dado existente na vida dos camponeses, e não como consequência da sua conduta enquanto patrão.

Nos seus sermões, o padre falava de caridade e de justiça conforme observa a narradora. Não era essa, porém, aquela praticada pelo Dono da Casa enquanto estava envolvido em seu "papel" de bom cristão. O pároco alertava para o conceito base da sociedade de classes: a exploração. E esclarecer os aldeões sobre isso era uma forma de subverter a ordem social correta e digna aos olhos do patrão, o que ele desejava explicar ao Bispo quando pedisse para remover o novo abade:

Queria explicar claramente que o padre novo era um perigo para a ordem social, aquela ordem que ele, dono dos campos, dos pomares, dos pinhais e das vinhas, no centro do jardim bem podado, bem plantado e bem varrido, no centro da casa antiga bem tratada, bem caiada e bem encerada, no centro das pratas herdadas e das pratas compradas, no centro dos moveis velhos e dos tapetes novos, representava (ANDRESEN, 2010, p. 55).

A ordem adequada era aquela do poder econômico, e a justiça da qual o homem religioso falava era uma ameaça a esse domínio. O que vale para aquele cenário é, desse modo, a ética invertida do proprietário, ameaçada pelos sermões do novo pároco.

Convém observar que a personagem do padre de Varzim é inspirada na vida de Abel Varzim (1902-1964), cuja vida foi dedicada às causas sociais, como observa Aragão (2017, p. 47). Além de sua formação em Teologia, Varzim concluiu seu doutorado em Ciências Políticas e Sociais na Bélgica, "tendo como objeto de estudo a liga dos agricultores católicos e o contexto da pobreza a que estavam submetidos" (Ibid., p. 48). O padre dedicou-se ao apoio dos movimentos operários e foi Deputado na Assembleia Nacional de 1938 a 1942. "A postura crítica de Varzim acerca das condições laborais e sua reivindicação por medidas de proteção aos trabalhadores atraíram ameaças do regime ditatorial", como explica Aragão (2017, p. 48).

Trabalhou ainda com uma atividade de reintegração social de prostitutas e fundou projetos que ofereciam cuidados médicos e alimentação aos mais pobres. Porém, neste momento passa a ser vigiado pela PIDE, tornando-se um “desafeto de Salazar": "Se de início Abel Varzim, assim como um grande número de católicos, apostou no programa social e político fundado no corporativismo do Estado Novo, aos poucos foi se dando 
conta de seus muitos entraves e limitações [...]”. (ARAGÃO, 2017, p. 48). Mantém-se como opositor do regime ao longo de sua vida, quando volta ao Porto, onde falece em 1964.

O pároco de Varzim tem, como podemos observar, inspiração na vida de Abel Varzim, posicionando-se contra a visão disseminada pelo Dono da Casa e discutindo entre os pobres fiéis noções perigosas ao controle político-econômico daquela população. Ele atua no conto como Dr. Seabra em Casa na Duna, expondo ao leitor, por um lado, o discurso da igualdade e justiça e, por outro, explicitando a inversão da ordem relativa à personagem do proprietário rural. No entanto, há algumas diferenças marcantes nessa figura em relação ao médico do romance neorrealista. Ambos lidam, de alguma forma, com os resultados da pobreza e da exploração dos aldeões. Dr. Seabra cuida da saúde precária dessas pessoas, enquanto o pároco cuida deles em âmbito espiritual e emocional. Aquele observa os problemas enfrentados e comunica à classe abastada, na figura de Mariano Paulo, mas ele não assume um caráter mobilizador da camada subalterna. $\mathrm{O}$ pároco, por sua vez, alerta os camponeses através de sua pregação para os assuntos ligados a essa injustiça social, agindo, de certa forma, como um representante das mazelas vivenciadas pelo grupo e promovendo uma possível mobilização deste.

Dessa maneira, a polaridade entre as classes torna-se evidente e crítica no conto, ainda que não haja especificamente uma personagem da classe dos aldeões a falar sobre sua situação. É justamente por esclarecer a desigualdade estabelecida como ordem natural que o abade se torna uma grave ameaça ao Dono da Casa, afinal os sermões dele poderiam, por exemplo, movimentar os camponeses em direção à reivindicação de seus direitos. Em âmbito pessoal, o padre também questionou tal estrutura. O proprietário achava que ele vinha de alguma família humilde. Porém, descobriu que era, na verdade, um "parente afastado duns seus parentes afastados e que a fome escrita na sua cara não era hereditária, mas sim voluntária" (Ibid., p. 48).

Esse fato preocupava ainda mais o Dono da Casa, pois o padre "rejeitara o seu lugar entre os ricos e tomara seu lugar entre os pobres" (Ibid.), mostrando não respeitar aquilo que o proprietário dizia - "Todo poder vem de Deus" (Ibid.). O abade mostrava não respeitar essa prerrogativa atribuída àqueles que têm dinheiro. A posição social era, para o rico senhor, algo a ser respeitado:

E pensava que um padre devia por isso respeitar todo o poder estabelecido e respeitar o dinheiro e a importância social, expressões do poder. E considerava também inadmissível que um homem rejeitasse a herança dos seus para alinhar ao lado de miseráveis. Um homem de 
boas famílias se vai para padre deve ser Bispo, Núncio ou até Papa. Mas pelo menos Monsenhor. Nunca pároco de uma aldeia numa serra. A atitude do padre novo chocava-o como uma traição (ANDRESEN, 2010, p. 48-49).

Por isso, seu deslocamento era essencial, pois ele representava algo muito além da mobilização dos camponeses: renegava o poder da classe dominante, indicando que os direitos gozados por ela eram, na realidade, privilégios obtidos pela exploração. Ao refutar a sua herança, ele recusa aproveitar-se de uma posição que se impõe através do domínio e da injustiça. Além disso, refuta também a hierarquia, algo importante para o Dono da Casa.

Nesse contexto, podemos comparar a percepção de realidade tida pelo pároco à do Dr. Seabra, ressaltando que ambos lidam diretamente com o sofrimento dos aldeões. O discurso dessas personagens suscita ao leitor uma reflexão sobre a desigualdade social e a exploração do trabalhador, pois oferecem elementos que explicitam a condição de vivência dos grupos mais pobres. Porém, não temos no conto uma personagem específica dessa camada. Apenas conhecemos o caseiro que reclama ao Dono da Casa suas contas, defendido pelo padre. Não podemos, assim, falar também em luta de classes nesse texto, mas, sim, em polarização entre o setor rico e o pobre.

Tal oposição torna-se ainda mais intensificada pelo fato de a narradora detalhar como funciona a lógica de caridade do Dono da Casa, que destina comida e esmola apenas a deficientes mentais ou físicos. Essa posição contrasta com o discurso de caridade do padre, que se une aos ideais de justiça. $\mathrm{O}$ antagonismo entre ambos se configura como uma das principais oposições presentes no conto, o qual começa a se delinear a partir desse conflito e abre-se para uma reflexão mais ampla entre o bem e o mal pautada no diálogo que Sophia Andresen traz com aspectos cristãos.

Valendo-se de elementos simbólicos e alegorias, o conflito entre miséria e riqueza estende-se em Contos Exemplares valores morais que se colocam entre pobreza e nobreza de princípios. Esse debate torna-se mais crítico ao considerarmos que a temática se desenvolve dentro de um contexto em que pessoas se dizem religiosas, especificamente cristãs. Como já observamos, o Dono da Casa é definido pelo seu caráter religioso questionável, pois apenas cumpre de forma superficial com aquilo que sua religião prega. Vai às missas aos domingos, serve comida a alguns pobres e dá esmolas aos sábados. Vêse como um homem bem-educado e crê em seus valores éticos, pois julga ter boa criação e ser fiel, como seria o esperado - na sua visão - de um descendente de família aristocrática, imagem desmontada pela narradora quando fala da sua linhagem. 
Acima de tudo, o Dono da Casa é um rico proprietário rural cujo princípio central é regido pelo poder que mantém na pobre aldeia de Varzim. Por isso, o jantar que oferece ao Bispo é, na realidade, uma reunião de negócios. Do mesmo modo que um patrão repensa a função de um empregado que não acata suas ordens, essa personagem rejeita a função do pároco e precisa do Bispo para fazer uma intervenção adequada. Ocorre, porém, que o Bispo também tem um negócio a tratar com o rico proprietário. Do mesmo modo, ele precisa do apoio para restaurar o teto de sua igreja. O evento, assim, não tem nada de religioso, é uma conversa entre duas partes motivadas pelos seus interesses.

É interessante observarmos, porém, que tanto o Dono da Casa como o Bispo estavam desconfortáveis com a situação. O proprietário admitia que o novo padre vivia modestamente, via nele um fraco adversário vestido de roupas esfarrapadas e botas gastas, como se fosse mais um aldeão pobre. Enquanto o Bispo não chegava à sua casa, o rico homem repensava em todos os seus argumentos, mas sabia que seria um pedido difícil de se fazer. Paralelamente, o Bispo ia em seu carro com um chofer para o jantar e repensava na necessidade de dinheiro para o reparo da bela igreja. Ele também revia seus argumentos, mas achava incômoda a posição em que estava: "Pedir é uma coisa difícil. E tanto mais difícil quanto mais aquele a quem se pede é rico e poderoso. Mas a quem havia ele de pedir senão aos ricos e poderosos?" (ANDRESEN, 2010, p. 55).

Neste ínterim, o Bispo tem uma reflexão extremamente importante para pensarmos sobre os valores éticos problematizados pelo conto. A bela igreja cujo teto estava a desmoronar havia sido construída por um antepassado do Dono da Casa no século XVII, "pois nos tempos antigos, quando um homem poderoso se achava doente ou tinha a consciência pesada, fazia a promessa de mandar construir uma igreja para dar paz ao corpo e à alma" (Ibid., p. 56). Nos dias de hoje, entretanto, "há remédios para todas as doenças e argumentos para todas as consciências" (Ibid.). Os homens poderosos, assim, já não lidam com suas doenças e com o medo da morte da mesma maneira, já não constroem igrejas para alcançar o perdão de Deus e a sua redenção, e isso tornava toda a situação mais difícil ainda.

O Bispo, nesse momento, reflete que nos dias de hoje (da narrativa) as doenças não são a mesma coisa para ricos e pobres. "Agora com regime, análises, radiografias, clínicas curas de sono e vitaminas, um homem rico tem a saúde quase assegurada” (Ibid.). O homem poderoso de antigamente temia a morte e era temente a Deus, "e agora as certezas burguesas varreram a inquietação e tornaram inútil a esperança” (ANDRESEN, 2010, p. 56), ou seja, a religião não é mais o conforto diante do medo de doenças, pois o 
dinheiro pode assegurar as certezas dos ricos e poderosos. Ainda assim, o religioso pretendia fazer o pedido, mas julgava o Dono da Casa um homem virtuoso conforme tal reflexão: "Os homens virtuosos são sensatos e prudentes, e a generosidade, sendo a virtude daqueles que dão aquilo que lhes falta, é em si mesma uma coisa insensata, contrária aos hábitos dos homens prudentes" (Ibid.).

Novamente, temos uma dualidade na concepção de "generosidade" segundo o Bispo. Para os ricos, ser generoso é uma questão de prudência, e não de dar "aquilo que lhes falta". Esse raciocínio coaduna-se à mentalidade do Dono da Casa diante da caridade praticada. São conceitos de conveniência e superficialidade. Por isso, o Bispo desconfiava de que seu pedido não desse resultado, pois, sendo um homem virtuoso, logo sensato, o proprietário não seria, de fato, generoso. Nem sua religiosidade era realmente genuína, como a narradora nos relata. Ele cumpre uma agenda de ser um bom cristão, quando não o é na realidade, e o Bispo sabe disso. Ser generoso é, de certa forma, uma virtude daquele que se dispõe a sacrificar algo pelo outro, pelo benefício de um outro indivíduo, o que justamente era algo incoerente à sensatez dos homens poderosos.

O pensamento cristão vê na generosidade a prática de um dos seus principais mandamentos: amar uns aos outros assim como Deus nos amou. Conforme essa visão, um indivíduo cristão deve conseguir colocar-se diante do outro da mesma forma que Deus. O Bispo sabe, contudo, que um homem poderoso não pratica tal conceito, uma vez que o poder se dá não pela capacidade de altruísmo nem alteridade, e sim pela subjugação. Por isso, reflete: “Generosos são só os loucos ou os santos" (Ibid.), assim como o novo pároco, que abdicou do seu lugar de riqueza para viver entre os miseráveis, sendo um deles.

Havia um detalhe, porém, que dava certa esperança ao Bispo: o Dono da Casa era um "homem oficialmente virtuoso" (Ibid., p. 57), isto é, mantinha a aparência de ser generoso, sendo, portanto, vaidoso, "pois a sua longa experiência lhe ensinara que os homens virtuosos são geralmente vaidosos ao extremo. Cultivam com cuidado a sua boa fama, que querem esplêndida e conhecida" (Ibid.). A caridade do poderoso homem é, assim, uma aparência, um valor superficial que se faz questão de cultivar. O Bispo, em sua reflexão, compara-o aos fariseus ${ }^{94}$, antigo agrupamento religioso hebraico da época pós-exílica ${ }^{95}$ que prezava a pureza e os dogmas da Torá, livro sagrado do Judaísmo. No século 1. a.C., esse grupo mantinha-se como líder dos judeus e não reconheciam Jesus

\footnotetext{
${ }^{94}$ Apresentamos uma leitura mais detalhada desse tema in: NAHAS, N., 2015, pp. 90-94

95 Período que compreende, aproximadamente, os anos de 333 a.C. a 70 d.C.
} 
como um messias, opondo-se fortemente ao Cristianismo conforme observa Schubert (1979, p. 32). Na Bíblia, há uma famosa passagem que indica a desconfiança desse grupo em relação a Jesus:

1. Jesus tomou de novo a barca, passou o lago e veio para a sua cidade. 2. Eis que the apresentaram um paralítico estendido numa padiola. Jesus, vendo a fé daquela gente, disse ao paralítico: "Meu filho, coragem! Teus pecados te são perdoados." 3. Ouvindo isto, alguns escribas murmuraram entre si: "Este homem blasfema." 4. Jesus, penetrando-lhes os pensamentos, perguntou-lhes: "Por que pensais mal em vossos corações? 5. Que é mais fácil dizer: Teus pecados te são perdoados, ou: Levanta-te e anda? 6. Ora, para que saibais que o Filho do Homem tem na terra o poder de perdoar os pecados: Levanta-te disse ele ao paralítico -, toma a tua maca e volta para tua casa. ${ }^{96}$

Os fariseus, assim, acreditavam que Jesus blasfemava ao falar com pecadores, como doentes, prostitutas e arrecadadores de impostos, revelando uma certa postura hierárquica no discurso religioso.

No Evangelho de São Mateus, consta que teria sido esse grupo que tramou a morte do suposto filho de Deus:

9. Partindo dali, Jesus entrou na sinagoga. 10. Encontrava-se lá um homem que tinha a mão seca. Alguém perguntou a Jesus: É permitido curar no dia de sábado? Isto para poder acusá-lo. 11. Jesus respondeulhe: Há alguém entre vós que, tendo uma única ovelha e se esta cair num poço no dia de sábado, não a irá procurar e retirar? 12. Não vale o homem muito mais que uma ovelha? É permitido, pois, fazer o bem no dia de sábado. 13. Disse, então, àquele homem: Estende a mão. Ele a estendeu e ela tornou-se sã como a outra. 14. Os fariseus saíram dali e deliberaram sobre os meios de o matar. ${ }^{97}$

Assim, segundo a Bíblia, não aceitavam as ações de compaixão e misericórdia de Jesus e julgavam que ele transgredia as leis de Moisés, tão preservada por eles. O messias e seus apóstolos evitavam os fariseus, referindo-se a eles como uma "geração adúltera e perversa”, conforme explica Schubert (1979, p. 32-33).

Para os cristãos, os fariseus são considerados responsáveis, de certa forma, pela morte de Jesus e são vistos como pecadores que agem em prol das aparências da religião e do poder que detinham sobre os fiéis. Sophia Andresen, em seu diálogo com o discurso cristão, traz esse antigo agrupamento como símbolo do comportamento daqueles que agem superficial e falsamente para manter seu poder. No mesmo ano que publica os

\footnotetext{
${ }^{96}$ Evangelho de São Mateus, capítulo 9. In: Bíblia Sagrada. Versão Eletrônica.

97 Ibidem, capítulo 12, versículo 9.
} 
Contos Exemplares, a autora publica, em seu Livro Sexto, o poema "A Veste dos Fariseus" "98, no qual tematiza, além da questão da falsa aparência, a questão da injustiça praticada contra Cristo:

Era um Cristo sem poder

Sem espada e sem riqueza

Seus amigos o negavam

Antes do galo cantar

A polícia o perseguia

Guiada por Fariseus

O poder lavou as mãos

Daquele sangue inocente

Crucificai-o depressa

Lhe pedia toda a gente

Guiada por Fariseus

Foi cuspido e foi julgado

No centro duma cidade

Insultos o perseguiram

E morreu desfigurado

O templo rasgou seus véus

E Pilatos seus vestidos

Rasgaram seu coração

Maria Mãe de João

João Filho de Maria

A treva caiu dos céus

Sobre a terra em pleno dia

Nem uma nódoa se via

Na veste dos Fariseus ${ }^{99}$

No poema, vemos a figura dos fariseus por trás de toda a ação que levou Jesus à sua condenação. O filho de Deus aparece com uma figura alijada de poder e sem riquezas, renegado pelos amigos e perseguido, por ordens do agrupamento judaico. Seu sangue inocente, segundo a voz poética, fora maculado pelo poder daqueles que o mataram. A população pedia sua crucificação, pois estava mobilizada pelos fariseus. Assim, nos versos em redondilha maior, acompanhamos a descrição da Paixão de Cristo, atualizada nos tempos atuais, marcados pela ânsia de poder e pela opressão - como observamos no uso do termo "polícia", algo representativo do contexto de cerceamento político no qual Sophia publica ambas as obras.

A "veste dos Fariseus" mostra, por um lado, o poder e suas aparências. A condenação de um homem misericordioso e inocente não sujou as mãos - nem as roupas

\footnotetext{
98 Apresentamos uma leitura mais detalhada desse poema in: NAHAS, N., 2015, pp. 90-94.

99 ANDRESEN, 2011, p. 434.
} 
- daqueles que o levaram à morte, pois eram líderes poderosos econômica e religiosamente. Por outro, observamos também o poder de influência. As nódoas, que suscitam a ideia de sujeira, não aparecem, uma vez que Fariseus agiram de forma manipuladora sobre a população que preferiu salvar Barrabás ao suposto messias. Há aqui uma alusão ao poder não somente pela questão física, mas também pelo aspecto intelectual. Os fariseus são lidos como os mentores da morte de Jesus e, pelo seu prestígio e posição social, mantêm-se ilibados da culpa, limpos.

Se lermos o poema em associação ao pensamento do Bispo, podemos encontrar na figura do Dono da Casa essas características suscitadas pela voz poética. O proprietário representa o poder físico mas também intelectual da ideologia dominante, ambos oriundos da posse de capital. Sua bondade resume-se à superfície de homem bem-educado, nobre, aristocrático, estando interessando em manter sua influência, e não em ajudar quem necessita. Se estendermos essa leitura à continuidade do conto, podemos verificar que o poder ideológico dele também vai ser exposto quando tenta negociar a demoção do padre de Varzim. Se o deslocamento fosse, de fato, realizado, as "mãos" que levariam a essa mudança seriam as do Bispo, e não do Dono da Casa, que se manteria inocentado, oculto pelas aparências de bom cristão e por sua posição social.

Mas o Bispo estava mobilizado por uma razão maior: o conserto de sua igreja. Por isso, tinha de jogar o jogo das influências, mesmo consciente de todos esses fatores. Ele reflete: "É triste estar a confiar na vaidade dos homens" (ANDRESEN, 2010, p. 57). Mais triste e desconfortável ainda foi o momento em que o homem religioso percebeu que não estava na casa para fazer um pedido. Era, na realidade, parte de uma negociação. Porém, o leitor já havia sido advertido, parágrafos antes, de que "o Diabo que espreita a ocasião", (Ibid.) intervindo em tal trâmite. Assim que o Bispo adentrou a casa, um forte estrondo foi ouvido. Como o dia era de intenso temporal, logo cogitou-se a ideia de algum acidente de carro. De fato, um automóvel "preto e sumptuoso" (Ibid., p. 59) havia colidido com o extenso portão da propriedade. O homem que o dirigia se conduz para dentro e se apresenta: "O desconhecido disse o seu nome. Um nome que foi ouvido com prazer. Era o nome dum homem importantíssimo" (Ibid.).

O misterioso indivíduo que surge torna-se um convidado do jantar e logo conquista a todos. Porém, o pequeno João, filho do Dono da Casa, não gosta dele e olhao de modo desconfiado. Ele tinha 9 anos e espanta-se com a "sombra tão grande" (ANDRESEN, 2010, p. 59) do homem. Isso não impede que a sua presença seja comentada por todos e ele começa a expor sua opinião durante o evento, trazendo ideias 
que vêm ao encontro dos planos do rico proprietário de pedir a demoção do pároco de Varzim. Tal personagem que surge inesperadamente começa a delinear-se como alguém de opinião contundente, apresentando uma forte influência aos "negócios" que seriam discutidos entre o Bispo e o rico homem.

Na sua fala, o Homem Importante afirma que os tempos atuais são marcados pelo "materialismo", o que é uma crise segundo a personagem. A partir disso, desenvolve sua ideia:

Até nos campos onde só devia reinar a espiritualidade, ouvimos constantemente falar de problemas materiais. Shakespeare, Camões, Dante falaram dos problemas da alma humana. Hoje os poetas discutem os salários dos operários e o nível de vida dos países. Ora, o homem não é só matéria, é espírito também. Mas o nosso tempo só vê os problemas materiais. É tempo de revolta. (Ibid., p. 60)

Nessa reflexão, observamos o posicionamento contrário às influências de um pensamento social, influenciado pelas ideias marxistas. Os escritores, segundo a personagem, deixaram de ocupar-se da "alma humana" para discutir a questão socioeconômica dos trabalhadores e dos países, o que chama de materialismo. Ele ainda prossegue:

Os homens não querem aceitar. Paciência e resignação são palavras que perderam o sentido. O homem deste tempo quer que o reino de Deus seja deste mundo. É o pecado da revolta. [...] Mas o mais grave de tudo, aquilo que verdadeiramente é motivo de escândalo, é vermos que o espírito do materialismo e de revolta se infiltra não só entre os católicos, mas até entre os próprios padres. (Ibid., pp. 60-61)

Seu discurso era, basicamente, tudo o que o Dono da Casa precisava ouvir para conseguir fazer o seu pedido, afinal ele sabia da dificuldade da situação.

O Bispo, no entanto, observou que a Igreja não pode se desinteressar pelas questões sociais. O Homem Importante continuava seu discurso, expondo que a missão da instituição é transcendente, não lhe compete lidar com problemas materiais. Diz ainda que o princípio da caridade é mal interpretado por muitos, inclusive chegam a existir padres que parecem comunistas. Obviamente o Dono da Casa concordou com êxito, pois tinha em mente justamente o padre de Varzim. O homem misterioso ainda ressaltou que é uma "triste esperança" esperar por soluções materiais. (ANDRESEN, 2010, p. 62). O golpe de influência de tal personagem ocorre, porém, quando cita que viu o teto de uma bela igreja em ruínas. Nesse momento, o leitor encontra-se diante da ideia referida páginas antes sobre o diabo estar observando a ocasião. 
O Dono da Casa, o Bispo e o Homem Importante reúnem-se sozinhos para enfim discutirem os negócios. O rico proprietário já não sentia hesitação após o discurso da figura misteriosa e estava muito contente com o rumo do jantar, afinal "Nada lhe agrava mais do que dar de comer a quem não tem fome" (Ibid., p. 63). Seu status social se consolidava nas ocasiões de festas e jantares, "sentia-se reinar sobre as loiças e sobre os convidados" (Ibid.), e ainda pensou: "Sólido era o peso dos talheres de prata. Sólido era o seu reino. O Abade de Varzim era uma pobre sombra, um fantasma perdido entre pedintes e fragas, irreal e abstracto como uma ideia que não é deste mundo" (Ibid.). De fato, o comportamento do padre não fazia parte da ordem social tida como correta e natural segundo a qual funcionava a mente do Dono da Casa. Os discursos comunistas eram o mau daquele tempo. Os homens não esperavam com resiliência e paciência, e ele não poderia querer alguém que influenciasse a alma - e a mente - de seus trabalhadores com pensamentos tão materialistas. O Homem Importante, nesse cenário, passa a advogar em defesa do rico senhor, de modo a mobilizar o Bispo a aceitar a doação em troca do deslocamento do pároco. Ele se delineia como um "advogado do diabo", e o destino daquele que fala pelo povo está em debate.

Observamos no conto um pensamento que já vimos em Casa na Duna e Pequenos Burgueses, as ideias marxistas que refletem sobre a exploração social e a desigualdade surgem como uma forte desordem da estrutura social estabelecida há muito tempo, na qual uma classe domina e outra é explorada. Mariano Paulo alertava Dr. Seabra que alguns lhe chamavam de comunista; no outro romance há a personagem de João Viegas, cujo discurso de "marxismo urgente" (OLIVEIRA, 2005, p. 55) levo-a ser preso por um suspeito carro preto, talvez em uma referência à polícia política portuguesa (PIDE). O conto, que não tem um contexto bem definido, traz também a noção de ameaça do discurso de base materialista histórica, uma vez que ele promove uma inversão na organização de poder e de posse.

É interessante, porém, verificar que, para Marx, a religião era uma forma intensa de alienação do homem em relação aos próprios homens, uma vez que o indivíduo aliena uma parte de si mesmo e suas atividades na forma de Deus, tornando-lhe impossível constituir-se como ser humano completo. ${ }^{100}$ Além disso, o pensador "considerava o cristianismo, com a sua fixação no homem e na alma individuais, e particularmente sua versão burguesa protestante, o credo mais apropriado a uma economia da troca anônima

100 Verbete “alienação”. In: Dicionário do Pensamento Marxista (Versão Digital). 
de mercadorias". ${ }^{101}$ Friedrich Engels, por sua vez, analisou o protestantismo como uma crença "ajustada às mais ousadas aspirações burguesas ou dos primeiros grupos capitalistas de seu tempo". ${ }^{102}$ Em seu texto As Lutas de Classe na França, de 1848 a 1850, Marx reconhecia que, em um país de base essencialmente camponesa, a influência clerical poderia ser aceitável, contudo observou, em uma viagem pela região oeste alemã, que havia uma espécie de catolicismo social que exercia um "efeito insidioso" para os trabalhadores. ${ }^{103}$

No conto, porém, ocorre uma aproximação entre o padre - e seu suposto papel comunista - e um ideal pautado no marxismo ligado à crítica sobre a exploração. Pelo recurso do discurso indireto livre, que aparece em alguns trechos do narrativa, observamos que o Dono da Casa classifica como "desordem, anormalidade, bolchevismo" as ações do pároco. Ele reflete que, antes, podia ficar distraído na missa a olhar as pinturas do teto, afinal os sermões falavam de paciência e esperança de uma vida melhor, algo que não lhe dizia respeito. O mundo em que ele vivia já era para si o melhor dos mundos. Não esperava a transcendência, pelo contrário. Queria gozar da ordem imposta pelo seu poder por mais tempo possível. Mas agora as ocasiões da missa o alertavam, pois o padre falava de caridade " $\mathrm{E}$ a caridade de que ele falava não era a conhecida e pacífica praxe das comedidas esmolas regulamentares. Era um mandamento de Deus solene e rigoroso, uma palavra nua de Deus atravessando o espírito do homem" (ANDRESEN, 2010, p. 49-50). A nudez retoma a ideia de palavra "pura", "verdadeira", mas também se refere à noção de concretude desse discurso, que rasga o véu da aparente religiosidade do rico homem.

O modo como Sophia elabora sua narrativa aproxima a todo o momento o discurso cristão da visão social por meio das ações e do comportamento do Padre de Varzim. Há, no entanto, outro aspecto que nos permite analisar o modo como a relação entre classes é inserida no conto a partir da Parte II, quando chega à grande casa um mendigo. Eram dez horas da noite e, com duas batidas à porta, o homem fez anunciar sua presença. A cozinheira Gertrudes, que o recebera, nem se importou em questionar-lhe quem era, afinal “era mais um pobre" (ANDRESEN, 2010, p. 67). De fato, ela estava estafada com o jantar e a hora já era avançada, mas o que realmente a preocupava era a sujeira de barro trazida pelos pés do pobre homem: “Os trapos encharcados do mendigo escorriam água. Poisados

\footnotetext{
101 Verbete “Cristianismo”. In: Dicionário do Pensamento Marxista (Versão Digital).

102 Ibidem.

103 Ibidem.
} 
no chão de tijoleira, os seus pés descalços estavam molhados e cobertos de lama" (Ibid.). Ao chegar, o homem saudou a cozinheira e a velha empregada, Joana, porém só obteve resposta desta. Gertrudes estava somente preocupada com a sujidade dele.

A senhora Joana, que estava ao lado do fogo, diz ao mendigo que se aproximasse para secar os pés, mas Gertrudes fora enfática apontando-lhe seu lugar na mesa. Aquele era o seu local de permanência: a mesa dos pobres. A cozinheira ainda lançou um olhar desconfiado aos talheres de prata que poderiam estar em risco com a presença de um mendigo, mas logo percebeu a distância entre eles e tratou de buscar pão e sopa para o pobre homem, que deveria estar esfomeado como são todos os pobres no seu pensamento. Ocorre, porém, que o homem não estava em busca de comida. Ele queria falar com o Dono da Casa. "A esmola é ao sábado", disse a cozinheira, mas o miserável senhor insistia em ser recebido pelo dono da casa, afirmando que seu assunto era importante.

Ora, para a cozinheira, uma pessoa pobre não tinha assuntos importantes, tinha apenas fome e era com o alimento dado ou com a esmola que deveria se satisfazer. "As coisas importantes são para pessoas importantes. Tenha juízo, homem. Você quer que o Dono da Casa venha aqui, agora, falar consigo? Nem pense nisso!" (Ibid.), dizia Gertrudes já irritada. Outros criados entravam na cozinha e o homem pedia-lhes que chamasse o proprietário, pois havia um assunto importante a tratar com ele. Mas os empregados não lhe davam atenção, estavam demasiados cansados por causa do jantar. Além disso, reconheciam a hierarquia da casa, eles não estavam em um nível que lhes permitisse chamar o Dono da Casa para falar com um mendigo. E ainda achavam um despautério um homem pobre não saber identificar seu lugar, que era unicamente na mesa para os desfavorecidos. Os criados tentavam chamar-lhe à realidade:

Homem - disse o criado, aproximando-se do pobre - você já viu um senhor deixar as visitas na sala para vir à cozinha falar com um mendigo? Tenha paciência, não pode ser. O mundo é como é. Temos que ter paciência. (ANDRESEN, 2010, p. 70)

A ideia de paciência reaparece na narrativa, porém na voz de uma pessoa da classe desfavorecida, o criado.

“O Mundo é como é” reforça a ideia da qual falamos anteriormente sobre o poder estabelecido como ordem natural. Do mesmo modo que o Dono da Casa estava acostumado ao seu "reino", os empregados mantinham-se em seus lugares na hierarquia pautada nas relações de classe daquele contexto. Não havia lugar para questionamentos, o mundo é assim, uns nascem ricos, outros, pobres, alguns tornam-se empregados e, 
portanto, distinguem-se dos miseráveis. Eles reproduzem o discurso dominante e, de certa forma, agem com um "pequeno poder" sobre os mendigos, afinal nas relações socioeconômicas, eles se diferenciam, não se sentam na mesa dos mendigos, cujo lugar é pouco acima daquele dos cachorros.

Em seus Quaderni del Carcere, Antonio Gramsci vai elaborar uma reflexão acerca do conceito de hegemonia que pode nos auxiliar a compreender o modo como o mendigo é diferenciado pelos criados, apesar de todos serem, se refletirmos bem, parte da classe desfavorecida e explorados economicamente pelos ricos proprietários. As relações entre grupos sociais estabelecem-se por meio do poder que uns exercem sobre os outros. Entretanto, esse domínio ocorre de maneiras distintas, e "não simplesmente por meio de uma organização específica da força, mas por ser capaz de ir além de seus interesses corporativos estreitos, exercendo uma liderança moral e intelectual". ${ }^{104}$ Assim, essa concepção "representa uma base de consentimento para uma certa ordem social, na qual a hegemonia de uma classe dominante é criada e recriada numa teia de instituições, relações sociais e ideias". ${ }^{105}$ Esse conceito verifica-se quando os próprios criados falam da ordem natural do mundo, onde é tido como natural o poder do Dono da Casa. Pelo poder hegemônico das camadas da elite, o grupo dominado interpreta o mundo e o reproduz a partir da perspectiva dos dominantes. Sendo, portanto, coerente os comentários de Gertrudes e do outro criado sobre o despropósito do homem pobre querer dirigir-se ao rico proprietário ou pior: que este se conduzisse à cozinha para encontrar-se com o mendigo e conversar com ele.

A expressão "saber o seu lugar" associa-se com a ideia que vimos sobre a classe subalterna - utilizando-se do termo gramsciniano - ser alijada de poder, logo de voz. Os empregados, por um lado, não reconhecem a legitimidade de um mendigo que tenha algo a falar, afinal sua posição é a mais baixa entre as classes. Ele está em posição de receber esmolas e ter paciência - ou seja, resignação diante de seu status. Notemos que os próprios criados - sendo menos pobres que os mendigos, mais ainda sendo pobres - reproduzem o discurso da classe hegemônica de que seu poder é natural, ou como diz o Dono da Casa, "Todo poder vem de Deus". A própria igreja, considerando o poder que aparentemente exerce nesse contexto, reproduzia - antes do pároco de Varzim - esse discurso, orientando os fiéis a ter paciência e rezar por um mundo melhor, o qual viria pela transcendência,

\footnotetext{
${ }^{104}$ Verbete "hegemonia". In: Dicionário do Pensamento Marxista (Versão Digital). 105 Ibidem.
} 
como propõe a fé cristã, e não por mudanças sociais na realidade concreta do corpo, não da alma.

A partir dessa ideia, não estamos afirmando que os empregados são somente fruto da manipulação intelectual das classes dominante e não pensam por si mesmos. Segundo Gramsci, as classes subalternas têm diferentes visões de mundo, e algumas delas até se contrapõem ao pensamento hegemônico. "O que uma ideologia hegemônica, dominante pode propiciar é uma visão do mundo mais coerente e sistemática que não só influencia a massa da população, como serve como um princípio de organização das instituições sociais". ${ }^{106}$ Nesse sentido, as instituições, como a Igreja, as escolas e os meios de comunicação, refletem o discurso do poder e o disseminam à população. No conto, por exemplo, a religião exerce esse papel fortemente, a ponto de as ideias do novo pároco serem ameaçadoras à ordem existente, pois os aldeões as escutam e refletem de acordo com esse novo discurso, que está claramente em choque com o anterior de aceitação e paciência.

No jantar, quando o mendigo adentra a cozinha e pede para ser ouvido, ele cria uma subversão da ordem natural da sociedade, que impõe aos mais pobres o silenciamento. Se pensarmos, nem os criados têm essa voz, pois eles sabem que não lhes compete falar tal absurdo ao Dono da Casa. Há uma legitimação do poder hegemônico e uma consciência do lugar de cada um dentro da teia de vínculos sociais. Afinal, o trabalho como empregado de uma casa pressupõe o respeito à hierarquia, isto é, àquele que manda e é responsável pelo cargo. Dentro de suas funções, não é aceito expor o rico proprietário aos desejos de fala de um mendigo. Por isso, nenhum criado se dispôs a falar com o patrão acerca da presença do pobre homem.

Do mesmo modo que o pároco de Varzim dá ao leitor material para verificarmos a polarização entre ricos e pobres no conto, a criada Joana também cumpre tal papel. Ela é a única a dialogar com o mendigo que aparece tarde da noite, convida-o para aquecer os pés perto de si, tratando-o com certa humanidade que fora negada pelos outros criados. Afinal, o ato da cozinheira de dar comida ao pobre é uma função prática automática respeitando a ordem do seu patrão, e não uma atitude de altruísmo ou benevolência da parte dela. A velha Joana diz: “- Ai dos pobres! Há sempre uma razão para lhes dizerem que não. Os pobres têm fome e frio e sobretudo estão sós. Se eu fosse nova ia lá em cima pedir por ti. Mas estou velha e já não posso subir a escada" (ANDRESEN, 2010, pp. 71-

\footnotetext{
${ }^{106}$ Verbete “hegemonia". In: Dicionário do Pensamento Marxista. (Versão Digital).
} 
72). Ela não somente legitima de certo modo a voz do pobre homem como se compadece de sua situação. Ela, porém, também já não está ativa em seu papel de criada. Assim como Lobisomem, ela é uma espécie de agregada, uma velha empregada cuja força de trabalho já não é aproveitada, mas convive na grande casa a partir do reconhecimento de seu passado.

Gertrudes mantém sua opinião e diz ao homem para calar-se, pois nenhum criado vai atendê-lo. Em tal recusa, podemos ler que os empregados temem o patrão, afinal seria algo descabido interrompê-lo durante uma ocasião especial em nome dos desejos de fala de um mendigo. São colocados na posição de submissos à hierarquia estabelecida pelo rico proprietário, aceitando o silenciamento de suas vozes. Respeitar o seu lugar é resultado do medo de pôr seus empregos em risco caso rompam a ordem social imposta naquele ambiente, por isso todos negam perturbar o Dono da Casa. Nesse momento, a chuva, que estava fortíssima durante a ocasião, fez com que a luz da residência acabasse e todos despacharam-se atrás de velas para iluminar o ambiente. Esse instante é importante ao enredo, uma vez que releva um caráter especial do mendigo. Para protegerse da tempestade, Joana começa a rezar "A Magnífica”, mas, de súbito, para a ladainha, pois se esquece do conteúdo. Ao fundo, na mesa dos pobres, o homem continua a reza, dizendo

Ele manifestou o poder do seu braço e dissipou os que no fundo do seu coração formavam altivos pensamentos. Depôs do trono os poderosos e elevou os humildes. Encheu de bens os que tinham fome e despediu vazios os que eram ricos. (Ibid., p. 74)

A reza é muito significativa para a trama do conto. Conhecida como "Magnificat", ela provém do Evangelho de São Lucas, no qual se afirma que a oração teria sido dita pelo Espírito Santo à Virgem Maria. Entre suas diversas variações, esse texto pede a glorificação daquele que ora e se coloca diante de Deus em toda a sua humildade, pedindo que seja enaltecido pela misericórdia divina. Aqueles que estão despossuídos seriam glorificados em detrimento daqueles que tudo possuem. Ela faz referência ao acolhimento dos judeus como servos do Senhor, que romperam sua condição de escravos e, livres, foram exaltados. Sendo destinada à Maria, podemos compreender que a oração se refere à humilhação sofrida por seu filho, que seria glorificado por Deus, seu pai. Por extensão, os fiéis a Cristo e a Deus também seriam valorizados em suas situações precárias de fome ou doenças, enquanto os ricos - pobres em caráter - seriam destituídos. 
O mendigo, na mesa dos pobres, completa a "Magnífica" exatamente expondo a parte da exaltação dos pobres e destituição dos ricos, que entram no Reino de Deus de mãos vazias. O discurso religioso, porém, mistura-se ao sociopolítico. Esse homem, que diz vir em nome do pároco de Varzim, cita uma situação de subversão da ordem natural daquele contexto. A glorificação dos humilhados em oposição à privação das posses do rico associa-se à pregação do padre que fala de justiça e de caridade. Apesar de ser privado da autorização da fala, o homem pobre acaba por dizer seu recado por meio da Magnificat. Ele não será ouvido pelo homem rico por todo o jantar, mas sua intenção é análoga ao conteúdo da oração que ele completa diante do esquecimento da velha Joana. Ele, assim, configura-se como a voz que busca romper a imposição do silenciamento, o que contrasta com o medo dos empregados de comunicar ao Dono da Casa a presença dele no local.

Ainda na escuridão, o pequeno João questiona os empregados sobre quem está na cozinha, e um deles explica. A criança não entende por que não lhe atendem. Pergunta ao criado como seria o tal mendigo e ouve "É como os outros pobres, é como a gente de Varzim" (ANDRESEN, 2010, p. 75). O menino decide, então, falar com ele. Entra na cozinha e depara-se com um "homem de rosto jovem e cansado". De fato, ele era semelhante a todos os habitantes pobres da aldeia. Essa descrição lembra-nos um excerto do poema "Esta Gente", publicado no livro Geografia (1967), no qual a voz poética nos diz: "Pois a gente que tem / O rosto desenhado / Por paciência e fome" (ANDRESEN, 2011, p. 458). O cansaço do mendigo não se refere, exatamente, a esforços físicos, mas, sim, à espera por melhores condições de vida. Ele cansado pela paciência que há de se ter no mundo social de exploração estabelecido por homens como o Dono da Casa.

Diante desse indivíduo de rosto desenhado pelo cansaço e pela fome, a criança resolve, então, falar com seu pai, para ver se ele poderia atendê-lo. João diz-lhe para receber o mendigo, pois o que ele tinha a dizer era muito importante. Naturalmente, o pai diz que não é sábado. Os mendigos só recebem esmolas ao sábado afinal. O Bispo então diz ao Dono da Casa para ir ter com o homem, pois "um pobre vem sempre da parte de Deus" (Idem, 2010, p. 76). O menino insistiu, dizendo que o pobre vinha em nome do Padre de Varzim. O rico proprietário ficou consternado. Insistiu que não o receberia, e o padre sabia que somente aos sábados ele oferece esmolas. A criança se dirige chateada à cozinha e avisa que o pai não virá. O homem agradece-lhe. João, então, pergunta-lhe quando voltaria a vê-lo, como se tivesse se tornado amigo do mendigo, que o responde: "Vem ver-me a Varzim". Seu rosto era o sofrimento da aldeia à qual o padre falava da caridade "nua", isto é, a compaixão por alguém que está desprotegido, em estado 
desfavorável, a benevolência para os homens. E não uma esmola de praxe apenas para se manterem as aparências de homem virtuoso.

O pobre indivíduo, diante de toda a situação, agradece a todos e vai embora sem ao menos tocar na comida. Joana, mais uma vez, faz uma reflexão por meio do discurso cristão: "Deus não recebeu as ofertas de Caim", referindo-se à recusa do homem em comer a refeição "de praxe" dada aos deficientes e aos que não podiam trabalhar. Como sabemos, Caim e Abel eram filhos de Adão e Eva. Abel tornou-se pastor de ovelhas, enquanto que o irmão mais velho era lavrador de terra. Ambos os irmãos fizeram oferendas a Deus. Caim levou frutos e o mais novo, primogênitos de suas ovelhas. Porém, o Senhor não aceitou a oferta daquele:

5. Mas para Caim e para a sua oferta não atentou. E irou-se Caim fortemente, e descaiu-lhe o semblante. 6. E o Senhor disse a Caim: Por que te iraste? E por que descaiu o teu semblante? 7. Se bem fizeres, não é certo que serás aceito? E se não fizeres bem, o pecado jaz à porta, e sobre ti será o seu desejo, mas sobre ele deves dominar. 8. E falou Caim com o seu irmão Abel; e sucedeu que, estando eles no campo, se levantou Caim contra o seu irmão Abel, e o matou. 9. E disse o Senhor a Caim: Onde está Abel, teu irmão? E ele disse: Não sei; sou eu guardador do meu irmão? 10. E disse Deus: Que fizeste? A voz do sangue do teu irmão clama a mim desde a terra. 11. E agora maldito és tu desde a terra, que abriu a sua boca para receber da tua mão o sangue do teu irmão. ${ }^{107}$

De acordo com uma das leituras da Igreja Católica ${ }^{108}$, a oferta de Caim estava carregada de arrogância. Apesar de ele ser o primeiro a oferecer a Deus o resultado de seu trabalho - frutos - ele teria dado ao Senhor algo que não lhe custou nenhum esforço, era apenas parte de sua atividade habitual, crendo que Ele aceitaria os termos da oferenda. Abel, por sua vez, teria refletido sobre o que, de fato, Deus esperaria desse ato, preparando com zelo o que ele tinha de melhor, os primogênitos de seu rebanho. Deus, assim, teria aceitado o sacrifício do filho mais novo, despertando a ira do mais velho, que o levou a

\footnotetext{
107 Livro "Gêneses", capítulo 4, versículos 5 a 11. In: Bíblia Sagrada Eletrônica.

108 Convém notar que, ao longo da história, são diversas as interpretações sobre a não escolha ou não aprovação de Deus em relação à oferta de Caim. Optamos por uma das leituras, o que não invalida de modo algum outras formas de se ler o mito. José Carlos Carvalho, em seu artigo "A Figura Bíblica de Caim - um Deus Violento ou a violência de Deus?", afirma que em Gêneses, cap. 4, "O texto só se preocupa com o Caim competidor contra o irmão, isso é que preocupa o autor porque isso é o que preocupa Caim. Caim não está preocupado em oferecer a Deus, está preocupado e a olhar para o que o irmão oferece. Este é o olhar da inveja, desajustado, logo injusto". Nesse sentido, não importaria, de fato, a motivação de Deus ao não olhar para a oferta de Caim, mas, sim, as ações deste diante do que o irmão mais novo ofereceria. (In: Humanística e Teologia, vol. 31, n. 2, 2010, pp. 187-200).
} 
matar o irmão. Além disso, a preocupação dele sobre o que Abel ofertaria poderia também ter despertado a desaprovação divina.

A interpretação luterana nos indica mais elementos de análise da citação da empregada Joana sobre Caim. Nessa perspectiva, o filho mais velho de Adão e Eva expressaria seu desejo de domínio da terra ao oferecer a Deus os frutos da lavoura. Abel, por sua vez, sacrificara os primogênitos de seu rebanho de ovelhas, sinalizando o plano d'Ele em relação ao seu filho, Jesus. Desse modo, Deus julgaria não exatamente as oferendas, e sim o que as motivaram. A oferta em si de Caim não teria representado o respeito e a submissão a Deus, e sim um anseio de dominar e de expressar pelo poder sobre a terra, por isso Ele não a teria aceitado, despertando a raiva do filho mais velho.

Em ambas as leituras, observamos que Joana faz uma analogia à oferta que o Dono da Casa faz aos pobres como algo de praxe, algo mínimo que não significa nada além de reproduzir seu caráter de homem virtuoso, sendo como Caim, uma oferenda fruto da arrogância. Não há, para o homem rico, o zelo e a preocupação com a situação real de fome dos pobres, como houve em Abel quando preparou cuidadosamente sua oferta. Ora, na atitude do rico proprietário estava a noção de superioridade sobre si mesmo e o descaso com os mais desfavorecidos, assim como Deus reconheceu o desdém de Caim. Com base nisso, a velha empregada tece seu comentário, criando uma certa analogia entre o homem pobre e Deus em relação à recusa daquela oferta. Assim, o homem ganha ares de mistério e simplesmente vai embora quando não pode ser ouvido, não aceitando aquilo que era o mínimo feito pelo senhor da casa. A saída do mendigo fecha a parte II do conto. Enquanto ele esperava ansiosamente para ser ouvido pelo Dono da Casa, o destino do Padre de Varzim havia sido decidido em uma negociação determinada pelo proprietário poderoso com a influência do misterioso Homem Importante.

Na parte III do conto, já temos como consumada a ação de deslocamento do novo padre, e o Bispo põe-se a pensar, no carro, sobre toda a ocasião, indo "triste e com a alma pesada" (ANDRESEN, 2010, p. 79). Ele se sentia cansado do mundo, sem forças para lutar contra a intensa argumentação tanto do Dono da Casa como do Homem Importante. Nesse trecho, observamos que o velho homem religioso não se sentia capaz de lidar com o poder oriundo da posição social daqueles homens. Enfraquecido, questionava sua própria fé, afinal Deus parecia-lhe naquele momento “oculto e velado". É interessante notar que ambos os termos se opõem às noções de transparência e nudez que aparecem na obra andreseniana. $\mathrm{O}$ contraste propositalmente criado pela autora nos indica que o Bispo já não se sentia fortalecido em sua crença, Deus lhe parecia distante, a ligação entre 
esse homem e a divindade esmaecia-se. O caráter oculto divino opunha-se também às luzes dos faróis do automóvel onde se encontrava o pontífice em uma espécie de antítese acompanhada por uma subjetivação: a noite escura permeada pelas sombras negras das árvores à margem da estrada expressa, de certo modo, a alma escurecida do Bispo.

Esse contraste em plano metafórico intensifica-se com a aparição, no meio da estrada, de um homem pobre a andar. As luzes dos faróis iluminam o caminho e dele surge o tal andarilho. O Bispo pede ao chofer que pare o carro para que possam levar o mendigo, o qual diz estar em sua rota para a casa do Padre de Varzim. O senhor religioso logo reconhece que o homem pobre era, na verdade, aquele que estivera na residência do rico proprietário pedindo-lhe a palavra. $\mathrm{O}$ pobre pareceu-lhe como toda a gente de Varzim: "Tinha lama nos trapos e a escrita da fome na cara. Nas mãos havia um gesto de paciência. Um gesto muito antigo de paciência" (ANDRESEN, 2010, p. 80).

A visão do mendigo impactou o religioso: "E de repente pareceu ao velho Bispo que todo o abandono do mundo, todo o sofrimento, toda a solidão, o olhavam de frente no rosto daquele homem. Coisa difícil de se olhar de frente" (Ibid.). O homem pobre plasmava em sua aparência toda a privação e miséria que o religioso reconhecia no corpo e na alma dos aldeões de Varzim. Esses elementos obscureciam mais ainda a alma do clérigo, intensificando seu sentimento perante a negociação que acabara de fazer, ainda que por não ter forças diante do poder do capital. Ele, então, diz ao indivíduo que o levaria até a aldeia e que poderia ficar em sua casa naquela noite chuvosa, porém não obteve resposta. O homem pobre tinha desaparecido misteriosamente. Sob a luz do luar, o Bispo e o chofer procuraram o mendigo, mas ele não estava em parte alguma. Havia somente um silêncio, que estava "atento e suspenso" (ANDRESEN, 2010, p. 81).

O silêncio atento para Sophia Andresen é aquele que lhe permite apreender o poema, captar o real e trazê-lo para o mundo da poesia. Ora, o Bispo, sob o silêncio atento, também pôde apreender a realidade. As luzes do carro que iluminavam a estrada e revelavam o caminho também desvelaram metaforicamente a verdade, pois, por meio dessa luz, ele enxergou o mendigo e viu em seu rosto a fome e a aceitação desenhadas, como lemos no poema "Esta Gente". O homem pobre, iluminado pela luz concreta do carro, é, afinal, a própria verdade que se revelava diante do Bispo. Essa imagem pode ser lida a partir da ideia de iluminação para os cristãos, pois o momento mostra uma espécie de revelação espiritual que permitiu ao pontífice entender sua própria postura na negociação sobre o padre de Varzim e, ao mesmo tempo, refletir sobre seu ato. 
Ora, a iluminação ocorre de forma concreta quando o mendigo é visto pelo Bispo, o que promove um instante de iluminação divina, levando-o a questionar sua própria atitude em uma autorreflexão, afinal ele pôde ver, por meio da face do pobre indivíduo, toda a miséria e resignação do povo de Varzim. Ao ser visto, seu rosto revelou a precariedade dos aldeões, dando ao Bispo a exposição do sofrimento, que lhe incita a percepção sobre a situação real e a sua posição diante do ato que acabara de consumar. $\mathrm{O}$ carro, então, dá meia volta e regressa à casa grande, onde ele tentaria cancelar o "negócio" efetivado. Já na presença do Dono da Casa, ele afirma: “- Não sei contar o que vi. Hoje, esta noite, foi acusado um homem justo. Mas o próprio Deus veio ser sua testemunha" (ANDRESEN, 2010, p. 82). Nesse sentido, considerando que o pontífice é um homem religioso, podemos pensar nas ideias de Santo Agostinho sobre a iluminação divina (BOEHNER; GILSON, 2003), segundo as quais o homem obtém o conhecimento a partir de uma revelação imediata de Deus. De certo modo, ele conseguiu compreender a verdade sobre sua ação quando observou a pobreza na face do mendigo, um momento de revelação espiritual.

Naturalmente, o rico proprietário não conseguia acreditar nas palavras do religioso. O que haveria de justo em um homem que busca disseminar palavras contra a ordem natural daquele território? Mais uma vez, o pontífice pôde apreender a realidade e perceber o que estava acontecendo naquela negociação:

O Bispo olhou o Dono da Casa, o dono dos quadros, das pratas, dos campos, das vinhas, dos pinhais e da serra. E viu que era como se todas as coisas que aquele homem possuía tivessem formado à roda dele um espesso muro que o separava da realidade. Ele estava fechado na certeza de seus direitos. (Ibid., p. 82).

A organização natural daquele cenário pautava-se na concepção atribuída pelo poder econômico de que privilégios de poucos são direitos. Por sua vez, o Bispo tinha aceitado julgar o novo padre em troca de um teto restaurado, o qual simbolicamente pertence à Igreja da Senhora da Esperança.

As relações sociais que são organizadas na localidade de Varzim dialogam, como vimos, com a ideia de Hegemonia trabalhada por Gramsci (1978, pp. 14-15), trazendo um grupo subjugado que, comumente, adota a visão do mundo da camada dominante, ainda que isso esteja em total contradição com a sua condição de vida. Haveria, assim, um contraste entre duas concepções de realidade que coexistem, mas apenas uma mantém-se dominante. No nosso contexto específico, a organização dada como natural - a 
hegemônica - é rompida primeiramente pelo padre de Varzim. Em um segundo momento, temos o pobre homem misterioso, que incita o Bispo a desvelar a perspectiva do Dono da Casa.

Evidentemente, o Dono da Casa não reconhecesse seu papel nessa concepção dominante de realidade, refutando o uso do termo "vendido" usado pelo Bispo. Em seu raciocínio, ele somente fez o que era de praxe para alguém em sua posição social: deu uma esmola, uma doação para o restauro da igreja. Em tal recusa, observamos o "espesso muro" (ANDRESEN, 2010, p. 82) que o religioso observara em torno do rico homem, isolando-o convenientemente da verdade. O status socioeconômico do grupo dominante inverte o conceito de privilégio, confundindo-o com o de direito. O muro surge como o véu de Pequenos Burgueses, que ofusca a visão, que separa a realidade concreta do pensamento hegemônico do grupo dominante. O muro é ainda concretamente marca de separação, ele envolve a família em sua grande casa - simbolizando seu poder e seu status - e a distancia da aldeia empobrecida, sendo um modo de marginalizar, de segregar. O proprietário não queria enxergar a realidade das claras palavras do pontífice. Em sua recusa, está também a consciência de sua ação, pois "ele não tinha nenhuma intenção de se confessar. Era mesmo como se ele tivesse perdido ou rejeitado há muito tempo a possibilidade de se reconhecer a si próprio" (ANDRESEN, 2010, p. 83). Assim, ele recebeu com indignação a atitude do Bispo, uma vez que ele "às regras da boa educação respondia com problemas de consciência" (Ibid.).

O seu caráter e o ethos esperado pela sua posição social confundiam-se na reação do rico homem. Por um lado, queria aceitar de volta o dinheiro doado e responder cruamente ao Bispo, por outro, sua educação não lhe permitiria isso, afinal tinha uma boa reputação entre os aldeões e a Igreja. Resolvera, então, convocar o Homem Importante, afinal ele também havia dado um cheque. Para a surpresa de todos os criados e do Dono da Casa, o hospede misterioso sumira. Não se encontrava mais nem o homem, nem o cheque por ele dado e recusado pelo Bispo nesse momento. Os empregados passam a procurar incessantemente o objeto, mas o religioso vai embora, sentindo-se aliviado de desfazer a tal transação.

A história encerra-se com duas falas que revelam o caráter crítico do conto. No desaparecimento tanto do Homem Importante como de seu cheque, os criados da casa passam a elucubrar o que tinha acontecido nessa anormal ocasião. A velha Joana diz: "Talvez ele fosse realmente o Diabo". Nos tempos que correm pode bem ser" (Ibid., p. 87). A cozinheira, mais incrédula, responde “- Nos tempos que correm já não há Deus 
nem Diabo. Há só pobres e ricos. E salve-se quem puder" (Ibid.). Sua fala ocorre enquanto ela limpa o chão da cozinha das pegadas do misterioso mendigo. A polaridade entre o bem e mal parecem, aos olhos de Gertrudes, uma questão econômica somente, e não um assunto da fé. Essa personagem demonstra, em um primeiro momento, sua preocupação em cumprir sua função, rejeitando o pobre homem que lhe significava mais trabalho pela sua sujidade. Ela, no entanto, reconhece em sua reflexão a tensão entre as camadas favorecidas e as subalternas e finaliza sua percepção com "salve-se quem puder", ou seja, não há o que se fazer diante dessa ordem social tida como natural. Quem conseguir escapar dela, está salvo, mas os que não podem mantêm-se na organização pautada pelo poder de uns e a exploração de outros. Ela é, assim, mais crítica diante da situação socioeconômica em que se encontra.

Visto como uma parábola, o conto, na realidade, delineia-se como uma análise crítica do contexto observado em uma sociedade de classes, na qual há ricos e empobrecidos. A dicotomia entre bem e mal associa-se à questão socioeconômica de polaridade entre as classes sociais. Sophia Andresen busca trazer pela personagem do Dono da Casa o modo de pensar da elite rural que procura reproduzir a estrutura social pautada no poder de gerações, estando habituada a uma ordem naturalizada por todos desde os mais favorecidos até os mais miseráveis, o que dialoga com o conceito gramsciniano de hegemonia, como observamos. As pessoas pobres da aldeia de Varzim tendiam a procurar na religião uma esperança para os malefícios da vida miserável em que viviam, mas a aceitam como estrutura normal, em uma espécie de alheamento da condição real criada pelo poder do capital, o que aparece no livro a partir do conceito de "paciência". Os habitantes estavam resignados à sua posição social e esperavam mudanças em âmbito espiritual, por meio das orações até que houve a inversão do discurso instigada pelo novo pároco, expondo de algum modo a tensão que existe entre as classes.

Há, nesse contexto, um grupo de personagens que formam a polaridade entre os grupos sociais na narrativa. E tal oposição vai ser explorada por Sophia de modo a criar, pelas alegorias do bem e do mal, um conflito entre riqueza e pobreza. No âmbito do bem, temos, naturalmente, o Padre de Varzim, o primo Pedro, o mendigo misterioso - os desfavorecidos - e João, filho do rico proprietário, o qual aceita o homem pobre e liga-se a ele de alguma forma. No campo dos ricos, temos o Dono da Casa, as referências a seus antepassados e o Homem Importante. Podemos perceber que os empregados da casa ora 
acentuam um lado, ora expõem o outro, o que é verificado no modo como Joana e Gertrudes tratam diferentemente o mendigo com roupas sujas.

Tal polaridade é ainda intensificada pela estruturação temporal do texto. Clara Rocha observa que "para dissimular a linearidade do tempo do discurso e facilitar a si mesma a narração de eventos simultâneos, a narradora recorre à habilidade literária de instituir diversos planos, deixando um em suspenso para passar a outro [...]" (1980, p. 48). Esses campos acabam por convergir e, depois, distanciar-se. O primeiro plano corresponde à parte inicial das elucubrações sobre o Padre de Varzim e o teto da igreja, cujo ápice está na chegada do Homem Importante e na sua argumentação favorável ao Dono da Casa, fortalecendo os aspectos disfóricos do conto, como a injustiça e a força do capital.

O segundo plano inicia-se com a chegada do pedinte e a sua tentativa de falar com o rico proprietário. Temos, assim, a polaridade entre ambos, como verifica Rocha (Ibid.). As personagens - lidas como alegorias - trazem os conceitos de rico/poderoso versus pobre/oprimido. Podemos interpretar como ápices desse plano a intervenção malsucedida do filho do Dono da Casa, pedindo que o pai atendesse ao pobre, e, posteriormente, o fato de o mendigo não tocar na comida. Ambas as ações criam a polaridade entre o homem poderoso e o homem oprimido, lidas alegoricamente como o conflito entre a riqueza e a pobreza - financeira e moral.

O terceiro plano promove uma convergência entre os anteriores a partir da consciência do Bispo sobre a atitude que tinha tomado. Sua reflexão expõe o caráter dos homens poderosos versus a fragilidade da velhice, opondo a riqueza financeira à pobreza moral. O ápice desse plano é justamente o encontro com o mendigo misterioso e a posterior tomada de consciência do Bispo. Nesse plano, as alegorias e símbolos que formam o conto dialogam em oposições. Temos o âmbito da riqueza material/pobreza de caráter lido como o "mal" e condensado na imagem do Diabo (Homem Importante) e o campo da pobreza material/ riqueza de caráter, representando o "bem" e consolidado na imagem de Deus (o mendigo misterioso). Rocha afirma que "a instituição de diversos planos põe em relevo a existência de várias forças actanciais, ao mesmo tempo que a convergência ou afastamento daqueles exprime a aliança ou irredutibilidade destas últimas" (1980, p. 48).

Ocorre, desse modo, uma série de oposições em níveis distintos do conto. Temos o próprio conteúdo, que revela a oposição central entre riqueza e pobreza, a qual é delineada a partir de antíteses e contrastes criados no enredo. Além disso, a estrutura 
formal também se constrói com base na ideia de polaridade entre as partes I e II. Rocha observa que esse modo formal refere-se à preferência de Sophia Andresen pela lógica paralelística, o que ela obtém com os planos paralelos de ação (1980, p. 49). A nossa leitura, entretanto, ressalta que a noção de tensão presente por meio da forma e do conteúdo é um modo de expor a temática da desigualdade social característica do contexto rural português, seja do início do século XX, seja do próprio tempo da autora.

Portugal apresentava-se ainda nas décadas de 1950 e 60 como um país basicamente rural, com altos índices de pobreza. O campo era o espaço onde habitavam camponeses jornaleiros, como vimos nos romances de Oliveira, e pequenos e microproprietários de terra, os quais também se mantinham na miséria, como bem ilustrou o casal Luciano Taipa e Palmira em Casa na Duna. Estima-se que a população rural compunha cerca de 50 a $60 \%$ do número total de habitantes portugueses no período e, de acordo com Manuel Carlos Silva, a maioria do grupo campesino "mostrou, por mediação da Igreja e seus representantes locais, uma considerável anuência passiva com a 'élite governante salazarista'" (1987, p. 408) e, por extensão, com a própria elite rural, com a qual mantinha uma relação de dependência econômica.

Nesse contexto, entendemos a noção de paciência trazidas no conto. Etimologicamente, os termos patientia, patientiae referem-se à ação de sofrer, de suportar e de tolerar, por isso pensamos na ideia de resignação. Esses camponeses vivem seu cotidiano submetidos a ordem social da exploração, mas estão à espera de que a situação mude, por isso rezam, como sugere o conto. Ser paciente, desse modo, faz-nos pensar, por um lado, na aceitação da condição, mas, por outro, no ato de esperar que haja modificações nessa estrutura. É com base nessa perspectiva que Sophia Andresen nos apresenta, a partir da polaridade entre mal e bem, um conflito presente em âmbito socioeconômico caracterizado pelo domínio da camada favorecida rural sobre a grande maioria da população, encontrada em condições de privação grave, "sem infraestrutura e sem previdência social" (SILVA, 1987, p. 410) e parte de sua passividade diante da situação pode ser explicada pela influência dos Aparelhos de Estado, como a Igreja Católica, e o analfabetismo majoritário entre esse grupo (Ibid., p. 411).

Há também, em partes, certa influência das relações paternalistas presentes no campo, ou o "patrocinato", como vimos no capítulo 2 ao abordar as relações sociais na quinta de Mariano Paulo. Este configura-se como "mecanismo de vinculação pessoal e/ou dependência do cliente em relação a pessoa socialmente influente denominada patrono" (Ibid.). Tal modo de poder, conforme analisa Silva, "é, sem dúvida, uma base que permite 
aos seus detentores não só dispor das fontes de riqueza, entre as quais a força de trabalho, mas também organizar a distribuição dos bens de consumo, o que, consequentemente, reforça a sua própria posição económica" (Ibid.). Desse modo, as relações entre patrão e aldeões, muitas vezes baseadas no patrocinato, eram um modo de forte influência destes, mantendo o clima de resignação diante da precarização enfrentadas. Podemos ilustrar esse modo de manutenção de poder tanto na personagem de Mariano Paulo como no Dono da Casa. O primeiro expunha certa preocupação com os camponeses, sobretudo considerando a derrocada de sua propriedade. Além disso, há trechos importantes que mostram certa atitude paternalista dos Paulos, como nas ocasiões de festas. O Dono da Casa, por sua vez, mantém um aspecto paternalista através da imagem que cria de generoso e benevolente com os pobres e com a Igreja. Desse modo, forma-se uma ideia de proteção vinda dos patrões, o que assegura o poder destes em detrimento das condições de vida dos jornaleiros, ganhões e outros trabalhadores rurais.

Em "O Jantar do Bispo", Sophia apresenta uma crítica ampla que vai além da polaridade bem versus mal lida por muitos estudiosos. Encontramos uma reflexão da autora sobre a noção de humanidade que seria fruto da ideologia cristã e, ao mesmo tempo, sobre o corrompimento de valores de certos membros da Igreja, ilustrados na tensão interna do Bispo em sua posição na "negociação" com o Dono da Casa. Eduardo Prado Coelho observa, em uma entrevista com a autora, que na sua obra haveria ora uma “exigência de uma certa dimensão ritual, quase intemporal”, ora uma "tensão política que, em princípio, poderia estar em contradição com isso, mas que está sempre presente" (ANDRESEN, 1986, p. 73). Diante disso, ela lhe responde "Penso que uma educação católica cristã predispõe para a política na medida em que nos responsabiliza” (Ibid.). Para ela, o cristianismo cria "uma exigência em relação aos outros" (Ibid.).

A criação religiosa, desse modo, foi uma das formas como a escritora pôde apreender a relação do homem com seus semelhantes, o que a teria levado, como muitos outros católicos, a um posicionamento político mais ativo (ANDRESEN, 1986, p. 74). De fato, na década de 1960, muitos católicos apoiam o Partido Comunista Português (em maioria) e outros, o grupo socialista, em um movimento que já se observava desde o final dos anos 1950, quando o aparente posicionamento favorável ao Estado Novo da Igreja Católica em Portugal começou a se fragmentar, conforme indica o sociólogo Nuno Medeiros (2015, p. 138). Assim,

É inegável que sempre houve críticas internas e uma visão dissidente entre os católicos portugueses, desde o início da ditadura, com a 
condenação da repressão política e a reação contra a persistente desigualdade social. Além disso, a participação católica no universo de ação social e política já pôde ser vista na interconexão entre a classe trabalhadora, o sindicalismo e a presença organizada católica. Esse movimento teve suas raízes no século XIX e viu novos desenvolvimentos nas décadas de 1930, 1940 e 1950, inclusive no universo da classe trabalhadora e dos sindicatos. (Ibid., tradução nossa)

Apesar de existir a discordância interna ao grupo católico, a manifestação de vozes contrárias e a sua respectiva força de amplitude foram controladas e dissipadas publicamente com um relativo sucesso, segundo Medeiros, tanto pelo poder da Igreja quanto pela repressão do próprio regime, o qual tomou "medidas firmes para suprimir a independência de movimentos católicos que expressaram eficácia na sua organização ideológica e politicamente" (Ibid.).

No fim da década de 1950, ocorrem mudanças nesse quadro. Em 1957, acontece a campanha do militar Humberto Delgado para a presidência, da qual Sophia Andresen participa ativamente. Porém, por meio de fraude, ele é derrotado, e pela sua oposição é perseguido constantemente pela PIDE. Além disso, em 1958, deflagram-se as guerras coloniais, o que promove uma grave desestabilização do poder autoritário do Estado Novo. Quatro anos depois, Delgado volta a se opor ao regime por meio de um golpe militar, que fracassa. Exilado, o militar é morto no ano de 1965 por agentes da polícia política, em sua tentativa de retornar a Portugal para encontrar-se com opositores pela fronteira espanhola na cidade de Olivença, segundo Jorge Fernandes Alves (1998, pp. 35).

Medeiros observa que esse é o cenário “contra o qual, no início da década de 1960, um catolicismo de oposição, em uma minoria, em contraste com um catolicismo de situação $^{109}$, em sua maioria, para quem a legitimidade foi muito importante, aumentou e cresceu progressivamente, tornando-se mais ativo" (2015, pp. 138-139, tradução nossa). Nesse âmbito, muitos religiosos passam a apoiar os movimentos comunista e socialista na tentativa de se defender uma ação contra a intensa miséria que abarcava o país, sobretudo na zona rural portuguesa. Sophia Andresen e outros intelectuais expressam apoio ao grupo socialista e, em 1966, ela assina um protesto, a "Carta dos 101 Católicos", no qual são denunciadas questões ligadas à guerra colonial.

${ }^{109}$ Destaques feito pelo autor. 
A autora afirma que seu engajamento político nasce de uma consciência de "uma grande miséria muito patente" observada já na infância, o que se tornou para ela uma “interrogação enorme, um escândalo” (ANDRESEN, 1982, p. 3). Segundo ela,

[...] Em determinada altura e por influência de pessoas com quem convivi, esse escândalo foi-se estruturando e tomando forma mais definida. O que era só uma indignação ou um espanto ou uma angústia foi-se transformando numa escolha política. A partir de certo momento pensei ser necessária uma luta pela justiça que passava pela política [...] (Ibid.)

Para muitos críticos, esse momento passa pela publicação de Contos Exemplares e de Livro Sexto, mas ela afirma que sua poesia já demonstra um viés politizado antes desses volumes. Entretanto, podemos observar naquele uma acentuada abordagem de conteúdos de caráter social ligada a uma concepção do humanismo cristão, de forma a unir os valores estéticos da sua obra à sua mundividência, que contempla o fazer poético conectado e atento à realidade do mundo e, consequentemente, à do homem. Helena Malheiro observa que é "a tomada de consciência do 'espantoso sofrimento do mundo' contra o qual é preciso lutar, é a 'coragem e a alegria do combate desigual' expressa pela autora na dedicatória" (2008, p. 86) do livro.

Nesse sentido, a aproximação estabelecida em “O Jantar do Bispo" entre um pensamento político, valores clássicos e uma reflexão cristã configura um modo de procura pelos ideais de justiça na obra andreseniana e de denúncia da desigualdade social vivenciada no contexto português. O conto expressa uma leitura acerca do conflito de classes, que cria condições de vida miseráveis a uma grande parte da população, ilustrada no povo de Varzim. Há ainda a tensão entre poder e silenciamento, expressa pela ação sem sucesso - do mendigo misterioso. Sua voz e suas necessidades não são legitimadas dentro de uma hierarquia determinada pela camada dominante, a qual tem ecos na expressão dos criados da casa grande, revelando o caráter hegemônico do discurso daquela.

Novamente observamos, por meio da personagem do homem pobre, que o grupo desfavorecido não consegue estabelecer sua fala nem sua posição, sendo oprimido diante da tentativa de expor-se, de reivindicar direitos. Tal silêncio imposto aflige tanto o homem misterioso como o padre da aldeia, o qual sofreria uma mudança resultante do questionamento da ordem social estabelecida há muitas gerações. Dessa maneira, delineia-se no conto, por meio de símbolos e alegorias, um posicionamento diante do 
contraste determinado pelo poder econômico e pelo domínio social que ele possibilita, opondo-se agudamente às noções de harmonia e justiça buscadas por Sophia em sua obra.

\subsection{O superficial, a mentira e a maldade: 0 mundo das aparências em "A História da Gata Borralheira"}

A oposição entre classes volta a ser retomada por Sophia Andresen na sua prosa por meio de um viés simbólico em "História da Gata Borralheira", conto de abertura de Histórias da Terra e do Mar (1984). Como o próprio título indica, o texto faz referência à história infantil da jovem Cinderela, a filha de um fidalgo viúvo. $\mathrm{O}$ homem casa-se pela segunda vez também com uma viúva, a qual tem duas filhas. As três mulheres passam a maltratar Cinderela, obrigando-a a limpar a casa e transformando-a em uma criada. "Borralheira" é relativo à palavra "borralho", lugar onde se acumulam as cinzas de uma lareira ou de um forno. Logo, a criada borralheira é aquela que vive junto ao borralho, isto é, ao fogo, a um forno. É um dos contos infanto-juvenis mais conhecidos e apresenta diferentes versões. Sua origem é questionada, no entanto, a narrativa já era contada quando foi registrada na China, no século IX d. C., segundo Bruno Bettelheim (2002, p. 252). No Ocidente, a versão mais disseminada é a do escritor francês Charles Perrault, de 1697, e a dos irmãos Grimm, de 1812.

O conto ${ }^{110}$ é famoso por trazer a trajetória da bela jovem, de cerca de 15 anos, que consegue superar a perseguição imposta pela madrasta, casando-se com o príncipe do reino. O ponto de mudança da condição de Cinderela dá-se em uma noite em que ocorreria um baile para o qual foram convidadas "todas as pessoas de qualidade" (Perrault, s/d, p. 06). Naturalmente, a menina tratada como criada não imaginou que poderia ir a tal evento, usado pelas irmãs "postiças" como modo de provocação e humilhação. A bela jovem auxiliou as garotas malvadas a se arrumarem, mas, após a partida das três, pôs-se a chorar de tristeza. Nesse momento, aparece a fada-madrinha, personagem misteriosa que torna possível a presença de Cinderela no baile a partir de magia: transforma uma abóbora em carruagem para conduzi-la, ratos em cavalos, uma ratazana em cocheiro e ainda lagartixas em lacaios para auxiliá-la na descida de seu transporte.

\footnotetext{
110 Nossa leitura é feita a partir da versão de Charles Perrault apresentada nos livros: MACHADO, Ana Maria (apresentação). Contos de Fadas: de Perrault, Grimm, Andersen \& Outros. Rio de Janeiro, Zahar, 2010 e A Gata Borralheira por Charles Perrault. São Paulo: Melhoramentos, s/d, livro XXII. Disponível em: https://books.google.pt/books?id=n9fD1F3fK8sC\&printsec=frontcover\&hl=ptBR\&source=gbs_ge_summary_r\&cad=0\#v=onepage\&q\&f=false. Acesso em 12 mar 2018.
} 
A história ainda traz a transformação da gata borralheira em uma linda dama vestida "de brocado de ouro e prata" cheio de pedras preciosas e, para os pés, um belo par de saltos de cristal. A contrapartida de tal magia seria o retorno de Cinderela à meia-noite, quando todos os efeitos se desfariam. Feliz, ela se dirigiu ao baile, onde foi recebida pelo príncipe, conquistado naquele momento pela beleza dela. Todos falavam da estonteante moça de origem desconhecida. Ele a convidou para uma segunda festa, à qual a menina compareceu novamente transformada pela fada-madrinha. No segundo dia, porém, ao sair do evento às pressas, para respeitar o prazo da magia, perdeu um dos sapatos de cristal na escada, seria o calçado mais bonito do mundo.

Dias depois, o príncipe proclama que se casaria com a bela dama e mandou seus empregados calçarem o sapato em todas as moçoilas da nobreza para achar sua amada. Como não a encontrou, estendeu as buscas às meninas da aldeia. Finalmente, na casa de Cinderela, as irmãs feias provam o calçado, que não lhes serve. A menina pede para provar o sapato, fazendo-o ao som dos risos provocadores das três mulheres. Porém, o empregado fica encantando quando percebe que o belo calçado serve perfeitamente na bela jovem. Mais surpreso ainda fica quando ela mostra o outro exemplar. Assim, os dias de criada da menina borralheira acabam e ela se casa com o príncipe. Em um ato de bondade, a moça ainda providencia o casamento para as duas meias-irmãs com nobres da corte.

O conto traz a superação de um contexto de humilhação e maldade por meio de valores como a bondade, o que permitira à jovem subjugada a atenção e o cuidado da fada madrinha. Ela "é a catalisadora dos desejos da menina e também juíza, pois é ela - sua presença mágica e protetora - que oferece as condições necessárias para que Gata Borralheira possa ir ao baile", conforme analisa Paola Poma (2008, p.220). Há, desse modo, uma moral na história, mostrando que a resiliência, a delicadeza e benevolência da menina superam a beleza e ela pôde, por ter um bom caráter, ter seu destino modificado. O sapato de cristal simboliza essa moral, pois o par fora o único elemento da magia que não desapareceu, o que tornou possível ao príncipe achar sua amada. A madrinha reconhecera a doçura nas ações da moça e fez dela a princesa do reino. A beleza, cerne das preocupações das irmãs postiças, seria algo importante às mulheres, mas nunca um valor nobre como a bondade e a virtude.

Reconhecida por escrever histórias infantis, é interessante o fato de Sophia Andresen trazer em suas Histórias da Terra e do Mar uma releitura de "A Gata 
Borralheira", pois o livro, em princípio, destina- se a um público adulto. ${ }^{111}$ Marcado por uma "carga poética", nas palavras de Maria Alzira Seixo, e de "investimentos simbólicos" (1985, p. 92), a história da menina Lúcia - a gata borralheira andreseniana - permite uma leitura da temática social já abordada pela autora em seus Contos Exemplares e na sua obra lírica. Segundo a crítica, essa seria uma versão "híbrida" do conto de fadas, trazendo uma história de "alienação" (Ibid., p. 93), ou, como afirma Poma, uma "tragédia social" (2008, p. 222). Enquanto Cinderela, uma fidalga, aceitava com bondade e resignação os maus tratos da madrasta e suas filhas, sendo colocada numa posição vista como inferior, Lúcia é uma modesta jovem que se encanta com um mundo ao qual não pertence. Verificamos, desse modo, um enredo que busca abordar a questão das aparências de uma camada favorecida e certo desejo por ascensão social a qualquer custo de uma pessoa da classe vista como inferior.

Marie Louise von Franz, especialista junguiana em interpretações de mitos e contos, afirma que o gênero "conto de fadas" é "a mais pura e simples expressão do inconsciente coletivo do processo psicológico", sendo uma espécie de espelho dos padrões psíquicos nos quais determinados grupos se fundam (1985, p. 05). O nosso conto, entretanto, é uma recriação, e o mundo de fantasia nele elaborado revela, na realidade, um olhar para outro tipo de padrão: os padrões socioeconômicos em que as sociedades de classe se baseiam. Escrito em 1965, é dividido em duas partes. A jovem protagonista aparece "debruçada sobre o tanque redondo", mirando seu reflexo extasiadamente numa noite que "caminhava como uma rapariga descalça", "leve e lenta sobre a relva do jardim" (2017, p. 05). A narradora apresenta-nos uma breve descrição da residência vista por esse jardim, "uma casa grande cor-de-rosa e antiga". A noite era de festa, então daquele local viam-se as luzes e "a música misturava-se com o baloiçar das árvores" (Ibid.). O que se descreve é o baile, povoado por meninas que dançavam, fazendo seus vestidos moveremse como se flutuassem. Era um cenário que parecia feérico e irreal nas palavras da narradora, suscitando "uma alegria rápida e agitada, desgarrada e passageira, um pouco triste e cruel" (Ibid.).

O ambiente mágico da casa ressalta a antítese entre a alegria e a tristeza, que se deve à Lúcia, de 18 anos. Ela estava pela primeira vez em um baile e vinha acompanhada de sua tia, que era sua madrinha. Com os brincos a tilintar, a tia atravessou a sala da festa em direção aos donos da casa, enquanto a menina parecia sentir-se deslocada, "um pouco

\footnotetext{
${ }^{111}$ Em Portugal, o conto é trabalhado nas escolas a partir do 7o ano, equivalente ao 8o ano do Ensino Fundamental II brasileiro, e no nível secundário, equivalente ao Ensino Médio brasileiro.
} 
entontecida por tantas caras desconhecidas e tantos vestidos de tantas cores e pela profusão de vozes e flores e luzes e perfumes [...]" (Ibid., p. 06). Pela enumeração sem pontuação, um traço presente também na lírica andreseniana, conseguimos perceber, por um lado, o ritmo agitado do evento e, por outro, a sensação de tontura da protagonista.

A tia apresentou Lúcia aos anfitriões, que lhe deram uma atenção breve e superficial. Conheciam Pedro, o pai da menina e primo da madrinha. Fizeram-lhe perguntas de praxe sobre o pai e logo se entretiveram com outros convidados que chegavam à casa. A filha da dona foi apresentada à menina e a conduziu para a sala de danças, povoada com pares que se movimentavam e se multiplicavam "nos enormes espelhos esverdeados" (ANDRESEN, 2017, p. 07). Em seu papel de jovem anfitriã, a filha da dona apresentou Lúcia às amigas, que se dirigiram a ela com indiferença e "ar alheio". Voltaram a conversar como se ela não estivesse lá e movimentavam-se agitadamente, como toda a noite parecia estar.

$\mathrm{Na}$ breve narração sobre as personagens, o narrador vale-se de termos como "indiferença", "distraído", "ar alheio", indicando uma certa superficialidade nas relações travadas naquela ocasião. Havia muitos convidados, muito movimento, e os anfitriões mal se aperceberam da presença de Lúcia, que olhava às garotas na sala "com um misto de temor e fervor. Pareciam-lhe todas bonitas, animadas por uma vida rápida e segura, e tinham faces rosadas como um fruto e um agudo brilho nas vozes metálicas" (Ibid.). Novamente, uma espécie de antítese nas sensações da protagonista, que se sentia amedrontada pelo contexto em que fora recebida indiferentemente, mas olhava-o com admiração e êxtase. Tentou conversar com as meninas durante uma pausa da dança, porém foi ignorada. Quando a música e os movimentos retornaram, o grupo se desfez, todos começaram a girar em pares, porém Lúcia ficou sozinha, ninguém a tirou para dançar. O misto de alegria e tristeza, de tremor e de fervor intensifica os sentimentos de solidão e deslocamento da menina, que parece não fazer parte daquele cenário.

Tal cena nos introduz a um clima de humilhação e vergonha que Lúcia vai enfrentar naquela ocasião, o que será essencial para a sua transformação de jovem pobre à menina "amadrinhada" rica. Ignorada pelas pessoas daquela classe social, a garota se isola em um canto, de onde observa outras moças a olharem-na firme e curiosamente, questionando-se "de onde ela viria” (ANDRESEN, 2017, p. 08). Essa pergunta, que poderia parecer simples, é, na realidade, um indício da polarização entre dois grupos sociais distintos: Lúcia era uma "intrusa" no círculo da autocracia. O olhar frio das garotas 
que queriam saber a origem dela, de fato, expunha-a ao desprezo da camada favorecida sobre aqueles que não pertencem a ela:

E ambas poisaram nela um olhar duro, como se Lúcia fosse uma intrusa e elas a quisessem pôr fora da sala, empurrando-a com o olhar; como se elas, afirmando não saber quem ela era, a atirassem para o mundo das coisas inexistentes (Ibid.).

A pobre menina lidava, assim, com sua solidão diante do desprezo cruelmente curioso dos olhares à sua volta, marcando que sua presença era algo de incomum, como se fosse usurpar o lugar de quem realmente merecia estar naquele baile.

Ao isolar-se, Lúcia passa por um espelho e olha a sua vestimenta, que, na sua opinião, era feia. Ela não tinha um traje de baile e utilizou um antigo vestido da sua madrinha. Nesse trecho, ocorre uma pausa na narrativa do evento, e o narrador nos coloca diante do dia em que a tia/madrinha mostra a Lúcia que lhe poderia "arranjar" um velho vestido lilás. Logo no momento em que o viu, a menina rejeitou-o, pois a cor lhe caía mal. Mas a madrinha garantiu-lhe que naquela idade tudo lhe cairia bem e ordenou que costureira o ajeitasse. A menina calou-se depois de tentar mais uma vez dizer que a cor não lhe ficava bem, enquanto a tia insistia no uso.

Apesar de ter um vestido refeito que não a agradava, era um sonho para Lúcia ir ao baile. Era como se esse evento permitisse que ela saísse da sua dura vida. Vinha de uma boa família, mas vivia com o pai viúvo que era "arruinado", além de ter dois irmãos "a quem a falta da mãe e o desinteresse das criadas velhas tornaram quase selvagens" (COELHO; AZINHEIRA, 1995, p. 12). Há novamente um contraste entre a sua vida real e a "vida do baile", ou seja, o que ela imagina sobre aqueles que frequentam tais festas. Lúcia cultiva o misto de curiosidade de ir a um baile e, ao mesmo tempo, o anseio de pertencer àquele grupo que frequenta sempre essas ocasiões: “Às vezes, no colégio, algumas das suas amigas falavam de um mundo de festas e divertimentos, um mundo onde tudo era fácil e todas as pessoas eram ricas" (ANDRESEN, 2017, p. 10). O baile, pois, parecia-lhe uma porta para tal mundo.

O desejo de adentrar nesse mágico grupo não lhe permitia negar o convite feito pela tia, mas ela se sentia totalmente desconfortável com um velho vestido lilás rearranjado. Tentou suscitar na madrinha a ideia de um novo traje, mas a tia insistia naquele antigo. Além disso, ela tinha outra preocupação: precisava de sapatos de salto e não tinha nenhum. A tia/madrinha não lhe providenciou um par e ela não podia pagar por 
eles, pois o que havia nas lojas da cidade eram "todos terrivelmente caros" (ANDRESEN, 2017, p. 11). A resposta que conseguiu pensar foi procurar um par em sua casa. Os saltos

foram, após algumas horas de desesperada impotência, encontrados numa arca, no sótão, juntamente com outros, igualmente uma recordação de um passado sem volta. Estavam num estado miserável: de um azul manchado e empalidecido, rotos e deformados, foram, mesmo assim e embora largos, o conjunto possível para o vestido lilás que arrastava no chão, tapando a miséria que eles representavam (COELHO; AZINHEIRA, 1995, p. 12).

Os sapatos ilustravam, pelo seu estado, a pobreza da vida de Lúcia. Ela os vestiria largos do mesmo jeito, pois, assim como os seus pés não cabiam naquele calçado, a menina também não se encaixava naquele mundo de divertimento que tanto admirava. Nesse sentido, conforme observa Poma,

Todo o deslumbramento existente na história de Perrault da beleza das roupas, do mundo encantado da fada madrinha, ao símbolo do par ideal - o sapatinho de cristal - na narrativa de Sophia Andresen passa a ser uma referência social da falta. Lúcia não tem condições financeiras para ter um belo vestido, o que a impossibilita de ir ao baile, já que a roupa sintetiza, aparentemente, as classes sociais (2008, p. 223).

De volta à narrativa do baile, observamos, então, uma menina completamente deslocada e sentindo-se diminuída, seja pela sua vestimenta - fora de moda e rearranjada -, seja pelo seu par de saltos - que expunha sua origem humilde e ainda estava largo em seus pés -, seja pelo grupo de garotas, que a todo momento indicava de forma cruel que Lúcia não pertencia àquele lugar. Para Poma,

o sapato, simbolicamente, [é] a confirmação ou a prova da identidade da pessoa a que pertence, e, portanto, garantia do despertar de um desejo, visto a sua beleza ser a continuidade da beleza e da delicadeza feminina; no caso de Lúcia os sapatos, que não lhe pertencem, revelam o deslocamento social e a necessidade do vestido ser bem longo para camuflá-los. (Ibid.)

A menina, vexada, resolve ir ao quarto de vestir, para passar mais rouge no rosto, pois estava pálida. Naquele local, mais uma vez foi apontada e humilhada pelo seu traje.

- Quem é aquela rapariga com um horrível vestido lilás?

- Não sei, pensei que já não havia ninguém capaz de se vestir de lilás.

- Coitada, tenho pena dela. Deve ser um vestido emprestado. (ANDRESEN, 2017, p. 13) 
Havia, porém, um olhar de atenção à Lúcia que a salvava dessas críticas cruéis: “- Vocês são más e snobonas. O vestido é feio, mas ela é bem bonita - atalhou a terceira rapariga, que tinha estado calada" (Ibid.).

A jovem menina, que vestia um traje belo de chiffon cor-de-rosa, rompeu o ambiente de condenação e desprezo em que Lúcia estava inserida. Elogiou-a sobre o tom de pele e a aconselhou a não se olhar no espelho de moldura dourada que a empalidecia ainda mais. Ela adverte a pobre jovem: “- Sabe... é preciso não dar importância a este gênero de espelhos. São como as pessoas más, não dizem a verdade” (Ibid., p. 14). Ela ainda observa: “- Sabe [...], não sabemos ao certo o que querem os maus reflexos, os maus olhares, as más palavras. Talvez a perdição da nossa alma. E temos que manter nossa alma livre" (Ibid.). Lúcia acenou espantada, não esperava esse tipo de postura em um ambiente que a tinha deixado tudo menos confortável e amparada.

Entretanto, a jovem mais humilde ficou irritada com o comportamento da garota loira, achando que o aconselhamento era deveras estranho, podendo ser somente um modo de ela fazer-se de interessante. Ainda assim, ela percebia que talvez tivesse sido um modo de a garota alertá-la de algum perigo, algo que não percebia. É interessante pensar na imagem dessa jovem desconhecida. De algum modo, ela surge com palavras misteriosas que despertam em Lúcia a inquietude, talvez por ela falar sobre algo que a humilde menina ainda não via ou não entendia. Porém, a garota de cor-de-rosa reconheceu na menina humilde a beleza, tanto a externa - quando falou de sua pele branca - quanto, de certa forma, a interna, ao opor os maus reflexos, isto é, os olhares de condenação, ao sentimento de humilhação da protagonista, comparando-os a algo maléfico que apreende a alma. Também reconhece que em tais olhares não há verdade, sugerindo que em Lúcia havia, o que cria uma oposição entre mal versus bem e verdade versus aparência.

Nesse sentido, podemos recuperar a fada madrinha do conto infantil original e estabelecer um paralelo com a jovem loira do vestido rosa. Na narrativa da Cinderela, a fada somente possibilita as mudanças necessárias à menina borralheira por reconhecer nela a bondade, a resiliência e a generosidade, e não a beleza externa. Ela mereceria estar no baile pela sua grandeza moral, não por ser somente mais uma jovem bonita do reino. Na reconstrução de Sophia Andresen, a jovem de cor-de-rosa alerta Lúcia, de certo modo, sobre a maleficência das aparências, pois as meninas que a julgavam e a menosprezavam estavam fazendo isso com base no traje lilás velho da protagonista, algo aparente e superficial. No fundo, Lúcia guardava uma beleza interna que a moça loira pôde 
reconhecer e tentou aconselhá-la exatamente sobre isto: as aparências não nos dizem a verdade. Elas querem tomar nossa alma, como sugere a personagem. Há, assim, por trás das palavras que soaram misteriosas para Lúcia, uma crítica da menina de rosa sobre o mundo das aparências, no qual as pessoas são julgadas de acordo com o que aparentam ser e ter. Diferentemente do conto de Perrault, temos um valor social sendo expresso que se refere ao caráter maledicente, de acordo com a garota, de indivíduos que classificam os seus semelhantes conforme os bens que possuem e os trajes que vestes. Essas palavras se constroem no texto como um presságio da viragem que vai ocorrer na vida da jovem humilde, o ponto de ação do conto.

Tal diálogo suscita uma reflexão acerca do ambiente em que Lúcia adentra, mas não é bem-vinda. Temos uma festa que ocorre em uma grande casa iluminada e movimentada, provavelmente pertencente a alguém da aristocracia ou da alta burguesia. A casa ostenta a posição social de seus donos e de seus convidados, que exprimem modos de agir e um estilo de vida coerentes com a camada social a que pertencem. Como observa o sociólogo Pierre Bourdieu, às diferentes posições no espaço social se relacionam diversos estilos de vida, ou seja, o conjunto de práticas, de hábitos e de posses que são a expressão das condições de existência de um determinado indivíduo ou grupo (1983, p. 73). De acordo com esse pensamento, as roupas que esses convidados vestem, os alimentos e bebidas que consomem e as músicas que ouvem refletem traços de identificação com os grupos privilegiados da sociedade. Do mesmo modo, o traje de Lúcia, revelador de sua origem humilde, coloca-a objetivamente na posição de não pertencente àquele grupo. Não temos indícios no conto que nos permita definir se a classe em questão é uma elite aristocrática ou alta burguesia, porém sabemos que é um setor extremamente privilegiado da sociedade, o que se opõe à situação da jovem garota de vestido reformado. Assim, da fala da personagem loira podemos depreender a ideia de que o grupo social que frequenta a festa pauta-se nas aparências, ou seja, na observação do modo, dos trajes e dos hábitos daqueles que o cercam, o que seria, de acordo com ela, negativo, que causa mal.

Lúcia, deslocada, mantém-se afastada do baile, olhando de canto as luzes, o movimento e os jardim da bela casa rosa. Sua posição é simbólica, pois ela, de fato, está à margem daquele grupo, daquele "mundo de divertimento". O passaporte para tal classe seria sua aparência. Ela, apesar de bonita, não tem os trajes necessários para ser aceita e bem vista. Não importa sua pele ser bonita ou ela ser uma pessoa bondosa, com uma história de vida difícil. O que realmente a faria ser parte daquilo é o que ela aparenta ser, 
e seu velho vestido fora de moda é indicativo de que ela não tem nem o mínimo para pertencer a essa camada. Suas roupas falam por si. E seu sapato roto e largo denunciam seu deslocamento, sua postura "intrusa".

Nesse aspecto, o conto aponta para uma crítica que já tínhamos observado em Pequenos Burgueses, de Carlos de Oliveira. O modo como a elite se comunica e se configura mantém as aparências em relevo. O que parece importante é aquilo que se consegue mostrar, aquilo que é de modo aparente, e não o que é realmente, a sua verdade. Os olhares, assim, determinam o que é aceito ou não, o que é superior ou não. Mas os olhares não veem necessariamente o real. O livro indica o véu que cobre a realidade, e o conto nos indica justamente esse véu através das palavras da garota loira. Há em ambas as narrativas uma abordagem sobre como a classe favorecida, seja a autocracia, seja a elite rural, organiza-se em torno daquilo que se pode aparentar, uma riqueza expressa de forma concreta e objetiva em elementos materiais. Haveria, portanto, uma valorização de possuir, de ter, de aparentar em detrimento do ser, da essência, do real.

É interessante observar que o termo "aparência" tem, para a filosofia, dois significados bem distintos. Por um lado, ele traz a ideia de "ocultação da realidade". Por outro, ele seria a "manifestação ou revelação da realidade"112. De acordo com o primeiro sentido, a "aparência" obscurece ou vela a realidade das coisas, "de tal modo que esta só pode ser conhecida quando se transpõe a aparência e se prescinde dela" "113. É justamente nessa acepção que tanto Carlos de Oliveira como Sophia Andresen veiculam a ideia superficial de existência que ordenaria as classes abastadas da sociedade. Aparentar ser rico é, na cabeça de Marciano, como vimos, um passaporte para a entrada do mundo dos jogos no Café Atlântico, por isso o cargo de gerente dos armazéns lhe cairia bem. Ser gerente traz a aparência de se ter um cargo importante, logo uma posição privilegiada. $\mathrm{O}$ Dono da Casa, em "O Jantar do Bispo", cultivava sua suposta benevolência para manter o poder em seu território. Sua caridade era assim uma aparência, um véu sobre seu caráter real. Diante de Lúcia, no conto em questão, a garota de chiffon rosa reflete justamente sobre a ocultação da beleza real que os adornos e os vestidos da moda poderiam trazer para a menina humilde.

Nesse sentido, "no primeiro caso, a relação entre aparência e verdade é de contradição e oposição"114 e as classes no poder, na visão de ambos os autores, articulam

\footnotetext{
${ }^{112}$ Cf. verbete "aparência" in: ABBAGNANO, Nicola. Dicionário de Filosofia. p. 68.

113 Ibidem, p. 68.

114 Ibidem.
} 
suas relações por meio daquilo que a realidade aparenta ser, não o que é de fato. Em "A História da Gata Borralheira", temos tal abordagem através de alguns aspectos. Primeiramente, Lúcia vê o mundo das pessoas ricas com aquela aura feérica, iluminada e cheia de divertimentos, isto é, aquilo que esse ambiente aparenta ser. Em segundo plano, temos as garotas do baile, que colocam Lúcia em seu lugar - marginalizada no espaço da festa - justamente por sua aparência física, o que o seu vestido diz: estar vestida com um traje fora de moda significa que a pessoa não tem meios de ter uma roupa da tendência atual. Ora, se ela precisa utilizar um vestido velho ou emprestado, o lugar dessa pessoa não é naquele mundo privilegiado do baile. Não importa que houvesse beleza física em Lúcia. Seu lugar é determinado pelos seus trajes. Não importa o que ela tem a dizer, assim como ocorreu ao mendigo misterioso de "O Jantar do Bispo", que fora julgado pela criada Gertrudes por suas vestes sujas como sendo "mais um pobre". Não lhe deu ouvidos quando ele pediu a palavra. Nesse pensamento, os propósitos de um indivíduo ou o seu caráter não são maiores do que aquilo que se aparenta ser.

Houve, porém, alguém que viu Lúcia além dessa aparência que oculta a realidade. Vimos a menina de vestido rosa, mas também há o jovem que inicia uma conversa singela com a garota humilde, enquanto ela achava também que ele estaria rindo dela. $\mathrm{O}$ rapaz fala, então, sobre o ambiente externo que parece mágico: o luar entre as sombras das árvores, o reflexo da luz no lago. De forma sutil, Sophia cria nesse momento uma oposição. Lúcia estava espantada com o ambiente belo da festa, as luzes, o movimento dos vestidos na sala de baile. O rapaz, por sua vez, admira-se com o mundo natural do jardim. Ele, então, faz uma reflexão que parece estranha à protagonista.

\footnotetext{
- Estas noites assim não a assustam?

- Assustar? Porquê?

- Tanto azul, tantos brilhos, brisas, perfumes parecem a promessa de uma vida deslumbrada, que é a nossa verdadeira vida. Mas, ao mesmo tempo, há nestas noites uma angústia especial: há no ar o pressentimento de que nos vamos despistar, nos vamos distrair, nos vamos enganar e não vamos nunca ser capazes de reconhecer e agarrar essa vida que é a nossa verdadeira vida (ANDRESEN, 2017, p. 18).
}

Lúcia duvidou do seu entendimento acerca desse diálogo. Ele surge ao leitor como o ponto de início da viragem da protagonista. O rapaz fala da beleza e da presença da noite como nossa verdadeira vida. Enquanto isso, Lúcia admirava o lugar das aparências, o mundo dos vestidos belos. É como se o menino a alertasse de que aquilo não era uma vida de verdade. Os brilhos que a menina via traduziam o poder aquisitivo daqueles 
convidados e a necessidade de se manter a expressão da riqueza e da posse, o que não seria, para o rapaz, a "verdadeira vida", afinal são marcas de distinção de classe, são artifícios para demarcar uma posição social. Para ele, os brilhos enganam, confundem. Mas o anseio de Lúcia em adentrar essa realidade foi muito maior e "compreendeu que não poderia dizer que para ela a verdadeira vida seria estar naquele baile com um vestido lindíssimo. Essas coisas não se dizem" (ANDRESEN, 2017, p. 24).

O rapaz, então, tira-a para dançar. Ela hesita, pois diz não saber fazê-lo e acha melhor parar. Ele a elogia, diz que gosta de dançar com ela, mesmo que não o saiba. $O$ rosto da jovem se ilumina diante de tal elogio. Havia um belo rapaz a cortejá-la, ele colocava nela a atenção "de alguém que pertencia ao mundo de brilho e poder, onde ela queria penetrar". Aproximam-se aqui a imagem desse moço com a do príncipe de Cinderela, mas este se encanta pela beleza exterior da donzela, enquanto aquele se atrai pela Lúcia "real", e não por aquilo que ela aparentava ser, vestida com os trajes velhos. A agonia dela, de ser o motivo de riso daquela sociedade, parecia naquele momento extinguir-se.

Ocorre, no entanto, a situação da qual Lúcia mais tinha medo: nos movimentos da dança, o sapato roto saiu do seu pé e ficou à mostra na sala de baile, estando ainda mais feio que antes, pois, com o uso, a seda soltou-se na biqueira e no salto. Todos olhavam e comentavam quem teria usado aquele calçado tão miserável. Todos se afastaram do local e um criado, a mando da dona da casa, foi retirar o objeto com uma pinça. Lúcia estava mortificada e não ousava olhar para o rapaz, afinal não sabia se ele teria percebido que o sapato era, na realidade, dela. Este se torna, então, o ponto de mudança na narrativa. Quando ele se afasta para buscar algo para beberem, ela foge desesperada do local.

Em sua tentativa de esconder-se, ela entra por uma pequena porta que lhe dá acesso a uma salinha repleta de espelhos, o que aumenta mais ainda seu sentimento de humilhação, conforme analisam Coelho e Azinheira (1995, p. 13). Os objetos refletiam a vergonha que ela sentia, a pequenez de sua situação diante daquela sociedade que olhou enojada para o calçado roto. Vai à varanda, observa que o seu par parecia procurar-lhe e, no clima de humilhação, já pressupõe que o teriam avisado que ela fora à procura do seu sapato perdido. Vexada, ela se escondeu em um canto sombrio, onde havia um banco. Começa a se imaginar naquele mesmo baile, vestida com belo traje e um lindo sapato. Não sendo motivo de escárnio de ninguém. Como poderia mudar sua vida?

Ela, então, sentindo-se humilhada e inferiorizada decide aceitar a oferta da tia/madrinha que, na ocasião dos seus 18 anos, disse-lhe: 
Lúcia, tens dezoito anos, é preciso pensar no teu futuro. Não conheces ninguém, não és convidada para nada, andas vestida como uma pobre. Vem viver comigo, que sou tua madrinha e não tenho filhos. Se vieres viver comigo, eu dou-te todas as coisas de que precisas (ANDRESEN, 2017, p. 24).

No momento, a menina não aceitou a oferta, pois pensava no pai e nos irmãos. Porém, naquela situação, diante de tanta vergonha, repensava suas escolhas. Podemos pensar em uma analogia entre a tia e a fada-madrinha. No conto de fadas, a criatura mágica resolve intervir dada a bondade e a generosidade de Cinderela. Na releitura andreseniana, observamos que a tia intervém na vida de Lúcia, pois ela se encontra em uma família arruinada, que não lhe dará nenhum futuro. Vivendo somente sua vida humilde, a menina certamente não teria chances, por exemplo, de ter um bom casamento, com um marido abastado que lhe oferecesse conforto e riqueza. Temos ainda na fala da tia a referência às vestes de Lúcia: “andas vestida como uma pobre”. Novamente, é um elemento ligado à noção das aparências dentro da sociedade.

A partir dessa fala, podemos extrair dois mecanismos de ascensão social que são importantes para a tia em relação à Lúcia: o casamento e a herança. Em uma sociedade aristocrática, ambos os fenômenos são interpretados como modos de se aceder a uma determinada classe social superior. A herança é um processo natural, a riqueza passa de geração a geração. Assim, a menina humilde poderia ter em vida todo o conforto promovido pela riqueza da tia, sendo uma espécie de herdeira. Ademais, estando bem vestida, frequentando bailes e eventos, Lúcia seria vista, sendo possível atrair um bom pretendente para se realizar um casamento vantajoso. Dessa forma, a menina deixaria de viver uma vida arruinada e poderia ascender socialmente.

Sentada no banco após o acontecimento do sapato, a menina reflete que não pode renunciar ao caminho oferecido, mas pondera que, ao aceitá-lo, abriria mão da liberdade que tinha, pois a tia tinha uma "minuciosa tirania" e "discursos de prudência e cálculo" (ANDRESEN, 2017, p. 25). Ela, então, recorda-se das palavras da garota de chiffon rosa: “Que era preciso não se importar". Mas Lúcia não podia ignorar o que sentia. O sentimento de humilhação, de vergonha, estavam a guiando: "Aquele baile, aquela gente que a ignorara e humilhara era o mundo que ela decidira escolher. Aqueles eram os vestidos, os sapatos, as joias que ela queria possuir. aquele, o poder que desejava” (Ibid.). Motivada por essas emoções, faz uma promessa a si mesma: “Tenho de escolher outro caminho. Um dia hei de voltar aqui com um vestido maravilhoso e com sapatos bordados 
de brilhantes" (Ibid.). Nesse retorno, ela seria "o alvo das atenções, da inveja, do espanto de toda a gente", como analisam Coelho e Azinheira (1995, p. 13).

A tia, assim, assume um papel da fada-madrinha ao possibilitar a Lúcia uma mudança de classe e o ingresso no mundo que tanto desejou, porém de forma perversa, pois é como se ela comprasse a menina. Para que pudesse receber as benesses, ela teria que viver com a madrinha, abandonando a vida modesta junto de seu pai. Há um caráter negativo na atitude da tia. O conto de fadas traz "imagens simbólicas fantásticas para a solução de problemas", conforme analisa Bettelheim (2002, p. 40), e, em A Gata Borralheira, temos uma temática recorrente: "uma criança sofrendo ciúmes e discriminação de seus irmãos [...]" (Ibid.). Na releitura do conto, Sophia Andresen busca trazer também uma certa noção de inveja ${ }^{115}$, lida no desejo de Lúcia de se tornar uma pessoa da classe rica, a segregação - a consequente marginalização da menina ao ser observada e julgada pelo grupo favorecido por causa de suas vestes humildes. Esses fatores levam-na a abrir mão de uma vida em que tinha liberdade para ascender a um grupo social que a rejeitara anteriormente.

A partir da resolução de Lúcia, entramos na segunda parte do conto. Foi viver com a tia e iniciou uma nova trajetória. "Onde antes encontrara desprezo, agora encontrava triunfo. Todas as coisas lhe eram oferecidas, como por mãos invisíveis. Era como se tivesse penetrado num palácio mágico, onde tudo a servia, tudo a obedecia" (ANDRESEN, 2017, p. 26). Ela adentrou a uma camada que tudo recebia, cujo poder determinava tudo: "A partir do dia da escolha, o seu êxito tornara-se mecânico. Ela nem precisava quase de lutar por ele, ele aparecia-lhe, tudo o suscitava. Era como se nela houvesse uma fatalidade do triunfo" (ANDRESEN, 2017, p. 26). Sophia ilustra, na mudança de vida da jovem humilde, o poder do capital refletido na classe aristocrática. Todos os caminhos surgem sem esforços para tal grupo, daí a "fatalidade do triunfo". Na vida de Lúcia, agora, tudo certamente daria certo e todas as portas estariam abertas. Casou-se com um homem rico, que, depois da união, enriqueceu mais ainda. Tornava-se mais bonita a cada dia que passava. "O mundo tem um preço, e Lúcia pagou o preço do mundo". Abriu mão daquilo que era "vivo e livre" para ter tudo o que sempre desejou.

\footnotetext{
115 O uso do termo "inveja" nesse trecho configura-se mais como "ter anseio pela condição do outro" do que "ciúmes ou desgosto sobre a situação de prosperidade do outro". Cf. verbete "inveja" no Dicionário Houaiss da Língua Portuguesa - Edição Eletrônica. Nesse caso, o uso do termo em francês, "envie", seria interessante, pois ele condensa em si a ideia de desejo e de inveja como ciúmes. No conto, não temos na personagem Lúcia a expressão de ciúmes, e sim um desejo de pertencimento a uma classe favorecida.
} 
É interessante notar que a crítica sobre a aristocracia presente em alguns contos de Sophia Andresen permite-nos uma leitura de um dado biográfico seu. A sua família é da aristocracia do Porto e tal fato leva muitos críticos a questionar o caráter social da sua obra. No entanto, como observa Clara Rocha, para a autora, "a fidelidade à origem nobre nada tem que ver com a vaidade de exibir em sociedade a sua condição socialmente superior, nem tão-pouco com o calculismo ou com a piedade caritativa em relação aos oprimidos" (1980, p. 12). Ao contrário de uma escrita isolada em uma posição favorecida, a obra andreseniana analisa de forma contundente a postura desse grupo social, destacando, por um lado, um caráter de falsidade e artificialidade nas aparências mantidas por esses indivíduos nas suas relações sociais e, por outro, a frieza e a indiferença com que agem diante dos menos favorecidos.

A poeta engendra uma diferenciação entre nobreza e aristocracia, estabelecendo uma concepção que liga a primeira a valores nobres, como a justiça, a busca pela harmonia e pelo equilíbrio, elementos propiciados pelo seu diálogo com a cultura helênica, e a noção de "exigência em relação aos outros" (ANDRESEN, 1986, p. 73) algo que associa à sua criação cristã. Tal perspectiva intensifica-se a partir de um posicionamento antisalazarista, opondo-se de modo crítico ao governo que mantinha grande parcela da sociedade relegada à miséria. O Estado Novo baseava-se em políticas de caráter antiliberal, apoiado em estruturas rurais, enquanto a industrialização surgia lentamente. A população seguia condicionada pela estagnação do desenvolvimento econômico, pela censura e pela polícia política, a PIDE, que controlavam a divulgação das informações e das opiniões, conforme analisa Luís Reis Torgal (2001, pp. 391-415).

Nesse contexto, Sophia Andresen elabora desde Contos Exemplares uma aguda crítica em torno do comportamento da camada privilegiada da sociedade portuguesa, como observamos em "O Jantar do Bispo" e também no conto "Retrato de Mónica", que liga esse grupo a um viés de hipocrisia diante das desigualdades socioeconômicas presentes no cenário português. A releitura da Gata Borralheira vai inserir Lúcia justamente nesse mundo quando ela opta em viver com sua tia e adentrar à realidade da classe dominante. Ela mantinha seu vestido lilás reformado, que fora motivo de escárnio em seu primeiro baile, guardado em uma caixa, como se guardasse sua própria origem. "Preciso queimar este vestido" (ANDRESEN, 2017, p 26), pensava a moça, em uma tentativa de apagar a vergonha e a humilhação que sentira por não ser parte daquela sociedade que tanto admirava. 
Vinte anos se passam e a protagonista recebe um convite de um baile a ocorrer na mesma data e na mesma casa onde fora humilhada quando jovem. Ela, então, lembra-se da promessa que fez para si mesma e pareceu-lhe que naquela ocasião deveria trazer todo seu triunfo como um modo de apagar da memória qualquer vestígio de vergonha que sentira, expressando um ressentimento acerca do passado e de sua origem. Para Lúcia, era necessário voltar à sala dos espelhos e ver neles refletido seu sucesso, sua beleza e sua riqueza. Na noite do esperado evento, arrumou-se, vestiu-se e perfumou-se, fitando a roupa antiga: "Amanhã vou queimar este vestido" (Ibid., p. 28). Essa peça relembra-lhe não somente a vergonha de ser motivo de risos, mas o fato de ser uma jovem humilde e pobre. Ao guardar o vestido dentro de uma caixa, dentro de uma gaveta, era como se abafasse o passado, suprimisse-o da sua vida de triunfos atual. Agora seria sua chance de vingar-se de todo o sentimento de diminuição ao qual foi exposta.

Assim como Cinderela, quando Lúcia chega à casa da festa, causa surpresa a todos os convidados:

Quando ela apareceu no limiar da grande sala de baile, primeiro, ninguém acreditou no que via. Agora os vestidos de baile já não se usavam compridos até o chão: a saia de Lúcia terminava um pouco acima das canelas. E os seus sapatos bordados de brilhantes viam-se bem. Algumas pessoas pararam de dançar. Lúcia deu lentamente a volta à sala, mostrando o brilho dos seus passos (ANDRESEN, 2017, pp. 2829).

Sua entrada causou murmúrios sobre a beleza e o brilho dos calçados. Alguns diziam que eram joias falsas que os ornamentavam. Mas o reflexo das pedras indicava que eram peças verdadeiras, causando "um primeiro movimento de espanto e quase escândalo" (Ibid., p. 29). Conforme dançava, o lume dos diamantes espalhava-se "em toda sua pessoa" (Ibid.).

O par de sapatos do presente contrastam agudamente com o do passado - onde existiam furos, agora há diamantes. Para Lúcia, não bastava ter obtido o triunfo de finalmente pertencer à classe dominante, era preciso ostentar sua posição, como um modo de suprimir toda a lembrança vexatória de sua juventude. Ao exibir seu luxo e sua beleza por meio dos sapatos - algo que se estendia para a sua figura -, ela causaria o espanto, e os murmúrios seriam agora de admiração, não mais de escárnio, como foram no passado. O pertencimento à classe tão admirada era exposto de forma avassaladora na sala de baile pelas joias no sapato, que representam ao mesmo tempo a vaidade da camada privilegiada e o orgulho de Lúcia de fazer parte dela. A personagem, assim, não apagou seu passado, 
mas tentou suprimi-lo pela ostentação. A opressão sentida no passado tornou-se a imposição do poder do presente.

Apesar do "quase escândalo" e do burburinho na sala de bailes, Lúcia precisava ver-se ainda na sala dos espelhos, cujos reflexos expuseram a sua humilhação vinte anos atrás. Entrou na sala e deparou-se com o mesmo espelho. Viu diante dele a mesma imagem do passado também. "Todo seu corpo gelou, num movimento de horror. O seu sangue parou de correr" (ANDRESEN, 2017, p. 30). Ela queria gritar, mas não conseguia, sentia o grito preso em sua garganta. "E o vestido parecia encher a sala, espalhar-se no ar. A sua cor parecia erguer-se como uma palavra, parecia escorrer como um metal fundido" (Ibid.). A comparação entre o lilás do vestido e a ideia de "palavra" indicam como a imagem presentificava-se através do espelho. A presença do passado tão suprimido crescia em frente ao presente luxuoso da mulher.

Essa cena nos remete, novamente, à concepção de humilhação e inferioridade que Lúcia sente e sentia de pertencer a uma classe humilde. Diferentemente de Cinderela, que aceitava sua condição com humildade e resignação - ainda que fosse, na realidade, filha de um fidalgo -, a protagonista andreseniana rejeita sua posição, mesmo reconhecendo a liberdade daquela vida, em contraste com o autoritarismo da tia. À situação inferior, ligam-se os sentimentos de vergonha, de negação. Ao âmbito superior, associam-se, por um lado, o desejo e a admiração e, por outro, o não pertencimento, que instiga o anseio de ser parte dessa camada. A jovem decidiu viver com a tia, mas foi uma decisão conflituosa desencadeada pela vergonha que sentiu no baile da juventude. Tais percepções se transformam na ostentação arrebatadora e opressora dos diamantes vinte anos depois, porém a sala dos espelhos reflete a verdade da personagem, como se sua origem genuína saísse pelos reflexos, como se sua alma módica fosse refletida ou ainda o seu ressentimento diante da humilhação do passado. Desse modo, a riqueza nela apresenta-se na superfície, no exterior, naquilo que os outros veem. O que ela enxerga, todavia, é a humildade de outrora, que desperta o mesmo sentimento vexatório.

Um dos espelhos da sala move-se e deixa entrar um homem "de bela aparência e de ar exato e brilhante” (Ibid., p. 31). Era o jovem par de Lúcia de antigamente. Ele diz que a observara desolada outrora, dizendo-lhe: “- Há vinte anos, aqui, nesta varanda, escolheste o outro caminho. Eu sou o outro caminho" (Ibid.). Essas palavras retomam a fala dessa personagem quando jovem sobre a noite trazer o pressentimento de que "nos vamos despistar [...], nos vamos enganar e não vamos nunca ser capazes de reconhecer e agarrar essa vida que é a nossa verdadeira vida" (ANDRESEN, 2017, p. 18). A escolha 
da menina humilde foi justamente o engano, o mundo das aparências, das luzes artificiais. Ela escolheu se importar com uma vida que não era a sua verdadeira, distanciando-se de sua origem e da sua liberdade. Nesse aspecto, entendemos as palavras de Seixo ao dizer que a releitura traz "uma história de alienação" (1985, p. 94), ou seja, a perda da vida natural, a privação de sua proveniência, de sua essência em favorecimento de sua aparência e de seu poder.

O belo homem pede a ela, então, o sapato do pé esquerdo. Lúcia responde-lhe com raiva que não o daria, afinal ela o conquistou, sendo o trabalho de toda sua vida. $\mathrm{O}$ assertivo indivíduo estava lá para cobrar o preço da escolha dela: "Lembra-te: a partir daquela noite de há vinte anos tiveste uma vida maravilhosa. Nada te foi recusado, nunca mais sofreste uma humilhação. Outros sofreram, foram abandonados, humilhados, vencidos. Tu não. Tu venceste sempre. Dá-me o sapato: é o preço do mundo (ANDRESEN, 2017, p. 32). O sapato seria como uma compensação de toda a subjugação e rejeição sofridas por aqueles que não escolheram o caminho de Lúcia, conforme analisam Coelho e Azinheira (1995, p. 14). Desse modo, o poder ostensivo do calçado expressa o poder da classe escolhida pela menina. Enquanto a camada favorecida vence e tem todas as portas abertas, os desfavorecidos são explorados, são vencidos. Por isso, ele lhe pedia o símbolo dessa conquista - uma vitória à custa de muitos outros que não puderam escolher tal caminho.

Lúcia preocupava-se em perder o poderoso sapato e ficar com um pé descalço, mas o homem lhe oferecia o pé daquele antigo calçado "velho, miserável, esfarrapado" azul (Ibid.). Então, ele inclinou-se, tirou-lhe o salto de brilhantes e colocou-lhe o velho objeto. A protagonista não conseguia fugir daquele local, não podia se mover. Foi encontrada morta no dia seguinte, uma síncope cardíaca. Mas o que todos comentavam era por que ela estaria com um pé de calçado velho e roto; não havia explicação para aquilo. O fato fora comentado "com paixão obcecada" por um tempo, mas depois foi esquecido, diferentemente da história da Gata Borralheira que há séculos é comentada, recontada e recriada.

O conto nos coloca diante de uma dicotomia constante: a Lúcia de antes, empobrecida e envergonhada, e a Lúcia após a sua escolha, enriquecida, bela e vitoriosa. Podemos ler, novamente, a polarização entre as camadas sociais: de um lado, há o grupo representado pelos aspectos da pobreza e, do outro, a camada dominante, que vive em festas, em uma grande e iluminada casa cor-de-rosa, com vestidos belos que flutuam pelo ar. Pelo menos é essa a visão da protagonista sobre esses mundos. O seu desejo de 
ascensão social reflete a desigualdade entre os dois polos. Um é vivenciado pela humilhação, outro pela admiração e anseio de pertencimento. Um é experienciado pela falta de condições, pela feiura da humildade; outro, pelo triunfo constante, pelo brilho e pela beleza.

Temporal e espacialmente, observamos tal dualidade por meio da trajetória da protagonista, construindo uma tensão entre a concepção de classe dominante e dominada aos olhos da autora. Há um mundo de antes, visto como "natural", conforme observam Coelho e Azinheira (1995, p. 27), e o mundo após a escolha, compreendido como o espaço de poder. Lúcia transita entre os dois campos ao longo de toda a narrativa, como se, mesmo sendo rica e poderosa, a sua origem humilde não pudesse ser suprimida. "Os dois mundos descritos surgem consubstanciados em dois tipos diversos de espaços: o espaço da natureza, puro, essencial, espontâneo e o espaço da casa onde se ressalta o brilho artificial, ilusório [...]" (Ibid.). O que une os dois mundos é a escolha tomada por Lúcia e o preço a se pagar por ela. É a perda da liberdade e de tudo "que era quente, vivo" (ANDRESEN, 2017, p. 25) para se sujeitar à autoridade da madrinha em troca do ingresso ao mundo que ela sempre desejou.

Sophia Andresen cria, através do diálogo constante com a ideia de moral suscitada pelo conto infantil, uma dicotomia entre bem e mal, assim como verificamos anteriormente em "O Jantar do Bispo". Essa tensão retoma a relação com os contos de fada, que

transitam, quase sempre, pelo universo maniqueísta e o herói ainda que torturado, sacrificado, maltratado e silenciado resiste até o fim da narrativa, quase o fim de sua vida, para emergir de sua ausência forçada e concretizar todos os sonhos possíveis e impossíveis numa pequenina fração de segundos - pequenina porque é aí que a narrativa termina (POMA, 2008, p. 219).

Em "A História da Gata Borralheira" esse conflito é resgatado. O lado de "antes da escolha" da jovem reflete uma beleza natural, livre e original, que fez Lúcia ser vista no baile pela misteriosa menina de chiffon cor-de-rosa e pelo jovem rapaz. Mesmo em trajes simples, ela despertou a atenção de seu par e da outra garota, que ainda a aconselhou a não se olhar nos espelhos, pois eles não diziam a verdade, assim como as pessoas más. Ora, temos pela fala da garota de vestido rosa a segunda parte da dualidade: o mal, condensado no tempo “após a escolha" e ligado ao aspecto da vida artificial, da ostentação e da mentira. 
Seguindo a lógica do conto, o lado anterior e genuíno de Lúcia é visto pelo caráter do bem, sendo relacionado à sua proveniência humilde, com seu pai arruinado financeiramente e seus irmão malcriados e relegados pelas criadas. Do mesmo modo, observamos o mendigo misterioso do conto anterior e o padre de Varzim, ambos em suas vestes esfarrapadas e sujas de lama. No vestido reformado da protagonista e nas paredes de sua antiga casa, cujo "papel se descolava da parede" (ANDRESEN, 2017, p. 25) está a pobreza, mas também um espaço natural e livre, por isso vivo. A beleza anterior de Lúcia é vista pela garota de vestido rosa - apesar de suas vestes simples e fora de moda -, pois essa personagem enxerga, de certo modo, ambos os mundos com uma clarividência que faltava à protagonista, iludida pelas luzes artificiais da grande casa em festa. Haveria, assim, a beleza da virtude dessa vida empobrecida da jovem, captada pelas outras duas personagens.

Não obstante, o mundo original, empobrecido e natural ao qual Lúcia pertencia é associado, pela subjetividade dela, aos sentimentos de humilhação e de inferioridade. A simplicidade de seu vestido é, para a maioria das garotas do baile, motivo de escárnio. A situação vexatória vivenciada quando o sapato roto solta-se do seu pé mostra que o outro mundo, aquele por que a protagonista anseia, é o campo das aparências e da vaidade, vinculados às ideias de superficialidade e de mentira. Lúcia, minimizada pela vergonha, não quer ser humilde e pobre, pois estes são inferiorizados, desprezados. Por isso, seu desejo e admiração pela classe superior mostra um conflito da personagem. Ela anseia viver em um grupo que não seja humilhado, mas tal camada é vinculada a aspectos negativos. Compreendemos isso, por exemplo, a partir da fala da personagem de cor-derosa, que relaciona certos espelhos às pessoas más. O espelho em que Lúcia se vê reflete sua exterioridade, aquilo que pode ser visto superficialmente, mostrado pela a pobreza de suas vestes. É a mesma visão da maioria dos convidados - pertencentes à camada dominante da sociedade. Assim, associa-se a esse grupo um olhar de artificialidade, a vaidade e a importância da aparência externa. A dualidade bem versus mal estende-se, desse modo, em uma polarização entre o grupo socioeconomicamente privilegiado e o desfavorecido.

Tal conflito intensifica-se com o desejo de ascensão social de Lúcia, que, desde o início do conto, mostra-se atraída pelo deslumbrante mundo da grande casa. O tempo do baile é a noite, simbolicamente lido como período de "obscurecimento, obnubilação", como observa Aleixo (1985, p. 94). O estado de perturbação de consciência da protagonista deve-se ao sedutor ritmo do baile e à atraente euforia da grande e iluminada 
residência, que iludem a garota e a convidam para adentrar um mundo ao qual não pertence. Ainda assim, Lúcia entra no local, é vista no baile e desperta o menosprezo das outras garotas, expondo seu não pertencimento àquele cenário. É, então, instigado na menina seu anseio, mas agora não pela sedução, e sim pela humilhação à qual ela foi exposta. Ela quer ser parte de um mundo onde não seja inferiorizada, onde possa ser vista pela beleza de suas vestimentas, onde ela possa ser apreciada como aprecia as outras meninas.

Nesse contexto, podemos estabelecer uma comparação entre a Cinderela e a gata borralheira andreseniana contemplando a questão da dualidade. No conto infantil, a jovem é animalizada, vista como um bicho doméstico e domesticável, conforme analisa Poma (2008, p. 220). Seu "outro eu”, que ocorre a partir da mágica da fada madrinha sobre elementos do mundo da natureza, a abóbora e os ratos, por exemplo, será a belíssima princesa desconhecia que deixa todos no baile espantados. "Num certo sentido, a menina retorna à sua origem, é humanizada e ultrapassa a condição inicial da bondade e da doçura misturadas, agora, a uma beleza única" (Ibid.).

Lúcia, por sua vez, também se modifica. É inicialmente ligada a uma noção de beleza natural - algo que é visto pelo seu par e pela garota de chiffon rosa a despeito de seu traje empobrecido. Sua vida é "quente, viva e livre" (ANDRESEN, 2017, p. 25), mas, ao fazer a escolha, ela se transforma. Seus triunfos fazem a sua beleza crescer a cada dia, mas externamente, como se ela estivesse se reificando - ainda que em crise com seu passado. O seu sapato concretiza essa beleza artificial e superficial, pois o seu brilho emana para toda a personagem. Em Cinderela, há um movimento da animalização, dado pela condição subjugante, para a humanização, quando ela pode, finalmente, ser a menina bela sem a opressão da madrasta, assumindo seu lugar de nobre. Em Lúcia, há um movimento da naturalidade ao artificial, ao reificado, o que é catalisado pelo seu anseio de mobilidade social.

Vimos tal desejo de ascensão na personagem de Marciano de Pequenos Burgueses, o qual era constantemente humilhado pelo Delegado por causa da sua origem social, que o colocou na carreira de "marçano". Também inferiorizado, a personagem alimenta anseios de mobilidade socioeconômica, podendo, um dia, sentar-se na cadeira de couro verde do Café Atlântico. Ele é também seduzido pela posição de poder, o que é amplificado pelo efeito da humilhação. Lúcia, por sua vez, também é cativada por um contexto que a exclui cruelmente. Esse se torna o motor de sua mudança. Por um lado, ela também quer desfrutar da beleza dos vestidos flutuantes na noite de baile. Por outro, 
ela não quer ser humilhada. Ambos os sentimentos movem as personagens, a menina escolhe um caminho longe da liberdade natural; o homem abre mão de qualquer valor positivo que teria ao tentar matar seu chefe. A cadeira de couro verde e o sapato cravejado de brilhantes concretizam esse conflituoso anseio de adentrar a um grupo social a que não se pertence, mobilizado, em ambos os casos, pela humilhação causada por parte de indivíduos que estão na posição socioeconomicamente superior. Os objetos condensam o forte sentimento de exclusão vivenciados por Marciano e Lúcia. Adquiri-los e exibi-los é uma tentativa de suprimir uma origem que lhes causa a vergonha. A ascensão social não é um simples desejo, mas um conflituoso sentimento de inferiorização.

Porém, tanto para Carlos de Oliveira como para Sophia Andresen, a ideia de ascensão é vista por um viés negativo, trazendo a contrastante ideia de um indivíduo que, humilhado pela camada superior, deseja juntar-se a ela. Nesse aspecto, observamos o poder da influência moral e intelectual do grupo dominante sobre indivíduos desfavorecidos, ilustrando o conceito de hegemonia gramsciniano citado anteriormente. No anseio de ser parte do outro grupo, é comum que a camada dominada adote a concepção de mundo dos dominantes, o que é uma forma de manter o poder destes sobre aquela. Em oposição, surgem personagens que desejam romper essa ordem, ou a "geringonça social", como o mendigo, de "O Jantar do Bispo", e o Dr. Seabra, em Casa na Duna.

Nessa perspectiva, podemos pensar na transformação do caráter de Lúcia. Ela, que suscita a imagem da Gata Borralheira dos contos de fadas dado o diálogo entre os textos, comporta-se, na realidade, após a sua escolha, como a Madrasta e suas filhas, para as quais "o mundo da realeza é garantia de beleza, riqueza e felicidade", como verifica Poma (2008, p. 221). Ela reflete sobre as palavras da garota de vestido rosa sobre não se importar com o reflexo dos espelhos - a metáfora da opinião das “más pessoas". Mas ela se importa, quer se importar. O poder é para essa personagem um desejo; adentrar aquele mundo é-lhe fundamental, sobretudo depois da situação inferiorizante por que passa. Na noite em que finalmente poderia vingar-se da humilhação sofrida, a personagem é comparada pela narradora a outra personagem do âmbito maligno:

Era preciso que ela, como a madrasta da Branca Flor, pudesse naquela noite perguntar a todos os espelhos da casa: - Dizei-me, espelhos, qual é a mais bela, a mais perfeita, a mais rica de triunfo, aquela que está em seu reino mais segura? E era preciso que todos os espelhos, até de madrugada, the respondessem: - Tu. (ANDRESEN, 2017, p. 27) 
Assim, vincula-se ao desejo de Lúcia de possuir e ser reconhecida e admirada, como outrora admirou as garotas, um viés negativo, aproximando-a às características maléficas das madrastas de contos infantis e fortalecendo a dicotomia bem versus mal do conto.

A relação da protagonista com o espelho é fundamental para que possamos compreender a tensão vivida: por um lado, seu desejo de ascensão social; por outro, sua vida humilde. Para Coelho e Azinheira (1995, p. 26), “essa relação determina todos os momentos e representa as duas opções, os dois mundos" vividos por Lúcia. Poma, por sua vez, observa que esse objeto retoma "o jogo entre essência e aparência, tematizado pelo escritor francês [Perrault], e radicalizado aqui" (2008, p. 226). Assim, haveria uma duplicidade no reflexo: a verdade daquilo que se vê em oposição a "uma contaminação de imagens entre o espelho que contempla e o objeto contemplado, assim como uma sobreposição da alma no corpo, do passado no presente" (POMA, 2008, p. 226).

Além disso, podemos pensar sobre a ideia de objetificação da imagem de Lúcia após sua ascensão. No primeiro baile, o que ela via nos espelhos era a verdade, era sua imagem genuína em vestes ultrapassadas e sapatos envelhecidos. Via ainda a humilhação que sentia, pois enxergava sua real origem, sua verdadeira classe social. No segundo baile, a protagonista espera justamente enxergar-se embelezada e enriquecida, como uma vingança à figura da adolescência. Os espelhos dir-lhe-iam que ela é a mais bela e a de maior triunfo. Ora, essa é a imagem artificial de Lúcia, pois ela deixou o mundo natural e adentrou o mundo superficial, das aparências. O que ela espera ver pode ser lida como uma imagem reificada de si, do que ela se transformou, concretizada nos adornos e, claro, no estonteante e poderoso sapato. Porém, os espelhos da sala continuaram refletindo a imagem real, daquela origem humilde, o que ela mais temia. O objeto não expressou a ascensão de Lúcia e, do mesmo modo como Cinderela correu contra o tempo, ela correu contra o seu passado, a sua proveniência humilhante.

Nesse sentido, podemos pensar que a temática do conflito de classes encarnada por Lúcia liga-se de modo estrutural a aspectos que são recorrentes na obra andreseniana, como a busca pela harmonia e pela justiça, além da valorização de um equilíbrio e unidade na relação do homem com o mundo. A tensão da personagem reflete um mundo marcado pela polarização entre as classes, em um desequilíbrio causado pelo poder que traz como consequências a subjugação, a exploração e a humilhação do grupo desfavorecido. Vemos também a relação que Sophia Andresen estabelece entre a vida "quente, viva, livre" e o mundo natural, associado no conto à vida simples da protagonista. O equilíbrio buscado entre o homem e sua realidade aparecem em oposição à presença da aristocracia 
admirada por Lúcia, pois esse grupo se expressa através de valores superficiais e artificiais, que corrompem a harmonia procurada pela autora.

Os valores socioeconômicos expressos nos contos andresenianos não perpassam somente o plano da temática, mas sofrem uma interiorização, como explica Antonio Candido (2014, p. 23), no plano estético das obras, isto é, associam-se aos valores fundamentais trabalhados pela autora no desenvolvimento do seu itinerário literário. Assumindo a busca pela justiça, a harmonia e a relação com o real, sua prosa demonstrase eficaz em expressar o caráter desigual e exploratório da sociedade de classes, indicando o egoísmo, o individualismo e artificialidade da camada favorecida em detrimento da vida dos mais pobres conforme a mundividência da autora. Se, para ela, a poesia é uma moral, pois suscita uma relação justa entre o homem e seu mundo, seus contos apontam para esse elemento por meio da denúncia da injustiça e do desequilíbrio, mostrando uma fissura da realidade, controlada pelo desejo de poder que gera consequências contra aqueles que são silenciados e humilhados.

Assim, "[...] temos o efeito de uma determinada visão da sociedade atuando como fator estético [...]" (CANDIDO, 2014, p. 23) na sua prosa. O seu diálogo com valores clássicos e o humanismo despertado pela sua formação cristã fazem dos fatores sociais presentes em seus contos não somente um conteúdo de denúncia, mas, sim, formadores da estrutura desses textos. Como afirma Candido (Ibid., p. 22), são elementos que formam a "integridade estética" da obra de Sophia, uma vez que, para ela, a poesia - e a sua literatura em si - implica e está implicada no real. A sua procura por uma relação justa entre o homem, os deuses e mundo passa, portanto, pela necessidade de expor a desigualdade e a exploração presentes na sociedade de classes.

Em ambos os contos analisados, observamos a questão da relação entre as classes e as suas consequências não somente como um aspecto do conteúdo, mas sim um elemento amplo e complexo que os mobiliza e motiva como obra literária. É uma temática que se coaduna à mundividência da autora, não se encontrando isolada no seu projeto literário. Tampouco pode ser vista somente como um fator condicionado pelo contexto sócio-histórico da autora, pois a sua concepção de escrita - por extensão da sua perspectiva sobre poesia - abrange a busca por uma relação justa entre o homem e a sua realidade, o que pressupõe a relação justa com os seus semelhantes. Desse modo, o viés social trazido por Sophia Andresen dialoga a todo momento com o projeto poético defendido pela autora, seja pela busca de harmonia e justiça, seja pela denúncia da privação e da desigualdade social imputadas ao homem pelo próprio homem. 


\subsection{A imagem real $X$ a imagem social: um retrato da riqueza e da pobreza em "O Retrato de Mónica" e "O Homem"}

No projeto poético de Sophia Andresen, frequentemente nos deparamos com a busca da conexão entre o humano, o mundo e os deuses. Essas imagens surgem, muitas vezes, ligadas a expressões como "o dia inicial", "o tempo inicial", como se o homem estivesse em um estágio mais próximo da natureza e da totalidade do mundo lidas pela autora através de sua interpretação da cultura clássica. O adjetivo "natural" em si carrega diversas acepções, mas podemos ressaltar algumas em particular que se relacionam a essa poética e à sua procura pela religação do homem aos elementos do mundo. "Natural” é a qualidade daquilo "que pertence ou se refere à natureza" ou "que é produzido pela natureza"116. Liga-se também à ideia de algo "em que não ocorre trabalho nem intervenção humana" e "que decorre normalmente da ordem regular das coisas"117. A partir desses conceitos, o homem por vezes perseguido na obra de Sophia parece estar em um momento anterior e inicial, que se contrapõe, como indica Belchior, ao momento do "tempo dividido", o tempo de "ameaça, tempo do ódio, tempo do nojo" (1986, pg. 34).

A partir da ampla significação do adjetivo "natural", podemos encontrar tanto na prosa como na poesia da autora a imagem do homem que vive (ou se encontra na busca) na inteireza do "tempo absoluto", como cita Belchior (Ibid.), e cuja vida está implicada "no rio ou na praia", isto é, seu ser implica-se no real, como diz a autora em seu ensaio "Poesia e Revolução" (ANDRESEN, 1977, p. 77), sendo a poesia essa mesma implicação. Nesse contexto, são criados diferentes retratos de homens e mulheres que se confundem com o mar e com a terra. Homens cuja barba branca é "igual a uma onda de espuma" (Idem, 2010, p. 129) ou cujas linhas do rosto são como as linhas da terra seca.

A simplicidade, por exemplo, aparece como um traço determinante da pessoa descrita no poema "Retrato de Mulher": "Algo de cereal e de campestre / Algo de simples em sua claridade / Algo sorri em sua austeridade" (2011, p. 629). Nos versos, a mulher apresentada traz noções que remetem àquilo que é natural pelo caráter "campestre", o que encontra ênfase no adjetivo "simples" presente em sua claridade. Em sua significação, a simplicidade pode associar-se àquilo que não é complexo; ao mesmo tempo, refere-se a algo ou alguém que demonstra "comportamento natural e espontâneo" 118 . Ao lermos a obra andreseniana, percebemos que tal simplicidade relaciona-se à noção das coisas que

\footnotetext{
116 Verbete "natural" in: Dicionário Eletrônico Houaiss.

117 Ibidem.

118 Verbete "simplicidade" in: Dicionário Eletrônico Houaiss.
} 
são vistas em sua realidade, na sua existência em si mesma. No percurso da autora, a busca pela apreensão do real passa pela concepção do poeta - e do homem - cuja existência está implicada nos elementos do mundo, como sugere em seu ensaio "Poesia e Revolução" (ANDRESEN, 1977, p. 77). Esse envolvimento pressupõe uma relação verdadeira "do homem com a árvore, com o rio" (Ibid.) e também com os seus semelhantes. Essa ligação suscita conceitos como a lisura, a clareza, como a da mulher cantada no poema, mas igualmente o simples, adjetivo cuja etimologia latina se vincula tanto à concepção de "algo singelo" como também de "algo único"119.

A simplicidade é cantada de formas distintas por Sophia Andresen e é explorada de forma particular nos Contos Exemplares, um livro que recupera, como já pudemos observar, o conflito entre classes sociais e a oposição dos valores que definem a pobreza e a riqueza. Vimos, em "O Jantar do Bispo", imagens da ostentação, vinculada normalmente ao caráter da classe economicamente favorecida, enquanto a pobreza ligase à imagem do mendigo, embalado pela simplicidade, pela humildade, mas também pela sua alusão a Cristo. Nos outros contos do livro, novos retratos são tecidos por meio de imagens que formam um embate entre os diferentes grupos sociais, seja pela simplicidade, humildade e claridade, seja por elementos contrastantes, como a falsa aparência e a opulência. É pelo viés da oposição entre as imagens da riqueza e da pobreza que propomos a análise dos contos "Retrato de Mónica" e "O Homem", que põem à luz não somente imagens importantes à poética de Sophia Andresen mas também o posicionamento político da autora diante da sociedade portuguesa do período salazarista e "uma profunda visão da vida", como indica Jacinto Prado Coelho (1970, p. 78).

Os adjetivos "simples" e "natural" encontram-se, nessa poética, ligados aos valores do grego de "harmonia" e "equilíbrio", que, por sua vez, relacionam-se à ideia de justiça nos Contos Exemplares, como observa Clara Rocha (1980, p. 10). De um modo bem peculiar, Sophia Andresen vai explorar esses conceitos por meio de valores opostos em "O Retrato de Mónica", cuja personagem principal é uma mulher da alta sociedade que condensa em si a eficiência, o luxo e a sociabilidade esperadas de uma pessoa pertencente às classes dominantes. A particularidade na descrição de tal retrato mostra-se no uso da sátira e da ironia, algo que não é comum na prosa andreseniana, manifestando "dissonância em relação aos outros contos e à restante obra da autora" (Rocha, 2001, p. 73).

\footnotetext{
${ }^{119}$ Verbete simplex in: FARIA, Ernesto (org.). Dicionário Escolar Latino-Português. Brasília: Ministério da Educação e da Cultura, 1962, p. 923.
} 
Diante deste conto particular, podemos fazer uma reflexão sobre seu título. "O Retrato de Mónica" indica, de forma clara, que seu conteúdo se relaciona com o retrato, o qual consiste em um modo de reprodução - seja pela fotografia, seja pela pintura - da imagem de uma pessoa (real ou imaginária). É, assim, um modo de reprodução de uma realidade pelo olhar de um outro. Para Susan Sontag (2004, p.70), “as fotos retratam realidades que já existem, embora só a câmera possa desvelá-las. E retratam um temperamento individual, que se descobre por meio da colheita da realidade feita pela câmera". Nossa "câmera" é a narradora irônica e detalhista que desvenda uma imagem da dita "perfeição" de Mónica. "Dita perfeição", pois o que se esboça no conto é, na verdade, um olhar crítico da narradora diante de tal mulher.

Sontag cita, em seus ensaios, a visão de dois importantes fotógrafos acerca do retrato. Para Moholy-Nagy ${ }^{120}$, "o gênio da fotografia reside na capacidade de transmitir 'um retrato objetivo: o indivíduo a ser fotografado, de sorte que o resultado fotográfico não seja embaraçado pela intenção subjetiva"” (Ibid.). A realidade daquilo que é visto, no instante em que é visto, manter-se-ia, assim, intacta - ou, ainda, menos "contaminada" pela subjetividade daquele que capta a imagem. Uma outra visão compartilhada é de Dorothea Lange ${ }^{121}$, segundo a qual todo retrato seria, na prática, um autorretrato do fotógrafo (Ibid.). Ora, conforme tal ideia, a noção de objetividade e subjetividade dialogam, pois aquilo que se expressa é, na realidade, a imagem de quem se expressou, o fotógrafo.

O retrato de Mónica escrito por Sophia Andresen parece transitar entre os dois conceitos lidos. A leitura nos indica uma descrição objetiva da personagem, mostrandonos de forma clara os seus hábitos, as suas atividades, as suas características e os seus vínculos sociais. Mónica é uma "super-mulher" com ares aristocráticos. Em sua eficácia, ela consegue manter os cuidados pessoais, os compromissos e festas do círculo a que pertence e ainda a sua articulação política com o "Príncipe deste Mundo", uma referência à representação de Salazar. A apresentação objetiva, entretanto, revela também, como observa Lange em sua citação, aspectos relativos aos valores da narradora, o que ocorre

\footnotetext{
120 László Moholy-Nagy (Hungria, 1895-1946) foi um designer, pintor e fotógrafo pioneiro em seus campos, reconhecido pelo seu trabalho na escola Bauhaus. Era um artista que buscava a interação entre a arte, a tecnologia e a indústria e, em seu trabalho, utilizava-se de técnicas de efeito - como o uso de colagens e de instrumentos - que criavam um impacto na impressão de suas fotos. (Cf. Passuth, Krisztina. Moholy-Nagy. Trans. London: Thames and Hudson, 1985).

121 Dorothea Lange (EUA, 1895-1965), fotógrafa e documentarista, conhecida pelo seu trabalho de descrição e de imagens das consequências da Grande Depressão. (Cf. Hudson, Berkley (2009). Sterling, Christopher H. (ed.). Encyclopedia of Journalism. Thousand Oaks, Calif.: SAGE). Disponível em: https://archive.org/details/encyclopediajour00ster. Acesso em: ago 2020.
} 
por meio da aguda ironia com a qual descreve a mulher "extraordinária" (ANDRESEN, 2010, p. 111):

\begin{abstract}
Mónica é uma pessoa tão extraordinária que consegue simultaneamente ser boa mãe de família, ser chiquíssima, ser dirigente da "Liga Internacional das Mulheres Inúteis", ajudar o marido nos negócios, fazer ginástica todas as manhãs, ser pontual, ter imensos amigos, dar muitos jantares, ir a muitos jantares, não fumar, não envelhecer, gostar de toda a gente, gostar dela, dizer bem de toda a gente, toda a gente dizer bem dela, colecionar colheres do século XVII, jogar golfe, deitarse tarde, levantar-se cedo, comer iogurte, fazer ioga, gostar de pintura abstrata, ser sócia de todas as sociedades musicais, estar sempre divertida, ser um belo exemplo de virtudes, ter muito sucesso e ser muito séria. (Ibid.)
\end{abstract}

De modo objetivo, como indica Moholy-Nagy, a narradora mantém o registro claro da descrição na maior parte do texto, porém, as características da protagonista, oferecidas por meio da exaltação de todas as suas incríveis habilidades, mostram-se, como vimos, pelo olhar irônico. O leitor questiona-se a todo momento se as características de Mónica são, realmente, louváveis e até passíveis de serem reais. A leitura nos indica que não, a ironia revela-se uma crítica sagaz.

Essa estratégia, presente na totalidade do texto, aponta para os valores prezados pela narradora, como se observássemos, por meio de sua crítica, um retrato negativo da personagem apresentada no conto, consoante às ideias de Lange. Atuando como um fotógrafo, a narradora exprime, em seu caráter irônico, uma imagem inversa à de Mónica, por meio da qual podemos reconhecer aspectos éticos e políticos do projeto poético de Sophia Andresen. A "fotografia" que temos de Mónica mostra-se, utilizando termos de Sontag (2004, p. 70) um "instrumento questionador e intrépido", estabelecendo relações com temas que constroem não apenas a temática de Contos Exemplares como também o ideário político da autora, como buscaremos mostrar.

Logo na abertura do conto, Mónica é descrita a partir de uma longa enumeração de qualidades e hábitos que são vistos como exemplares na opinião da alta burguesia e da classe aristocrática. Várias pessoas são parecidas com ela, porém a narradora nos indica: "Mas são só a sua caricatura. Esquecem-se sempre ou do ioga ou da pintura abstrata" (Ibid.). Ainda que a protagonista seja o retrato de uma socialite perfeita, Rocha observa que podemos ler sua descrição como um recurso alegórico utilizado pela autora: "é através da referência à actuação duma mulher que se retratam as qualidades da classe 
social a que ela pertence (1980, p. 35). Em seus jantares, “cada lugar é um emprego de capital" (ANDRESEN, 2010, p. 112), isto é, as relações sociais travadas por Mónica em seu círculo são, antes de tudo, pautadas pelos interesses econômicos, indicando uma leitura crítica da autora relativa aos vínculos sociais criados na alta burguesia, o que fora igualmente relatado no conto "O Jantar do Bispo".

As relações não são entre homens, e sim entre os interesses de cada um e os benefícios que cada conexão pode trazer. Nesse mesmo sentido, mostra-se a figura do marido da personagem, "um pobre diabo que Mónica transformou num homem importantíssimo" (Ibid., p. 113). É ela quem o controla, direciona-o e aconselha-o, e os trunfos desse sucesso são, na realidade, da esposa, e não de seu cônjuge. O casamento das duas personagens é como uma sociedade, como observa a autora, pautado no "mundo dos negócios”, que é "bem-pensante” (Ibid.)

Outro aspecto observado por Rocha (1980, p. 35) no que tange à alegoria é a relação política desempenhada por Mónica com o Príncipe deste Mundo. Ambos se encontram e mantêm longas conversas impregnadas de uma certa intimidade. "Ela é sua partidária fiel, cantora das suas virtudes, admiradora de seus silêncios e de seus discursos" (ANDRESEN, 2010, p. 113). Representando o poder econômico das classes favorecidas, a personagem relaciona-se intimamente com o poder político, o poder ditatorial desempenhado pelo Príncipe deste Mundo: "É natural que ele mostre publicamente a sua gratidão por Mónica. Todos sabemos que ela é o seu maior apoio, o mais firme fundamento do seu poder (Ibid., p. 114). O capital, cuja representação ocorre por meio das ações e qualidades da protagonista, são a base do poder político que busca se manter vigente justamente para a manutenção de privilégios da classe à qual Mónica pertence.

Sua influência está presente nas ações políticas: "pode-se dizer que em cada edifício construído neste tempo houve sempre uma pedra trazida por Mónica” (Ibid., p. 113). Nessa metáfora, podemos compreender a alegoria da personagem como o poder econômico, ela é parte do fundamento de cada obra feita nesse período, isto é, de cada ação, de cada estratégia para a manutenção do poder. É interessante, entretanto, notar que a narradora deixa claro que a relação entre Mónica e o Príncipe deste Mundo é apenas de amizade, de apoio, pois ela é "seriíssima" e ele, um "homem austero e casto" (Ibid.). O que os une, segundo o texto, não é o desejo de amor, e sim "uma vontade sem amor" (Ibid., p. 114).

De tal "vontade sem amor", podemos pensar em dois elementos que marcam os Contos Exemplares: o amor cristão e a busca pelo poder pela classe dominante política- 
economicamente. Uma passagem anterior a esse trecho mostra que Mónica, para ser a "super-mulher", renunciou à poesia, ao amor e à santidade. De acordo com a narradora, “a poesia é oferecida a cada pessoa só uma vez e o efeito da negação é irreversível. O amor é oferecido raramente e aquele que o nega algumas vezes depois não encontra mais" (ANDRESEN, 2010, p. 111-112). Não há um detalhamento na história de Mónica que nos permita perceber de que modo esses elementos foram recusados. Porém, as suas consequências são expressas no texto, a exemplo da relação da protagonista com seu marido, uma sociedade, um vínculo de negócios, de aparência e de manutenção do poder.

Entretanto, a construção da personagem de Mónica como uma alegoria do capital é particularmente interessante se considerarmos a sua relação marital. Engels (s/d, p. 8595) observa que o casamento burguês molda-se, pouco a pouco, na perda da influência e da liberdade da mulher em relação a seu cônjuge do sexo masculino, evidenciado, assim, o poder do homem sobre seus filhos e seus bens, que seriam herdados. Fortaleceram-se, desse modo, o casamento entre indivíduos da mesma classe, sem a consideração do amor sexual ou romântico como um fator decisivo. Ora, ainda que Engels reconheça que, dentro do casamento burguês, houve uma certa liberdade dentro da mesma classe para que os interessados pudessem, ao menos, escolher seus cônjuges, o papel da mulher nesse tipo de relação mantinha-se subjugado ao homem, e o relacionamento ainda seria, na prática, um contrato entre interessados na manutenção do poder econômico da propriedade privada e dos bens adquiridos.

Mónica, entretanto, é uma exceção dentre tal modelo marital, pois é ela quem organiza as bases do poder do casal. O marido é visto como um fantoche, fora transformado por ela em um homem importantíssimo, porém é dela o mérito. Ela transita entre banqueiros, entre manicures, caixeiros e cabelereiros. Está a par de todas as informações, utilizando-as convenientemente. A conquista de seu marido é, na realidade, dela. Nesse sentido, o papel de Mónica como mulher em um relacionamento burguês é atualizado por Sophia Andresen na construção da personagem como uma alegoria do capital.

A autora inova em determinar tal papel a uma personagem feminina, uma vez que, a princípio, o capital poderia ser representado por um homem burguês, ao qual é atribuído geralmente o poder econômico e a influência política. Mas não, Mónica é quem controla e tece todas as relações econômicas e políticas para que seu marido seja o representante ideal daquilo que se espera de um casal da alta classe. Uma personagem feminina está em uma posição importante para o equilíbrio das relações de poder: ela se move entre classes. 
Do mesmo modo que oferece um jantar finérrimo a políticos e banqueiros, ela se relaciona com cabelereiros, manicures, empregados da casa. O meio feminino e doméstico tornamse ferramentas para o meio socioeconômico, mantendo assim uma relação de poder em ambas as classes alta e baixa, como o próprio fluxo do capital. Quando ela está na praia, afinal "o próprio Sol se enerva” (ANDRESEN, 2010, p. 112).

Para tanto, porém, Mónica renunciou ao amor na vida, não somente o amor romântico, mas outras formas de tal sentimento. O amor aos amigos é igualmente inexistente: "todos os seus amigos são úteis". Novamente, a relação que se coloca entre Mónica e o seu círculo social é a utilidade, a conveniência. O vínculo traz aquilo que é benéfico no campo da posição social e do poder que se emana. Mónica obtém vantagens em suas amizades e ter relações com ela é também uma vantagem, um trunfo, pois ela está em um lugar privilegiado. "Como um instrumento de precisão, ela mede o grau de utilidade de todas as situações e de todas as pessoas" (Ibid.). Seus jantares, sempre bem sucedidos, são convenientes, “cada lugar é um emprego de capital” (Ibid.).

Para tais eventos, Mónica sempre convida pessoas de ideias consonantes às suas. Não há discussões inoportunas desse modo. Como um estrategista extremamente inteligente, ela coloca essa qualidade "ao serviço da estupidez" (Ibid.), de modo que seu poder, como o ser racional e eficaz que é, garante o seu domínio, ou seja, ela se sobrepõe acima daqueles que são considerados estúpidos. Suas relações são estratégicas, não afetivas. Pessoas adquirem o estatuto de objetos, são reduzidas às suas posições sociais, às suas vantagens, o que lhe garante o controle, o poder, o sucesso em sua rede de influências.

Outra renúncia feita por Mónica é à santidade. Podemos considerar nesse aspecto mais uma forma de amor, o amor pelo próximo, um princípio cristão que se mostra presente nos Contos Exemplares desde seu primeiro conto, “O Jantar do Bispo". Uma antítese e uma objetificação ajudam-nos a compreender tal elemento na seguinte passagem: "É por isso que Mónica, tendo renunciado à santidade, se dedica com grande dinamismo a obras de caridade" (Ibid., p. 113). As ideias opostas em "renunciar à santidade" e "dedicar-se à caridade" mostram que a protagonista pratica o ato da benevolência sem ter, de fato, a compaixão e a generosidade. Pelo contrário, ela o desempenha de forma "dinâmica", uma noção que pode ser aplicada tanto a pessoas eficazes como a máquinas eficientes e produtivas. De modo figurado, o adjetivo "dinâmico" pode ser associado a conceitos como "agilidade", "diligência", 
"empreendedorismo" e "produtividade" 122 . Tais elementos são atribuídos à maquinaria de uma fábrica ou a funcionários que trabalham de modo manual e repetitivo, de modo a tornarem-se alheios de sua própria produção das mercadorias, o que nos remete ao conceito de alienação desenvolvido por Marx ${ }^{123}$.

A alienação, na teoria marxista, reflete, em um primeiro momento, a ação de homem de perder a posse da mercadoria por ele produzida, mas expande-se à ideia de que um homem alienado é aquele que está alheio à natureza em que vive e a outros seres humanos. Essa quase objetificação de Mónica no âmbito da caridade minimiza ou apaga completamente o caráter cristão da compaixão e do amor ao próximo, mostrando-a alheia ao outro. Ela produz (grifo nosso) a caridade com eficiência e agilidade, e não pela generosidade e pelo amor ao seu semelhante. Novamente, temos uma conexão com o primeiro conto do livro: a caridade das aparências e da conveniência.

Como a narradora bem nos detalha, Mónica "faz casacos de tricot para as crianças que seus amigos condenam à fome" (ANDRESEN, 2010, p. 113). A questão da desigualdade socioeconômica é, mais uma vez, evocada na obra. Como indica Clara Rocha, o tema da desigualdade social é parte de um conceito mais amplo na obra andreseniana, a questão da justiça. Segundo a crítica,

Servindo-se de alusões ("O Príncipe deste Mundo"), de figuras alegóricas e simbólicas, e ainda de personagens com um fundo verdadeiro (personagens "à clef", como Mónica), a autora retrata o odioso da camada social dominante e exprime a revolta perante um estado social de injustiça, de podridão, de mesquinhez e de ditadura [...] (ROCHA, 1980, p. 20)

No trecho em questão do conto, observamos ainda a relação de classes entre aqueles que praticam essa suposta e aparente caridade e as crianças que receberiam as ofertas dos casacos tricotados. Mónica faz os casacos às crianças que passam fome por culpa de seus amigos, sejam eles banqueiros, donos de indústrias, donos de terra, políticos. É uma crítica aguda diretamente na exploração praticada pela classe dominante sobre os mais desfavorecidos, que padecem ou pela falta de trabalho e assistência do Estado, ou pelos míseros salários que recebem como mão de obra braçal nestas instituições. Conforme a narradora, “às vezes, quando os casacos estão prontos, as crianças já morreram de fome” (ANDRESEN, 2010, p. 113).

122 Cf. verbetes "dinâmico", "dinâmica” e "dinamismo”. In: Dicionário Eletrônico Houaiss da Língua Portuguesa.

${ }^{123}$ Cf. MARX; ENGELS, 2005, p. 45-47 e Dicionário do Pensamento Marxista; BOTTOMORE, s/d, p. 19. 
Do mesmo modo que, em "O Jantar do Bispo", o mendigo espera pela atenção do Dono da Casa sem obter nenhuma resposta, as crianças pobres esperam por uma ajuda real. Praticar a caridade é um ato de aparência e conveniência aos olhos da sociedade burguesa e aristocrática em nome do princípio divino da compaixão e do amor ao próximo. As crianças são, como observamos também no primeiro conto, ligadas à noção de pureza, inocência e bondade, as quais, por sua vez, suscitam ideais cristãos. Cria-se, assim, uma antítese entre "renunciar à santidade" e "dedicar-se com dinamismo à caridade". Ora, a ação de praticar o bem e a compaixão são caracteres da santidade. Porém, não é isso que demonstram Mónica e as mulheres da sua classe, que tecem casacos sem realmente se importarem com a condição desses meninos, mas, sim, fazem-no para manter a aparência de cristãs e cidadãs exemplares. Sophia Andresen recupera a temática do amor cristão como base da denúncia à exploração das classes subalternas e ao descaso do Estado com esse grupo.

$\mathrm{O}$ aspecto da desigualdade social e da justiça na obra andreseniana dialoga também, além do viés cristão, com elementos da cultura helênica que inspira a autora tanto na prosa como na poesia. Quando defende que a poesia - e a própria escrita - é uma moral, a poeta mostra que a questão política não é apenas um tema pontual dado o contexto sócio-histórico de sua obra mas também parte de seu projeto poético. Como observa Jacinto Prado Coelho (1970, p. 58), "Poesia e comunicação, poesia e entrega, poesia e acção social constituem, em Sophia, modos indissolúveis duma vocação a que obedece, com um sentido religioso do dever". Tal dever é lido, em parte, segundo a influência do pensamento cristão no conjunto de textos da autora, entretanto é também ligado a um aspecto da cultura clássica.

A partir da sua interpretação do conceito grego da physis $^{124}$, Sophia Andresen traz ao seu projeto uma noção de justiça como parte da relação de equilíbrio entre o homem, o mundo que o cerca e o divino. Tal ideia, que remonta ao espírito grego arcaico, isto é, um período cuja organização do mundo aparecia de modos muito distintos do cenário moderno. Em Hesíodo, podemos perceber como ocorre tal ordem, "o mundo é um conjunto não enumerável de teofanias, séries sucessivas e simultâneas de presença divina" (TORRANO, 2007, p. 49).

Nesse cenário, o homem convive em proximidade com as entidades divinas, estando conectado ao elemento numinoso e ao elemento natural: os fenômenos da

\footnotetext{
${ }^{124}$ Um estudo mais detalhado sobre o conceito physis e sua relação com a obra de Sophia Andresen foi anteriormente discutido por nós na dissertação de mestrado de NAHAS, 2015.
} 
natureza e as sensações do ser humano são a presença dos deuses, ocorrem na sua existência. O âmbito natural pressupõe a existência do divino:

Muito antes de o espírito grego ter delineado essa ideia, eles já consideravam as coisas do mundo numa perspectiva tal que nenhuma delas lhes aparecia como parte isolada do resto, mas sempre como um todo ordenado em conexão viva, na e pela qual tudo ganhava posição e sentido. Chamamos orgânica a esta concepção, porque nela todas as partes são consideradas membros de um todo (JAEGER, 1995, p. 11)

Desse modo, o mundo organiza-se como um todo do qual o homem é parte. A existência deste equivale-se à dos outros elementos que o rodeiam, o que compreende os outros homens. Nesta forma de pensamento, o mundo grego arcaico baseia-se na ideia de que o todo precede a parte, e a individualidade do homem torna-se importante dentro de algo maior e total.

Como já desenvolvemos em NAHAS (2015, p. 65-70), o conceito da physis é base do pensamento de Aristóteles na elaboração da obra Política, utilizando-se dessa noção para elaborar sua análise sobre a ordem e a organização dos homens na sociedade. Segundo o pensador, a finalidade da política deve ser o bem comum (1984, p. 50) e a sua acepção parte de uma relação justa entre o homem e os seus semelhantes. Assim, política, ética e justiça unem-se em uma mesma ideia, a qual pressupõe uma relação em equilíbrio entre os homens e o mundo que os rodeia (Ibid., p. 143).

A partir desses elementos do mundo helênico, conseguimos aprofundar a noção de Sophia sobre a escrita como uma ação ética. A poesia é, para a autora, "a mais funda implicação do homem no real", sendo necessariamente política (ANDRESEN, 1977, p. 77). O poeta é aquele que busca a relação verdadeira com os elementos do mundo e, por consequência, uma relação justa com os outros homens. É nesse âmbito que conseguimos compreender a ideia de justiça na poética andreseniana, aparecendo de forma evidente nas obras consideradas mais políticas da autora, como Livro Sexto (1962), Contos Exemplares e a antologia Grades (1970-71). Porém, a ela unem-se noções de generosidade e de compaixão nas quais se baseia o princípio cristão do amor ao próximo.

Em "O Retrato de Mónica", esse ideal de justiça e ética desdobra-se por meio da ironia da autora quando se refere aos atos de caridade da protagonista. Sua benevolência é aparência, é ostentação, logo é vazia. É por isso que Mónica, tendo renunciado à santidade, dedica-se ativamente à caridade, o que parece uma contradição. É algo que se espera dela como mulher exemplar da sociedade burguesa. Espera-se a piedade, mas não é esse o princípio que a motiva. Sua atuação consiste na aparência, no falso valor da 
bondade. Mónica é, lembremos, a alegoria do poder econômico, do sistema que condena essas crianças à miséria. A aristocrática tece casacos para crianças que, às vezes, já morreram de fome e de frio, do mesmo modo que o mendigo do primeiro conto jamais tem voz diante do Dono da Casa. Na ironia de Sophia Andresen, está a revolta, a não aceitação desse cenário. Mónica representa o sistema que subjuga os pobres. Na aguda crítica, a autora expressa o posicionamento político contra a resignação, o silêncio e o alheamento diante da exploração das classes desfavorecidas.

Este conto representa a denúncia e a revolta diante do tempo "em que os homens renunciam"(ANDRESEN, 2011, p. 338). Mónica é a prova de que, diante da exploração entre as classes sociais, não se pode haver um tempo de justiça e de equilíbrio entre os homens. Ela não tem nada em comum com "os humilhados e ofendidos" (Idem, 2010, p. 113). Enquanto as crianças morrem, o tempo passa e a protagonista brilha cada vez mais. "Ela todos os anos parece mais nova. A miséria, a humilhação, a ruína não roçam sequer a fímbria dos seus vestidos" (Ibid.). Novamente, uma antítese entre a morte como o fim e o rejuvenescimento como o auge da vida revela a irônica crítica da autora acerca das relações de classe no Portugal de Salazar.

A escolha do título do conto também nos sugere uma ideia interessante acerca das relações de classe. O retrato é um objeto amplamente mostrado nas casas de diferentes classes sociais. Como vimos em “O Jantar do Bispo", as paredes da casa eram repletas de retratos das gerações ancestrais do Dono da Casa. Em Finisterra, a casa que seria entregue ao executor fiscal, que estava se desfazendo, dado seu estado de conservação, também continha na parede o retrato imponente do avô, cuja voz reverberava nas palavras do tio. As famílias abastadas costumam expor seus antepassados em retratos como uma espécie de legitimação do poder patriarcal e geracional. É a ostentação do poder. No entanto, as famílias mais humildes também são conhecidas por expor o retrato de seus parentes já mortos. Numa citação encontrada na Macmillan's Magazine, separada por Susan Sontag (2004, p. 109), temos a seguinte ideia:

Qualquer um que conheça o valor da afeição familiar nas classes sociais inferiores e tenha visto uma coleção de pequenos retratos pregados acima da lareira de um trabalhador [...] sentirá talvez comigo que, em contraposição às tendências sociais e industriais que todos os dias solapam as afeições familiares mais saudáveis, a foto de seis pence $e^{I 25}$ faz mais em favor dos pobres do que toda a filantropia do mundo.

${ }^{125}$ Six pence equivale a seis centavos na moeda britânica. 
Em outra citação (SONTAG, 2004, p. 101), Schopenhauer afirma que a fotografia "oferece a satisfação mais completa da nossa curiosidade", pois a suposição de que o homem exterior é um retrato do homem interior, "e o rosto, uma expressão e uma revelação de todo o caráter" lhe parece bastante plausível e segura para ser levada adiante. Essa ideia é, no entanto, reorganizada por Sophia Andresen em uma nova perspectiva. A beleza e a jovialidade que Mónica ostentava refletem o interior vazio de uma mulher que simboliza uma classe - em busca de ascensão, privilégios e poder dentro de uma sociedade que enriquece através da exploração dos menos favorecidos.

Sua beleza e seu sucesso são apenas aparência, assim como tudo ao seu redor. Suas ações são voltadas para o exterior, para a ostentação. São vazias de valores caros à autora, como ela cita no próprio conto: a poesia, o amor e a santidade. Lúcia, em "A História da Gata Borralheira”, também renunciou a uma vida livre e natural em favor da ascensão social e da riqueza. O interior de Mónica é desabitado de princípios como a bondade e o respeito pelos seus semelhantes. Há apenas a conveniência dos privilégios sociais e conivência com o poder político-econômico que age em detrimento de um mundo justo, ético e poético.

Se a riqueza é abordada a partir de um modelo ironizado em "O Retrato de Mónica", a pobreza mostra-se demasiadamente desumana em outro conto da mesma obra, "O Homem", no qual a narradora capta um instante único de uma pessoa marcada pela carência absoluta. Em uma tarde no fim de novembro, "já sem nenhum outono" (ANDRESEN, 2010, p. 137), apontando para a chegada do inverno, temos a narradora que anda por meio da multidão da cidade, que se erguia em paredes de "pedras escuras" (Ibid.). Ela passava com pressa, entre centenas de pessoas, quando se depara, à sua frente, com "um homem muito pobremente vestido que levava ao colo uma criança loira, uma daquelas crianças cuja beleza quase não se pode descrever" (Ibid.). Esse homem era "extraordinariamente belo" e tinha cerca de trinta anos (Ibid.). Em seu rosto, segundo a narradora, "estavam inscritos a miséria, o abandono, a solidão" (Ibid.).

Tal abandono e pobreza percorrem a descrição física do homem, cuja roupa, um fato $^{126}$, tendo perdido a cor de tanto ser utilizado, apresentava nuances de verde e mostrava "um corpo comido pela fome" (ANDRESEN, 2010, p. 137-138). Seu cabelo era castanho-claro, separado ao meio e levemente comprido. Seu rosto, com uma barba que já crescia há alguns dias, era "estreitamente esculpida pela pobreza", mostrando "o

\footnotetext{
${ }^{126}$ Fato é termo português para o vestuário masculino correspondente a um terno na variação brasileira.
} 
belo desenho dos ossos" (Ibid., p. 138). Seus olhos eram claros e muito belos, "luminosos de solidão e de doçura" (Ibid.).

No momento em que os olhos da narradora captam a imagem do pobre homem, ele levanta a cabeça e olha para o céu:

Era um céu alto, sem resposta, cor de frio. O homem levantou a cabeça no gesto de alguém que, tendo ultrapassado um limite, já nada tem para dar e se volta para fora procurando uma resposta: a sua cara escorria sofrimento. A sua expressão era simultaneamente resignação, espanto e pergunta. (Ibid.)

Tendo passado pelo limite das necessidades básicas, o homem volta-se para o céu em um sinal de questionamento e busca, já expressando a desesperança em suas feições e no seu corpo. Dentro de seu desalento, era como se procurasse respostas sobre por que viver daquele modo. Ele caminhava muito lentamente enquanto mantinha sua cabeça voltada para cima. Mas não se obtinha nenhuma resposta: o céu eram "planícies e planícies de silêncio" (Ibid.).

A narradora conta que a imagem deste homem passou por ela em questão de instantes, mas ela se lembra nitidamente da sua figura, dos seus gestos e do seu olhar de desconsolação. Ela observa, porém, um intenso contraste: enquanto aquele desconhecido passava lentamente pelo centro da cidade, uma multidão de pessoas ia na outra direção, passavam sem notá-lo. "Rios de pessoas passavam sem o ver" (Ibid.) e ele permanecia em seu caminhar lento, sozinho. A única pessoa que parou para realmente o olhar foi a narradora, que estava prostrada em meio a passagem, com centenas de pessoas indo contra a sua direção.

Era impossível manter-se naquela posição, pois a multidão, embora ignorasse o homem, via a narradora, que claramente atrapalhava o fluxo. Então, "como o nadador que é apanhado numa corrente desiste de lutar e se deixa ir com a água, assim eu me deixei de opor ao movimento da cidade e me deixei levar pela onda de gente para longe do homem (Ibid., p. 139). Porém, a imagem da pobreza e desolação permaneciam na mente da narradora. Havia algo no homem que ela reconhecia e, por isso, evocou todos os lugares onde tinha vivido, quadros, fotografias, livros, buscando em todos os recantos da memória uma lembrança daquela pessoa, sem nada conseguir.

E do fundo da memória, trazidas pela imagem, muito devagar, uma por uma, inconfundíveis, apareceram as palavras - Pai, Pai, por que me abandonaste? (ANDRESEN, 2010, p. 140) 
O olhar daquele homem, com a sua dor, a sua tristeza e a sua solidão, foi associado, pela memória da narradora, às palavras de Cristo na cruz. Ela nos conta que o homem, "levantou a cabeça no gesto de alguém que, tendo ultrapassado um limite, já nada tem para dar e se volta para fora procurando uma resposta” (Ibid., p. 138). Estava abandonado, em um estado de carência profundo, e o limite da indigência fazia-o indagar, ainda que silenciosamente, ao céu "alto, sem resposta, cor de frio" (Ibid.).

A associação feita pela memória às palavras de Jesus em sofrimento retoma o relato da crucificação descrito no livro do apóstolo Marcos. Pôncio Pilatos, após açoitar o filho de Deus, voltou-se à multidão que acompanhava o julgamento e perguntou: "Vocês querem que eu lhes solte o rei dos Judeus?"127 E as pessoas bradavam, pediam que ele fosse crucificado. O imperador romano ainda questionou que crime Jesus teria cometido, mas a resposta que vinha do agrupamento de pessoas era a mesma: "Crucificao"128. Tentando agradar o povo, Pilatos ordenou aos soldados que crucificassem o homem.

Jesus seguiu o caminho até o monte onde seria crucificado sendo ridicularizado e humilhado pelos soldados responsáveis pela pena. Já pregado à cruz, ouvia das pessoas que lá estavam: "Ora, você que destrói o templo e o reedifica em três dias, desça da cruz e salve-se a si mesmo"129. Era zombado também pelo chefe dos sacerdotes, os quais observavam que ele era capaz de salvar aos outros, mas não a si mesmo. Segundo o livro de Marcos, Jesus fora crucificado às nove horas da manhã e, às três da tarde, diante do desespero, das dores, dos insultos e da humilhação, gritou aos céus: "Eloí, Eloí, lamá sabactâni?", que significa: "Meu Deus! Meu Deus! Por que me abandonaste?"130.

Essas palavras surgiram na memória da narradora de forma inconfundível (ANDRESEN, 2010, p. 140). O desespero do homem o levava a indagar aos céus ou, talvez, a Deus, sem ter mais nenhuma esperança. A sua invisibilidade diante de uma multidão era a prova da dor e do abandono; a pobreza extrema, a sua chaga. Com a tocante analogia às palavras de Jesus em seu momento de martírio, o conto "O Homem" evoca símbolos já trabalhados na obra Contos Exemplares que reaparecem para abordar a miséria presente em Portugal anteriormente ao período salazarista e também durante esse governo. $\mathrm{O}$ encontro da narradora com o homem expôs o rosto da escassez e da fome de um povo que era relegado. Em uma entrevista a Maria Arminda Passos, Sophia Andresen

\footnotetext{
${ }^{127}$ Bíblia Sagrada. Livro de Marcos, capítulo 15, versículo 9.

128 Ibidem, versículo 14.

129 Ibidem, versículos 29 e 30.

130 Ibidem, versículo 34.
} 
relata que "O Homem" surge "tal e qual" ao encontro que teve com um homem na mesma condição ainda durante a infância. Segundo a autora, ela se propôs a escrever

Tal e qual como tinha acontecido. Não inventar nada, não compor, escrever como quem faz um relato. Aconteceu no Porto ao pé da igreja que fica ao canto da praça, em frente da estação de São Bento. O homem estava ali, numa esquina. Esse encontro talvez seja o primeiro de que me lembro. [...] Na minha infância havia uma certa miséria não escondida, que depois desapareceu. Foi arrumada não se sabe para onde. Pelo Estado Novo. (ANDRESEN, 1982, p. 03)

Essa pobreza era, para a autora, uma "interrogação enorme, um escândalo no meio do mundo e da infância" (Ibid.).

A relação entre a influência cristã e a política na obra andreseniana percorre os Contos Exemplares assim como a obra poética, e Sophia indica, desta vez em entrevista a Eduardo Prado Coelho, que a educação católica cristã predispõe para a política "na medida em que nos responsabiliza" (ANDRESEN, 1986, p. 73). A autora explica que:

Quem ouve desde pequena que se 'Me abandonaste quando eu tinha fome, se Me abandonaste quando eu tinha sede não Me encontrarás no reino dos céus' é necessariamente posta perante uma exigência em relação aos outros (Ibid.)

Em "O Homem”, o indivíduo pobre que passa pela multidão e é ignorado suscita a imagem de Cristo na terra, representante de Deus, mas abandonado e crucificado a pedido do próprio povo. O mendigo caminha com uma criança ao colo em meio a uma multidão que não os apercebe, as pessoas passam e continuam no fluxo enquanto ele para e olha desesperado para o céu. O movimento das pessoas se mantém, elas andam com pressa e desviam do homem que se encontra parado, em total desesperança. O fluxo é como uma analogia à cegueira dessas pessoas, que não prestam atenção ao seu semelhante, que não se apercebem, ou ainda, que ignoram o sofrimento do outro. Totalmente invisível, esse homem é duplamente ignorado: pela multidão e pelo país, isto é, por seus governantes. Sua esperança é olhar ao céu e questionar a Deus se Ele também o abandonará. Atrapalhando o movimento das ruas, o homem acaba por desmaiar. A criança que estava em seu colo começa a chorar e tenta esconder seu rosto no vestido, já sujo pelo sangue que saiu da boca do mendigo. Neste momento, o fluxo para e forma um círculo em torno do homem caído. Nesse momento, a narradora já não consegue acompanhar o que se passa na situação, ouve apenas o barulho de uma ambulância que leva o homem e a criança. 
Conforme observa Clara Rocha (1980, p. 41), a simbologia do círculo formado em torno do corpo do homem que cai:

Símbolo antigo [...], o círculo representa neste caso as relações entre o homem singular e a multidão anônima, isto é, entre Cristo e os homens. Tais relações caracterizam-se pela individualização do Homem (por contraste com a multidão) - e por isso aquele se encontra no meio do círculo -; pela evidenciação do Homem singular na morte, depois de ter passado a vida despercebido no seio da torrente humana; o seu lugar no centro do círculo acentua o caráter exemplar de sua queda [...].

Do mesmo modo que em "O Jantar do Bispo" temos o mendigo que desaparece como se sua presença tivesse sido uma aparição, e seus modos, seu olhar e seu questionamento sugeririam uma analogia com a imagem de Cristo, novamente observamos a relação do homem marcado pela miséria e pela solidão pelo caráter cristão. O homem é invisível diante da sociedade e, apenas no momento de sua morte, chama a atenção da multidão. Sua morte é exemplar, porém somente a partir do olhar da narradora, que vê em sua face esculpida pela miséria o abandono e a desesperança de Cristo em sua crucificação. Há ainda a presença da criança, que, segundo Rocha, aparece como imagem da "pureza própria daqueles que ainda não estão marcados pela mesquinhez e pela podridão do mundo dos adultos (1980, p. 41).

A construção do conto, a partir de uma linguagem muito clara e direta, característica da obra andreseniana, revela alguns contrastes que nos permitem ressaltar uma temática social crítica sobre a relação da pobreza e da riqueza, permeada, como toda a obra Contos Exemplares. Temos, desde o primeiro momento, o contraste entre o homem - singular e solitário - e a multidão. No início do conto, observa-se ainda o contraste do ritmo desses dois elementos: enquanto o grande grupo de pessoas passa em velocidade rápida, o homem solitário está andando lentamente, e a narradora, por sua vez, também tenta diminuir sua velocidade para observá-lo. Mostra-se uma imagem de fluxo e contrafluxo, que pode ser lida como um revelador da condição social.

O tempo também contrasta: o conto é narrado no passado, quando a narradora conta que captou, em um instante, a imagem do senhor pobre. Ainda, em um breve momento, o homem morre, a multidão se aglomera para observá-lo. Ele logo desaparece, levado por uma ambulância, e as pessoas dispersam-se, como se nada houvesse. Porém, no final do conto, a narradora nos revela: "Muitos anos se passaram. O homem certamente morreu. Mas continua ao nosso lado. Pelas ruas" (ANDRESEN, 2010, p. 141). O contraste entre instante e permanência e passado e presente apontam para algumas 
questões críticas acerca da pobreza na sociedade. Apontam ainda o caráter divino deste homem pobre cujo sofrimento é análogo ao de Cristo.

A permanência do homem pelas ruas pode ser lida como uma metáfora da miséria que se mantém em todos os lugares, apesar da cegueira diante da condição precária de vida de indivíduos como o homem morto. A visão crítica de Sophia ressalta o modo como as classes desfavorecidas mantêm-se invisíveis aos olhos da multidão. Ela já havia demonstrado essa posição por meio do questionamento sobre a falsa caridade, mas, em "O Homem", ela o retoma a partir de dois fenômenos analisados pela crítica como invisibilidade pública e aporofobia.

A invisibilidade pública é uma espécie de desaparecimento psicossocial de um homem em meio a outros homens. Fernando Braga da Costa, doutor em psicologia social, estudou a fundo tal temática no que tange às relações entre a pobreza e o trabalho. Em sua pesquisa, o autor analisou de que modo pessoas que trabalham como garis sentem-se diante da população mais favorecida. O próprio pesquisador fez o trabalho de campo trabalhando juntamente com os garis e revelou que, durante todo o período em que desenvolveu essa atividade, era ignorado por todas as pessoas em seu campus universitário. Amigos, colegas e professores de Costa passavam por ele, vestido como um gari, e não notavam sua presença, não lhe dirigiam a palavra sequer para um simples bom dia. Era como se Costa, como gari, não existisse aos olhos dessas pessoas. Sua tese, defendida na Universidade de São Paulo em 2008, relata seu trabalho de campo e ainda a análise do relato de outros garis que trabalham na universidade. Costa nos dá algumas ferramentas para compreender tal fenômeno, apontando para a ideia de que tal invisibilidade é a expressão aguda de problemas inerentes à sociedade capitalista (COSTA, 2008, p. 10).

Segundo o pesquisador, a invisibilidade pública é a “expressão pontiaguda de dois fenômenos que assumem caráter crônico nas sociedades capitalistas: a humilhação social e a reificação (Ibid., p. 15). É um fenômeno histórico, um processo de longa duração no qual se rebaixa a percepção de outra pessoa, sobretudo daqueles que exercem trabalhos manuais de baixa remuneração e de pessoas em situação de rua. Configura-se pela humilhação social e a reificação do outro, cuja subjetividade é ignorada pela "cegueira pública" (Ibid.). Para Costa, tal fenômeno se trata de uma forma de violência simbólica e material que oprime cidadãos das classes menos favorecidas, seja na cidade ou em regiões rurais (Ibid., p. 16). 
O pesquisador observa que a invisibilidade pública, como construção social e psíquica - "tem a força de ressecar ${ }^{131}$ expressões corporais e simbólicas dos humanos então apagados. "Pode abafar a voz e baixar o olhar. Pode endurecer o corpo e seus movimentos. Pode emudecer os sentidos e fazer fraquejar a memória. Faz esmorecer em todos estes níveis - o poder de aparição de alguém $^{132}$ (Ibid.). Esse fenômeno é fundado e mantido por motivações sociais e psicológicas, "por antagonismos de classe mais ou menos conscientes, mais ou menos inconscientes" (Ibid.). Nesse sentido, podemos compreender a descrição que a narradora faz do homem, que está ressecado, cujo rosto é esculpido pela pobreza, mas também por sua invisibilidade dentro da sociedade, que o marginaliza, deixando-o abandonado, sem esperanças.

Na mesma perspectiva, José Moura Gonçalves Filho analisa a invisibilidade pública por meio da ideia do olhar na construção interpessoal da subjetividade de uma outra pessoa. Segundo o autor,

O olhar personalizante, olhar de reconhecimento interpessoal, perde espaço para o olhar humilhante, olhar objetivante, olhar reificado e reificante. A invisibilidade pública é cegueira psicossocial, parece ser tanto mais automatizada quanto menor for o sentimento de comunidade que o cego tenha com o indivíduo que não foi visto. Parece haver mais consciência do cego sobre sua cegueira quanto maior for o grau de comunidade em que ele possa ingressar com quem ficou apagado. (COSTA, 2004, p. 22)

Assim, a ideia de que o outro faça parte da mesma comunidade que o sujeito pode acarretar a visão e o reconhecimento da subjetividade e do lugar do outro na sociedade, e a cegueira social implica uma condição aos indivíduos desfavorecidos de marginalização e de isolamento, que reforçam sua situação de precariedade.

O trabalhador braçal e o cidadão em situação de rua são, comumente, marginalizados na sociedade capitalista. Discutimos anteriormente a animalização do trabalhador braçal na figura de Lobisomem, em Casa na Duna, de Carlos de Oliveira. Tal animalização surge como um fenômeno similar à invisibilidade pública, uma vez que coloca o outro humano em um patamar de subjugação e de inferioridade. Suas mazelas são rapidamente ignoradas, sua presença é normalmente evitada e suas demandas não são ouvidas. Em situação de mendicância, o homem, de Sophia Andresen, consegue ser notado somente no ápice do seu sofrimento, no momento de sua morte. O corpo caído no

\footnotetext{
${ }^{131}$ Grifo feito pelo autor.

132 Idem.
} 
meio da rua atrapalha fisicamente a locomoção do fluxo de pessoas e é apenas como obstáculo que ele passa a ser notado.

Seu corpo morto é a pedra no meio do caminho da sociedade burguesa. Suas necessidades são ignoradas, ele é relegado, e só no momento da sua morte torna-se visível. Não por suas demandas como humano e cidadão, e sim como um entrave ao movimento de vai e vem daqueles que estão com pressa. A situação de pobreza é um empecilho, algo a ser ignorado ou escondido. Ignorar a pobreza, mascará-la, é uma crítica que Sophia Andresen fez ao Estado Novo de Salazar, como demonstra a entrevista a Maria Arminda Passos. A cegueira social em relação à miséria e a política pública de mascarar cidadãos em estado de pobreza instigaram a autora a buscar respostas, talvez não encontradas, mas que lhe fizeram, de certo modo, uma voz de denúncia e crítica.

Como observa Costa, a invisibilidade pública é uma forma de violência simbólica, que pode ser física também, ligada à reificação aguda de um humano em relação aos outros que o observam. Em um primeiro momento, a reificação é "o ato (ou resultado do ato) de transformação das propriedades, relações e ações humanas em propriedades, relações e ações de coisas produzidas pelo homem, que se tornaram independentes (e que são imaginadas como originalmente independentes) do homem e governam sua vida"133. Esse processo estende-se a uma significação mais ampla, compreendendo a transformação de seres humanos em seres semelhantes a coisas, sendo a forma mais radical de alienação, sobre a qual discutimos anteriormente. Nos volumes de $O$ Capital, Marx analisa o modo com as relações interpessoais são reificadas a partir das relações do capital que envolvem a produção como foco e relegam aqueles homens que fazem o produto a seres "coisificados" em sua condição de mão de obra. Para Lukács, esse pensamento, intensificado pelo desenvolvimento capitalista, atinge maiores estágios:

À proporção que o sistema capitalista constantemente produz e se reproduz economicamente nos níveis mais altos, a estrutura da reificação mergulha cada vez mais profundamente, mais inexoravelmente e mais definitivamente na consciência do homem (2012, p.93).

Desse modo, não somente as relações entre mercadoria - produção - capital são pensadas dessa forma, e sim todas as relações interpessoais dentro do contexto capitalista.

Do ponto de vista das relações interpessoais, a reificação pode ser explicada, conforme explica Costa, a partir da ideia de que "somente seres humanos já reduzidos e

133 “reificação" - artigo de Gajo Petrovic para o Dicionário do Pensamento Marxista. 
tidos como objeto podem parecer impotentes na capacidade de se fazerem interpelar como humanos e de interpelarem outros humanos como iguais (2008, p. 17). Podemos pensar ainda que este processo é simultâneo a outro, o de desumanização. Na cegueira social, o outro, de uma classe inferior, já não é visto como um humano que tem suas necessidades básicas, sua voz não é ouvida, seu corpo resseca física e moralmente. É um processo de subjugação que, aos poucos, desumaniza aquele que está em situação de risco, em situação precária. Ele deixa de ser reconhecido como um homem, um cidadão, um lugar de fala e é, paulatinamente, esvaziado de humanidade.

Outra corrente crítica que estuda os processos de invisibilidade social trabalha com o conceito de aporofobia, ou seja, o rechaço, o desprezo e o temor de pessoas pobres. Esse desprezo parte da ideia, também intensificada pela sociedade capitalista, que as relações interpessoais dependem de troca. Relaciono-me com o outro em troca de algo, de algum elemento que ele possa me oferecer e vice-versa. Ora, a pessoa em situação de precariedade, em princípio, não tem nada a oferecer. O objetivo dessa relação - reificada - não se concretiza. Se a pessoa pobre não pode dar nada em troca, ela é, por isso, "excluída de um mundo construído sobre o contrato político, econômico ou social de dar e receber, nos quais somente podem entrar aqueles que parecem ter algo interessante a devolver como retorno" (CORTINA, 2017, s/p).

É importante ressaltar que essa temática analisada por Sophia Andresen aparece não somente em Contos Exemplares mas também na sua obra poética. No poema "Esta Gente", do livro Geografia (1967), imagens do alheamento, da reificação, da pobreza que desenha o rosto das pessoas em situação de miséria é trabalhado pela autora como algo que a impulsiona a reivindicar, a denunciar:

Esta gente cujo rosto

Às vezes luminoso

E outras vezes tosco

Ora me lembra escravos

Ora me lembra reis

Faz renascer meu gosto

De luta e de combate

Contra o abutre e a cobra

$\mathrm{O}$ porco e o milhafre

Pois a gente que tem

$O$ rosto desenhado

Por paciência e fome

É a gente em quem 
Um país ocupado
Escreve o seu nome
E em frente desta gente
Ignorada e pisada
Como a pedra do chão
E mais do que a pedra
Humilhada e calcada
Meu canto se renova
E recomeço a busca
De um país liberto
De uma vida limpa
E de um tempo justo (ANDRESEN, 2011, p. 458)

Elaboramos a análise deste poema no âmbito da pesquisa de nossa dissertação de mestrado (NAHAS, 2015, p. 132), porém podemos destacar alguns pontos importantes que coadunam com a leitura do conto "O Homem". O povo, que pode ser lido como o povo português se considerarmos o contexto de publicação da obra, tem o rosto luminoso e tosco, quase uma antítese que reflete a ideia de pessoas como o homem anônimo do conto, que era belo, mas que tinha suas feições endurecidas, rudes, toscas. Esse povo mostra-se como um grupo que se constitui em suas fraquezas e em suas virtudes e é a motivação da poeta para a denúncia da situação de miséria em que os mais pobres se encontram. Assim como o homem do conto, "Estreitamente esculpida pela pobreza, a cara mostrava o belo desenho dos ossos" (ANDRESEN, 2010, p. 138), o povo tem seu rosto desenhado pela "paciência e pela fome". São uma gente moldada pela luta diária pela sobrevivência. Podemos também pensar no aspecto da reificação, da visão dessas pessoas já como coisas. A fome e a pobreza moldam as feições delas assim como um escultor modela uma madeira ou um pedaço de pedra.

Essa imagem é retomada na quinta estrofe, mostrando a gente "ignorada e pisada" em comparação com uma pedra, e ainda mais "Humilhada e calcada". "Coisificar" o homem é um mecanismo pelo qual a voz poética e a narradora do conto expressam o modo como a humanidade dessas pessoas é esmagada, relegada, ignorada, rejeitada pelos governantes, sobretudo considerando-se que Portugal, nos anos 1960, mantinha-se como uma nação essencialmente rural, com inúmeros focos de pobreza ao longo de seu território. A última estrofe rompe o silêncio ao qual essa gente é submetida e faz a denúncia do sofrimento e da miséria, trazendo uma visão positiva de esperança.

No conto, não temos, em princípio, o apelo de esperança que observamos no poema. O homem, morto, "continua ao nosso lado. Pelas ruas", a pobreza está por todos os lados, os miseráveis são ignorados, são escondidos pelo governo, são mascarados na 
paisagem. $\mathrm{O}$ homem pobre renasce sempre na medida em que as sociedades mantêm a exploração dos menos favorecidos privilegiando as classes mais abastadas. Ela é resultado do sistema econômico no qual estamos inseridos, e está presente desde sempre, mesmo em sistemas de outrora. Como observa Marx, "a exploração de uma parte da sociedade por outra é um fato comum a todos os séculos anteriores [ao capitalismo]" (2010, p. 57). Desse modo, o mendigo do conto existe, como sempre existiu em diversos contextos socioeconômicos. A história dele não se separa da história da pobreza, a sua morte não é o fim do problema.

Desse modo, ainda que a multidão passe sem perceber, ou sem querer perceber, a presença de homens como este existirá sempre, pois a miséria é inerente a um sistema que busca o lucro para poucos por meio da exploração de muitos. Haverá sempre o mendigo, como nos contos andresenianos, abandonados pelo governo, ignorados por seus semelhantes, sem voz, como ocorre em "O Jantar do Bispo", sem serem vistos, como em "O Homem". Mulheres como Palmira, de "Casa na Duna", que não conseguem se estabelecer por meio do seu árduo trabalho, também sobrevivem em tantas outras pessoas que tentam resistir com o pouco que possuem. Trabalhadores como Lobisomem, também de "Casa na Duna", cujo valor na sociedade é apenas a sua força de trabalho, continuam a existir na medida em que são explorados e animalizados pelas classes dominantes. Essa gente existirá desde que grupos abastados mantenham a situação de "existência servil” na sociedade, como observa Marx (2010, p. 50), seja criando condições de trabalho que não permitem a autonomia e a subsistência dos trabalhadores, seja promovendo o contexto de pauperismo crescente, marginalizando aqueles que, de certo modo, não conseguem se inserir por meio de sua atividade econômica. 


\section{Considerações finais: a ficção de Sophia Andresen e Carlos de Oliveira}

Todo escritor é filho de seu tempo.

Georg Lukács

Analisando os primeiros ${ }^{134}$ textos sobre estética de Georg Lukács, Nicolas Tertulian (1980, p.53) explica que, segundo o crítico húngaro, a "grande arte é sempre inspirada pelo sentimento de uma possível harmonia entre a interioridade e a exterioridade, entre a alma e o destino, entre as aspirações e a realidade do mundo objetivo" (nossa tradução). Assim, a arte tende a recompor o equilíbrio entre a subjetividade e a objetividade, oferecendo à alma depaysée ou exilada uma imagem do mundo, servindo-lhe de pátria ou de realidade "conforme a essência humana" (Ibid., p. 54, nossa tradução). Ainda jovem, o autor explorava o desaparecimento de um sentimento de unidade e coerência que ligaria o homem ao mundo real, uma espécie de metafisica, nas palavras de Tertulian (Ibid.), que o pensador encontrava no drama clássico ou em Shakespeare, por exemplo.

A complexidade da Modernidade, porém, teria destruído essa harmonia observada pelo jovem Lukács, “deixando ao indivíduo somente um papel de simples acessório, de peão subalterno entre as forças impessoais que o envolvem e o excedem” (Ibid.), criando uma condição humana subjugada pelo papel onipotente do capital e pelas massificantes instituições burguesas. Alguns autores observam que esse pensamento do Lukács inicial era, de certa forma, pessimista, mantendo relação com uma perspectiva hegeliana. Após seu contato com os textos de Karl Marx, o autor húngaro modifica um pouco sua concepção sobre arte, sobre o seu conteúdo e sua forma. No entanto, conserva um pensamento que nos parece muito eficaz para refletir sobre a ficção de Carlos de Oliveira e Sophia Andresen. Conforme Terry Eagleton explica, o Lukács marxista mantém a concepção de "os melhores artistas são aqueles que podem recuperar e recriar a harmoniosa totalidade da vida humana, fragmentada de modo crescente pela alienação capitalista" (1978, p. 45, tradução nossa).

De acordo com essa perspectiva, o artista ou o escritor consegue reunir "o geral e o particular [...] e o social e o individual dialeticamente em uma complexa totalidade" (EAGLETON, 1978, p. 45). Assim, o romance ou a ficção refletem de forma

\footnotetext{
134 O pensamento de Georg Lukács costuma ser dividido pela crítica em seus ensaios da juventude, antes do contato com a teoria marxiana, datado até 1918. Durante o último ano da Primeira Guerra Mundial, o pensador húngaro passa a dedicar-se ao estudo do marxismo, período em que ingressa no Partido Comunista.
} 
microscópica o complexo quadro dessa sociedade, combatendo a alienação e a fragmentação do contexto capitalista, projetando uma rica e multilateral imagem da totalidade humana, como explica Eagleton (EAGLETON, 1978, p. 45). É essa a concepção do pensador húngaro sobre "realismo", e uma obra considerada realista, para ele, apresenta uma "complexa e extensa série de relações entre o homem, a natureza e a história" (Ibid., p. 46, tradução nossa), criando uma forma de desvelamento das forças latentes de qualquer sociedade, desnudando a estrutura interna desta e sua dinâmica. Conforme analisa Eagleton, Lukács elabora a ideia de que

O trabalho de um escritor realista é dar vida às tendências [da sociedade] e às forças típicas em indivíduos e ações sensivelmente conscientes; ao fazê-lo desse modo, ele une o individual ao todo social e comunica cada detalhe concreto da vida social com o poder do "histórico-universal" - movimentos significativos da mesma história (Ibid., tradução nossa, grifo do autor).

As forças "típicas" referem-se às tendências não aparentes, mas presentes na sociedade, que levam a um movimento de discussão e reflexão sobre a organização capitalista burguesa, a qual fragmenta a totalidade da vida humana.

Ora, tal perspectiva nos auxilia a aproximar os romances analisados de Carlos de Oliveira dos contos de Sophia de Mello Breyner Andresen, verificando que cada autor, à sua maneira, promove em sua ficção uma espécie de desvelamento da sociedade que abordam e em que estão inseridos ao expor, por meio de sua escrita, as forças "típicas" a que se refere Lukács. Nas obras escolhidas, observamos um complexo quadro socioeconômico no qual se tecem relações de poder e de exploração de homens sobre seus semelhantes. Além disso, essas obras abrem um diálogo com o contexto cerceador e autoritarista em que ambos os poetas estavam inseridos, o Estado Novo salazarista. São textos que nos colocam diante de uma reflexão sensivelmente consciente de como os vínculos sociais se reproduzem através do poder do capital, relegando grandes grupos à "carência de quase tudo", como afirma Oliveira (2004b, p. 186).

Vimos, nos sete textos, uma articulação dialética entre o indivíduo e o todo concreto da sociedade, mostrando que aquele não pode ser lido sem considerarmos sua implicação no contexto sócio-histórico, o que promove ao leitor o contato com uma reflexão que busca desnudar esse amplo cenário e o leva a pensar sobre as estruturas e dinâmicas da sociedade de classes em um viés de "desalheamento", isto é, o desvelamento de como esses processos se instauram. Apesar disso, ainda que tais ficções insiram suas 
personagens em relação com o mundo real, não ocorre um apagamento de seus traços individualizantes, revelando homens e mulheres que, na sua individualidade, não podem se separar da história em que se inscrevem.

O termo "realista" suscitado por Lukács nos faz pensar - para além dos movimentos literários que utilizaram tal nome - a relação da obra de arte com a sua realidade. Nesse sentido, podemos considerar uma obra como "realista" porque se articula dialeticamente com o mundo real objetivo no qual está inserida. E, nesse aspecto, observamos ideias defendidas por Carlos de Oliveira e Sophia Andresen indicando que ambos estão, de certa forma, conectados ao contexto quando buscam elaborar seu projeto ficcional. Oliveira já diz, em seu "Almanaque Literário" (2004b, p. 65) que seu ponto de partida, como romancista, é a realidade que o cerca, buscando "equacioná-la em função do passado, do presente, do futuro; e noutro plano, em função de suas características nacionais ou locais" (Ibid.). Sophia, por sua vez, afirma que a sua poesia - e estendemos à sua prosa - é uma incessante busca do real, situação que a implica em sua realidade e a leva a procurar a relação justa entre o homem e seu mundo. Desse modo, os dois escritores - que apresentam nas obras lidas uma mundividência em diálogo com as teorias marxistas de classe e de exploração - concebem uma escrita em que o mundo real é matéria, forma e conteúdo. A complexa totalidade da realidade a que Lukács se refere é, de certa forma, o ponto de partida e de desenvolvimento para esses autores.

Tendo isso em mente, podemos verificar nos contos e nos romances lidos a tentativa dos escritores de criar a "forma microscópica" de uma ampla realidade, o que nos permite, como leitores, aproximarmos do crítico cenário da zona rural portuguesa e do modo como as estruturas sociais lá se organizam e se reproduzem. A Gândara, por exemplo, é-nos apresentada em toda sua agudeza, sendo desnudada palavra a palavra, conforme as estações do ano são apresentadas. Vimos homens sujeitos à aridez do verão e ao frio extremo da mesma maneira que estão subjugados ao poder de outros homens. Oliveira nos coloca diante da privação "de quase tudo" que tanto lhe marcou a infância. Essa precariedade é re-construída em Casa na Duna, partindo da complexa teia de relações entre camponeses, patrões e a natureza. Não é possível pensá-la isolada de cada um desses três fatores. A natureza impõe suas forças assim como o proprietário. $\mathrm{O}$ camponês, sem meios de proteção por causa da sua condição salarial, vê-se duplamente submetido. O autor, assim, revela o processo entrelaçado que forma essa peculiar realidade. De tal microcontexto, abre um diálogo com o amplo âmbito rural de outras regiões de seu país, onde a miséria assola com o mesmo peso e a mesma crueldade. 
Há ainda, nessa complexa totalidade, o elemento natural explorado através da animalização dos homens, como observamos em Lobisomem, visto antes de seu acidente como uma besta, um touro, pela sua imensa força, totalmente producente para o seu empregador e, depois, como um homem que já não se configura como indivíduo por não poder oferecer seu trabalho. É, então, como o meio lobo, meio homem, sugerido pelo seu apelido, zoomorfizado, comparado aos porcos, devido à sua sujeira. Por uma abordagem disfórica, o autor aproxima o ser do animal, indicando que, sem sua força de trabalho para vender, ele já não se pode definir como homem. A sociedade de classes, pautada na relação trabalho-capital, não o vê como indivíduo, e sua exclusão é marcada e simbolizada pelo seu caráter animalizante, um ser que somente come e bebe, sem nada produzir. A polarização entre classes, dessa maneira, passa pelo elemento natural, articulado diretamente ao contexto sócio-histórico e a função do homem nessa comunidade.

A relação entre o homem, a natureza e a história é ainda explorada em Pequenos Burgueses, onde o cenário da Gândara é retomado como um dos fatores de condicionamento do homem ao poder. Raimundo representa essa relação. Por um lado, seu caráter como humano é simbolizado pelo seu desejo, o que delineia sua subjetividade. No romance, estamos em contato com o lado subjetivo da personagem por meio dos seus sonhos e de suas reflexões acerca do seu anseio por um cavalo ou um animal no qual pudesse montar. Porém, esse desejo está vinculado ao contexto socioeconômico em que o homem coxo se insere. Seu sonho é negado pela sua condição de pobreza, isto é, pelo lugar que ocupa entre as camadas sociais. Assim, sua subjetividade não se separa do quadro sócio-histórico em que se encontra e, ainda que ele tenha um intenso desejo de ter um animal, sua posição inferiorizada nessa sociedade não lhe permite a sua realização, afinal falta-lhe algo que permita o poder de possuir: o capital.

A natureza funde-se ao homem através da profissão da personagem, um leitor de rastros. É na terra que Raimundo se encaixa como um ser útil à sociedade de classes, porém sua atuação é vista pelo seu caráter animalizante. Ele rasteja pelo solo como um animal, reconhecendo as marcas e as pegadas deixadas no barro instintivamente, sempre a farejar rastros. $\mathrm{Na}$ sociedade capitalista, que relaciona força de trabalho à individualização, como se o homem só pudesse ser reconhecido como tal se tiver uma utilidade dentro de seu contexto, a personagem aparece em seu modo mais rebaixada.

Mesmo o seu desejo - jamais atendido - revela a animalização. O que ele mais sonha é ter um cavalo ou uma égua, justamente para se locomover, pois é manco. Ora, o 
seu anseio é, na verdade, uma necessidade básica. Sendo um homem deficiente, ele precisa de um animal que lhe possibilite o deslocamento para assim poder exercer sua função. Neste aspecto, o caráter animalizante de Raimundo concilia-se à subjetividade de seu desejo: o seu sonho de ter um cavalo também expressa o desejo pela virilidade. Um homem velho, coxo e pobre não é visto por ser viril, pelo contrário, sua deficiência e sua idade colocam-no, no romance, diante de uma posição de quase mendicância, sendo relegado inclusive pela própria filha.

Sua imagem animalizada contrasta com a do Major - este, sim, viril, em sua imponente égua, cavalgando pelas suas terras e dormindo com a sua amante. O cavalo, desse modo, surge como um símbolo do vigor e da força, atributos negados a Raimundo, seja por sua condição física, seja por sua posição social. Sonhos são para os homens que podem pagar por eles, e a personagem não está em uma posição socioeconômica que lhe permita isso. Assim como um animal, motivado pelas suas demandas básicas e pelo seu instinto, Raimundo segue sua difícil vida a sonhar com uma égua, marginalizado e desumanizado por uma sociedade organizada pelo poder financeiro.

Sophia, cerca de vinte anos depois dos romances oliveirianos, retoma a elite rural para construir ela própria sua teia de relações sociais pautadas também pela antítese poder/miséria. Temos patrões e camponeses, ligados pela natureza - as chuvas que os afligem, a terra que os alimenta - e pelo capital. Novamente nos deparamos com uma tríade entre o homem, o capital e a natureza relacionadas à hierarquia do poder que subjuga e condiciona um grupo desfavorecido a outro abastado. Em "O Jantar do Bispo", porém, a natureza surge nessa articulação não por sua força imposta aos mais fracos, e sim por um viés mais contextual, o que não observamos em Oliveira. Enquanto o Bispo caminhava para sua difícil tarefa de pedir uma doação, sua mente, confusa, mostrava-se como o tempo, nebuloso. No conto, a angústia do Bispo intensifica-se na narrativa conforme percebemos que o céu está carregado de nuvens e escuro. A natureza conciliase à situação do homem, simbolizando a tensão que define o evento. A escuridão da noite potencializa, para o leitor, a apreensão da mente do pontífice na sua impossibilidade de ver a situação concreta, ou seja, que é parte de uma negociação determinada pelo poder sócio-histórico do capital. O Bispo seguia pela noite carregada enquanto ele mesmo estava em conflito, em uma espécie de conexão entre a natureza e o humano, formando uma complexa totalidade, se assim pudermos nos valer da expressão lukacsiana. O mundo real é, então, construído por meio de tais entrelaçamentos, revelando também a ligação 
entre o poder e a privação formada em torno da hierarquia, do capital e das classes socioeconômicas que ou subjugam, ou se sujeitam.

No conto seguinte, observamos novamente a presença da natureza como um fator que se relaciona às personagens e às situações vivenciadas. Há uma sutil oposição entre a natureza e o mundo artificial na narrativa de Lúcia. Sua vida antes de viver com a rica madrinha é descrita como quente, viva e livre. No dia do baile, a menina encontra-se no jardim, em contato com a grama e sentindo a leve brisa da noite, o que pode ser lido como uma analogia à sua vida até o momento. Porém, durante o evento, enquanto a vivacidade da noite e da brisa envolvem o cenário, ela é fortemente atraída pelo elemento artificial, isto é, a grande casa cor-de-rosa totalmente iluminada de onde saiam os barulhos da música.

A casa simboliza a camada favorecida economicamente, possivelmente a alta burguesia, observada pela então humilde menina que se encontra nos jardins. Esses elementos do mundo natural suscitam a ideia de liberdade da vida mais humilde da garota. A polarização histórica entre as classes é, assim, construída também pela breve associação com a natureza, que revela uma fidelidade da obra andreseniana "àquilo de mais puro, de mais verdadeiro, de mais antigo e de mais livre" (ROCHA, 1980, p. 16) que existe na realidade. Desse modo, a autora constrói também aquilo que Lukács chamou de complexa e extensa série de relações entre o homem, o contexto sócio-histórico e a natureza para abordar as relações sociais entre classes.

Através do trabalho analítico proposto neste trabalho, podemos observar, na leitura comparativa da prosa de Oliveira e Sophia, a ideia de Lukács, a partir de uma rigorosa leitura do mundo capitalista, uma busca pelo des-alheamento, a desalienação da obra literária, buscando um "estado de equilíbrio harmonioso entre as aspirações subjetivas e as exigências objetivas" do mundo concreto (TERTULIAN, 2008, p. 49), entre a "essência humana e a existência real" (Ibid.), considerando a implicação do homem, com seu caráter subjetivo, a um contexto concreto que lhe impõe as estruturas sócio-históricas. O realismo lukacsiano, seria, dessa forma, a expressão de uma exigência contra a alienação do sistema socioeconômico sobre o indivíduo (Ibid.). Ela resultaria de tal maneira que, na impressão imediata da obra de arte, a relação sujeito-objeto (subjetividade e objetividade) coincida em uma unidade espontânea, formando para o leitor um todo inseparável. O pensador húngaro vale-se da relação entre aspectos sociais - de natureza sócio-histórica - e a dimensão subjetiva e singular do homem para criar um 
modo crítico na obra literária que abranja a totalidade da vida humana (in: EAGLETON, 1978, p. 45).

Essa perspectiva nos leva a um dos elementos importantes na análise de uma obra considerada de temática social: o modo como as personagens são construídas. É muito recorrente a crítica defini-las como tipificadas, o que indica quase que imediatamente à característica de generalização, e o conteúdo crítico seria trabalhado através de tipos que representam o viés heterogêneo da sociedade. Lukács afirma que o ponto central de uma grande obra literária é o tipo, uma síntese peculiar que une organicamente o geral e o particular, ambos em personagens e situações (1964, p. 06). O que caracteriza um tipo não é sua qualidade de ser uma "média" de vários indivíduos, nem sua mera definição individual, mesmo que seja profundamente concebida. O tipo é formado pelos determinantes da essência humana e social em seu mais alto nível de complexidade e desenvolvimento, no seu último desdobramento de possibilidades latentes, mostrando como concreto "os picos e limites do homem e das épocas" (Ibid., nossa tradução), e as obras, assim, transcendem a literatura engajada. Para o pensador húngaro, a grande obra realista retrata o indivíduo e a sociedade como entidades completas, ao invés de mostrar um ou outro meramente em seus próprios aspectos. (Ibid.)

Em alguns romances neorrealistas, por exemplo, observa-se o destaque de algumas figuras somente para que elas "tipifiquem uma situação e um destino comuns", como observa Alexandre Torres, sem que haja um "processo de diferenciação excepcional em relação ao grupo" (2002, p. 217), o que ocorre no livro Gaibéus (1939), de Alves Redol. Desse modo, o herói do enredo é um grupo, destacando-se pela generalização da ação coletiva. Para esse autor, o importante não é o destino excepcional, e sim o modo como todos os gaibéus são explorados e, por isso, marginalizados socialmente.

Entretanto, ao analisarmos Casa na Duna e Pequenos Burgueses, observamos que, concomitantemente a um ideal de generalização, ocorre um processo de particularização das personagens devido a um aprofundamento psicológico trazido pelo escritor, o que seria, como aponta Torres, visto como um desvio do Neorrealismo ortodoxo. Mário Dionísio observa que o conceito de Oliveira de real e de objetivo compreende "o momento subjectivo" (apud TORRES, 1967, p. 250). Ora, mesmo que seu projeto ficcional busque estabelecer uma visão sobre a complexa realidade da sociedade de classes com o intuito de promover uma reflexão acerca desse quadro, o que 
lhe demanda abordar aspectos mais generalizantes, o autor particulariza suas personagens.

Podemos pensar, a título de exemplo, em Palmira, a empregada da casa dos Paulos em Casa na Duna. Ela representa o grupo menos favorecido, por meio do qual Oliveira aborda o insucesso da tentativa de ser uma microproprietária na Gândara, controlada pelos grandes patrões, o que a leva à emigração. Porém, na construção da personagem, temos alguns traços particularizantes. Seu principal desejo era casar-se, o que ela nutria em silêncio como um desejo singular. Quando alcança tal objetivo, torna-se dona de um pequeno pedaço de terra com o marido e passa a cuidar da lavoura e da sogra deficiente. Esse quadro, por um lado, explora o aspecto geral da camada dos pequenos proprietários, que se dedicam totalmente à sua pequena plantação, estando sujeitos às intempéries naturais e à quase impossibilidade de sobrevivência diante dos grandes terrenos produtivos. Ela lida com a situação com um misto de satisfação e resignação, o que pode ser lido na relação entre o âmbito geral e o particular. A resignação seria parte do aspecto generalizante, pois esse elemento constrói o fator de "alheamento" sobre o qual falamos no segundo capítulo. Já a satisfação pelo casamento - a despeito das dificuldades da nova vida - pode ser lida pelo viés subjetivo e, portanto, singular da personagem.

Em Pequenos Burgueses, também observamos o mesmo processo. Personagens como Raimundo e Cilinha ilustram a articulação entre o generalizante e o singular. Como vimos, a profissão do homem coxo era decifrar rastros no chão de terra e ler a sina das pessoas nas feiras da região de Fonterrada. A sua atividade concilia uma abordagem objetiva - verificar pegadas e traços no barro - a uma subjetiva e singularizante interpretar as linhas das mãos de seus clientes. Ele era o melhor leitor de rastros da região, algo que já o particulariza. Porém, seu trabalho o coloca em uma situação animalizante, o que aponta para um aspecto mais geral, isto é, ele representaria o trabalhador braçal, que exerce uma atividade inferiorizada pela sociedade de classes.

Por sua vez, Cilinha é descrita de forma generalizante como a filha de um homem autoritário e poderoso, o Major, mas vive, ao mesmo tempo em sua subjetividade. A descrição de seu ambiente, seu quarto, funde-se na narrativa da própria personagem, que vive uma paixão secreta pelo estrangeiro Pablo Flórez. Ela se encontra em um dilema, deve casar-se com o Delegado, mas ama outra pessoa. Nesse aspecto, temos o âmbito generalizante, dos casamentos arranjados entre famílias poderosas. Mas sua subjetividade é constantemente explorada pelo autor. Ela sonha, no capítulo VII, com uma disputa entre o futuro marido e o estrangeiro por sua pessoa. Pensa como seria ter uma relação sexual 
com o noivo prometido, mas surge-lhe à mente a figura de Flórez, marcando seu conflito. Cilinha, ao mesmo tempo que aparece como uma menina da elite alheia às situações de opressão e autoritarismo de seu pai e de sua classe, tem seu caráter psicológico aprofundado por meio da sua paixão secreta e seu desejo de liberdade.

No capítulo IX, ela tenta freneticamente capturar um pássaro azul que adentrou seu quarto. É impossível prendê-lo, então ela opta por bordá-lo, dizendo-lhe, no capítulo XVIII, que finalmente o apanhou. Nesse diálogo imaginário, temos uma dupla leitura, o aspecto mais aprofundado psicologicamente relaciona-se ao desejo de capturar o pássaro, tirando-lhe a liberdade que ela mesma não tem. Por outro lado, há o âmbito generalizante da menina rica alheia ao que se passa ao seu redor, voltada apenas para suas questões individuais. Carlos de Oliveira, desse modo, une o elemento geral ao singular com destreza, permitindo tanto que nos aproximemos subjetivamente de suas personagens como que conheçamos a sua posição social e, por vezes, o alheamento dela diante do complexo quadro das relações socioeconômicas.

Sophia Andresen também apresenta em seus contos uma relação articulada entre o geral e o particular de forma expressiva. Em Contos Exemplares, por exemplo, é comum o uso das alegorias para representar os tipos sociais, como acontece exatamente em " $\mathrm{O}$ Jantar do Bispo". As personagens não recebem nomes, como o Dono da Casa, que representa alegoricamente o rico proprietário da elite rural, como um terrateniente, de aparência nobre, de bom cristão. De forma tipificada, ele representa uma ordem naturalmente aceita na região. Sendo um fiel, não nega esmolas aos pobres, mas, ao mesmo tempo, define muito bem quem pode recebê-las ou não. Seu caráter alegórico está em representar concretamente alguns elementos abstratos, como a ambição, a necessidade de manutenção do poder, o desejo de se manter no controle. Ao mesmo tempo, é um tipo social - uma ideia de rico proprietário que poderia ser aplicada de forma generalizada aos grandes donos de terra da época em que Sophia escreve. Temos ainda o Homem Importante, uma alegoria de elementos negativos, de influências observadas por um ponto de vista disfórico, uma vez que ele representaria o Diabo, ou o mal. Desse modo, por meio da alegoria e da tipificação, a autora trabalha de forma muito significativa o aspecto geral do microcosmo que busca apresentar.

Ainda que a alegoria seja uma "superimagem" que representa um aspecto moral ou ideal, como analisa Antonio Candido (2006, p. 115), temos nas personagens do conto um aprofundamento subjetivo que reforça justamente a questão ética para a qual o texto aponta. O Dono da Casa, por exemplo, mesmo buscando manter a ordem naturalizada em 
que ele está no poder, pondera sobre seu pedido ao Bispo ao observar que o Pároco de Varzim era um oponente fraco, vestido em farrapos. Nessa breve subjetividade que a narradora indica da figura, vemos um ponto de vista que complementa o aspecto geral e conceitual do conto: o rico homem reconhece que a pobreza não é um adversário "à altura", uma vez que traz pessoas miseráveis sem condições de lutar, o que reforça o caráter negativo de fazer o pedido da remoção. O Padre da aldeia, por sua vez, também é elaborado através da articulação entre o geral e o particular. É uma alegoria do bem, da luta e da justiça, mas há traços que o singularizam, como o fato de ele vir de uma família nobre e abastada e abrir mão de sua herança e posição social para viver ao lado dos pobres. Essa informação particular reforça a alegoria do bem que ele concretiza.

O lado do bem é ainda centralizado na enigmática figura do mendigo - em princípio completamente generalizado, afinal era "como a gente de Varzim" (ANDRESEN, 2010, p. 75). Na realidade, ele não era apenas mais um pobre da aldeia, e sim um homem que acaba por promover uma mudança no pensamento do Bispo pelo seu ato de romper o silenciamento dos miseráveis e pedir a palavra. Mas era um homem misterioso, pois desapareceu sem explicações diante do pontífice e do seu chofer. O homem religioso, então, diz que viu Deus naquela noite. O mendigo era como todos os camponeses de Varzim, logo uma caracterização generalizante. Porém, ele se particulariza em romper a ordem de poder naturalizada e tentar falar com o rico proprietário. Ambos os elementos se completam para formar a aura misteriosa de tal figura. Deus seria visto assim no rosto miserável e cansado de toda gente pobre de Varzim. Mas essa compreensão se dá porque um deles se particulariza ao tentar uma ruptura da hierarquia social, criando uma relação entre o fenômeno da realidade concreta - as forças socioeconômicas de poder e subjugação - e o caso particular.

Podemos também observar com clareza a relação entre o geral e o particular na trajetória da menina Lúcia. Elaborado em oposições, o texto traz a singularização da menina antes pobre que observa desejosa o divertimento da classe favorecida. Em contraste, essa camada surge pelo aspecto generalizado nas duas ocasiões do baile. A superficialidade das conversas, as garotas que comentam a má aparência da garota humilde, as luzes e a música, que envolvem todos como se fossem uma unidade, e o jogo de aparências em que se tecem as relações sociais na grande casa cor-de-rosa. Lúcia, por sua vez, é representada por aspectos particulares, a exemplo da sua hesitação em morar com a tia enriquecida, pois perderia a vida viva, quente e livre da casa do pai. Ela é ainda singularizada tanto pela garota de vestido cor-de-rosa que lhe observa a beleza e a 
aconselha sobre os maus espelhos e as más pessoas quanto pelo seu par, o jovem que, a despeito do desprezo das outras meninas, convida-a para dançar. O rapaz e a garota de chiffon rosa particularizam Lúcia em um ambiente onde todos generalizam e tratam-se pela superficialidade, prezando as aparências.

Quando Lúcia opta em viver a "outra vida”, junto com a tia, ela passa a viver um conflito entre esse mundo generalizante e a sua singularidade, o que é concretizado em seu desejo de vingar-se da humilhação sofrida no passado. Ela quer ser parte do todo favorecido, mas guarda em seu passado a origem humilde, o que a envergonha e a leva a ter um colapso mortal. "A História da Gata Borralheira” também apresenta a articulação entre o geral e o particular no intuito de trazer uma crítica às classes abastadas e ao desejo de ascensão social a todo custo, o que é lido como um processo de "alheamento" ou, como Seixo se refere, "alienação" (1985, p. 94).

Temos, assim, em ambos os autores o processo de articulação entre aspectos generalizantes e particularizantes como parte da crítica social e denúncia que veiculam sobre as relações de classe pautadas no poder e na exploração dos menos favorecidos. Desse modo, não se apresentam somente "heróis coletivos", que representam uma classe em si, mas personagens singularizadas que expressam a reprodução do poder hierárquico e de classe de um grupo favorecido sobre outro subjugado, aprofundando a reflexão sobre o quadro sócio-histórico abordado e permitindo, ao mesmo tempo, um vínculo entre o leitor e as reflexões subjetivas das figuras elaboradas.

Em sua análise, Lukács observa que na grande obra a qual reflete a realidade, implicada em processos sócio-históricos, a "lei' (1966, p. 20) se revela como uma força motriz específica sobre o caso particular. Tanto Oliveira como Sophia abordam um contexto sócio-histórico muito próximo a eles em uma situação politicamente cerceadora e opressora, centralizada na figura de Salazar. Apesar disso, mesmo com uma diferença temporal ampla entre as narrativas lidas, os dois escritores dialogam com questões conceituais ligadas ao pensamento marxista por meio de um elaborado trabalho com a linguagem, distanciando seus textos de uma literatura engajada vista como superficial ou panfletária.

Em ambos, pudemos verificar uma aguda reflexão sobre o modo como as relações na sociedade de classe se estruturam, engendrando um quadro de exploração e desigualdade socioeconômica para a maioria da sociedade. Em Casa na Duna, Oliveira aborda o declínio da elite rural geracional inapta para se atualizar a um novo sistema econômico que chega e coloca o antigo poder familiar em questionamento. 
Paralelamente, o autor buscou trazer os reflexos desse domínio geracional por meio de personagens da classe desfavorecida, mostrando que, na verdade, sua análise é sobre o amplo quadro da zona gandaresa, e não um drama pessoal de um rico proprietário impossibilitado de manter seu poder, ideia lida por muitos críticos que acusaram o escritor de não elaborar uma obra neorrealista. O seu desvio de um Neorrealismo mais ortodoxo possibilitou uma grandeza de sua obra no âmbito conceitual, uma vez que ele conseguiu abordar a dinâmica das relações sociais, e não apenas falar das consequências a um grupo subjugado. É feita ainda uma análise de como o homem é visto somente como força de trabalho na relação patrão - empregado, o que reflete temas como a reificação do indivíduo numa sociedade pautada pela produtividade. O autor nos mostra que falar da exploração de modo crítico não é somente narrar a trajetória de vida dos explorados, mas, sim, analisar de que modo ela surge como consequência de um grupo abastado que luta pelo capital e pelo poder.

Sob tal perspectiva, podemos considerar a importância de Dr. Seabra como uma personagem que mobiliza aspectos sensíveis a uma visão mais conceitual da problemática abordada. É a partir dele que se comunicam na obra as consequências da "gerigonça social" (OLIVEIRA, 2004a, p. 72), termo usado pela própria personagem referindo-se ao modelo exploratório de trabalho de ganhões e jornaleiros submetido pelos grandes proprietários rurais. Conforme nos explica, sua reflexão política advém do fato de ter "um pouco de coração" (OLIVEIRA, 2004a, p. 73), o que aproxima uma abordagem subjetiva e individual à concepção de exploração da força de trabalho por ele criticada, algo do plano sócio-histórico. A denúncia das condições mínimas de sobrevivência dos camponeses baseia-se, como ele nos diz, em fatos - "Aponto simplesmente os factos, não indico nenhuma solução, não digo que o comunismo resolva ou deixe de resolver" (Ibid., p. 73-74). Dessa forma, o humanismo verificado em Dr. Seabra mostra o diálogo entre uma dimensão particular da personagem à situação de vida dos menos favorecidos e um posicionamento do plano contextual que o autor busca emitir em sua crítica.

Sophia Andresen, por sua vez, articula a influência desse pensamento a aspectos da sua mundividência pautada numa formação cristã em contato com conceitos do mundo clássico, como a harmonia e a justiça. Em "O Retrato de Mónica” essa relação aparece de forma clara quando a narradora descreve que a personagem "super-mulher" abriu mão da poesia e da santidade para poder ser aquilo que a alta sociedade espera de uma mulher. Ela nega a poesia e a santidade, mesmo que se dedique a um trabalho de caridade com outras mulheres de seu grupo. Sua caridade, ainda que seja necessária, não acompanhava 
a urgência da carência e da escassez das crianças pobres que receberiam suas roupas em crochê. Mónica estava em total descompasso com ideais de amor ao próximo e de compaixão pregados pela ideologia cristã. Sua caridade era como a do Dono da Casa, algo que lhes traziam uma boa imagem, mas muito aquém daquilo que eles realmente poderiam fazer dado o seu poder econômico. A poesia é também um elemento que pede uma análise mais profunda se considerarmos o projeto poético andreseniano, que contempla nesse conceito a relação do homem com o mundo, com os deuses e com a natureza. A poesia, assim, implica uma relação justa entre o homem, sua realidade e seus semelhantes. Implica também a justiça e a política. Mónica distancia-se desses elementos sendo a super-mulher de uma classe burguesa que busca sobretudo poder e influência. As relações existentes na sociedade que regem o sistema sócio-histórico mostram-se, assim, implicadas na pessoa de Mónica, que está cada vez mais resplandecente, bela e poderosa, enquanto as classes menos favorecidas seguem subjugadas e exploradas para dar poder, justamente, a esse grupo superiormente rico.

"O Jantar do Bispo" traz, como vimos, uma alegoria entre o mal e o bem lida na chave de conceitos sociológicos, como a polarização das classes. O humanismo cristão, que nos diz para amar ao próximo como se ama a Deus, despertou no pároco de Varzim uma consciência sobre a desigualdade social intensificada pelo seu contato com elementos de base marxista, trazendo ao texto alegórico uma tomada de consciência sobre o silenciamento dos mais pobres e daqueles que lutam por eles através do poder do capital. Assim, pudemos ver a classe subalterna explicitada entre os que tentam romper tal silêncio e os que assumem com resignação o lugar que lhes foi imposto socialmente, o que nos indica o alheamento de parte do grupo. Na tentativa de ruptura dessa condição, delineia-se a polarização entre as camadas sociais desse cenário.

Notamos a subjetividade também a partir da sensibilidade em Joana, a velha criada que se esquenta perto do fogo enquanto observa as tentativas do misterioso mendigo de falar com o Dono da Casa. Ela parece se compadecer dessa atitude, mas observa ligando-se a uma questão conceitual - que os pobres nunca são escutados. Ela ainda diz ao homem que, se não fosse tão velha, intercederia por ele. Nessa atitude, podemos ver uma espécie de compaixão, mas também uma percepção de seu lugar. Ora, como uma velha criada, Joana não está mais ativa, no sentido de não ser mais uma força de trabalho sob a perspectiva dos patrões. Assim, não pode comunicar ao Dono da Casa a demanda de um mendigo - ainda mais em uma ocasião especial como o jantar. Além disso, sua própria velhice parece ser um fator de restrição, talvez física, para que ela desempenhe 
tal ato. A compreensão da subjetividade nessa personagem articula-se a aspectos sociais tratados por Sophia Andresen, indicando uma consciência de hierarquização dentro de uma sociedade organizada pelo poder econômico da elite rural.

Outra personagem que nos chama a atenção em tal articulação é o menino João ${ }^{135}$, que tenta intervir pelo mendigo, porém sem sucesso. Ele apresenta um caráter sincero, algo que as crianças têm, pois, ao observar o Homem Importante, já emite sua opinião negativa sobre ele. João diz não gostar do homem, além de observar que este tem uma grande sombra, atitude que contrasta com aquela dos convidados, completamente atraídos pelo senhor importante e misterioso que surgiu durante o jantar. Talvez pela sua inocência, o menino ainda não possa distinguir o lugar dos pobres nas relações sociais, não compreendendo o porquê de ninguém ajudar o pobre homem a falar com seu pai. Ele representa, assim, uma ingenuidade que desperta a sensibilidade no leitor, rompendo a estrutura hierárquica e intercedendo pelo pobre de Varzim. Naturalmente, sua ação não resulta positivamente, pois o Dono da Casa não cede ao pedido do filho, mostrando, sob sua perspectiva, a inadequação de tal situação.

Já em “A História da Gata Borralheira”, observamos através da trajetória de Lúcia a articulação entre as relações sociais e a subjetividade da personagem. O ponto de mudança dela, quando aceita viver com a tia autoritária em nome da ascensão social, condensa justamente a mobilização do leitor diante da situação vexatória da menina humilde com o processo de alienação pelo qual passa ao optar por viver como a camada favorecida vive, perdendo tudo o que tem de real e natural em sua vida. A partir dessa ideia, podemos recuperar a etimologia de "alienar" do latim alieno, alienare, que traz como primeira acepção a ideia de "distanciar-se", "afastar-se"136. O termo ainda relaciona-se a forma aliênus, um adjetivo que significa "que pertence a outro, alheio, estranho". ${ }^{137}$ A ideia de "perda" e de "estranhamento" misturam-se etimologicamente nas acepções de alienação.

\footnotetext{
${ }^{135}$ É interessante notar que João, e seu feminino Joana por extensão, é um nome bíblico que pode se referir a João Batista e a João Evangelista, o discípulo de Jesus. De origem hebraica, tal nome pode significar "agraciado por Deus" ou ainda "Deus se mostrou misericordioso" (BEIDER, 2000; JACKSON). Ambas as personagens têm uma forte relação com Jesus segundo a bíblia. João Batista foi concebido por Isabel, mulher estéril, por intervenção divina, e ele se torna uma espécie de profeta, sendo para os cristãos, aquele que aponta para o verdadeiro messias, Jesus (Bíblia Sagrada, livro de Jó, 1; versículo 25). Já o discípulo João teria sido, conforme algumas interpretações da bíblia, o apóstolo amado de Jesus (Cf. CARSON, 2007; STONE; BERGREN, 1998.). O messias teria pedido a ele que cuidasse de Maria, sua mãe. Foi também batizado por João Batista, passando, assim, a esperar por Cristo. Nesse sentido, as duas figuras bíblicas apontam a noção de compaixão e misericórdia, o que é recuperado por Sophia ao atribuir tal nome justamente às duas personagens que se compadecem do pobre mendigo.

${ }^{136}$ Dicionário Escolar Latim-Português.

137 Dicionário Escolar Latim-Português.
} 
De fato, Lúcia ascende socialmente e passa a viver na esfera da grande casa corde-rosa. Porém, há a presença constante de seu passado que a incomoda, fazendo-lhe lembrar da humilhação sofrida, o que a mobiliza em relação ao seu desejo de ostentar sua posição social - que representaria, por sua vez, o próprio alheamento em que ela escolheu viver, pois é desse modo que a classe superior é retratada, relacionando-se superficialmente em um mundo de aparências. O conceito de alienação ${ }^{138}$ é parte essencial da teoria marxiana, sendo trazido simbolicamente por meio das ações de Lúcia, a qual é motivada pelos sentimentos de inferioridade e de vergonha e, em seu processo de ascensão, torna-se alheia à sua própria natureza, à sua origem, permitindo a reflexão do leitor sobre as relações de classe retratadas.

Tanto a prosa de Carlos de Oliveira quanto a de Sophia Andresen retratam as esferas do homem e da sociedade como parte de uma mesma articulação, de uma mesma unidade. A partir dessa relação, é elaborado também o processo de mobilização do leitor diante da desigualdade e injustiça relatadas. Na leitura dos contos e dos romances, somos levados à reflexão sobre os contextos elaborados - de exploração, miséria e opressão - o que é construído, em partes, pela dinâmica entre os conceitos de base marxista que baseiam a perspectiva dos autores trazida aos textos e os elementos subjetivos das personagens que também nos sensibilizam. Em ambos os escritores, o aspecto crítico unese a uma concepção de humanidade e de alteridade, pois o leitor é colocado à frente de um quadro em que homens vivem sem o mínimo necessário, subjugados e silenciados, levando-o, dessa forma, a compartilhar um sentimento de indignação. Mais do que isso, os textos promovem a análise de um cenário de desigualdade social que nos conduz a uma interpretação de des-alheamento e desnudamento das relações socioeconômicas tecidas na sociedade em que os autores estavam inseridos, pautada, por um lado, no poder centralizado de um governo ditatorial que mantinha as condições de miséria de grande parte da população e, por outro, na concentração de capital das elites - rural e a alta burguesia -, representando a riqueza social que submete e marginaliza a camada subalterna.

Podemos, dessa forma, observar em Carlos de Oliveira e Sophia Andresen o fato de expressarem em suas obras, como observa Lukács (1966, p. 21), as "premissas e condições do ser a partir das quais se origina e se desenvolve a consciência das

\footnotetext{
138 Como explicamos no capítulo 2, optamos, neste momento, por não nos aprofundarmos ainda no conceito de alienação, pois estamos estudando a sua complexidade para entender melhor como ele se relaciona aos textos lidos.
} 
personagens que representam" (nossa tradução). A visão de mundo oliveiriana, muito pautada nos primeiros romances na temática sócio-histórica, coaduna-se com o crescimento de personagens de modo singular, sendo que alguns, como Raimundo e Palmira, mantém-se alienados das estruturas socioeconômicas a que estão subjugados, e outros, como o Dr. Seabra, refletem uma perspectiva de maior consciência crítica em torno das regras que definem a sociedade capitalista. Já a mundividência andreseniana fortalece-se à medida que personagens como Lúcia e Mónica mostram-se também, de certo modo, alienadas no que tange à consciência de classe. Elas dedicam-se à manutenção do poder e da posição social, ao passo que milhares de pessoas ao seu redor sobrevivem com pouco, na "carência de quase tudo", como diz Oliveira.

Ambos os autores conseguem elaborar obras que trazem a totalidade da vida humana imbricada em seu contexto sócio-histórico, mostrando que a subjetividade é singular e, ao mesmo tempo, impregnada dos "contatos com a realidade objetiva" (TERTULIAN, 2003, p. 199), como Lukács procura demonstrar a realização de textos realistas. Além disso, Oliveira e Sophia desvinculam-se e deslocam-se dos movimentos literários em que surgiram. Sophia mostra-se uma autora ageracional, pois dialoga com preceitos dos Cadernos de Poesia, porém desenvolve seu projeto poético de forma coesa e consistente ao longo de suas obras, criando uma obra que exprime sua busca intensa pelo real e pela relação de equilíbrio entre homem, mundo e deuses.

A justiça perseguida em seus textos apresenta-se no seu olhar crítico sobre o mundo concreto, factível. "O Homem", o último conto analisado, indica a ciência da narradora diante do indivíduo miserável, enquanto as outras pessoas passam por ele e o ignoram, como se ele nada fosse, como se sua dor e desespero também não fossem parte do mundo em que eles vivem. Sua linguagem mantém-se clara e objetiva, uma constância em sua obra tanto poética quanto ficcional. O mundo trazido pela perspectiva de Sophia Andresen aos contos é o mundo da fratura, onde não há um equilíbrio justo entre o homem e seus semelhantes, o que é lido em seu diálogo com elementos do viés marxista, como o alheamento, a falta de consciência de classe e as imposições do mundo concreto à vida dos seres humanos mais carentes.

Carlos de Oliveira tem um percurso diferenciado, pois surge fortemente ligado à estética neorrealista, mas direciona e desenvolve sua obra para uma ruptura com esse movimento, como Finisterra nos mostrou. A linguagem poética, a tênue linha entre gêneros e a estrutura apresentadas nessa obra rompem de forma expressiva com os demais textos do Neorrealismo. A busca pela representação obsessiva do real das personagens 
insere um novo modo de se compreender o contexto - talvez o da Gândara - ao trazer alegorias e símbolos que abordam a condição da família retratada. A escrita de Finisterra e o constante trabalho do escritor em revisar sua obra considerada tão próxima do Neorrealismo levam-no a transcender a posição em que a crítica o insere, sem que ele, contudo, rompa com a temática social. O contraste entre questões universais do ser humano e elementos do mundo histórico e concreto fundem-se em sua narrativa final.

Ambos os autores enfatizam a busca pelo real em seus textos, mostrando aos seus leitores um viés de experiências de personagens singulares organizadas sobre regras sócio-históricas que condicionam o mundo concreto. Nas palavras de Lukács, em um mundo que se encontra despedaçado em "alienações" do capitalismo, o autor realista isto é, que busca trazer o real para a sua obra - é aquele que reúne dialeticamente os elementos da totalidade, sejam eles as lutas cotidianas, o caos, a pobreza, a exploração de homens por seus semelhantes ou um sistema que tem a subjugação como força motriz de seu pleno funcionamento. 


\section{Referências Bibliográficas}

Bibliografia Ativa - Carlos de Oliveira

OLIVEIRA, Carlos. Casa na Duna. Lisboa: Assírio \& Alvim, 2004a.

. “A Condição da Arte". In: Diário de Coimbra, XV, 18 mai 1945.

. Finisterra: paisagem e povoamento. Lisboa: Assírio \& Alvim, 2003a.

Mãe Pobre. Coimbra: Coimbra Editora, 1945.

. Pequenos Burgueses. Lisboa: Assírio \& Alvim, 2005.

. Pequenos Burgueses. 1a. ed. Coimbra: Coimbra Editorial, 1948.

. O Aprendiz de Feiticeiro. Lisboa: Assírio \& Alvim, 2004b.

. Trabalho Poético. Lisboa: Assírio \& Alvim, 2003 b.

Bibliografia Ativa - Sophia Andresen

ANDRESEN, Sophia de Mello Breyner. Contos Exemplares. 3. ed. Lisboa : Figueirinhas, 2010.

ANDRESEN, Sophia de Mello Breyner; SENA, Jorge de. Correspondência 1959-1978. Lisboa: Guerra \& Paz, 3. ed, 2010.

ANDRESEN, Sophia de Mello Breyner. Histórias da Terra e do Mar. 22. ed. Porto: Porto Editora, 2017.

ANDRESEN, Sophia de Mello Breyner. "Sophia de Mello Breyner Andresen fala a Eduardo Prado Coelho". In: ICALP - Revista, n. ${ }^{\circ}$ 6, p. 60-77, Agosto/Dezembro, 1986. Entrevista de Eduardo Prado Coelho e Lúcia Garcia Marques.

ANDRESEN, Sophia de Mello Breyner. "Sophia de Mello Breyner Andresen: 'Escrevemos poesia para não nos afogarmos no cais... "'. In: JL- Jornal de Letras, Artes e Ideias, Lisboa, $\mathrm{n}^{\circ}$ 26, p. 2-5, 16 fev. 1982. Entrevista concedida a Maria Armanda Passos.

ANDRESEN, Sophia de Mello Breyner. "Sophia: 'Sou uma mistura de Norte e Sul'. In: Jornal de Letras, 5 fev. 1985, pp. 2-3. Entrevista concedida a Miguel Serras Pereira. 
ANDRESEN, Sophia de Mello Breyner. Obra Poética. Edição de Carlos Mendes de Sousa. 2. ed. Alfragide: Editorial Caminho, 2011.

ANDRESEN, Sophia de Mello Breyner. "Poesia e Realidade". Colóquio - Revista de Artes e Letras, n. 08, 1960 p. 53-54.

ANDRESEN, Sophia de Mello Breyner. "Poesia e Revolução". In: ANDRESEN, Sophia de Mello Breyner. O Nome das Coisas. 1. ed. Lisboa: Moraes Editores, 1977, p. 77-80.

\section{$\underline{\text { Bibliografia Passiva }}$}

ABDALA JÚNIOR, Benjamin. A Escrita Neorrealista: análise socioestilística dos romances de Carlos de Oliveira e Graciliano Ramos. São Paulo: Ática, 1981.

ABDALA JÚNIOR, Benjamin. "Carlos de Oliveira: o intelectual, a política e a literatura”. In: Colóquio/Letras, 2017, mai/ago, n. 195, p. 105-116.

ABDALA JÚNIOR, Benjamin. De voos e ilhas: literatura e comunitarismos. São Paulo: Ateliê Editorial, 2003.

ABDALA JÚNIOR, Benjamin. Literatura, História e Política: literaturas de Língua Portuguesa no século XX. São Paulo: Ateliê Editoria, 2007.

Academia de Ciências da URSS. Manual de Economia Política. Academia de Ciências da URSS. Rio de Janeiro: Editorial Vitória, 1961. Disponível em:

https://www.marxists.org/portugues/tematica/livros/manual/index.htm. Acesso em 30 mai. 2016.

ALVES, Ida M. Santos Ferreira. Carlos de Oliveira e Nuno Júdice poetas: personagens da linguagem. Rio de Janeiro, 2000. Tese (Doutorado em Literatura Portuguesa) Faculdade de Letras, Universidade Federal do Rio de Janeiro.

ALVES, Jorge Fernandes. O furacão 'Delgado' e a ressaca eleitoral de 1958 no Porto. Porto: Centro Leonardo Coimbra / Faculdade de Letras da Universidade do Porto, 1998. Disponível em: http://ler.letras.up.pt/site/default.aspx?qry=id07id1174\&sum=sim. Acesso em: 01 mar. 2018.

ARAGÃO, Eloisa da Silva. Sophia de Mello Breyner Andresen: militância antifascista a partir da crise do Estado Novo (1958-1974), análise do conto "O Jantar do Bispo" e atuação da Assembleia Constituinte (1975-1976). São Paulo, 2017. 293f. Tese de Doutorado (História Social) - Faculdade de Filosofia, Letras e Ciências Humanas, Universidade de São Paulo.

ARISTÓTELES. Aristóteles. Coleção Os Pensadores. São Paulo: Nova Cultural, 2004. 
ARISTÓTELES. Ética a Nicômaco. In: Aristóteles. Coleção Os Pensadores. São Paulo: Nova Cultural, 1984 , p. 45-232

BAKHTIN, Mikhail. Marxismo e Filosofia da Linguagem: problemas fundamentais do Método Sociológico na Ciência da Linguagem. São Paulo: Hucitec, 1981. Trad. Michel Laud e Yara Frateschi Vieira.

BARTHES, Roland. Aula: aula inaugural da cadeira de Semiologia Literária do Colégio de França. São Paulo, Cultrix, 2004. Trad. Leyla Perrone-Moysés.

BARTHES, Roland. A Câmara Clara: nota sobre a fotografia. Rio de Janeiro: Ed. Nova Fronteira, 1984. (Trad.) Júlio Guimarães.

BAUDRILLARD, Jean. Simulacros e Simulação. Lisboa: Relógio d'Água, 1991. Trad. Maria João da Costa Pereira.

BEIDER, A. A Dictionary of Ashkenazic Given Names: Their Origins, Structure, Pronunciation, and Migrations. Teaneck: Avotaynu, 2000.

BELCHIOR, Maria de Lourdes. "Itinerário poético de Sophia". In: Colóquio-Letras, $\mathrm{n}^{\circ}$ 89, p.36-42, jan 1986.

BERGER, John. Way of Seeing. Londres: Penguin Books, 1972.

BETTElHeIM, Bruno. A Psicanálise dos Contos de Fadas. São Paulo: Paz e Terra, 2002.

Bíblia Sagrada Eletrônica. Disponível em: https://www.bibliaonline.com.br/. Acesso em fev 2018.

BOEHNER, Philotheus; GILSON, Etienne. História da Filosofia Cristã: desde as origens até Nicolau de Cusa. 8. Ed. Petrópolis: Vozes, 2003.

BOTTOMORE, Tom (edit). Dicionário do Pensamento Marxista. Rio de Janeiro: Editora Zahar, S/S. Disponível em:

http://sociologial.dominiotemporario.com/doc/DICIONARIO_DO_PENSAMENTO_M ARXISTA_TOM_BOTTOMORE.pdf. Acesso em 30 jan. 2018.

BOURDIEU, Pierre. "Gostos de classe e estilos de vida". In: ORTIZ, Renato (org.). A sociologia de Pierre Bourdieu. São Paulo: Ática, 1983.

BRANDÃO, Junito. Mitologia Grega. Petrópolis: Vozes, 1986, vol. 1.

CANDIDO, Antonio. Literatura e Sociedade. 13. Ed. Rio de Janeiro: Ouro sobre Azul, 2014.

CANDIDO, Antonio. O Estudo Analítico do Poema. São Paulo: Ed. Humanitas, 2006. 
CARLOS, Luís Adriano; FRIAS, Joana Matos (Dir.). Cadernos de Poesia. Porto: Campo das Letras, 2004.

CARLOS, Luís Adriano. "As últimas décadas: a geração dos Cadernos de Poesia. In: LOPES, Oscar; MARINHO Maria de Fátima (Dir.). História da Literatura Portuguesa: as correntes contemporâneas. Lisboa: Publicações Alfa, 2002, p. 235-267.

CARSON, D. A. O Comentário de João. São Paulo: Shedd Publicações, 2007. Trad. Daniel de Oliveira; Vivian Nunes do Amaral.

CASTRO, Sílvio. Poesia do Socialismo Português: no percurso de 1850 a 1974. Lisboa: Edições Colibri, 2010.

CHEVALIER, Jean. Diccionario de los Símbolos. Barcelona: Herder, 1986.

COELHO, Eduardo Prado. "Sophia, a lírica e a lógica". In: Revista Colóquio/Letras, n. ${ }^{\circ}$ 57, p. 20-35, set 1980.

COELHO, Jacinto Prado. "Contos exemplares". In: Colóquio - Revista de Artes e Letras, n. 58, p. 78, abril 1970.

Disponível em: http://coloquio.gulbenkian.pt/bib/cral/sirius.exe/artigo?1722. Acesso em 15 mai. 2018.

COELHO, Maria da Conceição; AZINHEIRA, Maria Teresa. Sophia de Mello Breyner Andresen: Histórias da Terra e do Mar. Mem Martins: Publicações Europa-América, 1995, col. “Apontamentos Europa-América Explicam”.

CORTINA, Adela. Aporofobia, el rechazo al pobre: un desafio para la democracia. Barcelona: Espasa Libros, 2017, versão e-book.

COSTA, Fernando Braga. Homens invisíveis: relatos de uma humilhação social. São Paulo: Globo, 2004.

COSTA, Fernando Braga . Moisés e Nilce: retratos biográficos de dois garis. Um estudo de psicologia social a partir de observação participante e entrevistas. São Paulo, 2008. 403f. Tese. (Psicologia Social e do Trabalho) - Universidade de São Paulo.

CROSARIOL, Isabelita Maria. "Um mundo dentro do mundo: um estudo de Finisterra, de Carlos de Oliveira". In: Anuário de Literatura, vol. 14, n. 1, 2009, pp. 62-73.

CRUZ, Manuel Braga da. "As Origens da Democracia Cristã em Portugal e o salazarismo". In: Análise Social, vol. XIV (54), 1978-2º, pp. 265-278

DIONÍSIO, Eduarda. "Pequenos Burgueses". In: Seara Nova, ano XLVIII, n. 1498, 1970. 
DIONÍSIO, Eduarda; FARIA, Almeida; MATOS, Luís Salgado de. Situação da Arte: inquérito junto de artistas e intelectuais portugueses. Publicações Europa-América, 1968.

DIONÍSIO, Mário. "Prefácio". In: OLIVEIRA, Carlos de. Casa na Duna. 3. ed. Lisboa: Portugália, 1964.

DUARTE, Gonçalo. O Trágico em Graciliano Ramos e em Carlos de Oliveira. Coimbra: Angelus Novus, 2008.

DUARTE, Lélia Parreira. "Fingimento Reduplicado e Valorização da Alteridade: Pequenos Burgueses, de Carlos de Oliveira. In: Itinerários - Revista de Literatura, n. 12. Araraquara, 1998.

EAGLETON, Terry. Literatura y Crítica Marxista. Bilbao: Zero Ed., 1978.

EAGLETON, Terry. Marxismo e Crítica Literária. São Paulo: Editora UNESP, 2011.

EIRAS, Pedro. "Minério, Gisandra, Wasteland. Carlos de Oliveira e o Fim do Mundo". In: eLyra, n. 03, mar 2014, pp. 113-123.

ENGELS, Friedrich. A Origem da Família, da Propriedade e do Estado. Lisboa: Editorial Presença, s/d.

FLETCHER, Angus. Alegoría: teoría de un modo simbólico. Madri: Ediciones Akal, 2002. Disponível em:

https://books.google.pt/books?id=Us06VOHFN_kC\&printsec=frontcover\&hl=ptBR\&source=gbs_ge_summary_r\#v=onepage\&q\&f=false. Acesso em: 20 dez. 2018.

FRANZ. Marie Louise von. The Interpretation of Fairy Tales. Colorado: Shambala Public. Versão Eletrônica. Disponível em: file:///C:/Users/natha/Downloads/MarieLouise\%20von\%20Franz,\%20Kendra\%20Crossen\%20-

\%20The\%20Interpretation\%20of\%20Fairy\%20Tales\%20(1996,\%20Shambhala).epub.

Acesso em: 10 mar. 2018.

FERREIRA, Armando Ventura. "A propósito do último livro de Alves Redol”. In: Seara Nova, n. 962, 1946.

GANDOLFI, Leonardo. Mundo Comum e Povoamento da Paisagem - ler com "O Aprendiz de Feiticeiro" de Carlos de Oliveira. Niterói, 2007. 120 f. Dissertação (Mestrado em Literatura Portuguesa e Africana) - Instituto de Letras, Universidade Federal Fluminense.

GANDOLFI, Leonardo. Entre Carlos de Oliveira e João Cabral de Melo Neto - Errar a Paisagem. Niterói, 2012. 238 f. Tese (Doutorado em Literatura Comparada) - Instituto de Letras, Universidade Federal Fluminense. 
GRAMSCI, Antonio. 1978. Concepção dialética da história. Rio de Janeiro: Civilização Brasileira.

GUimarẽes, Fernando. A poesia da Presença e o aparecimento do Neorrealismo. Porto: Editorial Inova, 1969.

GUSMÃO, Manuel. A poesia de Carlos de Oliveira. Lisboa: Seara Nova/ Editorial Comunicação, 1981.

GUSMÃO, Manuel. Finisterra - o trabalho do fim: recitar a origem. Coimbra : Angelus Novus, 2009.

HESÍODO. Teogonia. Estudo e Tradução Jaa TORRANO. São Paulo: Iluminuras, 2007.

HUTCHEON, Linda. Narcissistic Narrative: the metafictional paradox. Ontário: 1980.

INWOOD, Michael. Dicionário Heidegger. Rio de Janeiro: Jorge Zahar Ed., 2002. (Trad.) Luísa Buarque de Holanda.

JACKSON, J. B. A Dictionary Of the Proper Names of the Old and New Testament Scriptures, being and Accurate and Literal Translation from the Original Tongues. Disponível em:

http://www.gracegod.com/pamphlet_and_articles/articles/A\%20Dictionary\%200f\%20t he $\% 20$ Proper $\% 20$ Names $\% 20$ of $\% 20$ the $\% 2001$ d $\% 20$ and $\% 20 \mathrm{New} \% 20 \mathrm{Testament} \% 20 \mathrm{Scr}$ iptures\%20by\%20J.\%20B.\%20Jackson.pdf. Acesso em 16 abr. 2018.

JAEGER, Werner. Paideia: a formação do Homem Grego. 3. ed. São Paulo: Martins Fontes, 1995. Trad. Artur M. Parreira.

LANCIANI, Giulia. "Sophia de Mello Breyner Andresen: o labirinto da palavra". In: Colóquio/Letras, n. 176, jan/abr 2011, pp. 09-14.

LEPECKI, Maria Lúcia. Sobreimpressões: estudos de Literatura Portuguesa e Africana. Lisboa: Editorial Caminho, 1988.

LOPES, Oscar; MARINHO, Maria de Fátima (Dir.). História da Literatura Portuguesa: as correntes contemporâneas. Lisboa: Publicações Alfa, 2002, vol. 7.

LOURENÇO, Eduardo. "Para um retrato de Sophia". In: ANDRESEN, S. M. B. Antologia. 4. ed. Lisboa: Moraes, 1975.

LOURENÇO, Eduardo. "Presença ou a Contrarrevolução do Modernismo Português". In: LOURENÇO, Eduardo. Tempo e Poesia. Lisboa: Relógio d'Água Editores, 1987, pp. 143-168.

LOURENÇO, Eduardo. Sentido e Forma da Poesia Neorrealista. Lisboa: Gradiva, 2007. 
LOURENÇO, Eduardo. "Dez anos de Literatura Portuguesa (1974-1984): literatura e revolução". In: Revista Colóquio/Letras, n. 78, mar 1984, pp. 07-16.

LUKÁCS, Georg. Studies in European Realism. Nova York: The Universal Library, 1964.

LUKÁCS, Georg. Ensaios Sobre Literatura. Rio de Janeiro: Ed. Civilização Brasileira, 1965.

LUKÁCS, Georg. Problemas del Realismo. México: Fondo de Cultura Económica, 1966.

LUKÁCS, Georg. Estetica. Barcelona: Ediciones Grijalbo, 1967.

LUKÁCS, Georg. Realismo Crítico Hoje. Brasília: Coordenada-Editora de Brasília, 1969.

LUKÁCS, Georg. História e Consciência de Classe: estudos sobre a dialética marxista. São Paulo: Martins Fontes, 2012. Trad. Maria Ermantina Prado.

MACEDO, Joana Marques. "Os movimentos Modernista e Neorrealista e o debate sobre a Arte pela Arte e a Arte Social. In: Sapiens: História, Património e Arqueologia. [versão digital]. N. ${ }^{\circ}$ 3/4 (Dez. 2010), p. 125-151.

Disponível em:

http://www.revistasapiens.org/Biblioteca/numero3_4/os_movimentos_modernista_e_ne orealista_e_o_debate_sobre_a_arte_pela_arte_e_a_arte_social.pdf. Acesso em: 05 jun. 2017.

MACHADO, Álvaro M (Org. e dir.). Dicionário de Literatura Portuguesa. Lisboa: Presença, 1996.

MALHEIRO, Helena. O Enigma de Sophia: da sombra à claridade. Alfragide: Oficina do Livro, 2008.

MARTELO, Rosa Maria. A Construção do mundo na poesia de Carlos de Oliveira. Porto, 1996. Tese (Doutorado em Literatura Portuguesa) - Faculdade de Letras, Universidade do Porto, Portugal.

MARTELO, Rosa Maria. A Forma Informe: leituras de poesia. Lisboa: Assírio \& Alvim, 2010.

MARTELO, Rosa Maria. "Casas Destruídas: a revisitação de Casa na Duna em Finisterra de Carlos de Oliveira. In: Línguas e Literaturas. Porto, XVII, 2000, pp. 251260. 
MARTINS, Conceição Andrade. "Trabalho e Condições de Vida em Portugal (18501913)”. In: Análise Social, vol. XXXII, 1997, pp. 483-535.

MARX; Karl; ENGELS, Friedrich. Manifesto Comunista. São Paulo: Boitempo Ed., 2005. Org. e introd. Osvaldo Coggiola.

MARX, Karl. Teorias da Mais-Valia. História Crítica do Pensamento Econômico. São Paulo: Difel, 1983, vol II. In: NETTO, José Paulo; BRAZ, Marcelo. Economia Política: uma introdução crítica. São Paulo: Cortez, 2006.

MARX, Karl. Manuscritos Económicos-Filosóficos. Lisboa: Edições 70, 2017.

MARX, Karl. O Capital. Livro 1. São Paulo: Boitempo Ed., 2011. Trad. Rubens Enderle.

MATTOSO, José. “A Formação da Nacionalidade”. In: TENGARRINHA, José (Org.). História de Portugal. Bauru: EDUSC; São Paulo: UNESP; Lisboa: Instituto Camões, 2. ed, 2000, pp. 07-18.

MEDEIROS, Nuno. "Action, Reaction and Protest by Publishers in 1960s Portugal: Books and Other Publications in the Catholic Opposition. In: Politics, Religion \& Ideology, vol 16, 2015, pp. 137-153. Disponível em: http://dx.doi.org/10.1080/21567689.2015.1059762. Acesso em: 12 mar. 2018.

MIGUEIS, José Rodrigues. "Panorama Literário Português". In: Diário de Lisboa, 22 mar. 1935, p. 06 (suplemento literário). Disponível em:

http://www.fmsoares.pt/aeb_online/visualizador.php?bd=IMPRENSA\&nome_da_pasta $=05760.024 .05685 \&$ numero_da_pagina=14 . Acesso em: 13 jun. 2017.

MOURÃO, Luís. Um Romance de Impoder: a paragem da história na ficção portuguesa contemporânea. Braga/Coimbra: Angelus Novus, 1996.

NAHAS, Nathália Macri. Grades: uma leitura do projeto po-ético de Sophia de Mello Breyner Andresen. São Paulo, 2015. Dissertação (Mestrado em Literatura Portuguesa) Faculdade de Filosofia, Letras e Ciências Humanas, Universidade de São Paulo.

NETTO, José Paulo; BRAZ, Marcelo. Economia Política: uma introdução crítica. São Paulo: Cortez, 2006.

PAIXÃO, Fernando. "Poema em prosa: problemática (in)definição". In: Revista Brasileira, n. 75, fase VIII, abr-jun 2013, pp. 151-162. Disponível em: http://www.academia.org.br/abl/media/Revista\%20Brasileira\%2075\%20-

\%20EDITORIAL.pdf. Acesso em 01 nov. 2018.

PEREIRA, António; FIGUEIREDO, Cecília de. Histórias da Terra e do Mar de Sophia de Mello Breyner Andresen. Lisboa: Texto Editora, 1999. 
PESSOA, Fernando. Páginas Íntimas e de Auto-Interpretação. Textos estabelecidos e prefaciados por Georg Rudolf Lind e Jacinto do Prado Coelho. Lisboa: Ática, 1966.

POMA, Paola. "Sophia e as coisas do mundo". In: Revista Ângulo. Lorena (SP), no 125 126, set 2011, pp. 106-109.

POMA, Paola. “As Várias Faces da Gata Borralheira”. Literatura Portuguesa - ontem, hoje. São Paulo: Ed. Paulistana, 2008, pp. 219-230.

REIS, Carlos; LOURENÇO, António Apolinário. História Crítica da Literatura Portuguesa. V. 08, Lisboa: Editora Babel, 2015.

REIS, Carlos (Apres. crítica). Textos Teóricos do Neorrealismo. Lisboa: Seara Nova / Editorial Comunicação, 1981.

REIS, Jaime. "A industrialização num país de desenvolvimento lento e tardio: Portugal, 1870-1913”. In: Análise Social, vol. XXIII (96), 1987, pp. 207-227. Disponível em: http://analisesocial.ics.ul.pt/documentos/1223486204E9wNP8ed3Ez05AO7.pdf. Acesso em: 13 mar. 2018.

ROCHA, Clara Crabbé. Os 'Contos Exemplares' de Sophia de Mello Breyner. Coimbra: Instituto Nacional de Investigação Científica, 1980.

ROCHA, Clara Crabbé. “Andresen, S.M.B.”. In: MACHADO, Álvaro M (Org. e dir.). Dicionário de Literatura Portuguesa. Lisboa: Presença, 1996, p. 36-38.

RICARDO, D. Princípios de Economia Política e Tributação. São Paulo: Abril Cultural, 1982. [apud] NETTO, José Paulo; BRAZ, Marcelo. Economia Política: uma introdução crítica. São Paulo: Cortez, 2006.

SANTILlI, Maria Aparecida. Arte e Representação da Realidade no Romance Português Contemporâneo. São Paulo: Edições Quíron, 1979.

SCHUBERT, Kurt. Os partidos religiosos da época Neotestamentária. 2 ed. São Paulo: Paulinas, 1979.

SEIXO, Maria Alzira. "Recensão Crítica a Histórias da Terra e do Mar, de Sophia de Mello Breyner Andresen. In: Revista Colóquio/Letras, n. 87, set 1985, pp. 92-94.

SEIXO, Maria Alzira. A Palavra do Romance: ensaios de genealogia e análise. Lisboa: Livros Horizonte, 1986.

SILVA, Manuel Carlos. "Camponeses nortenhos: «conservadorismo» ou estratégias de sobrevivência, mobilidade e resistência?” In: Análise Social, vol. 23, n. 97, 1987, pp. 407-445. 
SILVESTRE. Osvaldo Manuel. Slow Motion. Carlos de Oliveira e a PósModernidade. Braga/Coimbra: Angelus Novus, 1994.

SILVESTRE. Osvaldo Manuel. "Carlos de Oliveira por Eduardo Lourenço e Óscar Lopes, nos idos de 40 e 50: notas filológico-críticas”. In: Primeira Mão, 2001, pp. 341354. Disponível em: http://www.osvaldomanuelsilvestre.com/publicacoes/. Acesso em: 02 nov. 2017.

SILVESTRE. Osvaldo Manuel (Org.). Depois do Fim: nos 33 anos de Finisterra. Paisagem e Povoamento. Coimbra: Centro de Literatura Portuguesa, 2011.

SILVESTRE. Osvaldo Manuel. "A Poesia Póstuma de Carlos de Oliveira”. In: Revista Colóquio/Letras, 2017, mai/ago, n. 195, pp. 09-33.

SOARES, Maria Luísa Castro. Considerações Gerais sobre a Literatura Tradicional de Transmissao Oral: uma proposta de análise à versão portuguesa de "A Gata Borralheira" (Consiglieri Pedroso). Vila Real: Universidade de Trás-os-Montes e Alto Douro, 2009, col. "Didática", n. 41.

SONTAG, Susan. Sobre Fotografia. São Paulo: Cia das Letras, 2004.

SPIVAK, Gayatri Chakravorty. The Post-Colonial Critic: interviews, strategies, dialogues. Londres: Routledge, 1990.

SPIVAK, Gayatri Chakravorty. Pode o Subalterno Falar?. Belo Horizonte: Editora UFMG, 2010. Pref. de Sandra Regina Goulart de Almeida. Trad. de Sandra Regina Goulart de Almeida, Marcos Pereira Feitosa e André Pereira Feitosa.

STONE, Michael E.; BERGREN, Theodore. Biblical Figures Outside the Bible. Pensilvânia: Trinity Press International, 1998.

SULEIMAN, Susan Rubin. Authoritarian Fictions: the ideological novel as a literary genre. Nova Jersey: Princeton University Press, 1993.

TERTULIAN, Nicolas. Georges Lukács: etapes de la pensée esthétique. Paris : Le Sycomore, 1980.

TERTULIAN, Nicolas. Georg Lukács: etapas de seu pensamento estético. São Paulo: Editora Unesp, 2008.

TORGAL, Luís Reis. Estados Novos: Estado Novo. Coimbra: Imprensa da Universidade de Coimbra, 2009.

TORGAL, Luís Reis. "O Estado Novo. Salazarismo, Fascismo e Europa. In: TENGARRINHA, José (Org.). História de Portugal. Bauru: EDUSC; São Paulo: UNESP; Lisboa: Instituto Camões, 2. ed, 2001, p. 391-415. 
TORRES, Alexandre Pinheiro. O Movimento Neorrealista em Portugal na sua Primeira Fase. Lisboa: Instituto de Cultura e Língua Portuguesa, 1983.

TORRES, Alexandre Pinheiro. "Neorrealismo". In: LOPES, Oscar; MARINHO, Maria de Fátima (Dir.). História da Literatura Portuguesa: as correntes contemporâneas. Lisboa: Publicações Alfa, 2002, vol. 7, p. 183-233.

TORRES, Alexandre Pinheiro. Romance: o mundo em equação. Santa Maria de Lamas: Portugália, 1967. 